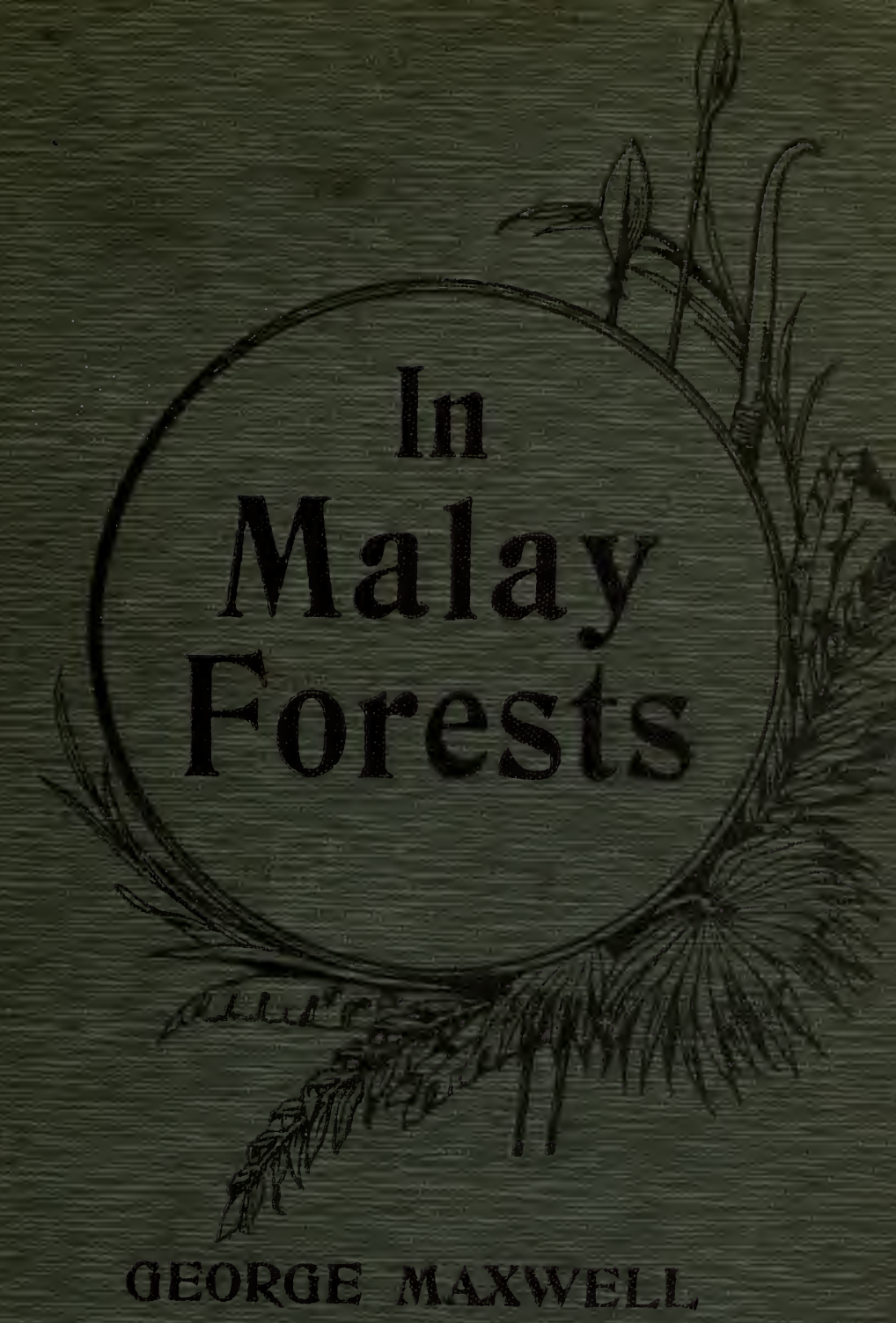


Digitized by the Internet Archive in 2007 with funding from

- Microsoft Corporation

http://www.archive.org/details/malayforestsin00maxwrich 


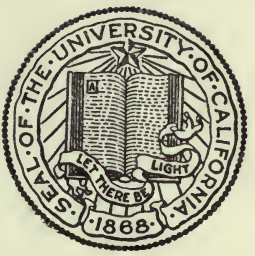

THE LIBRARY OF

\section{THE UNIVERSITY} OF CALIFORNIA

PRESENTED BY

PROF. CHARLES A. KOFOID AND MRS. PRUDENCE W. KOFOID 




\section{In Malay Forests}





\section{In Malay Forests}

BY

\section{GEORGE MAXWELL}

SECOND EDITION

WILLIAM BLACKWOOD AND SONS EDINBURGH AND LONDON M C M X I 

$S^{\prime} K 247$

$\mathrm{M} 27 \mathrm{Mz}$

1911

TO

OMY WIFE 



\section{P R E F.A C E.}

Six of the articles in this volume have appeared before, and for permission to reprint them my thanks are due to the editors of 'Blackwood's,' 'The Pall Mall,' 'Macmillan's,' and 'Temple Bar.'

The first article is intended to be an introduction to, or setting for, the others, regarding which I need say no more than that they are accounts of personal incidents, and they range through different States of the Malay Peninsula, and cover many years.

\section{GEORGE MAXWELL.}

\footnotetext{
Penang,

January 1907.
} 



\section{O N T E N T' S.}

PAGE

THE FOREST

THE PINJIH RHINO

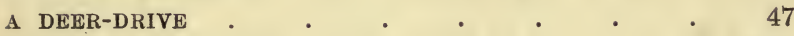

CROCODILE CATCHING . . . . . . . . 66

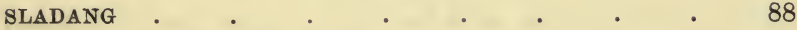

THE LIGHTS OF CHANGKAT ASAH . . . . 109

TAPIR $\quad . \quad . \quad . \quad . \quad . \quad . \quad . \quad . \quad 125$

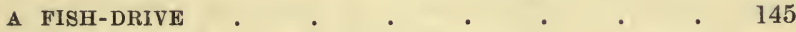

THE WILD GOAT . $\quad$. . . . 167

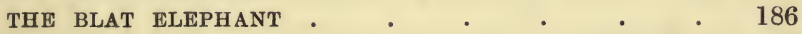

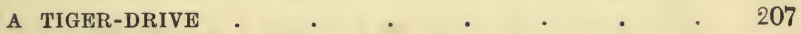

A TALE BY THE WAYSIDE . . . . . 225

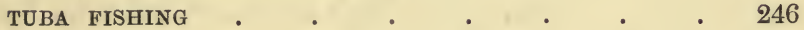

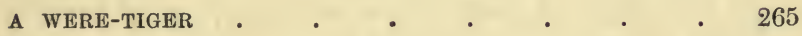

CROCODILE SHOOTING . . . . . . 280

APPENDIX I. : THE PAWANG . . . . . 298

II II. : THE MANTRAS . . . . 307 


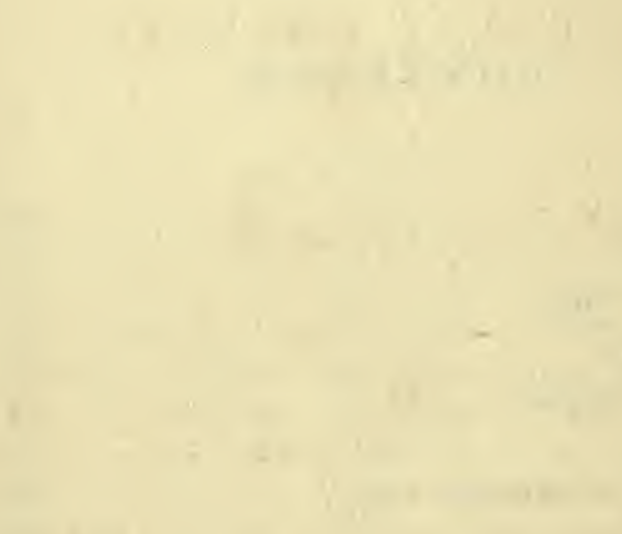




\section{IN MALAY FORESTS.}

\section{THE FOREST.}

To most people the Malay Peninsula is only known as the long narrow strip that, on the map of Asia, runs down into the sea beyond the bulky V-shaped projection of India, and divides the Indian Ocean from the China Sea.

Passengers by the mail-boats for the Far East, though they approach it at the islands of Penang and Singapore, see of its length during their voyage down the warm smooth waters of the Straits of Malacca but little save a continuous range of distant mountains bathed in a haze of purple, blue, and grey.

He whose business or pleasure takes him on one of the local steamers sees a little more. In the foreground there is, on the west coast, an unbroken line, level as that of the sea, of dark-green forest. This is the mangrove belt, which grows on the alluvial soil brought down and silted up by the rivers, and which ends where the sea begins. Behind this line rises a range of heavily-timbered mountains, and behind this 
yet another range; and on all sides the horizon is bounded either by forest-covered mountains or by forest-covered plains.

It is almost the literal truth that the whole peninsula is covered with forest. It is not that the country is uninhabited, for it has a population of some hundreds of thousands : but it is that the inhabited area, every yard of which has been won from, and hacked out of the forest, is infinitesimal in comparison with the extent of the forest that remains untouched.

Throughout its hundreds of miles of length and breadth the Malay Peninsula is practically one vast forest. The great alluvial tin-fields of Kinta, Larut, Selangor, and Seremban, where tens of thousands of Chinese coolies strip the surface to lay bare the ore, are really mere patches; and the towns, palatial and magnificent though the buildings of some of them are, are nothing more than specks in an expanse that sweeps from one Sultanate to another, and is only limited by the sea.

Our railways and roads run through forest, and our mines, plantations, and towns are bounded by it.

It is, however, difficult at first to realise the environment of the forest. When the newcomer has left his steamer, and the railway has taken him to the town which is his destination, it is possible that he may fail to appreciate the most wonderful of all the new sights around him; he may, and most frequently does, accept the dense mass of trees and vegetation that shuts in the railway line as "the jungle," and consider the timber-clad mountains merely in the light of scenery. In a Malay village one may better realise the manner 
in which the forest hems in the cultivated area. The settlement is generally situated on the banks of a river. By the water's edge are the houses, built under the shade of fruit-trees, and behind them are the flat, irrigated padi-fields. On all sides this area is shut in by a dark heavy line that uprears itself, around and above it, like the walls of a prison. This line is the forest edge; and thence the forest spreads in every direction, miles upon miles, until some other village is reached; there it opens out again, and sweeping round the clearing, as a wave encircles some ocean rock, closes in again behind it and continues, over mountains, over plains, until the sea is reached.

But it is when he views it from a mountain peak that the stranger can best see the extent of the forest. He will then discover, what the Malay can never for a minute forget, that he lives his life in the midst of a forest which is as much apart from him as it is around him. The fact that it extends, interminable, far beyond the horizon on every side, then for the first time makes its indelible impression upon his mind.

This other wonderful thing he will perhaps first realise : the forest is an evergreen; the season, whose changes in the cultivated area turn brown soil to the tender green of the young padi shoots, to the richness of the colour of the swelling plants, and to the golden wealth of the ripened grain, fails to touch the forest. Neither the season, nor the flight of time, leaves a mark upon the forest ; virgin in the days of which we cannot guess the morn, virgin in our days, virgin it will remain in the days of generations yet unborn.

On the slopes of the nearest spur each individual 
tree stands clear, each giant form showing the swelling roundness of its wealth of bough and leaf. Tier upon tier, the trees stand thickly massed, without a break, from the level of the plain to the height of the topmost trees that show their heads against the sky-line. Deep, dark, sombre green is the colour of this near range; here and there one may catch glimpses of lighter shades, a few scattered patches perhaps of sage green where some trees, after fruiting, are putting forth a new flush of leaves; possibly there may be a speck of vivid red that marks a tree whose young shoots assume an unusual colour. But the contrast only accentuates the prevailing tone.

Beyond these hills, which are not perhaps more than a few miles away, rises a range that is clad in purple. At this distance the mass of trees shows through the clear atmosphere, not with the shape of each individual tree, but with a uniform raised and rounded roughness that covers alike mountain crag and mountain ravine.

In some places in the plains between the two ranges one may perhaps see the lighter green that marks a cultivated area, or a gleam of white sand where alluvial tin-mines show like islands in the sea.

Beyond the purple mountains rise other ranges, and though, of course, you cannot see it, you know that the forest sweeps on through wide hidden valleys and wonderful places rarely trodden by man, until it reappears in sight upon another range.

The mountain-chains melt from purple to blue, and as they recede the roughness of the forest covering becomes a velvety pile, and then an even softer 
texture; and finally, where grey mists melt and dissolve in the distant haze, it is not easy to know which is forest and which is sky.

Such is the view that lies beneath your eyes as you stand upon a mountain peak some four or five thousand feet above the plain. But so deep, so soft is the mantle of forest, that you may fail to realise the grandeur of the mountans. They have not the austerity that belongs to nakedness. To right and to left, where the mountain spurs run out and down to the plain, your eyes rest on slopes which, though steep perhaps, are softly undulating. Each tree melts gently into its neighbour, or partly hides it; all is green and harmonious, and the mountain offers a face which appears to be as smooth and unbroken as a pasture land. But sometimes you may see how deceptive this appearance is. It has been raining, and a great cloud comes slowly swimming landward from the sea. The direction that it takes will bring it within a mile of you. As it approaches the mountain you wonder what will happen,-whether it will rest against the mountain-side, or whether it will roll upwards through the trees. But to your amazement, when the cloud edge touches the mountain it does not stop. Then you see that the whole cloud is swimming on into the mountain. What has happened is that a mountain ravine has acted as the channel up which a current of air is rushing skywards from the plain, and into the ravine the cloud is being slowly sucked. As the cloud enters, its shape and size and colour help your eye to see both sides of the ravine, and you may vaguely estimate the depth and 
width of the valley that had been strangely invisible although so close. But as soon as the cloud is past and gone, the trees on both sides of the ravine seem to leap together; and, though you now know exactly where to look, waving branches and woven leaves defy your efforts to say where the entrance is. You then wonder how many similar places are hidden around you, and picture to yourself the great sea cloud hemmed in by the sides of the ravine and still swimming further landward.

There is another time when you may have a revelation. A few minutes after sunset the westward facing mountains blaze with the refulgent glory of an afterglow. A rosy light probes the secrets that the forest hides from the noonday sun-the grandeur of wide valleys that wind an intricate way into the inmost heart of the mountains; the mystery of little deeplyshaded tributaries that fall into them on either side; the vastness of untrodden ravines and gorges; the majesty of unscaleable precipices; the terror of long straight scars that tell of landslides where trees and soil and rock have slipped in hideous disaster, leaving a wound that has cut to the very bone. For a moment all is revealed-the mantle of forest does not avail against this searching light, and you may well think that it is in the sweet exposure that the mountains blush.

But come down from the mountain peak, and walk alone along a forest path. Though it is midday it is very dark and very sombre. The sun cannot pierce the dense foliage of the branches of the giant trees, and so heavily do shadows lie upon shadows that the 
very green seems almost black. The sheltered air is fresh and cool, and there is an almost perfect stillness. Underfoot, except where the path is trodden bare, is a matting of dead leaves and of sweet damp moss. The track upon which you stand is a foot or perhaps a foot and a half wide, and at the height of your body the width of the open way is perhaps three feet. The daily passage of the Malays keeps back the encroachment of brambles and forest creepers. But the track is only wide enough and the opening only high enough to allow a man to pass. You could not ride even the smallest and handiest of ponies along it.

To right and left of the path the forest appears to be almost impenetrable. The trees grow so thickly together that you are closed in by a small but unbroken circle of tree-trunks. Between the trees there are tangled masses of bushes, briers, and saplings. Rattans and creepers of every kind crawl along the ground and among the trees, sometimes hanging in heavy festoons and sometimes tense with the pressure that they exert. So thick and strong is the mass of creepers that when a wood-cutter has hacked through a tree-trunk it is often kept upright by the ligaments that bind it to the surrounding trees. After an hour's walk along a forest path, a casual observer might say that, so far as he could see, the forest contained no flowers, no butterflies, no birds, no life of any kind. But if you sit upon a fallen tree-trunk and look around, you may see a little more. High in a tree, and almost out of sight, you may see an occasional flower, and lower down perhaps, your eye may light upon an inconspicuous spray of blossoms that a care- 
ful scrutiny shows to be a miniature orchid. There are few butterflies in the forest, but now and then, if you are by one of the openings among the trees, which are to the winged creatures what the paths are to us, you may see a moth or butterfly pass by flapping its heavy velvet wings. You seldom hear a bird, but if you are quiet and wait long enough some tiny sunbird may come your way, or, perhaps, some weird bird with light-blue eyes and an enormous tail; or a junglehen may creep out from under a bush, and scratch for ants' eggs in an open space where a tree has fallen. The only other thing that you will see, except an occasional lizard, will be ants, and perhaps a millepede. If you know where to look for them, you will see the tracks of four-footed animals, but you will not see the animals themselves.

But in a forest which you know to be so vast and so boundless you have a right to expect more than you have seen. Ants, a butterfly, even a bird, do not and cannot represent the life of this great gloomy place. But more you cannot see. You are the centre of a small circle whose radius varies from fifteen to thirty yards. Inside this circle you can see more or less distinctly; outside it everything is hidden. Even so huge an animal as an elephant is sometimes invisible at fifteen yards, and almost always invisible at thirty yards. Wherever you go you carry with you that little circle outside which lies the unknown. The path that lies behind you is, as soon as it passes outside that circle, as full of the unknown as the path before you or the tangle on either side. So little do you see that the feeling comes over 
you that you are alone in the midst of mysterious, hidden things. The feeling that immediately follows this is that these mysterious things are not merely hidden, but are specially hidden from you. The circle that moves with you is the veil built up against you. You could imagine that you were a trespasser, or at all events were regarded as such. Then you have the horrible feeling that from behind the tree-trunks watching eyes are looking upon you. It is bad enough at any time if you are alone and all is quiet; it is worse as the sun sinks and light fades; it is worst if by any ill chance you happen to know that you have lost not only your way but your sense of direction.

At all times you may see things happen of which the reason is hard to divine. Though not a breath of air can be felt to move, a frond of a palm may begin to sway gently and rhythmically backwards and forwards while all the other fronds of the same tree remain as motionless as the trees around. You examine the palm to see if there is possibly a rat or some other animal at its base, but can discover nothing. Sometimes one single leaf amidst the numbers on a branch may begin without apparent cause to be violently agitated, and will as suddenly stop.

The Malays always consider themselves as intruders when they enter the forest, and never forget their awe of and reverence for it. They seldom go into the forest alone; and when one man asks another to accompany him, the reason that he is going into the forest is always considered to be 
sufficient in itself. While it is true that the forest lies almost at their doors, they never forget not merely that no man knows its 'extent, but that it actually is without bound or limit.

To the Malays the great enveloping forest is full of supernatural powers. There are the wonderful Jin Tanah, the Earth Spirits; Gergasi, the great tusked giants; Orang Bunyi, the invisible Voice Folk. There are individual creatures-such as Hantu Pemburu, the Spectral Hunter; mountain-top and river pool have their local spirits; and there are classes innumerable of ghosts, goblins, and demons.

They are known as Hantu Hutan - the Spirits of the Forest,-and are as real to the Malays and as much dreaded as the tigers and other wild animals of the forest.

Men, such as rattan-cutters or gutta-hunters, whose vocations take them into the forest, repeat a short charm to avert the wrath or displeasure of these spirits; and the farther they go from home the more careful are they to make use of due ceremony and incantation.

The forest envelops their homes and their lives; but, as with the fisherfolk and the sea, the more they explore it the more they know that it is a world apart. That it is so near and extends so far adds to it majesty and terror. In order to realise something of what the Malay forest is, one may perhaps look at it for a moment from the point of view of the Malays, who know it better than any one else. And in the charms, which have been handed down from generation to generation, and which the Malays 
repeat to this day when they enter the forest, one may have some perception of the sentiment that inspires them. A rattan-cutter, though he may find plenty of canes within easy call of his home, repeats this invocation to the spirits of the forest-

"Peace ${ }^{1}$ unto ye all!

I come as a friend, not as an enemy.

I come to seek my living, not to make war.

May no harm come to me, nor mine,

To my wife, my children, or my home.

Because I intend no harm, nor evil,

I ask that I may come, and go, in peace.

It is worthy of notice that, though the Malays have been staunch Muhammadans for centuries, their aboriginal fear of the forest is so deeply rooted that it is to the spirits and not to Allah that they apply for protection.

Similarly, when a party of Malays sets out to drive deer, the commonest of all game, they may go no more than a few hundred yards away from the village; but none the less the leader of the party will utter this preface to his prayer to the spirits-

\section{"Hail! All hail !}

We crave permission to enter on this domain And to tie our nooses to these trees."

1 The original Malay of the various invocations quoted in these pages will be found in the Appendix. 


\section{THE PINJIH RHINO.}

An old rhinoceros, that made its abode in the Pinjih valley in the Kinta district, was for many years the most famous animal in the native State of Perak.

In the first place, it was kramat: that is to say, the Malays credited it with supernatural powers, and imagined it to be protected against all danger by a guardian spirit. It often happens that an animal which attaches itself to one locality and establishes a reputation for daring or cunning, and which is fortunate enough to escape a few ill-directed bullets, comes in a few years to be considered kramat, and is in many cases imagined to be a reincarnation of a deceased celebrity. It is generally recognised that animals under the protection of another world will treat the human inhabitants of the district honoured by their presence with a benign consideration bordering on condescension; thus a kramat elephant will walk by the rice-fields leaving the crops untouched, and a child might drive away a kramat tiger that strayed too near the cattle-folds.

But this rhinoceros was extraordinarily savage; and it was this combination of kramat power and 
savagery that constituted its second claim to distinction. It was known to have killed three men on three separate occasions, and in each case the attack was said to have been entirely unprovoked. At an inquest held on the terribly mangled body of a Malay named Japaringonen, the evidence proved that two men had been walking quietly along a forest path when, without any warning, the great brute had rushed upon them. In many other cases men had been attacked, but had escaped with their lives. It would turn aside for no one, so it was said; on the contrary, if met in the forest, it would either stand its ground and then slowly and deliberately advance in the direction from which it had been disturbed, or it would charge without warning.

It had been a terror in the Pinjih valley long before the British occupation of Perak (1874), and twenty-five years later, at the time of this narrative, it was only in large and armed parties that the wood-cutters and rattan-collectors ventured into the less frequented parts of the forest.

On more than one occasion the headman of the district had organised expeditions to kill the animal, and once a party of five picked Malays had met the rhinoceros and had fired fifty shots at it. I heard the headman tell the story once. "It was no child's play," the old man said, turning fiercely on one of an audience who had criticised the shooting. "If a bullet felled the brute, it picked itself up at once; and if a shot missed, it charged forthwith. A hundred men might have fired more shots, but they could not have done more to kill it. And," he added with 
a scowl, "the end of the matter is, that you cannot kill an animal that will not die."

The animal's third claim to distinction lay in its horn, which was said to be of exceptional length and girth, and also to be blue. Malays divide rhinoceroses into four classes, according to their horns. There is the one known as sumbu lilin, the "waxcoloured horn"; sumbu api, "the flame-coloured horn"; sumbu nila, "the blue horn"; and lastly, sumbu itam, the ordinary everyday "black horn."

Rhinoceros' horns are considered to have the most marvellous efficacy as remedies for almost every kind of disease, and even shavings of a horn are carefully prized. In a case where the most appalling wounds were inflicted by this particular rhinoceros upon a man named Kanda Daud, the whole credit of the man's recovery was ascribed to the alleged fact that some of the blue of the animal's horn had come off on the man's hands as he sought to defend himself, and that this blue had been used by the native doctors as the antidote to the wounds.

The fact that made this rhinoceros so well known among the Europeans of Kinta was not so much the colour of its horn, or that it was kramat, or was savage, as that it was of the large one-horned variety known as Rhinoceros Sondaicus, which is somewhat rare, and that it seldom left an area of some forty square miles, circumscribed by bridle-paths, and within close reach of the headquarters of the district. By comparison with the boundless extent of the forest on all sides, and with the roving propensities of most big-game animals, this made it easily accessible; and 
many efforts were made to bring it to account. But (partly on account of the native trackers being afraid to bring their men up to the brute) something always went wrong. Once the District Magistrate managed to get on terms with it, but was charged so often and so determinedly in very thick scrub that he had to beat a retreat and leave the rhinoceros master of the field. In the dull record of failures there was, however, one light spot. The attendant spirit of kramat animals has power to deceive the hunter by altering the appearance of the hunted animal or by giving its shape to one of the hunters or their attendants, and on one occasion a gallant officer in the $\mathrm{N}$ Regiment fell its victim. Leaving his pad elephant in the forest with a Malay in charge, he proceeded one day to set off on foot to look for fresh tracks. He walked for hours, until suddenly his tracker stopped him and silently pointed out the outline of a huge animal in front of them. M. took a steady aim and fired: a scream from a sorely-stricken elephant and a yell from a terrified Malay were his answer. He had walked in a circle and had fired at his own elephant. As the smoke cleared he caught a glimpse of the elephant rushing madly through the forest and had a full view of the Malay bellowing on the ground. The wretched man had been quietly smoking his cigarette on the elephant's neck, and now, lying where he fell was only in doubt whether a bullet-wound or a broken neck was the cause of his death. Both elephant and man recovered, the Malay the quicker of the two, for the elephant, though the wound healed, was never fit for work again; but both had a lucky escape, for the 
bullet, which hit the elephant high on the shoulder, had gone perilously near the man's leg. It will be some time before $M$. hears the last of the shot; but the chaff of the clubs does not carry the bite of the smiles of the Malays, who give the credit of the whole occurrence to "old kramat" and his guardian spirit.

Such, briefly, was the history of the animal, and Malias was by no means keen on tackling him. Malias was a local Malay who drew a regular salary from me, and who wandered round the country seeking for, and as far as possible verifying, news of game. He was not particularly bright, and, like all Malays, was inclined to be lazy; on fresh tracks, however, he was as keen as possible, and he would follow up a wounded tiger without his pulse giving a stroke above its normal beat. Chance brought us an ally: this was an old man named $\mathrm{Pa}$ ' Senik, a foreigner from one of the northern unprotected States. He was of another type to Malias, who was a mere villager; for $\mathrm{Pa}^{\prime}$ Senik's youth had been spent at the court of a petty raja, and had been such as might be expected from his surroundings, full of conspiracy and intrigue, love and lust, fair fight and cold-blooded murder. At last he had fallen upon bad days, for another raja ruled in the place of the man he had served, and he had had to fly for his life. He came to Perak, where he was shrewdly suspected of complicity in a carefully planned and well-executed dacoity, and then settled down quietly in the Pinjih valley, where until his eyesight failed him he had 
made a living by shooting deer. He was now old and poor, but despite his age was keen to go after the rhinoceros, and, knowing its haunts and wallows, assured us that he could bring me up with it. But this was no ordinary quest, he said; if without preliminary preparations we went in search of tracks, we were foredoomed to the failure that had attended all previous efforts. We must first "ask" for the rhinoceros from the Jin Tanah, or Earth Spirits, who have power over the forest and all its inhabitants, and to whom the attendant spirits of kramat animals are vassals. $\mathrm{Pa}$ ' Senik, who was a pawang, ${ }^{1}$ proposed to make a feast and invoke the spirits, and to ask them to give us the rhinoceros and to accept compensation. We should not have to pay much, he said, for the spirit, if it accepted the offer, would probably ask for something to eat, a fowl perhaps, or some eggs, and a lime or two. Of course, if the spirits proved obdurate, nothing could be done, and we must not think of any act of defiance; but, if made with skill and address, our application would, he thought, be favourably considered. The exchange value of a rhinoceros in the spirit world seemed to be extremely moderate, and I gave the old man a dollar (all he asked for) with which to prepare the feast preliminary to the invocation, and arranged to go to his house to witness the ceremony.

The following Saturday was the day agreed upon,

1 A pâwăng is a man who, by ceremony, incantation, or charm, propitiates or invokes the assistance of the spirits. He figures in every enterprise and festival of the Malay community. For a fuller account see the Appendix. 
and a few miles by railway to the next station, and a walk of a couple of miles took me to his village, where a house has been set aside for me. After dinner I was invited into the adjoining house, where Pa' Senik had made his preparations. Like all Malay houses it was divided into three parts: the front room or verandah, absolutely public; the middle room, where the men eat and sleep, reserved for intimates; and the kitchen, where the unmarried women sleep, absolutely private. The ceremony was to take place in the centre room, and here I was introduced to Che Mat, a brother pawang, whom $\mathrm{Pa}^{\prime}$ Senik had called in to assist him. After a few minutes' conversation the proceedings began, and while they sat down and faced one another over a brass bowl containing burning charcoal, I made myself as comfortable as I could upon the floor within a few feet of them, and round us such men and women and children as had obtained admission ranged themselves in a semicircle. 'Various bowls of water, in which floated leaves and flowers, were set about the flour, and twigs and sprays of leaves and blossoms were fixed to the posts and walls. Each bowl and leaf and flower had its definite significance, and to each were spells and charms attached. $\mathrm{Pa}$ ' Senik then took up an arbab, a three-stringed instrument, in shape somewhat like a banjo, but played with a bow. After a tentative essay or two he struck up a monotonous chant to a tune a degree more monotonous. Much of his music was improvised to meet the special conditions of the present instance; but the greater portion of it was part of 
his traditional craft. It was lengthy and full of repetitions: but the gist of it was that here was a white man, who came to ask the assistance of the spirits; and here were Malias, Che Mat, and $\mathrm{Pa}^{\prime}$ Senik, the servants and followers of the white man, and they too craved the assistance of the spirits; and in the forest was the rhinoceros whom they desired to take, and whom they now besought the spirits to give them. What answer would the spirits give us, and by what means could we ensure their assistance in the enterprise? Such, in a few words, was the meaning of an invocation that lasted twenty minutes. The chant ended, Pa' Senik laid aside his bow, and asked one of the company to recite from the Koran. A man at once began to intone some verses, while the whole audience joined in the usual responses and replies, and the protection of the Islam religion was thus called in upon proceedings utterly at variance with the teaching of Muhammad. When this was over, a tray containing rice and various kinds of curry was brought up to Che Mat, who had hitherto remained silent and motionless, in pose of entire abstraction. He now roused himself, and throwing some gum benjamin into the censer over which he faced $\mathrm{Pa}$ ' Senik, moved the tray in and out of the thick smoke until it was thoroughly fumigated. Then he took a saucer of rice from an attendant, and passed it in a similar manner through the smoke, and after placing a lighted candle on the edge of the saucer, put it on a tray suspended from the roof between the two men. Finally, a plate of parched rice was 
purified from all mortal taint by smoke, and then, also with a lighted candle on its rim, carried out of the house by Che Mat, and hung on a tree. ' $i_{2}{ }_{-}$' marked the conclusion of the opening stage of the proceedings. The rice on the tray between the two men was of a peculiar kind, considered a delicacy, which is used in sweetmeats, and was intended to attract the attention of the spirits we desired to invoke. The parched rice outside the house was for any of the thousand and one wandering demons who might appear, and who, unless thus provided for, might mar the proceedings. The curry and rice was for the audience, most of whom at once followed it to a corner of the room, and devoted an undivided attention to it.

After an interval both men stripped to the waist, and $\mathrm{Pa}$ ' Senik took up his instrument, and to the same drear chant reiterated the purpose for which we met. Che Mat in the meantime undoing the handkerchief that Malays bind round their heads, let a mass of long hair fall down upon his shoulders, and carefully combed it out and anointed it with cocoanut-oil. He then bound his handkerchief round the long glistening hair, and rolled it scarf-wise round his head. When this' was done he brought forward more saucers of rice, and held them in the smoke of the censer, and passed his hands, his head, his breast, his knees, and his back through the pungent incense, ending by moving the censer three times round himself. He bowed to the four cardinal points, took some of the rice in his hand, and, muttering a spell over it, blew upon it in the pro- 
fessional manner known as jampi. Another candle was lit, and $\mathrm{Pa}^{\prime}$ Senik again began to play his instrument. Suddenly Che Mat broke in upon the monotonous music of the arbab, clapped his hands wildly above his head, shook his hair free from the handkerchief that bound it round his forehead, and, with a quick twist of his neck, swung his long locks in a sweeping circle round his head. The suddenness of the interruption was startling. Round whirled the black glistening mane, followed by the gaze of every eye in the room, and as it completed the circle, another short jerk of the muscles of the neck sent it again madly flying round his head. Again and again, and more quickly each succeeding time, was the stream made to revolve round him, until at last all that was to be seen of the man seated on the floor was his short bare body, with an occasional glimpse of white compressed features, surmounted by a black, rushing, whirling halo that filled and fanned the room. For some minutes this extraordinary muscular effort continued, until suddenly Che Mat fell forward in a state of collapse. There was perfect silence for a few moments, while all the spectators held their breath, and then $\mathrm{Pa}^{\prime}$ Senik, picking, up some rice, threw it over the supine figure, and asked him who he was. There was no answer, and $\mathrm{Pa}$ ' Senik was forced to have recourse to his arbab. After a considerable interval Che Mat announced that he was Pran Ali, meaning thereby that he was possessed by a spirit of that name. In answer to questions put by $\mathrm{Pa}^{\prime}$ Senik, the spirit Pran Ali expressed himself as friendly to us, and a 
natural enemy of the earth spirits and the guardian spirits, but declared that he was unable to help us in the quest of the rhinoceros; deer were the animals over which he had power, not rhinoceroses. If it had been a deer now-

Pran Ali could help us no further, and thereupon left, and Che Mat was no longer possessed of him. There was another interval of singing and playing by $\mathrm{Pa}$ ' Senik, who called on various spirits to come to our assistance, and repeated innumerable charms to prevent the rhinoceros from hearing or scenting us as we approached it, to prevent it from charging, or from recovering from any wound that might be inflicted upon it. "If all the dead return to life and walk this world again, then, and not till then, may this animal turn upon us; if the bottommost of the three layers of stone that support the earth reappear upon the surface, then, and not till then, may this animal attack us." But to repeat one-tenth of the incantations and invocations would fill many pages, and would interest but very few. Che Mat stopped the long tale by again evincing signs of another demoniacal possession. Again his attitude of abstraction fell from him, and his weird hair-swinging held the room. After the pause that followed his collapse he inquired what we wanted of him, and when Pa' Senik offered him a bowl of parched rice, he at once seized it and swallowed a handful of the contents; when a plantain was produced, he gulped it, skin and all, and then announced that he was Sang Kala Raja Megang Rimba, one of the guardian spirits. $\mathrm{Pa}$ ' Senik thereupon humbly inquired whether we 
might be allowed to follow the rhinoceros (which, by the way, was throughout the evening spoken of as a buffalo), and the spirit's immediate reply was a downright refusal, saying that on no account would he lose the animal. This caused a sensation amongst the audience, and there was much shaking of heads, but $\mathrm{Pa}$ ' Senik was not to be beaten. He began with cajolery, and when that had no effect tried what is vulgarly known as bounce. Who was this spirit that he should take this defiant attitude? To this the spirit answered that he was a thousand years old: $\mathrm{Pa}^{\prime}$ Senik declared that he was a thousand years older. "Ten thousand years old," replied the spirit. "Ten thousand years older," retorted $\mathrm{Pa}^{\prime}$ Senik, who thereupon challenged his adversary to a contest as to which was the stronger. When the challenge was accepted, $\mathrm{Pa}$ ' Senik seized a handful of parched rice and threw it full in the face of his adversary, and then leant forward, glaring at him over the smouldering censer. His opponent immediately seized a huge bowl of rice and raised it in the act to hurl ; but when his arm reached the topmost point above his shoulder from which it would turn to throw, he suddenly stiffened, and the whole of his body became rigid. For a few seconds he sat there living and motionless as the statue of a discobolus: and then the bowl dropped from his nerveless fingers and fell crashing to the floor. Sang Kala Raja Megang Rimba was beaten in contest. He cast himself forth, and Che Mat was thrown into a third frenzy, becoming possessed of a spirit named Awang Mahat. Unfortunately Awang Mahat be- 
longs to that unhappy class, whether in this world or the other, of creatures who mean well: his intentions are excellent, but he is powerless for good or evil, and the consideration he meets with is, therefore, such as might be expected. Little was asked of him, and he could tell us less: beyond saying that if our quarry were wounded near water it would come to life again (a pleasing prospect, as we had to seek it in swamp and marsh), he could not help us. He remained but a few minutes, and then craved leave to depart. When he left, Che Mat was nearly fainting, and to allow him to recover there was a long interval of playing and singing by Pa' Senik. Che Mat's wife, herself no unskilled disciple in witchcraft, in the meantime occupied herself in attending to her husband, breathing upon him, rubbing, kneading, and massaging him. When attention was called and the proceedings resumed, Che Mat fell into a fourth frenzy, more violent than any that had preceded it. $\mathrm{He}$ had undergone his previous attacks in silence, but this time he gave vent to scream after scream, short sharp yells of pain. When the succeeding exhaustion had somewhat passed, he declared that he was the Jin Kepala Gunong Api-the Jin of the Volcano's Summitone of the Jin Tanah, the Earth Spirits, whom we had to fear in this enterprise. He was most violent at first, but soon became quiet, and then friendly, and finally asked what we would give him if he allowed us to "take" the rhinoceros. Various gifts were suggested, but rejected as valueless in the Spirit World, until finally the offer of an egg, some 
parched rice, and the rice I have mentioned as a delicacy, was accepted.

This, Pa' Senik was careful to explain to me the next morning, was not in this case to be considered as representing the exchange value of the rhinoceros; it was tendered and accepted only in the sense of a propitiatory offering. All that was vouchsafed was that, as far as the Earth Spirits were concerned, we were at liberty to follow the rhinoceros; whether we succeeded or not was another thing, and to that the Jin would not commit himself. But we were given an omen, and told that if we met a tiger's tracks crossing those of the rhinoceros, we were to return at once, and not to make another attempt; when we made our offering at the entrance of the forest, certain signs in the flame of a candle would tell us the disposition of the guardian spirit; and, thirdly, we were to be guided by our dreams that night. The Jin then threw Che Mat into a final frenzy and left. This ended the night's work.

We were astir early the next morning, and Malias eagerly asked me what I had dreamt. Alas! no omens were to be gathered from my dreamless sleep; nor had any one else been favoured, except my little Tamil "boy," who had been very much frightened by what he had peeped in to see overnight, and who plaintively said, in tones that showed he wished it were true, that he had dreamt of being back at my house. Pa' Senik was ready with his offering, and after breakfast he, Malias, and I set off for a walk in the forest. We had no news of the whereabouts of the rhinoceros, for, as I have said, no one would go to look for this animal's tracks; but a day would be well spent in learning as 
much as possible of the lie of the country. Pa' Senik had been directed by the Earth Spirit to make his offering at "the gateway of the forest," which is the Malay term for the place where the village foot-track leaves the open cultivated land and plunges into the virgin forest. At the "gateway," then, $\mathrm{Pa}$ ' Senik made his offering. Splitting into four the end of a bamboo, and deftly weaving the stem of a creeper through the split ends, he improvised a censer, which a couple of green leaves and a handful of earth made fire-proof. Some dry leaves and a dead twig or two made a fire, upon which he sprinkled incense. The stipulated offering was passed through the smoke, and then carefully placed on an open spot. Now came the question-what was the augury? $\mathrm{Pa}$ ' Senik lit a candle, and placed it on the edge of the censer, and, after due invocation, stepped back and keenly watched the flames. In doing this one has to stay beside the lighted candle, calling upon the spirits to attend until one feels one's skin move, then step back and watch the flame: if it flickers, it betokens the arrival of the spirits ; if, after breaking and wavering, it burns true, straight, and upright-success; extinction is failure; if it blows to the right or toward you, hope; to the left or away from you, the chances are against you. In the wind-protected corner Pa' Senik had chosen the candle burnt true and bright, and as we started hope ran high. We had a long day's walk through the forest, but to find fresh tracks was too much to expect. Old tracks, however, and abandoned wallows gave proof of "old lkramat's" existence; and the next morning I returned to my quarters well satis- 
fied at having got through the opening stages of the campaign.

Though no result was seen that day, Pa' Senik's offering had not been without its effect, for not many days later a Malay came hot-foot in search of Malias, and told him that he had that morning seen the fresh tracks of the rhinoceros crossing a native path some twelve miles away. Pa' Senik was sent for, kit and provisions packed, coolies collected and despatched, and that night we all slept in our informant's house. It stood in a small clearing, in the depths of the forest. A few hundred yards away from the door a precipitous limestone hill rose sheer out of the level plain, and towered some seven hundred feet above our heads. At sunset numbers of jungle-fowl crowed and called on every side as they came down to drink at a little stream behind the house; and a party of black gibbons made the echoes ring with their ear-piercing whoops. The wild goat lived on this limestone hill, our host Hussein informed us; one could hear them bleat at night, and they often came down from the precipitous heights to feed round his clearing, but they were very rarely seen. We went to sleep early, and the next morning I woke my men at half-past four. A tiger had roared close to the house during the night, and this made Pa' Senik rather apprehensive of the omen regarding the tiger tracks crossing the rhinoceros tracks. We made a good breakfast, and while the first jungle-cock was shrilling his clear challenge and the gibbons went whooping through the tree-tops in search of food, we started to make a wide cast through the forest to find fresh tracks of the rhinoceros. With- 
out doubt the heart of the Jin had been softened, for we had not gone more than two or three miles before we came on tracks made early the previous evening.

Pa' Senik had explained to me overnight that his "work" of the evening I have described would remain effectual for a month, and that an offering each time we entered the forest anew was all that was now required. He was provided with his censer and propitiatory gift, and in half an hour we were ready to proceed. Malias and I then went on alone, instructing $\mathrm{Pa}$ ' Senik, Hussein, and another local Malay, to follow us slowly, and to keep, so far as they could judge, a quarter of a mile behind us. We followed a well-beaten track, and it seemed from the manner in which the animal had walked steadily on, without stopping to feed on the way, that he was making for another part of the country, and that many miles lay between him and us. We were therefore taken entirely by surprise when, before we had gone more than half a mile, a turn in the path brought us suddenly upon him. He was lying at full length in a wallow; but I was unable to make use of the disadvantage at which we held him, for as I threw up my 10-bore a hanging creeper caught the barrels, and I had to lower the rifle and disengage it before I could bring it fairly to my shoulder. By this time the rhinoceros had lurched out of the pool, and I only had time for a hasty shot at his shoulder, hitting him, as I subsequently discovered, too high up and too far forward. The thick smoke of the black powder prevented me from getting a second shot before the animal disappeared in the dense forest growth. An 
examination of the tracks explained the suddenness of the encounter, for they showed that the rhinoceros had stayed the whole night long in the wallow, and the footprints proved that it really was "old kramat" that we had met. This Malias was at first inclined to doubt, for we had seen the animal plainly, and his horn was not the cubit's length of cerulean blue that every one said "old kramat" carried, but only a short, black, shapeless stump; nor had he in the least degree acted up to his reputation for pugnacity. The only fact in favour of the theory that it was he whom we had met was that there was not a sign of blood. This rather disconcerted the Malays; but I had before followed a wounded rhinoceros for three miles without finding a drop of blood (until the Malays had openly grumbled at my following an animal that had obviously been missed), and had found it when I did come up with it on the point of death-dying, I believe, from internal hemorrhage. We made but a short pause by the wallow to examine the tracks, and then pushed on. At once we were covered from head to foot, and our rifles from stock to muzzle, with the wet clay that clung to the bushes through which the rhinoceros had made its way. Slimy branches dripping with mire slapped our faces, and oozy drops of mud fell upon our heads and clotted in our hair. Then before we had worked more than a hundred yards of our way along the track a mass of white glittering clay caught my eye, and as I squatted on my heels Malias reached forward to make an excited tug at my coat. What we saw was on slightly higher ground than that on which we stood, and appeared to be at 
least seven feet high; it was perfectly motionless. An "ant-hill," whispered Malias, for it was covered with the same substance as that with which we were smeared. An ant-hill, of course, I thought, and the rhinoceros had rubbed against it in passing. And so I nodded and prepared to move forward, but as I did so the mass moved and disappeared behind the brown pile of a real ant-hill. "Allah! that was he," groaned Malias. But before I could express my feelings the animal reappeared on the other side of the covering heap, and walked slowly away from us. Though his back was well exposed, a careful aim at the base of the spine produced no effect, and (the smoke hung terribly) I had no time for a second shot; nor perhaps would I have risked it, for I felt sure that this time at all events he would charge. However, the rhinoceros went straight away, nor did we see him again for many hours. For perhaps a mile we followed him through virgin forest, where, though rattans and creepers obstructed the path, the great trees afforded a shelter from the sun. But then the rhinoceros turned aside into a clearing where two seasons before the Malays or the aboriginal Sakeis had felled the timber to grow a crop of hill-rice. The scrub that had grown up since they had reaped their harvest and abandoned the place was some ten feet high, and here the difficulty of making one's way was increased a hundredfold, and moreover we were exposed to the full force of the tropical sun. Bowing and bending to avoid the interlacing creepers, twisting and turning to free our rifles from the branches that, despite our efforts, caught their projecting muzzles, 
we had of course to move in perfect silence. The sun struck fair on our rounded backs, and we were surrounded by myriads of flies. They flew into our eyes, imprisoned themselves in our ears, or crawled clog-footed over our glistening faces. We pushed on extremely slowly, for we had no desire to come up with the rhinoceros in this horrible tangle, where we had but little chance of self-defence. There was no alternative, however, but to stick to the tracks. We could not say what line the animal intended to take, and to make a détour was therefore out of the question. The only thing to do was to give the rhinoceros time to move on, and to trust to meeting him in more favourable country. At first the track showed that he could not decide whether to go straight away or whether to refuse to leave the advantage the thick scrub gave, or, thirdly, whether to wait in the path and fight. This, of course, necessitated extreme caution, but at last after some two or three hours we emerged from the scrub and re-entered the forest. Soon afterwards we saw a few scanty drops of blood, and Malias was much reassured thereby. Then the rhinoceros took a definite line across country, and at about one o'clock we came to a small stream that it had crossed. Here we waited for Pa' Senik and the men. When they came up they informed us that we were close to the place where Japaringonen had been killed by this animal. After our meal and a cigarette we pushed on again. Before we had gone another mile a snort and rush showed that we had come up with "old kramat" again. His behaviour was most extraordinary : from a distance perhaps of some fifty yards away 
he charged headlong towards us, passing within fifteen or twenty yards of our position. The sound of saplings crashing and breaking, and creepers rending and snapping, filled the place and testified to the enormous bulk and power of the animal. When he had gone fifty yards behind us, he stopped. Here he paused a few seconds, and then with a snort charged back again at an acute angle to the last direction he had taken. He again passed close enough for us to catch a glimpse of him and to see the bushes moving, but not close enough for one to aim with any certainty. Again he stopped, paused, and then with a snort came back on another line that passed us no nearer than the others. What his intention was I cannot say; whether it was that he could not discover our exact position, or whether his wounds had knocked the inclination for real fighting out of him, I do not know; but I am inclined to believe that he did not want to fight, and think that it was what tacticians term a demonstration. He made five such rushes, but no time did he come close enough for me to take more than a snap-shot, and this, thinking that I should require my cartridges for close quarters, I refused to risk.

At last, however, Malias pointed out a stationary black object some twenty-five or thirty yards away. I could see that it was the rhinoceros, but could not make out what part of him it was. Nevertheless, thinking that I might not get a better opportunity, I fired; in another wild charge he rushed headlong through the forest straight away from us, bursting or tearing a path through every obstacle. Again we 
followed, and after another mile came up with him for the fourth time, when, after a series of similar demonstrations, he gave me a clear shot at twentyfive yards at the base of his spine. He again went straight away; but the blood showed that both this bullet and the one before had taken effect, and when we came on a place where the poor brute had lain down we made certain of him. Though we followed the tracks until four o'clock we failed, however, to come up with him again. It was now within two hours of sundown, and as we had only a rough idea of where we were, it was necessary to think of getting back. We therefore waited for the other men to come up to us, and then discussed the position: the house from which we had started that morning was many miles behind us, and it was out of the question to think of returning there. Where was the nearest house? On this question there was a divided opinion, and one of the debaters climbed a tree to prove his case, and, descending, admitted like a man that he was wrong. From the tree he could see a grove of duriantrees; and towards this spot we made our way, for we knew that from the grove a native track would lead to the nearest village. Before we left the tracks we marked a tree or two, so as to be able to start the next morning where we now left off, and then made our way toward the durian-trees. When we arrived there we found that we were within two or three miles of Pa' Senik's house, which we reached within another hour. The actual distance we had followed the rhinoceros from sunrise 
to nearly sunset was not more than fifteen miles (from point to point it was perhaps seven); but these miles had been covered step by step-carrying the weight of a heavy rifle under a tropical sun, bent double to evade the thorns that clutched at everything, stepping delicately to avoid the dead leaves that crackled under foot; and, with every nerve on the alert, we did not estimate the distance by miles.

Early the next morning we went back at the spot where we had left the tracks the evening before. We found that the rhinoceros had lain down and slept the night not far from where we had left him : he had eaten but very little, and had not wallowed. He had now, of course, many hours' start of us, and we had to make such speed as we could in order to overtake him, and yet to exercise extreme caution that we might not stumble upon him and be charged unawares. We had to move in perfect silence or we should not come up with him, and at the same time we had to keep our eyes on the tracks step by step. The difficulty of following the tracks even of a rhinoceros is extraordinary. One would imagine that an animal weighing perhaps two tons, and whose footprints are nearly twelve inches across, would be easy to follow; but time after time we had to stop, retrace our steps, or make a cast through the forest. On hard dry ground covered with leaves only the barest impression was left: we had often to lift the leaves to look for the mark of a toe-nail dinting perhaps the undermost leaf to the ground. Often, too, the tracks appeared to go straight on, and it 
might not be for some time that we found that we were on old tracks and must turn back. Traces of blood were extremely scanty, and it was only from time to time that one or the other of us would silently point to a single drop of clotted blood on a leaf or twig. The difficulty, too, and the physical exertion of moving in silence through the thick vegetation of the forest, must be undergone to be fully realised. While one hand is perhaps disengaging a thorny creeper from the shoulder, the other hand holding a heavy rifle, and one foot suspended in the air to avoid some crackling leaf, every muscle of the body is called upon to maintain the equilibrium. Moving thus in silence, we saw in the forest animals that would otherwise have been alarmed long before we came in sight. Mouse-deer repeatedly allowed us to approach within a few feet of them; twice we got among a sounder of sleeping pig before they awoke; and once an agitated tapir dashed across the track only a few yards away from me. A danger, however, there is of this silence. Malias and I had followed a wrong track for a few yards before we discovered our mistake; retracing our footsteps, we saw that beside the path lay a green puff-adder coiled and ready to strike, and that each of us had unwittingly set his foot down within six inches of its head. It was slowly thus that we made our way, and it was past one o'clock on an intensely hot day that we came up with the rhinoceros again. I then saw him some thirty yards away standing broadside on to us. His head was hidden by foliage, and it was impossible to say at which end of the 
formless mass it was. I made the inevitable mistake, and a careful aim at the spot where I imagined the heart to be only hit him far back in the quarters. As on the preceding day, he rushed away on receiving the bullet, and the country in which the tracks took us was extremely dangerous. This was another clearing made for the cultivation of hillrice such as that we had passed through the day before; but this was younger, and therefore worse. That of yesterday was some two years old, and through it one could see a few yards; this was only seven months old, and an object a foot away was invisible. Of course, I repeat, no sane man would seek an encounter with any dangerous animal in either place. But the younger growth is really wonderful: it is a mass of tangled vegetation-for here the giant lalang grass, that grows some six feet high, fights for its life with the horrible creepers that bind and choke it, and with the scrub-bushes that send their roots down into the earth to undermine it. Here, like wrestlers, they strain and pull, and the victory is to the one that can endure the longest. The loser dies, and giant grass, creepers, and scrub fight interlocked at death-grips.

Through this almost impenetrable thicket the rhinoceros made his way, and, to use a homely simile, his track looked like a double cutting on a railway line. It was necessary, therefore, to give him time to quit such desperate country, for in a patch of such wide extent a détour was out of the question. We therefore sat down for half an hour and then followed on; but soon we found that what 
appeared to be a double cutting had developed into something more like a tunnel, through which it was necessary to make our way on hands and knees. It was impossible to see more than a foot in any direction, impossible to stand, and, except with one hand on the ground, impossible to fire. I therefore again gave the order to retreat, and for another half hour we waited on the edge of the thicket. Then we heard an uproar among some monkeys on the far side of the scrub. "They are chattering at the rhinoceros," I said.

"Let us see," said Malias. And on we went again. Happily the tracks led straight on through the scrub; and as there was none of the twisting and turning we had met the day before, we were emboldened by the calls we had heard from the monkeys, and pushed on in hopes that the rhinoceros was now in more open country. Suddenly a few heat drops, generated from a steaming ground and a blazing sky, fell pattering around and on us. Malias at once seized my coat and looked on every side with perturbation. "Hujan panas," he whispered, for "hot rain" is the sign of a bloody death.

"Perhaps," I suggested, "it is a sign that the rhinoceros will die to-day."

"That is not certain," he retorted. "It may be the rhinoceros that will die, and perhaps it may not."

And then he added, very slowly and sententiously, "It is the Malay custom to be very careful when this happens."

His nerve seemed shaken for the moment, and more carefully than ever we crept along on hands 
and knees. The heat in the open scrub was terrific. The tangled vegetation we were crawling through afforded our spines and necks no protection from the sun, and the air was bound a prisoner by the giant grass and bushes that throttled one another. Waves of heat were rising from the sweltering ground in quivering lines, and more than half we breathed there was steam: this filled the throat, but, though they hammered against our ribs, could not fill the lungs. The perspiration dripped from every pore of the body, but the mouth and tongue were clogged with drought, and salt with moisture from our lips; and worse than anything else was the drumming of the nearly bursting blood-vessels behind our ears and temples. Time after time I was deceived into thinking that I heard the rhinoceros move.

At last we reached the edge of the forest in safety, and threw ourselves down in utter exhaustion. We lay there gasping until the other men came up with us, and then found that the help we had expected from them had failed us. They produced sandwiches, cigarettes, my small flask of neat whisky, but for some extraordinary reason had forgotten the bottle of cold tea. I could not touch the whisky, and without something to drink it was impossible to eat or smoke. The only thing to do was to go on. On, on, and on therefore we pushed, without finding a drop of water to alleviate our thirst and to enable us to touch the mockery of refreshment we carried. There was not a sign of the big beast that led the way, except the three round dents that marked his toes, and occasionally in softer ground the impression 
of his sole. At last, at four o'clock, as we were thinking of giving up for the day, we came on a path that Malias recognised as one leading to the village of Pinjih. We therefore waited for the other men, and after marking the place, made our way to the village. There we arrived at sunset, and a house was quickly put at our disposal. Then after a swim in the river, rice, grilled chicken, chillies, and salt fish-all that the village could offer-were ready for us.

Malias was openly despondent. Had not every one failed in this quest? And how was it that bullets that would kill an elephant dead on the spot failed even to knock this animal over? The Jin was playing with us: we were safe from his displeasure perhaps, but it did not seem that he had any intention of allowing us to kill the rhinoceros. Though Pa' Senik was more cheerful, his prognostications were even worse. The animal, he said, was making for a hill called Changkat Larang, and if it once reached that spot its wounds would immediately be healed. We had left the tracks within three miles of the hill, and our only chance was to come up with it the next day before it reached this hill of healing. Both were so down-hearted that I reminded them of the portent of the "hot rain," and suggested that the rhinoceros had returned to die by the stream and the village from which he had taken his name for so many years. But without avail. Both shook their heads in doubt, and I went to sleep, to hope for better luck the next day.

By sunrise the next morning we had finished our 
meal of rice and chicken, and set off to pick up the tracks of the day before. We were soon on the ground, and then proceeded in the same order as on the two previous days. Soon we came on the spot where "old kramat" had spent the night. He had fed heavily on lush grass and young shrubs, and had wallowed for some hours. This was bad, very bad indeed, for the night before he had barely eaten a few mouthfuls, and had not wallowed at all ; and now it seemed as though he were better and stronger after the second day than he had been after the first. $\mathrm{Pa}$ ' Senik, who was close behind, came up, shook his old head, and intimated that he had told us overnight that if the rhinoceros reached Changkat Larang his wounds would heal: the hill was now not far off, and then — I cut him short, and, picking up the tracks, pressed on. In a few minutes a rush some twenty yards ahead of us showed that our quarry was again afoot. This was worse than ever. Hitherto every time that we had come up with him we had managed to catch a glimpse of him; but now he would not let us come within sight of him, and I felt inclined to give up hope. To-day was my last chance, for I had to be back at my headquarters the next morning. The brute was stronger and better than he had been the day before, and now he refused to allow us to come to close quarters, and-climax of despair-he was heading straight for Changkat Larang.

One ray of hope remained. The rush we had heard seemed but a short one-seemed, I say; for even so huge a brute as an elephant, after its first startled 
rush, can settle down to so silent a walk that a man may be pardoned for imagining it to be standing still, whereas it is really rapidly putting a lot of ground between it and its pursuer. Praying, therefore, that the rhinoceros might really have remained stationary after the rush we had heard, I moved as rapidly and as noiselessly as possible round to the right, in the hope of cutting him off, and after a détour of a few hundred yards, had the extraordinarily good luck of finding myself close behind him. The wind was in my favour, and I was able to get within some twenty-five yards. He was looking down the path he had come up, and I had made an exact semicircle in my détour, and was diametrically behind him. I had misjudged him when I had thought a few minutes before that he would not allow me to come to close quarters, for now his every attitude meant fighting. Hustled and harried for the last two days, poor brute, he could stand it no longer, and was now determined to run no farther. Malias, crouching close on my heels, urged me in whisper to shoot at the leg, and aim to break the bone. But I hoped for a better chance than that, and squatted down to await developments. Then a slant of our wind must have reached the rhinoceros, for he very slowly began to slew round. The huge hideous head lifted high in the air and swung slowly over the shoulder, the dumpy squat horn showed black, the short hairy ears pricked forward, and a little gleam showed in the small yellow eyes; the nostrils were wrinkled high, and the upper lip curled right back over the gums, as he sought to seek the source of the tainted air. 
Pain and wrath were pictured in every ungainly action and hideous feature. High in the air he held his head as he turned round, high above us as we squatted close to the ground; and his neck was fairly exposed to a shot, but I waited to let him show yet more. Then-how slowly it was I cannot say, but very slowly it seemed-his shoulder swung round, and at last I was afforded a quartering shot at the heart and lungs. I fired, and knew that he was mine. A short rush of some thirty yards, and he fell in an open grassy glade, never to rise, and never again to see Changkat Larang.

Though he could not rise, the poor brute was not dead; and as he moved his head lizard-like from side to side in his efforts to raise his ponderous body, he seemed more like a prehistoric animal than one of our times. The head of a lizard it was exactly, and the body of an elephant was joined on to it. Another shot killed it. When the other men came up, the two local Malays were wildly excited. Malias was nearly off his head. He examined the feet whose tracks we had followed so long and so far, the skin, the head, the teeth that killed Japaringonen and the two other men who had died so long ago that their names had been forgotten, the horn that was said to carry the famous blue which cured Kanda Daud. He touched and handled every part of the animal, and returned to touch and handle it with fresh interest-in fact, he behaved exactly like a terrier puppy with its first rabbit. But old Pa' Senik, when he had uttered a short charm over the body to preserve us all from the consequences of its death, stood back a little space 
and looked on with folded arms. It was not in the company of such mere mortals as Malias and myself that he had been hunting : for the last three days he had been in the mighty presence of the Earth Spirit, who step for step had been with us in the forest. In $\mathrm{Pa}$ ' Senik's eyes the day's success was the result of the promise made when Che Mat had been possessed, and only a line at the corner of his mouth and a gleam in his old eyes showed the grim satisfaction with which he viewed the victim of the compact.

After a short rest I sent $\mathrm{Pa}^{\prime}$ Senik and the two Malays to the house where we had slept three nights before to fetch my servants, my clothes, and my camera, and ordered Malias to follow me to Pinjih village to get some pack-elephants to carry the rhinoceros' head and feet.

It was with the greatest difficulty that I induced Malias to leave the body.

"Some one must stay and look after it," he said.

"But it's dead now," I objected.

"Yes," he said with firm conviction; "but it was dead after Kanda Daud shot it, and it came to life again and nearly killed him."

And he then asked to be allowed to stay behind, to shoot it again if it showed any symptoms of returning vitality.

It was with some trouble that he was finally persuaded to come away; but not even then would he move until he had hacked one of the hind-feet nearly off.

"If he does go, he will go lame," he said.

We found Pinjih village seething with excitement. 
My shots had been heard, and the entire population was waiting for news of an event that meant more to the villagers than it is easy to realise.

By noon I had collected three elephants, and on the arrival of the men with my camera and impedimenta we returned to take some snap-shots (which were not a success), and to cut off the head and feet of the rhinoceros.

Between two upright posts at the shoulder and fore-feet I made out its height to be 5 feet $5 \frac{1}{2}$ inches. I am certain, however, that the measurement did not do it justice: it had fallen in a cramped position, and it was impossible to stretch it out. Measurement between uprights is the best way of taking records of dead game, but it is a poor way: one can imagine the difference between measuring a horse standing up and a horse lying down. When I caught my second glimpse of the animal, it appeared to be nearly seven feet high. I am sure that it was but little short of six feet high.

The horn was disappointingly small, the more so because it had been said to be so extraordinarily fine. It was a short shapeless lump, only some seven or eight inches high; but I think that it had once been much longer. The tip had been broken off, and the base was much worn and splintered.

Through the crowd that collected round us as we cut off the feet, a lame old man pushed his way up to the headman, who brought him up to me and explained that this was one of the rhinoceros' victims. He was Kanda Daud, to whom I have already referred, and the story of his adventure was briefly as follows: 
Years before, "in the days when the white man had not yet come into the country," and when he was a young man, he had felled a patch of forest in the Pinjih valley to make a plantation of hill padi. The crop was nearing the harvest, and he was sitting at night with his gun to keep away the pigs and deer, when this rhinoceros came out of the forest and fed close up to his house. He fired, and heard the brute rush away and fall at the forest's edge. The next morning he went with a youngster to hack off its horn, when the animal threw off the semblance of death and charged him. He fell, and the rhinoceros did not gore him with his horn, as is the custom of the African animal, but bit him with its enormous razor-edged teeth. The boy ran away, and in a few minutes returned with some ten men, whose approach frightened the brute. Kanda Daud appeared to be dead when they picked him up and took him to his house. Though the wretched man had been bitten in almost every part of his body, he recovered, and as he limped beside me to see the dead body of his old enemy, he showed me the cicatrices of his wounds. The calf and the fleshy part of the thigh of the left leg had atrophied; they had been bitten away; and the ball of his toe reached the ground in a painful hobble. On his ribs and under one arm were great drawn lines of hideous white, such as one associates with the idea of a scald. The muscles of an arm had disappeared, and there only remained a bone. It was marvellous that he had recovered; but when I told him so he replied that when he was picked up and taken home, his hands and arms were found to 
be stained with an indigo blue. This was the dye of the rhinoceros' horn, which he had seized with both hands in his efforts to free himself from the brute as it held him on the ground. His hands and arms had been carefully washed, and the stained water was the only medicine that he was given. Part he drank, and with part his wounds were washed. It was indeed a marvellous recovery. And the poor old man talked excitedly, as he limped along, of the result he expected from getting more of this remedy: perhaps with a further supply a skilled pawang might make the flesh grow on his withered limbs. Didn't we think so? A very little had served to heal his wounds, surely an unlimited supply would bring a perfect cure. For more than twenty-perhaps thirty-years the old man had been waiting for this event, and at last the day had come. Bitter was his disappointment, and pitiable to see, when he reached the carcass, for no amount of rubbing and washing would yield a sign of the desired blue from that black stumpy horn. The Malays stood back and whispered in little groups. All felt sorry for him, but it was difficult to know what to do. Finally I touched him on the shoulder.

"The rhinoceros is very old, Kanda Daud," I said, "and now in his old age the blue stain he carried has disappeared."

He stood up and looked at me in silence for a moment. "And I am very old too," he said; and then he added as he turned away, "and now I shall never recover." 


\section{A DEER-DRIVE.}

IN the corner of many Malay houses one may often see a curious bundle of rattan. It is coiled into great loops in the manner that a sailor coils a rope, and the inquirer is told that it is a sidin. If he inquires further, he will be told that it is used in deer-drives; and if he is still curious, it may be exhibited for his inspection. The great ring of rattan opens out into a straight line some twenty-five or thirty yards long. The main line is of plaited and twisted rattans, and is about an inch thick, and from this line hangs a series of nooses. Each noose is made of three fine rattans plaited together, and forms, when spread, a circle about three and a half feet in diameter. They hang from the main line at intervals of eighteen inches, and therefore overlap considerably; the catch is the ordinary running knot. In a deer-drive the sidins are stretched in a long line in some favourably situated part of the forest, and the deer are driven in that direction. The number of sidins used depends, of course, upon the locality. Ten are generally enough, for they form, when tied end to end, a line nearly 300 yards long, with 600 nooses; but sometimes twenty, or even thirty, are used. 
The Malays use sidins, rather than more sporting methods, in a deer-drive for many reasons. The forest is often a featureless wilderness of trees and undergrowth, in which an unbroken line of nooses some hundreds of yards long has a better chance of stopping a deer than a few men armed with guns; and two or three guns is generally all that a village can produce. Then the undergrowth beneath the trees is almost always so dense that a deer may pass unseen between two men not more than fifty yards apart, and under the most favourable circumstances it is rare to get more than a snap-shot. The Malay is an execrable shot, and seldom succeeds in shooting a running deer. It takes him half a minute or more to squint along the barrels of a gun before he will fire at an animal the size of a bullock standing at rest twenty yards away, and if he stops the headlong rush of a driven deer he is generally as much surprised as the rest of the company at his success.

A deer-drive with sidins is perhaps the favourite form of sport among the Malays; and if deer are known to be in any patch of forest that can be beaten out, a suggestion to have a hunt is generally welcomed. Rusa (the sambar deer of India) are fairly common everywhere throughout the peninsula, and often do considerable damage by their depredations in the rice-fields when the crops are ripening.

Let me describe an imaginary deer-drive. For the past two or three nights a couple of deer have been feeding in the rice-fields, and lying up by day in an adjoining patch of secondary forest. The injured cultivators go to the village headman, who at their 
suggestion decides to have a deer-drive on the following day. Messages are sent from mouth to mouth on all sides, and before many hours elapse every one. knows that he is expected to be at the headman's house the next morning at daybreak, and to bring his sidin, if he chances to have one, with him.

While still a star or two shines whitely through the grey morning light, and while the night-jars are still wheeling and calling tĕ-tě-gôh, tě-tě-gôh, the Malays leave their homes and begin to gather round the headman's hoúse.

Those that own sidins bring them slung on their shoulders, and every man is armed. The majority have spears, others carry a dagger or kris in their belt, and the remainder have the long-bladed knife called a parang. This last is the everyday companion of the Malay, and he carries one from the day that he can toddle, gradually emerging from the state of cutting himself with it to that of cutting everything else. With a sharpened edge nearly two feet long, it is equally useful for cutting down a small tree or for putting an edge to a copper fish-hook or extracting a thorn. It will slice a man nearly in two, and more than one tiger has been brought in for the Government reward by a Malay who had nothing else with which to defend himself.

The gathering increases momentarily, and there is a violent barking and yapping of the headman's housedogs as some strange dogs are brought forward and tied up to separate trees. Unhappy-looking brutes are these last - small yellow animals, with sharp noses and prick ears: they are, I believe, direct descendants of the wild dog. They are generally 
much better than they look, and the most insignificant in appearance has perhaps a reputation that extends throughout the district. While some men are overhauling the sidins for flaws, a small circle surrounds a man who is loading his muzzle-loader. The powder is the vilest German rubbish, or, failing that, stuff that he has collected out of Chinese bombs, and what is lacking in quality is made up in quantity. His wadding is a piece of cocoanut husk, and the missiles are a lump of hammered tin and a piece of iron of the length and thickness of a little finger that he has hacked off some worn-out agricultural instrument. The only other men with guns are an old haji, ${ }^{1}$ who has a snider, and the headman's son, who carries a double-barrelled shot-gun.

The old man squatting at the foot of a cocoanuttree and tracing figures in the sand with his finger is the pawang, on whose skill the success of the drive will depend. In addition to a belief that certain animals are protected by attendant spirits, the Malays believe that the death of any animal is avenged by influences known as bahdi, jinggi, and genaling. The bahdi have, they believe, the power of bringing sickness, blindness, or madness upon the hunter, and an attack of fever after unwonted exertion in a malarial forest is always ascribed to them. The jinggi can let the deer pass by the unwitting hunter in the form of a mouse or attack him in the form of a tiger. They can also give the hunter the appearance of the hunted, and thus expose him to the fire of his friends. The genaling can kill the hunter outright; but being

1 One who has performed the pilgrimage to Mecca. 
the strongest, are perhaps the most merciful, for I have never heard of a death being laid to their door. With such dangerous enemies to combat, the old pawang has no light task, for on him falls all the responsibility for any accident or mischance, unless he can shift the blame on to the injured party. This, however, let it be said to his credit, he can generally do satisfactorily.

The old man is working out with lines and crosses a calculation, based principally upon the day of the month, which will show from which direction danger may be expected. Beside him lies a sidin, known as "the head of the sidins." It is supposed to have a peculiar efficacy, and may be distinguished from the others by its being ornamented with the skull of some such bird as a kingfisher or a woodpecker, and with a bit of some curiously twisted root or creeper.

By the time that the sun is above the horizon two men, who had been told off overnight to examine the rice-fields for fresh deer tracks, return and report that the deer have fed again in the crops, and that, as on the preceding days, they have entered the patch of secondary forest, where they almost certainly now are. The headman comes down from his house, and there is a general discussion as to the direction of the intended drive. The arguments show that the ground in which the deer are supposed to be is of considerable extent, and that it is bounded on one side by the rice-fields and on the opposite side by a deep swamp. On the south it runs into a narrow neck, which connects it with a limitless expanse of 
virgin forest. The ground can be driven in two ways, either directly away from the rice-fields and towards a row of sidins erected alongside the swamp, or the line of the drive may be parallel to the rice-fields, in which case the sidins would be set up at the "neck."

The pawang takes everything into consideration,his experience of former drives in the same place, the direction of the wind, and his own forecast regarding the side from which danger may come,--and decides to have the line of sidins at the neck.

The word to start is given, each man shoulders his heavy coil of nooses, the headman leads the way, and in irregular single file the party follows him. The village through which their path leads at first is not what we mean by a village in English. Our interpretation of the word is a collection of houses. The Malay village is a collection of holdings. Each man owns his two or three acres of land, in the middle of which his house stands; and as the holdings generally extend in a narrow strip along a river bank, a village containing only a hundred houses is perhaps two miles long. Each man's holding is more or less thickly planted with coco-nut-trees and with a somewhat miscellaneous assortment of fruittrees, round the roots of which grows a neglected crop of grass where goats and an occasional sheep find pasturage. The only public buildings in the village are the musjid, which is the property of the community, and the school, which is the property of the Government. The nearest police-station is thirty miles away. 
When the path leaves the village it emerges upon the level and scientifically irrigated rice-fields, and continues, a foot or so above the level of the liquid mud, along one of the innumerable little embankments that criss-cross in every direction, and serve the double purpose of retaining the vivifying water and of forming boundaries between one man's crop and another.

There are no houses in the rice-fields, but here and there are rude shelters consisting of a few bamboos and palm leaves strung together, which afford a certain amount of protection to workers during the heat of the day, and which are useful when it is necessary to protect the ripe crops from the depredations of wild pig and occasional deer.

The two men who had found the fresh deer tracks earlier in the morning point out silently and from afar where the deer had entered the rice-fields, where they had fed, and where they had re-entered the forest. The path now skirts along the edge of the forest, and as the deer may be lying up within a stone's throw of the party, no one talks above a whisper. The men soon arrive at the neck between the secondary forest and the virgin forest, and here the strictest silence is enjoined. The pawang points out the line in which he wishes the sidins to be erected, and as quietly as possible some men clear a track a foot wide along this line. They have to take care that, while cutting away as many branches, creepers, and rattans as will allow the sidins to hang freely, they do not cut away so much as to make the nooses conspicuous. This is soon done, and all stand aside. 
The pawang picks up "the head of the sidins," slings it over his right shoulder, and looks round for a suitable tree to which to tie it. Selecting one on the line that has just been cut, he chips off a small piece of the bark with his knife. The bark falls to the ground on its face-that is, with the inner side downwards-and the tree is a lucky one. (Were the bark to fall on its back another tree would be chipped until a lucky one is found.) Taking care, then, not to stand on the roots of the tree or in its shadow, he grasps it with his left hand at about the height of his head, and in a rapid mutter, with here and there a word thrown in in a louder tone, he makes this petition. The words cannot be distinguished by the listener, but the following is a literal translation:-

"Hail ! all hail !

Mother to the earth!

Father to the sky!

Brother to the water!

I crave permission to enter on your domain, And to tie my nooses to this tree."

This preliminary invocation is over in a few seconds. The pawang then opens the strings that bind the still coiled-up nooses, takes hold of the rope at the end of the main line of the sidin, and brings this rope round the tree at about five feet from the ground, so that it will be ready to be tied when he has finished the next invocation. Then in the same guttural tones he begins the charm against untoward influences. It is of four lines and in rude verse, being 
the only one of this collection that is so. As is always the case in Malay verses, the first two lines mean little, and are only there to rhyme with the last two. In such manner does the artless Malay evade a difficulty that poets of more civilised countries struggle to surmount.

\section{"Sîrłh ûntă pînăng untă Mârî tănăm tĕpî blûkăr Hăntâ bată mâlăng bată Jěrăt âkû kătăkăn âkăr."}

The lines may be thus translated:-

Betel leaf, Camel, Betel nut, Camel.

Come, let us plant at the edge of the young forest.

Evil spirit be blind ! Evil influence be blind !

Say that my nooses are but forest creepers !

The pawang then ties the rope round the tree, and leaves the indefinite to address the jinggi, bahdi, and genaling, who are more particularly interested in the work that is toward.

"O evil spirits !

Down with your powers, may my power defeat them !

Down with your charms, may my charms defeat them !

One hundred and ninety charms!

Move ye from hence!

Go to birdless forests,

To fishless seas,

To rockless mountains,

To grassless plains !

Go in the name of Allah."

The pawang now opens the first three nooses of the 
sidin, and moves back a pace or two from the tree. $\mathrm{He}$ calls on the deer-

\section{"Hail ! all hail !}

Ye that trample the earth !

Ye that pass like lightning-flash !

If ye pass the nooses' farthest end,

$\mathrm{Ye}$ fall into the deepest seas ;

And if ye pass the nearer end

Ye reach the great volcano's fire.

Take ye the broad road by the high land!

Here is the way for ye to follow

To return to the fold of Nabi Sleman."

This last line is illustrative of the Malays' belief in an animal's sanctuary, the fold of their master $\mathrm{Nabi}$ Sleman (King Solomon, who is one of the prophets of the Muhammadan religion). Within this sanctuary only animals that have obeyed the laws of their kind are admitted. It is imagined that the deer which live close to the habitations of human beings, and which feed on the crops of man, are trespassers, and have done wrong by wandering too far from their proper home. By so doing wrong they have forfeited in part, but only in part, the protection of forest spirits. It follows, therefore, that the deer which frequent the haunts of men are an easier quarry than the purely forest-dwelling deer; and it is the former, for obvious reasons connected with the accessibility and nature of the ground, that are more often caught. A further development of this idea of wrong-doing is seen in the case of man-eating tigers and crocodiles, which are imagined, by their unnatural appetites, to have put themselves outside the pale of God's creatures, 
and to be surrendered by the spirits to traps and snares that animals which have not so transgressed would detect.

But to return to our deer. They are warned of the perils of fire and flood that lie to right and left of the only way back to the fold of Nabi Sleman. Across this way lies the long line of nooses, and they are to return-if they can.

When this invocation to the deer is concluded, the strength of the knot and rope is tested by a strong pull, and lastly the sidins are addressed-

\section{"Hail! all hail !}

Thou long and trembling line!

If two deer pass, hold thou two ;

If only one pass, hold thou him;

Be he big or small, hold him!

And I will speak good, not ill, of thee.

If thou breakest, I will not mend thee ;

If thou art lost, I will not seek thee."

Ptu-ptu-ptu. The pawang spits three times on the knot, and rapidly unrolls the rest of the sidin. Every one gives a long breath, for the ceremony, which has lasted two or three minutes, is over. The extremity of the sidin is tied to a convenient tree on the line that has been cut through the forest, and another bundle of nooses is brought up to the pawang, who unrolls it and ties one end of it to the tree where the first sidin stops, and continues his way along the line. Where the second ends the third begins, and in a few minutes the sidins are transformed from a number of circular bundles of rattans into a continuous line of nooses some 
hundreds of yards long, and stretching right across the narrow "neck" that lies between the ground to be driven and the virgin forest. The series of sidins which form this line of nooses are independent of one another, for each is supported by the trees to which it is tied at either extremity, and in no way by the adjacent sidins. Thus, if any one is torn down by a deer, the displacement does not affect the others. To prevent any sagging, the long line of nooses is propped up between the supporting trees by forked saplings. The main line is about five feet from the ground, and the bottom of the nooses is at the height of one's knee, or about eighteen inches above the ground. While tying to a tree the end of the last sidin, the pawang makes the following petition:-

"O Têjah-tree at the head of my sidin!

O Casuarina-tree at its foot !

Remain ye here, I go to hunt

The deer, the raiats ${ }^{1}$ of Nabi Sleman."

The preparations for the drive are now complete, and the men are divided into three groups-one to drive, another lot to "stop" along the edge of the swamp to turn the deer in the unlikely event of its attempting to break away in that direction, and the third lot to watch the sidins. There is little doubt as to which is most favoured work.

1 The derivation of this word shows how apt its use is in this connection. Yule and Burnell's 'Glossary of Anglo-Indian Words' has the following: "Ryot. Arabic ra'iyat (from ra' $a$, to pasture), meaning orginally, according to its etymology, 'a herd at pasture,' but then 'subjects' collectively. It is by natives used for a 'subject' in India." 
The drivers have to make a détour of some two or three miles to reach the point from which the drive will begin, and then to form into line and advance upon the line of nooses where the whole party now stands, and where, of course, the drive will end. This to the indolent Malay is no light work; moreover, the drivers see but little of the game. The stops have not so far to go, but they also have small share of the fun; while those who are detailed off to watch the sidins not only remain where they are, but have all the excitement of seeing the deer crash headlong into the noose and of hamstringing the entangled animal. The manœuvres to secure these last most favoured spots are amusing, but the headman is stern and will stand no nonsense. He relaxes his strictness in favour of an old man who successfully pleads a combination of headache, a cut finger, dizziness, and stomach-ache, and who is accordingly allowed to stop and watch the sidins. But two or three skulkers who are found hiding behind trees are ignominiously ordered off to join the drivers. At last diplomacy and argument are exhausted, and the arrangements are complete. The drivers and stops move off, and the watchers take up their station at intervals along the sidin, and about thirty yards away from it on the side from which the deer are expected. They put a few leafy boughs together to screen themselves from view, and, settling themselves in the smallest possible space, crouch concealed and motionless.

The men told off to drive reach their places at last, and as soon as the line has been formed they advance 
upon the sidins with shouts and yells. When the pawang hits upon the fresh deer tracks, he lets loose the dogs that have hitherto been in leash, muttering as he slips them-

"Go, my dogs ! Si Panji Lela! Si Panji Ladang !

Go hunt ye the raiats of Nabi Sleman,

Who trample the earth, who pass like lightning-flash,

Wearing earrings of gold and waistlets of gold,

Who wait outside the fold of Nabi Sleman."

When the dogs give tongue, the owner shouts a long tu-u-u-u to encourage them, adding under his breath the mystic words-

\section{Telekul lam telekul,}

This is in the hands of Raja Una.

(Raja Una is the Nimrod of Malay mythology.) Soon the dogs are in full cry, and after a few minutes of tremendous excitement, during which the deer attempts to break out, but is judiciously turned by one of the stops, the hunted animal, with the dogs close upon its heels, dashes into one of the nooses. The sidin for some yards at either side is torn from the slender saplings that support it, and gives to the impetus until the strain is felt at the two extremities where it is tied to the trees. It then suddenly tautens and throws the deer down. The nearest of the ambushed watchers runs out, hamstrings the deer, and, if he happens to be a haji, cuts its throat, repeating as he does so a verse of the Koran; but if not, with that callous indifference to pain in animals so marked in all Asiatics, he allows the animal to live until a haji comes up. But in the meanwhile he 
hastily and roughly replaces the sidin, which has been disarranged in the struggle, calls off the dogs, and quickly goes back to his hiding-place, in the hope that there may be another deer in the ground. The stricken animal is not released from the fatal noose that holds it; but it rarely struggles after being hamstrung, apparently giving itself up to death.

While this is going on at the sidin, a shot is heard from the beaters' side, and before long they come up, and the drive is over. Questions and answers are shouted on every side. The success that has attended the nooses is equalled by that of Che Mamud, the headman's son, who was with the beaters, and who has shot a deer that was concealing itself in a thicket in the hope of breaking back through the line. It is lucky that he succeeded in so doing, for his neighbour would probably otherwise have got the bullet, the jinggi the blame, and the poor pawang the reproaches. Nothing, however, goes wrong to-day, and the second deer is brought up by four men and deposited close by the still living animal. The throat of the latter is then cut with all ceremony. The throat of the other deer was cut as soon as it was shot, for fear of its dying of the wound, in which case it would not have been lawful food for Muhammadans. It is interesting, as showing the distinction between the Malays' present religion and their pre-Muhammadan superstition, that this ceremony is not performed by the pawang.

There is now an interval for rest and refreshment, and while the cigarettes and betel-leaf pass round, the incidents of the day and the weight of the deer 
are discussed. The man who turned the first deer and the man who hamstrung it tell their story with many details and some improvements, and Che Mamud shows them all how he saw and aimed at and shot his deer. Every one congratulates the pawang, to whom the credit of the success is considered to be entirely due; and the enthusiastic or ingenious compare the present success, with obvious deductions, to the failure that attended the efforts of his rival in the neighbouring village on the occasion of the last deer-drive undertaken there. The congratulations generally take the characteristic Malay form of an address to the speaker's nearest neighbour, in a tone of voice that is most obviously meant for the general ear, and especially for the ear of the subject of the eulogy. It is a somewhat artificial method, but none the less sweet; and really to-day the pawang is to be congratulated, for mishaps are far from rare. Often the deer breaks back or escapes at the side. Sometimes the noose is old and rotten, and snaps; and even when caught, a hind will, if not quickly hamstrung, extricate itself by getting its forefeet into and loosening the catch round its neck. A stag can rarely get free because of its antlers.

But to-day everything has gone well, and when all are sufficiently rested the pawang rises to complete the ceremonies. He first goes up to Che Mamud and takes his gun from him; then, going to the deer which Che Mamud had shot, he stands between its fore-legs and hind-legs. Holding the gun with his left hand. near the lock and his right hand some way up the stock, he points the muzzle at the head of the 
animal. He then slowly passes the muzzle of the gun over the deer from the head over the neck, along the back, and down to the extremity of the hind-legs. When he gets to the end he carries the gun smartly off from the body, with the action of one sweeping something away. Going through this performance three times, he repeats the following words-

\section{"O bahdi!}

I know whence ye got your powers.

With the fall of Adam your powers began.

I have the means to destroy your powers.

\section{O Malik Zabaniah!}

Keeper of the gate of the end of the world, Open a secret door for me ;

I wish to throw away all the powers of bahdi.

Open a place from which there is no return;

I wish to throw away all the powers of genaling.

Let no claim be made against me, Against my house and family, Against my friends and companions, Or against my hounds. If claim is made, Thou shalt be doomed to Hell by Allah."

He then, in the low muttering tone he has used throughout, counts one - two - three - up to ten, and then shouts "Lepas!"- "Be free!" Every one echoes the cry, and the deer is now freed from evil influences.

This performance is called sapu bahdi, or sweeping away the evil influences, which are supposed to follow the direction of the gun, and be thus expelled from the body of the deer. Until this is done every one takes great care to avoid standing behind the deer, 
for soon after death the bristles on the back move, and stand on end with the contraction or relaxation of the muscles; and to come within the range of the aim of these bristles, which have the position they assume when the living animal is enraged, is to invite the attacks of the bahdi. It is thought that they are waiting to avenge the death of the deer, and that the movement of the bristles is caused by their preparation to leave the body of their protégé : until driven out by the pawang, they will dart out upon any one who passes, and inflict upon him such ill as is in their power. No one, of course, is absolutely safe from them, for they can move freely anywhere, but a position at which the bristles point is one of supreme danger. The pawang then hands the gun back to the owner, proceeds to cut a leafy branch from some tree close by, and lops a second branch, of which he makes a small stake. He goes up to the deer, which still lies with the noose round its neck, and drives the stake into the ground close to its heels. Then standing in the same position to the deer as in the last case, he passes the branch three times over its body in the same way that he had done with the gun before, and using the same words. The ceremony is not, however, complete when he has done this, for he next works the noose from the neck of the deer down over the body and along to the heels of the hind-legs. Here he draws the noose tight again, and then suddenly slips it from the heels on to the stake placed in readiness, upon which he tightens it, and shouts "Lepas!"

The shout is again echoed, and the ceremony com- 
plete. The idea is the same as that already mentioned, and the evil influences are imagined to be transferred with the noose to the stake, and there to be localised. The two deer are then cut up, the pawang taking a quarter of each animal, and the rest of the meat being divided among the men: the antlers go to the village head-man. Cigarettes and betel-leaf are again produced. After a short rest the fatal noose is slipped from the stake, which is not again touched, the sidins are rolled up, and the men return to the village contented. 


\section{CROCODILE CATCHING.}

WE were in the back verandah of my bungalow, and in front of me a Malay squatted on the floor, and beside him were weird implements-some gigantic hooks, four or five coils of rattan, a basket full of odds and ends, and four dead fowls.

Manap was his name,-Abdulmanap bin Muhammad Arsad, to give him his full ceremonial name, and Manap Rimau or Tiger Manap, to give him his distinguishing name. He was a professional crocodile catcher, making his living out of the reward offered by the Government for the extermination of these animals. His skill and extraordinary daring in shooting tigers, also of course for the Government reward, had earned him his sobriquet. He lived near the sea, close to the mangrove swamps where his work lay, and had come up to Taiping in answer to a letter from me. As he sat on the floor amid his paraphernalia we talked of indifferent subjects for the period prescribed by etiquette, and then I asked him to show me the lines he had brought with him.

"It is cooler in the house than by the lake," he said, picking up the basket; "shall I bait the hooks here?" $\mathrm{He}$ pulled out a knife, with a cutting edge some 
twenty inches long, and carefully thumbed the blade. "And the Tuan wants to know not only how to catch crocodiles but learn the charms and lore in connection with it? Well, whatever it be that one intends to learn, one must start from the beginning. The boys at school begin with Alif, the first letter of the alphabet, and to catch crocodiles one must know the beginning of crocodiles. The first crocodile had its origin in the following manner. Siti Fatimah was the daughter of the Prophet Muhammad, and Petri Padang Gerinsing was the name of her nurse. One day the nurse took the sheath of a betel-nut palmleaf, and on it moulded some clay into the shape of what is now a crocodile; and the palm-leaf sheath formed the belly of the animal. Of the joints of some sugar-cane she made its ribs. On its head she placed a pointed stone, and bits of turmeric formed its eyes; its tail was a leaf of the betel-nut palm. She then tried to give life to it, but at once it fell to pieces. Twice this happened, but the third time she prayed to the Almighty God for life for it, and at once the animal breathed and moved. For many years it was the plaything of the prophet's daughter, but at last, with increasing size, it became disobedient, and, Petri Padang Gerinsing being by this time old and feeble, Siti Fatimah cursed the animal, saying, "Thou shalt become the crocodile of the sea, nothing that thou shalt eat shall have taste for thee, and pleasure and desire shall not be known to thee.' She forthwith drew out all its teeth and pulled the tonsils from its mouth, and then to close its mouth drove nails through from the upper to the lower jaw and from the lower 
to the upper jaw. The crocodile was allowed to escape, but soon found a way to open its jaws, and the nails driven in by Siti Fatimah have become the teeth that it now has."

Manap knew the folk-story off by heart, and probably repeated it in the identical words, in which he had first heard it.

"Now," he continued, "we must remember this: the eyes of the first crocodile were made of turmeric, and to this day a crocodile cannot struggle successfully against a man who knows the properties of turmeric. A piece of it rubbed on the line weakens the crocodile's resistance, and if we sprinkle the boat with water in which it has been soaked the crocodile will not attack it. Turmeric, if rubbed on a crocodile's head, when the proper charms are repeated, will quickly kill it."

"And this is the way to bait the hooks."

From the coil of rattans he produced one about twenty yards long; a piece of stout native-made rope about three yards long was attached to one end of it, and at the end of the rope was a hook. The fine strands of which the rope was composed were separate from one another, and when the hook was taken by a crocodile they would slip into the interstices of its teeth and afford nothing on to which the animal could bite.

The hook was some seven inches long, and three and a half inches across from point to shank. It was of native-wrought iron, and half-way up the shank on the side towards the point of the hook was a loop. The rope was attached to the hook at this loop; that is to say, it was attached to the hook half-way up the 
shank, instead of at the end of the shank, as is the case in the ordinary hook. The point of the hook was not barbed, and the end of the shank was sharpened.

The effect of this curious attachment is obvious: supposing the bait to be swallowed, a strain on the line would tend to pull the hook transversely across the gullet of the crocodile; the point of the hook would catch in some part of the throat, and, as soon as this happened, the sharpened shank-point would catch in the opposite side of the throat. An animal thus hooked could only escape by breaking the line.

"I brought fowls for bait because I was hurried. White fowls are the best, for the crocodile can see them farther, but if I had had time I would have shot a monkey. There is nothing that a crocodile likes better than one of the grey long-tailed kind. He sees them playing and leaping in the mangrove-trees at high tide, and trooping over the mud flats at low tide : at all times they scream and scold and chatter at him, for between the crocodile and the monkey there is an old standing feud. It is seldom that a crocodile catches a monkey, but when he does it is very sweet to him."

Manap then took a fowl, which he had previously gutted and half-plucked, and eyed it carefully, and, after looking at it and at the hook from every point of view, split it open down the breast. He then buried the length of the hook in the incision he had made. The bend of the hook fitted closely to the curve of the fowl's rump, and the hook's point was hidden under the wing, while the sharpened point of the shank could be felt near the fowl's neck. With some native fibre he then bound the bait as tightly as 
possible to the hook near the loop, taking great care not to impede the pivotal action of the loop. At the two extremities of the hook he tied the bait on with a much finer fibre, and tied it so that, while the meat could not slip and uncover the hook, yet at a sudden jerk on the main line the slender bands would snap, and the hook-point and shank-point would start from the protecting covering and stand ready to pierce any part of the crocodile's gullet that they might touch.

It did not take him long to bait the four hooks he had brought, and he was then ready to make a start. In the meantime I had explained the reason of my having sent for him. Taiping, the town in which we were, is the capital of the leading native state of the Malay Peninsula, and is happy in the possession of a beautiful public garden and an ornamental lake. Until they were made, their site had been a wilderness of abandoned mine-holesand spoil-banks. The Chinese method of winning alluvial tin ore (the mineral on which the source of the wealth of Perak at present depends) is to open an enormous pit and to bodily remove the earth from it until the substratum that carries the tin ore is exposed. When the mine is worked out and abandoned, there is left a hole which may vary from twenty to sixty feet in depth, and which, in exceptional cases, may extend for half a mile in length and a hundred yards or more in breadth; and beside this gigantic excavation, which in the rainy climate of the Peninsula quickly fills to the brim with water, there are mounds of corresponding extent where the overburden has been taken out and deposited. To form the Taiping lake a series of such abandoned mines 
were connected, a dam erected at their lower end, and a small mountain-stream deviated into the enclosure. Many of the old spoil-banks were left to form islands in the lake, some of them covered with closely-mown turf and dotted with palms, while others, by way of contrast, were allowed to remain under the wild, rank, luxuriant growth of nature. A circular road, some two miles long, runs through the gardens and round the lake, and here the European community rides and drives in the afternoon; the golf-links are on one side, and on the other is the race-course. It is not the sort of place where one would expect to find crocodiles: one looks for them in tidal rivers or backwaters, but not in an artificial lake in a public garden. Crocodiles have, however, the most extraordinary roving propensities, and often leave their native river to make journeys of many miles overland. In the interior of Perak they have been found in abandoned mine-holes so far from any stream that it is difficult even to guess from which direction they have wandered, or to tell whether it was by an accident or design that they have discovered an isolated pool in a limitless extent of tropical forest. It made it none the less extraordinary, but it was easy to see how the crocodiles had got into the Taiping lake: the Squirrel River, though a small, shallow, gravelly stream, incapable of affording food or shelter to a crocodile, runs close by, and lower down joins a tidal river. A crocodile could make its way either up the channel of the Squirrel or through the forest on its bank for a distance of some three miles, and it would then be opposite the lake. After that, to travel some two or three hundred yards 
overland and to cross a metalled cart-road would afford but little difficulty. It is easy to see how it is done, but who can say why it is done? Why should a crocodile leave a river stocked with food, and explore an utterly unsuitable tributary for miles and then wander inland until it strikes a pool? All that one can say is, that it does; and rumour had it that three of these brutes had found their way into the lake. So long as they confined their attention to the fish, and perhaps an occasional duck, no one objected to their presence; but when one of them began to take the sheep off the bank as they came down to drink, and had even gone so far as to make an attempt on a cow, it was felt that the brutes ought to be exterminated. When children and ayahs were playing at the water's edge anything might happen. The crocodiles never came up to sleep on the bank in the heat of the day, for they had not yet so far made themselves at home as to dare to expose themselves to the public gaze. There was therefore no chance of shooting them, and so I sent for Manap.

When the baits were all ready Manap and I went down to the lake and pushed off in a Malay dug-out to reconnoitre. The lake was fairly shallow toward the sides, but in the centre there were some very deep old mine-holes, and to approach these pools, which were almost certainly where the crocodiles were to be found, one had to pass by one or another of the islands. We decided to leave a baited line at each entrance between the islands, and Manap proceeded to unwind one of the coils of rattan, and straitened out the curves in it until it followed the canoe, floating on the top of the 
water like a yellow snake. Out of his basket he produced a piece of wood large enough to carry the hook and bait, and buoyant enough to support its weight above the level of the water. To this wood he fastened the bait with some bamboo pegs, and then gently stopped the canoe at a narrow entrance that led between two islands to a deep secluded pool. Carefully placing the bait and its wooden support in the water, so that it floated true and upright, he muttered the following invocation:-

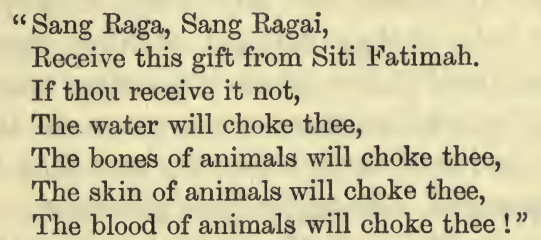

He then picked up the paddle and struck the water three resounding blows with the flat blade. "The crocodile will hear that," he turned to say, "and will come the sooner." He then pushed the bait about two or three yards away from the land so that it floated in open water, and carefully disposed the rattan-line along the bushes that fringed the island in such manner that none of it lay in the water. The end of the rattan was not fastened to anything, and the crocodile was free to carry off hook, line, and bait whither it chose, but whithersoever it might go the rattan would float on the water's surface and betray the presence of the crocodile. We placed the three other baits in suitable localities, and then had done all that we could do for the present. The 
sun was setting, and as he paddled back Manap explained that a gorge-bait is necessary and a snapbait impossible; even if, as sometimes happens, a crocodile seizes the bait the moment that it is put in the water it must be given time to swallow it, for the hook will find no hold in the bony cartilage of its mouth. What surprised me more than anything was the smallness of the bait; it seemed surprising that any animal addicted to carrying off cattle should deign to notice so insignificant a morsel as a chicken. "They will eat anything," Manap said"frogs or rats, if they can get nothing bigger."

We were back at the lake a little after sunrise the next morning, and as soon as we got near the place where we had set the first line we saw that the bait had disappeared. Manap's eyes glistened. He put everything in order in the canoe, pushed the boatpole, his enormous knife, and compendious basket into the bows of the canoe, and paddled gently towards the spot. Suddenly his face fell. "Misbegotten child of Satan!" he muttered. Then he turned to me, "See, it was not a crocodile, but a scoundrelly iguana that has taken the bait. There is the rattan still hanging on the bushes. A crocodile would have swum away to its retreat with line and all before it swallowed the bait." We paddled up and found that the "scoundrelly iguana" had taken the bait out of the water, dragged it a few yards on to the land, and had then stripped the hook clear, leaving nothing but the bare metal. There was nothing to be done but to coil up the rattan and take it away. Most loathsome animals are these iguanas, to call 
them by their popular name, though "monitor lizard" is their more proper name. They have wonderful powers of scent, and are always to be found near carrion. When sitting up for a tiger over a "kill," one often sees them; they come shambling awkwardly through the undergrowth, and after a careful scrutiny on every side tear huge mouthfuls of flesh out of the carcass.

We found that the three other baits had not been touched, and all that we could do therefore was to objurgate the iguana and go home to hope that a crocodile would soon feel hungry.

On the way back Manap told me the story of the feud between the crocodile and the monkey, to which he had alluded the day before.

"Once the crocodile's wife was very sick, and it seemed as if she would die. The doctors and sorcerers who were attending her declared that the only chance of her recovery was that she should eat a monkey's heart. So the crocodile set off in search of a monkey. He left the sea, and ascended a river until he met a monkey playing on the banks. The crocodile called to him, - 'Oh, Sir Monkey! who is the wisest and cleverest doctor in this land?'

"And the monkey of course said 'I am.'

"The crocodile then explained that his wife was very ill, and that he would be for ever grateful if the monkey would prescribe for her. An enormous fee was demanded and agreed to, and the monkey stepped on to the back of the crocodile, who at once swam away down the river. 
"When they got out to sea, the crocodile was so pleased with his skill and address in having duped the monkey that he could no longer keep the joke to himself. So he explained to the monkey that he was going to give his wife the monkey's heart to eat.

"The monkey, though he nearly died of fright, showed no outward signs of alarm. On the contrary, he said that his heart was entirely at the disposal of the crocodile's wife, but declared that it was a thousand pities that the crocodile had not explained his purpose earlier, for he had left his heart hanging on a tree on the bank where he had been playing when the crocodile had met him.

"He suggested that they should return to get the heart, and to this the crocodile, who realised that the monkey without its heart was of no use to him, agreed.

"Back they went, therefore, and at the bank where they had first met the monkey pointed out a tree and was allowed to land. He sprang ashore, and climbed to the top of the nearest tree, whence he screamed and chattered his wrath and defiance at the astonished crocodile.

"Ever since then the crocodiles and the monkeys have been enemies, and whenever a family of monkeys see a crocodile, they gather round him and ask him rude questions about his wife, and inquire whether he has lately met many monkeys' hearts hanging on the trees."

The same afternoon, when the heat of the day was over, we went out again and found another 
bait gone. Rattan-line and all had disappeared, and there was no doubt that it was a crocodile this time. We carefully examined a deep pool that lay close by, and then a second pool, and afterwards a third inner pool from which the others led, and here we found a piece of wood on which the bait had floated. There were marks of crocodile's teeth on it. At the farthest end of the pool we saw the end of the rattan-line floating on the water, and knew that the crocodile was at the other end of it. Decks were cleared for action: Manap was of course barefooted, and I took off my shoes and stockings so that my bare feet might have as good a hold as possible on the smooth bottom of the dug-out. Everything was pushed up into the bows except the barbed spear which was to play an important part in the proceedings. This spear was made on the same principle as a harpoon: a rope is attached to an iron spear-head, into a socket of which a shaft loosely fits; as soon as a blow has been driven home with the spear the shaft detaches from the head, and the stricken animal is held by the rope and the barb.

I stood up in the middle of the canoe, and the spear with its coil of rope lay at my feet. Manap sat in the stern paddling gently. As we approached the rattan-line glided away mysteriously. The crocodile had seen us coming, and, unconscious of the fatal rattan that marked its course, had moved into deeper water. I seized the line and pulled in the slack rapidly; in an instant $I$ felt the crocodile on the line, and jerked the line hard so as to snap the 
slender fibre bands round the bait and to set the hook free to catch in the crocodile's gullet.

Then I held on and drove the hook well home. The curious electric sensation that thrills a line when a fish is on it told that the crocodile was well hooked. At once it moved off into the deep water at the centre of the pool, dragging the canoe after it. The sensation of blind terror that the brute felt at the pain of the hook, and of the force that bound it to it knew not what, was plainly transmitted along the tautened line. For some few yards it sullenly resisted, as I slowly hauled in the line hand by hand. It was numb and sick with fright; but only for a few yards, and then it burst into a wild fury. For years it had been the tyrant of the lake, and, since it had left its native river, had never come into contact with anything stronger and more powerful than itself, and it would not yield the supremacy, much less its life, without a struggle. Wildly lashing the water, it turned to dive to the bottom and to break the rattan-line. I was brought almost to my knees, and had to pay out the line I had pulled in; and it was all that I could do to hold on to the end of the line while the crocodile towed us, canoe and all, towards the second pool. Again I hauled in the line with all my might, and Manap skilfully kept the canoe head on to the crocodile. In the contest I had the great factor in my favour that I had not so much to pull the crocodile up to the canoe as to pull the canoe up to the crocodile; but, on the other hand, my foothold in the unstable cockleshell of a canoe was not 
always as sure as might be desired. After a lengthy struggle I managed to get the crocodile within three or four yards of the canoe, and in the clear blue water of the pool we could see its yellow length under the canoe fighting and snapping at the line, and turning and twisting as it fought. But the sight of the canoe was too much for it, and with a desperate effort it tore the line out of my grasp until again only the end of it remained in my hands, and continued the struggle in the depths of the pool. Again I pulled in the line, and yard by yard it yielded. This time I saw that I could get it within reach of the canoe, and when it was within three or four yards of us, I handed the line to Manap, in accordance with a preconcerted arrangement, and picked up the spear.

"Stab it in the soft part of the throat, Tuan, or under the stomach, not in the back or sides; and stab quickly, for the line may be partly bitten through." With straining muscles Manap hauled on the line, and, swirling like "Ugudwash, the SunFish," the crocodile came up fighting through the water. As it came to the surface, the water that heaved and rocked to our exertions burst into a fury of foam. In the middle of the turmoil one could see four outspread claws with every nail outstretched, a swingeing, lashing tail, and a long flat head with open jaws; all were mixed into a horrid inextricable knot like the drawing of a Chinese dragon on a plate. For a second it straightened, and as it did so Manap hauled its head above the level of the water, and I had a clear view of a 
whitey-yellow throat, at which I stabbed with all my strength. Who is responsible for the traveller's tale that the crocodile's skin is impervious to steel weapons, and even to bullets? Under my thrust I felt the spear slice its way, parting the soft yielding flesh before it. The spear-head entered up to its hilt, and then I wrenched the shaft free from the socket and seized the coil of rope at my feet. Thus we now had a double hold on the crocodile-Manap holding by the rattan-line and hook, and I by the barbed spear and rope. If there had been a storm before, there was a tornado now. At one moment the open jaws would surge out of the broken water, and snap together in unpleasant proximity to our legs; the next moment the heavy tail would swing free of the water, and, lashing through the air with the cut of a flicking whip and the weighted swing of a falling tree, would hit the side of the canoe a blow that made it shiver.

More than once the taloned claws got on the gunwale of the canoe, and it seemed as if in the blind turmoil the brute would get on board. We were both drenched from head to foot in the water that flew in every direction, and the little canoe rocked so violently in the waves of the commotion that there was no small risk of losing one's balance and falling in on top of the raging brute.

"We have him too close to the boat," Manap shouted. "Let out more line!" We slowly paid out the two lines, with the result that not only was the struggle continued at a safer distance, but that the crocodile entangled itself in the lines. As 
it writhed and twisted and turned on every side and in every direction, the rope caught an outstretched leg on one side, made a loop round it, and then caught in a leg on the other side. As each limb was caught we let out more line, so that, while of course the line was always taut, there was sufficient length of it between the crocodile and ourselves to enable it to entangle itself still further. In a few minutes all four legs were caught, and the animal's struggles became less violent; for though most of its power lay in its tail, yet the legs were needed to balance the body in the water, and without this balance its muscular efforts became ill-directed and uncertain. Twice in its contortions the crocodile slipped the ropes from its legs, and the struggle began anew until they were again entangled. In the restraint of the entangling ropes the crocodile's efforts, though they increased rather than otherwise, had only a diminishing effect, and a few more minutes were all that was necessary. "I think that we can manage now," Manap said. We both pulled our lines in until the crocodile was a few feet from the canoe. "Will you take both lines-one in each hand?" Manap handed his line over to me, and picked up a piece of stout boxcord some three or four yards long with a running noose at one end of it. "Now hold steady with the line on the spear-head and pull hard on the hook-line, so as to bring his head as far as possible above the water." I followed the "directions, and as the open mouth appeared above the water Manap dexterously'slipped the noose over the animal's 
upper jaw and pulled it tight, some six inches behind the point of its nostrils. Then, snatching his opportunity, with a quick turn of his wrist he slipped the slack of the cord round and under the lower jaw. By pulling on the cord he could now bring upper and lower jaw together and close the animal's mouth. He then asked me to pull the crocodile closer into the boat. I did so, and for a part of a second the animal lay quiescent, with its mouth bound by the single turn of the cord. Like lightning, Manap in that time had twisted his wrist, and a second circle of the cord lay round the closed jaws. He draw the cord tight, and the teeth of each jaw pressed home into the sockets of the other. "Now pull his head over the gunwale of the canoe." As the long pointed head appeared over the side of the canoe Manap firmly seized it by the nostril. It seemed the maddest thing possible. Here was a brute that a few seconds before had been raging like a devil incarnate. We were still half blinded by the spray it had flung in our faces, and the dug-out still rocked in the waves its wild struggles had raised. For a moment it was still, and a cord was round its mouth; but the cord might so easily slip with any sudden movement either of the crocodile or of ourselves, and there was nothing to show that the struggle was over-far from it. One shuddered to think of what would have happened had the cord slipped. The hand that pressed so confidently on the brute's nostrils would be snapped and seized in a second, Manap would be taken overboard and 
worried and shaken like a rat by a terrier, and would drown before my eyes in the crocodile's embrace. But no such thing happened. Manap grasped the point of the long narrow head with one hand, and with the other rapidly wound the cord round the clenched mouth, ending it off with a half-hitch knot. The extraordinary thing was that while Manap did this, though the time as a matter of fact was only three or four seconds, the crocodile remained comparatively still. The front feet, it is true, clawed wildly at the canoe's side, but they could not reach Manap's hands. The surging, swirling turmoil ceased, and from the moment that the cord had just been slipped round its jaws the crocodile appeared to give up all heart. No sooner was the knot tied round the crocodile's mouth than Manap produced another cord and slipped it over a fore-leg. Pulling the leg up to the animal's side, he then slipped the line over its back and caught up the other fore-leg with it. He pulled the two fore-legs together over the crocodile's back as far as he could, and, passing the cord round them once or twice, tied it in a knot. With a third cord he noosed and tied together the two hind-legs.

"Sudah," he said. "That is finished."

What he had effected was perfectly marvellous. In two minutes he had transformed a ravening water-devil into a trussed-up monstrosity, and his only weapon had been three pieces of box-cord. The furious monster that, all open mouth, whirling tail, and outspread claws, had bent itself into strenuous coils like the Dragon of China, now lay 
long and limp beside the canoe. The tightly closed mouth and the legs tied awkwardly over its back made it look almost ridiculous. The fight was over. I held the rattan-line, and Manap paddled the canoe ashore. The crocodile did not make another effort. A deep groan burst from its clenched mouth twice or three times, and it allowed itself to be towed alongside the canoe like a dead thing. When we reached the edge of the lake Manap dragged it ashore by the golf-links and killed it with a few blows of a heavy wooden bar. It was between nine and ten feet long, and the clear water of the lake had given it a most beautiful bright yellow colour. The girth of its body and its weight showed that it had been feeding well, and as it had taken to attacking cattle it was time that it was caught. A man seized by it would have had no possible chance of escape.

Such was the taking of the first crocodile that Manap and I caught together. Though we often set baits for the other two crocodiles that were said to inhabit the lake, we never caught them. But in the old mine-holes round Taiping I caught many afterwards, sometimes with Manap and sometimes without him. The second time that I went out I took the cord myself to tie up the crocodile's mouth. It was one of the most exciting moments I have ever experienced. As in other hazardous enterprises that require some nerve, such as playing with poisonous snakes or making parachute descents, what one most needs in the first essay is the confidence that can only come from practice. 
On another occasion B. and I set some lines in an abandoned mine-hole near a big mine where some twelve or fourteen hundred Chinese coolies were working. A crocodile was hooked, and when the coolies saw us playing it at the water's edge, they flocked round us to satisfy their curiosity, and so thickly and so closely did they press upon us that we were nearly pushed into the water on top of the struggling animal. It was only by threatening them with the spear that I was able to keep the barest space around us. Another time S. and I set two lines in an abandoned mine at Kamunting, and when we returned the next morning could find no sign of them. We paddled round the water's edge and examined every inch most carefully; then we inspected a little creek that flowed into the hole, and followed it for half a mile or so. Not a sign of any rattan. We followed the creek where it led out of the pool, and went down it for about a mile. Again not a sign anywhere, and coming to the conclusion that some rascal of a Chinaman had seen the rattans and had stolen them, we returned home in disgust. About a week later a note was brought to me from the police-station to say that a Malay had come there with a crocodile, which he said he thought belonged to me. I went over at once to the police-station, and there saw one of my missing lines, and attached to it a young crocodile. The Malay's story was that he was cutting firewood in the forest about a mile from the pool in which I had set my lines, and had seen the rattan lying on the ground. He naturally picked it up, and was 
considerably surprised to find a crocodile at the end of it. It was a small one, and with assistance he killed it. Having heard of my lost lines, he naturally concluded that this was one of them, and brought it to the police-station. To his delight I told the police to pay over to him the Government reward for killing a crocodile. Nothing was ever heard of the other missing line. I imagine that both lines were taken by crocodiles, and that the animals, after swallowing the baits, had felt suspicious of the rattan-lines which followed them wherever they went, and had left the pool in the hope of getting rid of them. That the animal which the Malay came across should have been resting so far from water is remarkable; and that the two animals should have taken the baits on the same day, and that both should have abandoned the pool to wander overland, is extraordinary.

Sometimes one hooks a crocodile that is too big to be tackled. A crocodile more than twelve feet long has such weight and bulk and strength that it cannot be played from a boat without an undue amount of danger. "Have a rifle handy," was Manap's advice, "if you think that you have hooked a big crocodile, and play it from the bank if possible, for sometimes it will 'amok' and attack a boat. If the crocodile floats up to the top and looks over the water to see what it is that pesters him, then do one of two things at once: shoot him if you have a rifle, or else drop the line and go home. For the next thing that he will do when he feels 
the line again will be to dash at the boat and board it. And then what is one to do?"

In the Taiping Museum hangs a crocodile twentyfour feet eight inches long, and when one stands in front of it and pictures the scene suggested by Manap, one cannot but echo his question-

"And then what is one to do?" 


\section{S L A D A N G.}

The Indian bison, known to the world at large as the gaur, is called by the Malays sladang. ${ }^{1} \quad$ It is only found in India, Burmah, and the Malay Peninsula. There is a tradition in Ceylon that it formerly existed in the island but has become extinct, and this would seem to be true, for Robert Knox, who nearly two and a half centuries ago was a prisoner amongst the Cingalese for twenty years, gives in his "historical relation of the island" the following account of the "Creatures Rare in their kind"-

Here are also wild Buffalo's; also a sort of beast they call Gauvera, so much resembling a Bull that I think it one of that kind. His back stands up with a sharp ridg; all his four feet white up half his Legs. I never saw but one, which was kept among the Kings Creatures.

This description, though excellent so far as it goes, will bear a little amplification. A big bull sladang, the largest and noblest of all the splendid creatures of which the tribe of oxen and bisons is composed, stands eighteen hands, or six feet, at the shoulder. But it is the animal's massive bulk rather than its

1 Pronounce slă-dàng. 
height that is impressive. The fore-legs are short, and the body comes down to within two feet of the ground; at the shoulder, therefore, the sladang presents an expanse whose breadth and depth are most imposing, and suggestive of enormous weight and power. A big bull will weigh nearly a ton. The "ridg," to which Knox refers, runs from the point of the shoulder half-way down its back, where, with a sudden drop of about three or four inches, it disappears: it is caused by the elongation of the vertebræ above the spine, and, unless the eye can take in the noble girth of the animal, is apt to give it a somewhat "humped-up" appearance. Except on its forehead and below its knees, the colour of a bull sladang is a rich black, the hair being fine and sleek, and so short that the hide shows through it. The legs have cream-coloured stockings, which well set off the prevailing black. The hooves are fine and neatly shaped, and very small in proportion to the size of the heavy animal they have to carry-much smaller than the splayed-out hooves of the buffalo, which is a far smaller animal. The head is very broad, the distance between the eyes being exceptionally wide, and the muzzle is very square. The forehead rises between the horns into a high arched ridge, that gives the animal a peculiar look of lofty dignity, and this frontlet is covered with short, crisp curls of ashy-grey hair. Lower on the forehead the hair gets shorter, and at the level of the eyes gradually shades into the glossy black of the rest of the body.

But it is in the massive girth and shapely curve 
of the horns that the great beauty of the sladang lies. At their base, the base of an old bull's horns are deeply annulated and indentated, and covered with many scars and rugged pits that would seem to tell of much battering. The horns sweep out boldly from the brow, curving in again at their extremities; and in a most beautiful head, belonging to the first sladang that I shot, the distance between the points is exactly the same as the distance between the eyes - thirteen inches. These horns measure six feet and a few inches from tip to tip along the outer curve and across the forehead, and their circumference at the base is nineteen inches. But on the living animal the head looks small in proportion to the gigantic bulk of the body. It is the relatively small head and extraordinarily small hooves that give the sladang an appearance of high breeding, which goes far to make it so noble-looking a creature. The disproportion between the size of the head and the bulk of the body is so marked, that my disappointment at the head of the first sladang that I shot is still fresh in my memory. It was a splendid animal, exactly eighteen hands at the shoulder, and of enormous girth; but I had not seen a sladang before, and the head looked very small. T. and I were in the wilds of the forest of the Semantan district, and when we returned to the boat we sent his five boatmen to get the head and as much of the meat as they required. I was surprised to find on their return that it was as much as they could do to carry the head alone, and still more astonished to discover later that, 
with the luck of a beginner, I had obtained one of the finest heads ever seen in Pahang.

T.'s head boatman, whose visions of preparing a vast supply of sun-dried meat were dispelled, was seriously annoyed. "The meat is left in the forest while the bones are preserved in the house," was his scathing comment.

The Malays have, I think, an exaggerated opinion of the savage disposition of the sladang. They believe that it will often charge unprovoked, and they always take great care to avoid any place where fresh tracks are to be seen. But I have not heard of an authenticated case of an unprovoked attack, and in the instances where men have been charged unawares, the cause may perhaps be reasonably ascribed either to their stumbling upon an animal that was nursing a wound inflicted by some one else, or to their meeting the mother of a newly-born calf.

A wounded sladang is probably the most dangerous of all big game. Not only will it charge, but it will hunt down a man with the utmost vindictiveness and tenacity of purpose. Of this, a striking instance came under my notice in an inquiry regarding the death of a Malay in the Tembeling district. Two men had gone out to shoot sladang, and the survivor, who told the story, had wounded a bull. It charged him, and he tried to seek refuge behind a gigantic merbau tree, that, luckily for him, stood in a little open spot, unencumbered by undergrowth or creepers. But the sladang saw him, and came round the tree after him, like a terrier after 
a rat. Round the tree dashed the Malay, keeping an outspread finger on its trunk, and round after him came the sladang. He could not gain on it, and it could not catch him; but, as he ran, its jaws slobbered blood and saliva upon his back.

While the animal followed him with outstretched muzzle, its horns, of course, lay innocuous upon its shoulders; and the moment that it tried to get its head down to throw its horns forward into action, the circle in which the two ran was so small that the man gained ground. The other man watched this performance from behind another tree, and after a while rashly shouted to his friend to make a rush to another tree. The sladang heard the call, stopped, saw the man, and charged him straightway, goring him so that he died a few minutes later.

To corroborate his story, the survivor produced his coat, the back of which was drenched and clotted with blood and saliva.

Of the supreme courage of a sladang I once saw a striking instance when a bull, so badly wounded that it could only manage a shuffling hobble, preferred to charge me at this slow and painful pace rather than to die with its back to a foe.

When I was in charge of Ulu Pahang some years ago, sladang were comparatively common in the down river districts, but my official duties kept me so busy in the mining area up river that it was only rarely that I was able to visit that part of the country. I had no regular tracker, and when I could get away took with me as gun-carrier one of my boatmen, or a local Malay. 
On one occasion I was able to take advantage of some Government holidays, and as the long, hot, lazy hours of the afternoon were wearing away my houseboat gently drifted alongside a landing-stage at the village of Pulau Tawar.

There we tied up, and as soon as we had made fast my old friend the district chief came on board to hear my news and tell me his. I had intended to go on farther to Padang Tunggal, a plain some distance farther down the river, but he suggested that instead of that, the next morning I should go to a plain, some three miles inland on the opposite bank, which was periodically visited by a herd of sladang. As soon as I had decided to act upon his recommendation, he sent for his two local Malays, brothers named Saleh and. Yusuf, who had some reputation for tracking and shooting deer, to go with me as guides. The discussion which followed their arrival abundantly proved two things,-first, that we ought to arrive upon the plain at the first dawn; and secondly, that in order to do so we ought to start about two hours before daylight. This being the case, the two men, after some expostulations and promises, acquiesced in my demand that they should sleep the night upon my house-boat.

At three o'clock the next morning the alarum went off just as I was striking a match to see what the time was. I tumbled the blanket off me-for, though we were little above sea-level, and only three or four degrees north of the equator, the nights in the Malay Peninsula are cool all the year round-and pulled 
on my clothes while the crew and the servants bestirred themselves lighting lamps and setting a fire. Breakfast was soon prepared, and at about a quarter to four we were ready to start. The night was pitchy black, the sky weighted with heavy clouds, and the air full of the smell of rain. By the light of a lamp we lowered ourselves from the house-boat into a little dug-out that lay alongside. It was an unstable little craft at any time, but the darkness seemed to make it more perilously sensitive than ever to the slightest motion of an occupant. Hurricane lamp and rifle were placed in front of me, the Malays took the bow and stern, and then, with barely an inch of free-board, we pushed out into the full current of the broad, black, swiftlyflowing river. The stream swept us away, and the darkness swallowed up the house-boat. The Malays kept the dug-out in a diagonal line across the river, ever aiming at unseen points, below which we were ever drifting, and at last, after hard and long paddling, we made the farther bank. We landed safely, and then by the light of the lamp had to make our way along a path through the forest. Everything was very still in the darkness. Occasionally we disturbed some small bird that broke into frightened twitterings, and then after a sleepy chirp or two fell asleep again. Sometimes a cicada awoke to utter one sudden piercing shrill, to be followed by as sudden a silence; and now and again some brown thing would scuttle from under foot. After half a mile, made long and slow by the difficulties of the darkness, we emerged upon an open 
plain. It was covered with a strong rank growth of lalang grass that reached up to our waists. It dripped with dew. On every blade hung beads so full and so weighted that they could scarce hold to their support. As we forced our way through the long grass, the swathes bent themselves to the pressure of our bodies, clung closely and heavily to every curve and movement of the limbs, and, as it were in an agony of self-abnegation, rubbed off on us all the moisture that they carried.

In a minute we were wet through, and I had to transfer my cartridge-belt from my waist to my neck, and to hold my rifle above my head. And in the darkness of the night how cold the clammy wetness was. Long dead, fallen trees lay across the path at intervals, and over their trunks, covered sometimes with loose treacherous bark that slipped under our feet, we had to clamber. Smaller trees and unexpected branches formed every now and again painful traps to the shins of one or another of us. After a time we came to a little stream. This in its normal state was not more than knee-deep, but a local rainstorm at its source a few miles away had swollen it into flood, and now in petty vehemence it swirled almost breast-high.

The wet lalang grass had thoroughly chilled us, but this forest torrent was icy cold. As we lowered ourselves carefully from the bank into its black depths, toeing to find the bottom, it took our breath away. Holding lamp, rifles, and cartridges high above our heads, we had then to stem the rushing water, while step by step we felt for foothold among the 
loose boulders that strewed its bed. Though the stream was not more than a few yards wide, the passage was-in the darkness that our lamp but feebly pierced-far from easy or even safe. At last we stood upon the farther bank, dripping and miserably shivering. Our path continued through the plain for some little way, and then we re-entered the forest. A short walk took us to another plain, which was the place where we might expect to find the sladang. We were slightly before our time. There was a grey light in the east, but it was still so dark that an object at a distance of more than a few yards was invisible. The light increased momentarily, and as it spread higher and wider through the sky the grey grew clear and pure and ivory-like in a seeming transparency. The birds awoke to shake themselves and to utter their first morning twitterings, and among the tree-tops a family of gibbons called to one another in melancholy piercing cries. The nightjars, that had sat silent for the hours since midnight, bestirred themselves to swoop and circle, uttering their plaintive call, for a few minutes before they sought a shady shelter for the day. We could soon discern the line of forest that surrounded and shut in the plain. The ivory grey of the sky quickly turned to saffron, and the saffron to yellow. The yellow turned to gold, and then we could see the extent of the plain that lay before us. A light mist rose from the open expanse. It broke up into curling flocks, which blew lightly away with the first gentle breeze of morning, fading as they rolled over the tree-tops into thin steamlike streaks. 
Far away in the corner of the plain to our right I could see, in the still uncertain light, a brown mass like an ant-hill: then it moved a few paces, and we knew that it was a sladang. The first thing to be done was to test the wind. The direction taken by the mist showed that the little wind that moved was in our favour, but to make doubly sure I pulled out my Malay knife from the wooden sheath in which it hung at my belt, and peeling off a shaving or two from my thumb-nail watched the particles flutter to the ground. In a hurried consultation we decided that our best chance was to cross the open plain at the point where we were, and then to skirt along the forest on the farther side. Crouching low in the tall lalang grass, we made our way with little difficulty through the plain, and noiselessly crept through the forest undergrowth to make for a point whence I wished to get another view of the sladang.

We reached the spot in safety, and saw, some 300 yards away, two inagnificent animals grazing in the open plain. Now that it was daylight, they were seeking the cover of the forest, but, as it was yet early dawn, they walked quite leisurely, browsing as they went, moving forward a step or two at a time and stopping again to feed. Towards our left, some quarter of a mile away, the plain ran into the forest in a little secluded bay, and the sladang had their heads turned in this direction. I again tested the direction of the wind with a shaving from my thumbnail, and then we crept back into the forest to intercept the sladang. We had no time to lose, for the animals would certainly not remain in the open much 
longer, and any sudden alarm-a squirrel's chatter or a sudden meeting with a wild pig-might send them trotting into the safety and cover of the forest. On the other hand, we had to move in perfect silence, for every animal knows the risks to which the exposure of the open plain subjects it, and is doubly watchful.

Even when one hacks a path, it is not easy to make a way through the wild profusion and tangled thorny growth of a Malay forest. But when one is tracking one dares not use a knife, for the sound of the first chop would give the alarm. It is bad enough to have to crawl and creep and wriggle and struggle with every obstacle that thorn and spike can offer, but that is not all. Far from it. You see a bough barring your way. In its present position it is too low to be crawled under, too high to be stept over: you must raise it slightly with your left hand and then insinuate yourself underneath it. Your right hand holds your heavy rifle. While you are in this strained attitude, looking for a place where you can noiselessly set down your right foot, you see that the bough is covered with red ants, which ran down to it from their nest on the parent tree the moment that your touch communicated the alarm. Their little black beady eyes gleam with fury, and their red mandibles are open to their widest extent. They carry the after part of their bodies high in the air, so that the slim waist is strained almost into a right angle, and they seem to writhe in a frenzied anticipation of the moment when the time to bite will come. You cannot draw back : you must go on, and you cannot afford to 
wait. An ant or two runs up your wrist, while others bide their time, waiting until you are under the bough to drop on to you. One bites at your coat, but missing the responsive twinge of sentient flesh, races over you until it finds the nape of your neck. Here it stops, and gives you a bite so full of formic venom that it feels more like a sting than a bite; and though you have been expecting it, you cannot help wincing. The ant holds on in fury, the mandibles, legs, and forepart of the body so tightly clenched to your skin that they are almost motionless, while the after part of the body wriggles convulsively to put more force into the bite. Other ants bite your face, or dive into your hair to bite your sealp. Suddenly you find that an ant has found its way down your neck under your vest, and has run on until it has reached the small of your back. There, when retreat is impossible and death certain, it bites and bites and bites until you kill it. And then, when you attempt to pluck it away, often you pull it in two, and leave the head hanging on to the skin in which the mandibles are embedded.

But the ants are not as bad as the leeches. Walk you never so lightly, the weight of your footsteps gives the news of your approach, and upon the leaves and grass-stalks and the decaying vegetation that lies everywhere underfoot, the brown forest leeches stand up in eager anticipation. They are of all sizes, from the baby that is scarcely thicker than a thread to the full grown one of an inch and a half long. They stand on their tails, swaying their bodies and bowing their heads on every side to discover the direction from which the sound comes. They have a quaintly fantastic, 
mincing appearance, from which the Malays borrow a simile to express the affected walk of the damsels of their country.

But when a leech sees the object of its search there is no further delay-no more bowing and curtseying; it races towards its goal. The head is thrust out as far as it will reach, and the mouth seizes hold of whatever it may touch, a leaf or blade or the bare soil. The body is bent into a great loop that brings the tail up to the head. Then the long body straightens again, and the head is thrust forward once more. Each step is the full length of the body, and the leech covers the ground in graceful sinuosities that remind one of galloping greyhounds.

And when the leech gets on to you it wastes no time. Should there be no opening at the top of your boot, and should the folds of your putties afford no entrance, it climbs until it reaches the place where your knickerbockers button at the knee. This is the place where it generally finds access. But it is immaterial to the leech where it gets at you : get at you it will. If every other opening is unavailable, it will, if not picked off sooner, climb until it reaches your neck. The sense of smell seems to be strongly developed in these pests, for when your blood begins to flow after a leech has dropped off you, gorged and pearshaped, all the leeches that get upon you subsequently make their way to the one place. Sometimes you may pick off a handful of leeches that hang in a cluster, all clotted with gore and slime, round the side of your knee, and find that you have only three or four other leeches on the whole of the rest of your body. 
It adds to the difficulties of attempting to pick a way over a carpet of fallen twigs and crackling leaves, when you see that a leech is racing to catch your boot. In another two or three strides it will reach you. To move your foot before you can seize hold of it may mean that you may snap a dry branch underfoot, and alarm the animal you are stalking; to let the leech get on to you, means that unless you stop to pick it off it will leave a punctured wound upon you that will cause you some days of considerable irritation; and to stop to pick it off may mean that another leech, or perhaps two, will take advantage of the delay to climb upon you unawares. Among your winged worries are mosquitoes, horse-flies, and an occasional skirmisher from a wasp's nest.

I well remember the leeches in this patch of forest, for one of the bites ulcerated, and some months elapsed before it was cured. When we got to the forest edge I got on my hands and knees, and crawled until I could peer over the plain. What a sight it was! Instead of the two sladang that I had seen, a herd of eleven of these magnificent animals was quietly grazing in the open plain in front of me. Not thirty yards away, and just opposite to me, were a couple of bulls. A huge gaunt cow was a little distance behind them, and beyond her-the farthest of all-but not more than seventy yards away, was the big bull of the herd. A smaller bull and some cows with calves were feeding a little way apart, and somewhat to my right. The little bay or inlet, where the plain ran into the forest, was slightly to my left. The wind blew from them to us, bringing a faint odour of the sweet rich fragrance 
of cattle. Only once have I had a sight of animal life that could compare with this herd of sladang; and that was when a Malay and I were alone in the depths of the wildest forest - far from any human habitation -and at midnight saw a great solitary wild elephant taking a bath at a sulphur spring, peacefully drinking and besprinkling himself, while the moonlight poured down through the silent trees and shone upon its black glistening body and long gleaming tusks.

But I had little time to watch this herd of sladang. The big bull had his head in the air, and was staring in my direction over the ridge of the gaunt cow's back. As he seemed suspicious, I was afraid that he had seen us move, and made haste to fire before he should give the alarm. How clearly I see it all-the great noble head, the grey hair upon the brow, the glossy jet black of the rest of the head, the massive size and shapely curve of the horns.

I only saw his head, for the gaunt cow covered the rest of him, and, aiming to shoot clear of the cow, I aimed too high, and-missed.

The whole herd dashed away to my right, leaving in the first alarm the little bay for the open plain. The four animals in front of me presented their broadsides, but the big bull was hidden by the cow, and I was unable to get a second shot at him. With my left barrel I fired at one of the other bulls. Then suddenly the sense of the dangers of the open plain overcame the first panic, and the whole herd turned sharply and, with the big bull leading it, galloped back again over the open plain, making for the nearest cover, which was the opposite point of the little bay. They 
were not more than a hundred yards away, and broadside on.

I turned for my second rifle to Saleh, who had been standing close behind me when I fired. But to my horror I saw that he had slipped away a yard or two to one side of me; and, even as I turned, I saw him fire both barrels into the air high over the backs of the galloping animals. I reloaded my own rifle as quickly as possible, but before I could get the stock to my shoulder the animals had reached the cover of the forest. It was all over. I turned again to Saleh, who was reloading the rifle, and, now that the madness of the moment had left him, was looking somewhat sheepish in anticipation of my displeasure.

But I could not trust myself to speak. It was bad enough to have missed such a shot at seventy yards, and to know that the chance of a lifetime had presented itself only to be thrown away; but it was far worse to feel that there had been such an extraordinary opportunity of retrieving a failure, when the big bull's great shoulders had offered so easy a shot as he galloped by at the head of his herd, and that this wretched man had spoilt everything by his miserable imbecility. It was not as if I had not told him what to do, I said to myself miserably. It was not as if he had not known perfectly what he had to do. If there had been any possible good in what he had done, one could have stood it; but to think that he had senselessly, uselessly, loosed off both barrels into the sky! It was excruciating. I realised helplessly that the big bull and the herd that had been so close to me were still galloping 
madly, scattered in several directions, through the forest. Though they had passed out of earshot, I knew that they were still crashing their way through every obstacle, and that it would be hours before they recovered from even the first shock of the firing. It was out of the question to follow them.

But as the herd had wheeled about in its gallop through the plain, I had seen the bull, at which I had fired with my second barrel, leave the others and turn away to the right, alone. I told Yusuf to take the gun from Saleh and to give him the lantern and luncheon case instead; and then the two men followed me into the plain. We soon found marks of blood.' When the rest of the herd had turned, the instinct of the wounded animal had led it to leave its fellows, and to nurse its pain and wound in seclusion. We followed the tracks in gloomy silence. As we left the plain to enter the forest again, the unhappy, disgraced Saleh spoke to me for the first time.

"Pardon, but there is something that we should do before we follow farther."

I stopped, and he explained what he wanted to do. Plucking a couple of leaves from the nearest tree, he folded each leaf in two, and slipped one into the other, so that the fold of the top leaf enclosed one half of the lower leaf, and the fold of the lower leaf enclosed a half of the top leaf. Then with a small twig he pegged the leaves into a footprint of the wounded animal, and muttered over them a charm to prevent the sladang from turning to charge us. The folding of the leaves is symbolical, and is the expression of an idea that is common to many coun- 
tries. An insect that crawled along the folded leaf from its stem to its tip would find itself, at the end of the journey, no farther than it had been at the beginning. In the same way the animal against which the charm is directed is supposed to be unable to advance, and to be forced to retire by the way that it had come. The shape of a horse-shoe conveys the same idea. The shoe that is so often nailed to the stable or the dairy door in English farmyards is placed there to turn back any fairies and sprites that might cause mischief among the horses or cows. The superstructure of a Chinese grave is built in the shape of a contracted crescent, in order to repel any evil spirits that may attempt to enter the tomb. And the folded leaves are supposed to prevent the big game of the Malay forests from charging its pursuers. We followed the tracks for some little distance, going slowly and carefully through the thick undergrowth, for we knew that we should probably be charged. On every side, where the thickets spread a leafy covering over the darkness that they enclosed, and the tree-trunks massed closely one behind the other to intercept the line of vision, we tried to make out, pausing between each step, the form of the great animal we sought. At last I heard its heavy laboured breathing. I crept up cautiously, and saw it lying down. As it leapt to its feet I fired, and it fell, struggling in the convulsions of death. The Malays saw that it was helpless, and rushed upon it to cut its throat before the breath of life should have departed.

When this was done, and the sting of the "might- 
have-been " somewhat deadened in the comparative success of the day, Saleh found a fit time to make his apologies and excuses.

"I could not help it," he explained; "when your gun said rap, my gun had to say rap too. It would not be resisted. I was wrong, and any punishment that is inflicted I will undergo. But-but I did it because I could not help it."

The appeal was irresistible: not that I had any desire to resist it, and we made friends again. The Malays produced their inevitable cigarettes-coarse Java-grown tobaccco, wrapt in the inner skin of a palm-leaf,- - and we sat down to discuss the points of the dead animal. They both considered it a matter for congratulation that I had shot this young bull rather than the old patriarch. To soothe any bitterness that they imagined might, despite the final success, still remain at the thought of the preceding failure, they explained to one another, for my benefit, that the flesh of the old bull would have been far too tough. This animal was exactly right, just young enough to be still tender, and just big enough to provide meat for every one. Of course, there would have been more to eat on the old one, but without doubt things were far better as they were. The difference in the size of the trophies did not enter into their calculations, but the memory haunted me of those grand horns and that massive head.

Saleh turned the conversation to the subject of the charm of the folded leaves, and having, with all the deftness of a folk-lorist stalking a folk-tale, invited my confidence by telling me all about its meaning, 
asked me in return to impart the nature of the charm that I had used when I had peeled the shaving from my thumb. I am afraid that it was in vain that I explained that I had only wished to test the wind, and in vain that I assured the two men, in reply to further questions, that it had nothing to do with preventing the sladang from taking alarm or from winding us; and I should not be surprised if to this day they believe that an interesting bit of European hunting lore had on this occasion come under their observation, and that the secret of it had been jealously preserved and kept from them.

After a short rest we finished our cigarettes and returned to the river to get men to cut up the carcass. It was nearly midday, and the open lalang plain through which we had so painfully stumbled in the darkness was baking in the sun. The dew had long since evaporated, and the grass blades stood stiff, hard, and dry. Long wavy lines of heat rose from the plain and quivered against the background of a cloudless sky. Dragon-flies, iridescent and bejewelled, poised themselves over the grass, or, darting with crisp, crackly noises, hawked for wasps and flies. Rosy-breasted swallows circled overhead, and beeeaters, with gorgeous plumage of purple and green, were making short flights with sudden upward swoops to catch the dragon-flies.

On the topmost branch of a small shrub, conspicuous by its isolation in the middle of the plain, an extraordinary bird called a crow-pheasant seemed to be drying itself in the sun. Its tail and wings were spread out to their fullest extent, and every feather 
seemed either to be awry or on the point of dropping out. One felt sorry for the ungainly and awkward appearance of the poor thing, which looked like a very dilapidated and badly stuffed pheasant; but any sympathy was misplaced, for, in reality, it was showing itself off for the benefit of a mate which lay hidden on its nest in a lalang tussock close by.

When we reached the bank, the great Pahang river, so dark and fiercely flowing when we had crossed it in the little dug-out not many hours before, lay at our feet, a broad, smooth, untroubled sheet of silver. 


\section{THE LIGHTS OF CHANGKAT ASAH.}

ON the west coast of the Malay Peninsula, between the Perak and the Selangor rivers, lies the great Bernam river. The Perak river is thickly populated, and steamers and launches churn up its tidal waters every hour of the day. Near its mouth are large sugar and coco-nut plantations, and a railway runs inland to feed the busy mining centres where tens of thousands of Chinese coolies work, like yellow ants, to dig out the tin-ore that affords the greater part of the world's supply. It is the same in Selangor. But the Bernam river lies untouched. At its mouth a fishing village, evil-looking and evil-smelling, huddles on either bank: then the great river sweeps inland; it is navigable to steamers for a greater length than any other river in the peninsula, but an occasional Government launch is the only vessel that disturbs its waters. About a hundred miles inland it opens into a vast, dreary, dismal morass, named Simpang Kadangsa, and loses itself in a wide spread of floating vegetation through which the Malays with trouble hack a way for their boats. Above this horrible pathless expanse it is a clear mountain stream flowing through magnificent forest, inhabited 
only by herds of elephants and numbers of rhinoceroses. Near the hills from which it takes its source, at a place where the stream is little more than knee-deep, one suddenly comes upon a Malay village of considerable size. It is a lovely spot, and its beauty is intensified by its contrast with the sombre forest from which one emerges: a wide plain of crisp springy turf, grazed short by buffaloes and cattle, with coco-nut palms waving over the brown thatched houses that fringe the river-bank, and padifields covered with the rich and tender green of the young rice-plants.

Tin-ore was found in small quantities in the hills behind this village, and the consequent immigration necessitated a magistrate being stationed there. I was sent there in 1895, and Tanjong Malim as I knew it was a purely Malay village.

My quarters were placed on the river-bank, and facing the house, a little more than a mile away, a hill named Changkat Asah rose abruptly from the level plain that stretched out on all sides around it. The cultivated area extended to its base, but thence to its summit, some 700 feet high, it was clad in virgin forest. The huge dark mass dominated the beautiful village at its base. It was of course the feature of the place, and an object of superstitious dread to the Malays. Many were the stories told of the spirits that dwelt there, and no searcher of rattans or gutta dared to remain on its slopes after dark. Every Jin and Efrit known to the Eastern mind; the malignant demons that change their form at will; the familiar spirits of sorcerers; ', heads of 
women that roam the forest to suck the blood of men; the Voice-Folk whom all can hear and none may see,-every kind of spirit lived on Changkat Asah. The mass of stone that forms its highest point was said to be a bilek hantu, "a spirit's room." The Malays believed that this formless mass took shape at night; and men have told me that the lights in this meeting-room of the spirits might occasionally be seen from the plain below.

Some twenty years ago the Trigonometrical Survey Department wished to have the summit of the hill cleared for an observation station, and, as might be expected, experienced the greatest difficulty in getting any Malay to take up the contract. Finally a foreigner from Sumatra - a man named Baginda Sutan-was induced by the high price offered to undertake the work. He persuaded some other foreigners from the states of Kedah and Kelantan to join him, and at first they climbed the hill every morning to their work and returned before dusk. But they thus lost half their day's work, and after a while Baginda Sutan asked them if they were prepared to sleep on the hill. This, though he made light of the local reputation of the hill, and pointed out that hitherto they had met with no supernatural obstacles, they absolutely refused to do. As no promises of higher pay would move them, Baginda Sutan decided to shame them into compliance, and announced his intention of staying on the hill the next night by himself. He felt confident that after a night or two, when nothing had happened, his men would be encouraged by his example, and that they 
would all sleep on the hill, and be able to put in a full day's work. The next day, therefore, when the Malays returned down the hill in the afternoon, Baginda Sutan chaffed them cheerily for a lot of cowards, and remained behind hard at work felling a tree. When the men returned next morning they found only a raving lunatic.

The contract not unnaturally terminated abruptly, and when, some years later, I came to Tanjong Malim, the Trigonometrical Survey Department was still without a station on Changkat Asah. I saw Baginda Sutan once by chance in a Malay house, and thus heard the story of his fate. The poor man, who had once been a flourishing energetic petty contractor, was in a state of absolute idiotcy; and never since the day that his terrified men had conducted him down the hill, had he been able to give any account of what he had experienced.

Soon after my arrival an officer named B. was sent by the Survey Department to put up a station on Changkat Asah. He employed Javanese coolies, and at first lived with me, climbing the hill daily with his men until they had put up a shanty for him and another for themselves. He then went to live on the hill while superintending the clearing of the site and the erection of the station, and the fact of his being a white man gave his men sufficient confidence to follow him. Two or three days later he tottered into my house. Never have I seen a man in such a state of absolute collapse. Ghastly white, as if all the blood had been drained from him, with shaking hands and trembling mouth, he told me his story. 
I hasten to say that it had nothing to do with the supernatural inhabitants of Changkat Asah; his adventure had been with a tiger. On Changkat Asah his apology for a house consisted of palm-leaf walls, a split palm flooring, and a palm-leaf roof. It was built on the side of the hill close to the summit, and the slope of the ground was such that, while on one side the flooring was on the level of the ground, on the other it was some two feet above it. His Chinese servant occupied a small lean-to, which was built a few feet lower down the hill, and his Javanese coolies lived nearly two hundred yards away by the source of a small stream whence they got their water-supply. The second night that he had slept on the hill he had been awakened by some animal breathing and moving outside his shanty, but, imagining the sound to be that of wild pigs, had turned over and gone to sleep again. The next morning his coolies pointed out to him the tracks of a tiger that had walked round and round him during the night. He had no weapons with him, and very foolishly did not think of sending down the hill for any. He went to his day's work forgetting all about the matter, and at night went to bed without a thought of any danger. Soon after he had gone to sleep he awoke with a start and heard the tiger close beside him outside the house.

His mattress lay on the floor close to the wall, on the side near the summit, and here, as I have said, the floor was on a level with the ground outside. The tiger was on this side of the house, on the rising ground above him, and only a few feet separated 
them-a few feet and some palm-leaves loosely strung together. His first idea was to make a rush for the door on the other side of the house, but this he did not dare to do, for fear that the tiger hearing him attempt to decamp might forget its caution and jump in upon him. He therefore lay motionless and shouted for his Chinese boy to bring a lamp-but then, getting a sleepy answer from the boy, unluckily told him to hurry up, as there was a tiger outside. After that the boy not unnaturally refused to move, and so B. lay there on his mattress absolutely defenceless and in the dark. When he had shouted to the boy the tiger had kept quiet, but as soon as he stopped shouting he heard it again. He heard the tiger smelling at him, and the sniff-sniffing of its nostrils as it tried to take in all that there was to be smelt, in the same way that a hound snuffs up a stale scent or tries to make out what some strange food may be. The heavy fetid breath of the animal was over him, and the deep body sound that is half purr half growl vibrated in his ear.

Again B. shouted until he had to stop for want of breath, and again the tiger kept perfectly quiet. When B. stopped shouting, and lay with gasping lungs and throbbing heart, hoping that he might have frightened the animal away, he would hear after a minute or two a gentle sniff outside which told that the tiger was still there. Again he would yell as long and as loud as he was able, but all in vain; when his voice ceased, he would hear the quiet sound outside, within perhaps two, perhaps three, feet of him-not more-patient as the mouse within the wainscoting, 
imminent and awful as death incarnate. The wretched man soon despaired of making himself heard by the coolies in their shed below : they were a considerable distance away, and as they were on a lower elevation, B.'s voice did not reach down to them through the heavy forest. There was nothing to be hoped for from the Chinese boy, who had seen that his best chance of safety lay in perfect silence-though, poor wretch, he too would probably have been glad to have been able to relieve his feelings by yelling. Let those who, under like circumstances, would have carried unarmed a lamp from one house to another accuse him of cowardice.

B., though he had no hopes of obtaining assistance, had no option but to continue shouting as long and as often as he could, for the brute outside seemed to gain encouragement, as evidenced by deeper and louder sounds from anythinglonger than a momentary silence. Twice he tried to rise stealthily from his mattress to make a rush from the door, but, though he attempted to cover the sound of his movements by his shouts, the creaking of the light flooring betrayed any movement, and a savage growl warned him to desist. Though in this agony of mind and utter physical exhaustion, B. was, he said, beset by a curious difficulty: he was at a loss for words to shout. $\mathrm{He}$ had to shout to keep the tiger from leaping in upon him, and he could not shout unless he could think of something to articulate. He had ceased to call for his men, and for hours yelled furious orders to the tiger. Finally, as hour after hour passed by in the alternations of the paroxysms of the man and the subdued 
contented sounds of the tiger that held him at its mercy, he was so wrought that, without hope of any chance of life, he shouted out at the top of his voice the prayers he had learned as a child. Every time he ceased for want of breath it seemed as if the strength to begin again would fail him. More than once he was tempted to hasten the end he felt could not be far off by getting up from his bed and thus bringing the tiger upon him. But this he could not bring himself to do. In this way the poor man passed the night. He first heard the tiger at about nine o'clock, and it was not until the day began to break that it left him.

After hearing B.'s story, I decided to go up the hill with him and to wait for the tiger that night. In the afternoon two Malays came up with us and tied up a goat outside the house in which B. had slept, making a seat for us on the trigonometrical station that was being erected a few yards away. I was surprised at the tracks outside the little palm-leaf house: the tiger had walked up and down, up and down, beside the house, and deep prints showed where it had lain facing the place on the bed where B.'s head had been. The two front paws were within two feet of the bed, and the impression showed that the tiger had been there for many hours. The palm-leaf wall was so flimsy (any cat could have jumped through it) that the only human reason for B.'s marvellous escape must be that the tiger had imagined the house and its inhabitant to be a trap like those often set by the natives, and, though obviously hungry, had lacked the courage to put it to the test. Our men returned down 
the hill, and after an examination of the paths leading to the place we climbed into our seats. It was about five o'clock, and the sun was dipping to the western forest. The cultivation and clearing that formed Tanjong Malim lay all open at our feet. On every side it was shut in by forest: to the east it ran up to the great densely-timbered mountains that form the main range of the peninsula; to the south it continued miles upon miles towards Selangor; to the north the same featureless expanse of heavy-leafed trees extended to Perak; and to the west it swept away past the hill on which we were to the low-lying hills of the Wild Dogs, and beyond them to the wide pathless swamps of Simpang Kadangsa. In the midst of this sombre dark-green sea of eternal forest, like a jewel fixed in some plain setting, lay the beautiful clearing of Tanjong Malim. Several bends and stretches of the Bernam river lay clear and cool in an atmosphere permeated by the setting sun, and in the far background gradations of light and shadow showed its valley and its source in the distant mountains. The village seemed to be almost at our feet. Every house stood distinct, and we could clearly hear the "moo-ah" of the buffaloes, and the barking of the dogs. Beyond the small row of shops was the policestation, beyond it my quarters, and a path from the village led past my house to the mines farther up the valley. As the sun sank over the mountains a little breeze sprang up and alleviated the heavy heat of the day-time, and then, as the Malays say, "the day turned to become night." As evening approaches a little breeze, wandering imprisoned among the tree-trunks, 
like a disembodied creature, blows chill upon one's cheek, and there is an eerie feeling of expectancy that will not be dispelled from the mind of any one who is alone at this time in the forest. The darkness increases rapidly. It seems to settle down among the tree-tops in layers, and to sink thence slowly to the ground, falling like black, impalpable snow and shutting out the light above. Even at sunset I doubt not that Baginda Sutan felt that he had been over daring. One knows that at nightfall the animals whose tracks may be seen on every side, but which themselves are rarely seen in the daytime, will be moving in search of food. The great tree-trunks stand like enchanted giants, and seem only to await some signal to escape from the charm that binds them. Again the little damp breeze puffs upon the belated Malay, and this time it seems to have been blown by some unseen mouth. The animals that have slept all day are stirring now, and he cannot but doubt that so too are the spirits. A shadow seems to move from one treetrunk to behind another, and as he turns his head suddenly towards it, he sees at the side of his eye other shadows move at the spot from which he has just turned. Then, as it gets darker, everything around him alters its appearance; where stood a bush now looms the shadowy form of a rhinoceros, and something with the outline of a tiger crouches at the foot of a black tree-stump. The more his eyesight strains, the less real does the object on which he gazes become, and lights and spots dance and flicker beside his eyes. Curious squeaking, chirping noises become more frequent as the darkness increases, and as they cannot be defin- 
itely assigned to bird, frog, mammal, or insect, suggest a supernatural origin; and if by chance any of the awful eagle-owls scream-uttering an ear-piercing yell, like that of a woman suddenly seized and tortured-the nerves of the man are strong who can repress a shudder, and the Malay would be rare who would not think that it was connected in some way with the forest spirits. When night had closed in, and the darkness prevented any possibility of retreat, it cannot but be that Baginda Sutan bitterly repented him of his foolhardiness.

The lights of the valley below us twinkled brightly. We could see the outline of the village streets, the police-station, and my quarters, while little specks of light marked the scattered houses up and down the river-banks. The unlappy goat, after a few plaintive bleats, followed at intervals by heartrending and consumptive coughs which seemed to be directed at us, settled itself to sleep and silence. The moon was in its last quarter, and would not rise until past midnight. So we sat lonely on our peak waiting for the hours to pass. Suddenly I saw two lights far up the Bernam valley hurrying down towards the village. "Fight among the Chinese in the mines," was my comment; "and here are two men coming down to the police-station to make a report." We watched the progress of the two lights down the valley, seeing them pass the miniature blaze that marked my quarters and go on towards the police-station on the river-bank. Then in an instant the two lights Hew up into the air, and rushed straight at us. So fast did they fly, and so directly did they aim at us, that 
before we could realise that they were not the lamps of Chinese miners clamouring far below us outside the distant police-station, two great balls of light sped by within fifty feet of us. To say that we were frightened is to put it lightly. I gave a gasp, and but for the support at my shoulders would, I believe, have fallen backwards out of my seat. The suddenness of the assault was overwhelming. From our lonely eminence we had watched the lights making their way down the valley, my interest tempered with thoughts of the court case they might portend for the next morning; and in a second, even as we watched them, the tiny lights had turned to fiery globes of the size of a man's head, and their speed had become almost that of a cannon-ball. However, as our visitors passed us, we saw that they were natural phenomena, and either chemical gases or electric fluids-that is to say, they were either of the nature of a Will-o'-thewisp or of a St Elmo's light.

These two lights seemed to us to have arisen from the marshes above the village. Thence they were gently borne by currents of air down to the riverbank, where they were caught by the night breeze and carried up to where we sat. Soon after several more came drifting down from both sides of the valley towards the river-bank, and all, as they reached it, were seized and whirled by the wind in all directions. Before long there were over a hundred to be seen. The wind was fickle and variable, and sometimes a dozen of these balls of light, which were now all round us, would fly down the river together and meet others floating lazily by: 
they would play round one another as though in doubt which way to take, and then a current of air would come eddying round the hill and catch them up and hurry them out of sight. When the wind dropped and there was perfect calm, six or eight would rise, moving in and out among one another as if in some game, and mount up through the air, playing and dancing until they became small bright specks, then slowly sink, revolving and interlacing, until again a breeze would spring up and send them flying helter-skelter up or down the river. We noticed that the lights as they moved were not quite round, but slightly pear-shaped. Thus one rising would have a tapering tail below it, making its outline something like that of a balloon with a car, and one falling would have the tail above it. I imagine that this shape is caused by the pressure of the air upon the moving body. Thinking of this curious shape, I realised what we were watching. The dancing and flying lights were the spooks known as penanggal. The Malays believe that sometimes when a woman dies in childbirth she becomes a penanggal, and that at night her head, with a short part of an entrail, breaks from the grave and flies through the country, flame-coloured and with open mouth, to suck the blood and life of any man who may fall within its power. "That which is detached," is the literal meaning of the word. The head with its gruesome appendage can only detach itself at night-time, and must return to the grave before daybreak; and if it should lose its way, or become caught in any thicket so that it is overtaken by the light of day, there is 
an end of it. It falls to the ground or remains held by the thorns, and the passer-by sees it thereno longer luminous and nebulous as at night-time, but in the materialised form of the head of the woman that had been. It was, I' have said, the peculiar shape of these balls of fire that made it flash upon me that they were penanggal, and we could then understand the terrors of Baginda Sutan when he found himself alone on the hill-known and feared by all as the home of spooks and devils, -and saw himself surrounded by numbers of these unholy phantoms. What was really a wonderful and beautiful sight meant to him a diabolical orgie at the meeting-house of the spirits; and he must have looked upon himself as lost and doomed to a lingering death amongst these horrible graveyard ghouls.

All night long the lights beguiled the tedium of our vigil, for they did not disappear until a saffron light over the eastern mountains heralded the coming day. Damp with dew, and chill and stiff, we clambered down from our seats. The wretched goat awoke and bleated at us reproachfully. We had not seen nor heard anything of the tiger; and the goat had thus been luckier than it knew of, while we had seen something far more interesting than any tiger, and therefore did not take it much to heart. When we emerged from the forest path at the foot of the hill, and were making our way through the padifields, we happened to meet the district headman, Haji Mustapha, who was, under me, the chief Governinent official of Tanjong Malim. I told him of what we had seen, explaining how we had first observed the two 
lights come running down the path above my house. "By the Mercy and Grace of Allah," he exclaimed, "you have been marvellously preserved! Penanggal in truth were they; for know that the direction from which those lights came is that of our old disused burial-ground."

The question is, What were these lights? They certainly seemed to us to come up from the swamps of the valley, and this would point to their being of the nature of a Will-o'-the-wisp, which is only marsh-gas, $\mathrm{CH}_{4}$, a chemical compound of carbon and hydrogen. But in England, at all events, a Will-o'the-wisp is a small, feeble, flickering light hovering only a few feet (if so much) above the level of the marshes. These lights, on the other hand, were the size of a man's head, shone with a phosphorescent glow, and, as they passed over the summit of Changkat Asah, were at least 700 feet above the level of the plain. Perhaps they were St Elmo's lights. The objection to this is that St Elmo's lights are supposed to be caused by an electric disturbance of the atmosphere, and are generally stationary, attaching themselves to a fixed point like the masthead of a steamer; whereas the night on which we saw these lights was clear and bright, and, as I have said, the lights flew upon the wings of the wind. I cannot say what they were. If they were composants-the sailor's name for St Elmo's lights, and his corrupted form of the words corpo santo (holy body), - there is a curious parallel between the superstition of the British sailor and the Malay.

I never saw the lights again; and neither did B., 
though he spent some weeks on the hill. The tiger roared close to his camp a few nights later, and he and another officer in the Survey Department sat up for it several times without success.

No other European that I know has seen these penanggal, but Malays have told me that they have seen them; and the people of Tanjong Malim agreed that these must be the lights that were occasionally seen on Changkat Asah from the village.

I wish I knew what those flaming balls were. But of one thing I am certain: when we watched those flying and dancing lights, we looked upon that which had robbed Baginda Sutan of his mind. ${ }^{1}$

1 Since writing the above I have seen the following account by $\mathrm{Mr}$ Andrew Lang in the 'Illustrated London News' :-

"I am well acquainted with the set of lights which are often seen by the people of Ballachulish and Glencoe, villages on the south side of the salt-water Loch Leven (not Queen Mary's fresh-water Loch Leven), on the west coast of Argyllshire. They are bright lights which disport themselves on the north side of the loch, where steel' hills descend to the level, and to the road along the level, leading to the head of the loch. They rush, as it were, along the road, then up the hill, then down to the water edge, and so on, and are visible, not only to the Celtic natives, but to the English tourist. The ground is not marshy, even on the level, and the phenomena, though doubtless natural and normal, have not yet found a scientific explanation. They are not what people call ' corpse candles,' and a local myth used to attribute them to the agency of a dead laird-an explanation in itself improbable, and now abandoned as inadequate to the facts of the case."

These Loch Leven lights would appear to be the same thing as the lights of Changkat Asah; and I have been tempted to rewrite the paragraphs about the Will-o'-the-wisps and St Elmo's lights. On the whole, however, I prefer to leave my account as I originally wrote it. 


\section{T A P I R.}

VERY few men have shot a tapir, one of the chief reasons being that very few have considered it worth while to take the trouble. Its size does not entitle it to inclusion among "big game" in the proper sense of the word. It is inoffensive, and, though it can inflict a severe bite, is not, even when wounded, in any way dangerous. It has no trophies, and no spoils of market value. There is, therefore, little inducement to seek it, and the few European residents of the Malay Peninsula who care to give up their time and money to big-game shooting, devote their attention to news of elephant, rhinoceros, sladang, and tiger, and trackers seldom think of bringing information of so inglorious an animal as a tapir. Some possibly would not even turn aside to follow its fresh tracks should they come upon them by chance in the forest. On the other hand, the men who do not aspire to big game, and, contenting themselves with deer and pig, hunt with dogs, seldom visit the localities where tapirs are to be found; and as they do not attempt "still-hunting"-the American expression for the silent tracking and overtaking of an unsuspecting 
animal,-have little or no chance of seeing a tapir except by some rare accident.

But though the tapir carries no trophies, it is not without a fascination of its own. When one has a little imagination, what can be more interesting than to follow through vast gloomy forests the tracks of an animal that is one of the oldest mammalian forms,an animal that once existed in England, where fossil bones, practically undistinguishable from those of the living species of to-day, are found in the Miocene deposits of Suffolk; and an animal of a date so much earlier than that of the hippopotami, elephants, and rhinoceroses that once roamed through the valley of the Thames, that in the days of the Pleistocene period, when they played and fought on the river-banks, it had already become in England as extinct as they are to-day.

When one follows its tracks one can see imprinted upon the ground the history of its incalculable antiquity, for the front foot has four toes, and the hind-foot has only three. That is to say, the tapir, in its efforts to leave the primitive five-toed type, has only succeeded in discarding one toe of the fore-foot and two toes of the hind-foot. It is, therefore, a stage behind the rhinoceros, which has three toes to each foot; and both are far behind the horse, which has arrived at the irreducible minimum of a single toe. Long before the days of the hipparion, the threetoed ancestor of the horse, the tapir existed in its present form ; and while the three-toed horse evolved through countless generations, species after species passing away to be replaced by a form more nearly 
approaching the one-toed ideal, the tapir has remained unchanged. A rhinoceros-like animal, with the aweinspiring name of titanotherium, a contemporary of the tapir in the Miocene period, also reached the stage of having four toes to the fore-foot and three toes to the hind-foot. The titanotherium has passed away, but the tapir is still with us.

Then, too, the tapir's little proboscis, a mere elongation of the upper lip and snout, with the nostrils at its extremities, seems to be only an early rudimentary effort to attain a feature which has reached such high development in the elephant. It is true that it is useful to pluck a bunch of leaves or a tuft of grass, but it gives the animal the ridiculous appearance of wearing a false nose. Weirdly primitive, too, is the coloration of the Malay species. The head, shoulders, and fore-feet are a jet glossy black, the body is pure white, and the hind-legs are jet black. The two colours do not in any way melt into one another where they meet; on the contrary, the line of demarcation between the white and the black is most boldly and vividly drawn.

At its birth the baby tapir, a most laughable little caricature of its ungainly parents, is striped from head to foot with narrow bands of yellow and brown. ${ }^{1}$

${ }^{1}$ In this respect the young tapir resembles the young of the wild pig, an animal with which, inasmuch as the one is an odd-toed and the other an even-toed animal, it is in no way connected. The stripes are particularly interesting, for the theory of recapitulationnamely, that in the embryo and young of an animal is recapitulated the history of that animal's evolution - would lead us to believe that the adult tapir was once striped, and therein resembled other members of the odd-toed group, such as the zebras and, perhaps, the primitive horses. 
After a few months the young tapir loses its stripes and assumes a marbled mottled coat, which later becomes covered with irregular spots of black and white. Gradually some of the black spots turn white, and some of the white spots turn black, until eventually the adult animal assumes the fantastic particoloured coat which I have described, and which can best be imagined by picturing to oneself a gigantic black pig with a white sheet pinned round its body. Yet the extraordinary thing is that, despite this weird marking and strong contrast of colour, the tapir in its native haunts is not a conspicuous animal. In the heavy forest which it inhabits, where the chequered light and shade fall irregularly, it seems as though the shade darkened the whiteness of the skin, while the light mitigated its blackness, and when the animal is alarmed and seeks safety in flight, black and white melt into one another to form a strangely invisible grey - the grey of a fleeting mist. It takes the two strong colours to produce this effect, for if the animal were really the grey that it appears to be, it would, in its surroundings, be almost as conspicuous as if it were white.

I was stationed at Ipoh, the principal town of a large tin-mining district in the state of Perak, when my attention was first drawn to shooting a tapir. It was a miserable place for sport, for almost all the big game had been driven out of the district by the woodcutters and charcoal-burners, who ransacked the forest to supply the tin-miners. A sladang or two, it is true, remained in a secluded corner; there were a few rhinoceroses within reasonable distance; and tigers, 
though shy, were not uncommon. But the number of head of game was very small.

My official duties kept me in court throughout the week from Monday morning until Saturday midday, and it was not easy, therefore, for my tracker Malias to arrange the time and the place together. He was often able to come and tantalise me by a story of an animal within comfortable reach, so far as distance was concerned, but inaccessible until another three days should pass and Saturday come round. And then the usual result would be that we devoted the whole of Sunday to tramping through a forest in which we could find nothing more recent than fourday-old tracks.

After a long series of disappointments, Malias suggested that we could break the run of luck by shooting a tapir, which, he said, we should have no difficulty in finding. There was a number of tapirs scattered through the district, but we had never thought of going after them. Malias, however, had in his mind a particular animal that frequented a sulphur spring near his house. Jenali was the name of the place, and at one time, before the district had been opened up by roads and railways, and overrun by prospectors and miners, it had been visited by every kind of big game; but now they had all been driven away, and the only animal that still dared to resort thither was this solitary tapir. It seemed, however, to make amends for desertion of the others by its constancy, for, according to Malias, seldom a night passed that it did not drink at the spring. 
The following Sunday, therefore, we set off to seek the tapir. Leaving my house shortly after daybreak, we drove some three miles along the Kuala Kangsar Road, a magnificent highway that forms part of the main trunk system of the state. Through the suburbs of Ipoh, the road was thronged with rickshaws and bullock carts; at a level crossing we had to pull up while the express for the north clanged past. A few minutes later we met a file of elephants, moving with solemn and majestic pace along the strip of grass that lies between the road metalling and the drain side. At a whirl of dust in the distance, they stepped with quiet dignity into the drain, and turned broad backs upon the indecent turmoil and offence of a motor-car, driven by some European or Mongolian barbarian. Near the third milestone was a little roadside shop kept by a Malay, who catered for the simple necessities of native housekeeping, and for the luxuries of passers-by, whose dust-racked throats demanded such products of Western civilisation as orangeade and rose-champagne. At this shop we stopped. The mare was taken out of the trap, and, while the sais walked her up and down to cool, Malias unpacked the rifle. I buckled on my cartridge-belt, and he packed the sandwich-box and water-bottle in a cloth, which he disposed sideways on his back in the awkward Malay fashion, which is to pass the cloth enclosing the bundle over the right shoulder and under the left arm. After a few minutes' gossip with the shopkeeper we started for the sulphur spring. Following a native track for a 
mile or two through secondary forest, we came to the Pari river. This we crossed by a primitive bridge, consisting of a series of shaky poles resting upon insecure posts. A mile farther on we came to a little opening in the forest, where some enterprising Chinaman had boldly ventured to find alluvial tin, and had lost his capital. In the middle of a few acres of felled timber, which was fast being covered and smothered by a dense growth of entangling vegetation, was the pit, some fifteen yards square, in which his money had been sunk. It was now full of water, to which the clayey soil lent a colour of a weirdly unnatural blue, a dull dead turquoise. Like a glassy eye, it directed an unresponsive stare at the brilliant sky above it. Beside this chill pool stood the abandoned coolie-house, a tottering ruin. In the high grass that grew beside it, we found some old tracks of the tapir, which had found something palatable in the alkaline taste of the refuse-soiled earth around the kitchen. From this point we proceeded slowly, for we were not far from the sulphur spring, and it was possible that the tapir, after wallowing and drinking there, might turn its steps in our direction, in which case we might, if unawares, stumble upon it, or might pass its tracks unwittingly, and later suffer one of the most annoying experiences of a tracker, to find the tracks some miles farther on, to follow them patiently, cautiously, warily, and then, after an infinity of ungrudging toil, to find oneself at a place where, gaily tramping down a path in the gladness of the early morning, with eyes full of what the 
day might bring forth, and heedless of the signs upon the ground, one had passed, and overlooked, these self-same tracks. We found no fresh signs, however, and after a while left the little path. Malias pointed out the general direction that we were to take, and I gently opened a way for ourselves through the tangle of the forest undergrowth. Soon we came upon a path made by the tapir, and, following this cautiously, found the ground open suddenly into a narrow, swampy valley. Through a marsh, in which thick reeds and heavy grasses grew, a little stream wound a tortuous way. At our feet, under an overhanging rock, it ran through an unsavoury, inky-looking sludge. This was the sulphur spring of Jenali. It seemed a fetid little pool. The leaves that had fallen in it were heavy with a black, slimy deposit, and a sulphuretted odour clung to the soil, and even to the surrounding trees.

Here we found fresh tapir tracks. The animal had come down in the early evening, and then, after drinking and wallowing, had fed through the swamp grass in circles, returning three; or four times in the night to seek in the strong mineral deposit a corrective to the rich lush vegetable diet. The tracks were like a tangled string: loops of various sizes were drawn into a tight knot at the sulphur spring, and we had to find the end of the skein,- that is, the route by which the tapir had left the place. We spent some time in following tracks that appeared to be taking us directly away, only to find that the tapir, unable to resist the temptation of the sulphur spring, had turned once more to its 
fascinations. At last we found the end of the ravelled skein, and then for half a mile followed the tracks along a wood-cutter's path. The animal, having once made up its mind to go, had walked steadily along the path without stopping to feed. After a while it turned aside to ascend some rising ground. For some time we followed the path that it made for itself through the thick forest undergrowth, and then, after we had left the sulphur spring some two or three miles behind us, saw that the tapir had begun to dawdle and to pluck such young shoots and leaves as had tempted it. The distance that we had travelled had been covered very slowly; for, apart from the necessity of making our way as silently as possible through all the obstacles that the dense undergrowth of a tropical forest can offer, the hard, dry ground had made tracking difficult. By this time it was between ten and eleven o'clock. Before long we came to a place where the tapir had lain down, but not finding itself comfortable, perhaps, had moved on again. We were almost certain, therefore, that it was asleep somewhere close by, and the greatest care and silence became trebly necessary. In tracking a herd of animals that are feeding one may move fairly freely, for the noise that they themselves are making will generally prevent them from hearing the sound of any snapping twig or crackling leaf : even a solitary animal, if walking or feeding, may miss an accidental sound, but a solitary animal lying down will take alarm at the slightest thing. We moved with the most elaborate caution, therefore,--every step being 
carefully considered and thought out. And at every yard we peered through the dense foliage to discover anything that might be the black and white of the tapir.

But before we had gone much farther we suddenly heard the sound of an animal in flight crashing through the forest some forty or fifty yards in front of us. We could see nothing, of course, for the forest was so thick that even at half the distance we should have barely caught more than the most fleeting glimpse. There was nothing that we could do. We stood in silence until the sound died away in the distance, and then, somewhat disheartened, followed up the tracks.

The great, wide-splayed marks where each outspread toe had cut deep into the ground showed the frantic haste of the first panic. Gradually, as the pace slackened, the spread of the toes and the depth of the impression decreased, and before we had covered half a mile the tracks regained the normal appearance of the animal's usual walking pace. We traversed some gently falling ground, and then came to a swamp. At its edge the water was knee-deep, and as we waded in we found a treacherous bottom of rotten soil and tangled roots that cheated the feet and turned the ankles. Gaunt, starveling trees grew at intervals, and from the water's edge to a height far above a man's head the swamp was covered with a dense mass of mengkuang palms, whose leaves, shaped like claymores, but eight or nine feet long, are covered with double rows of saw-like teeth. Through this we 
painfully made our way, and emerged upon the farther side, where we found ourselves faced by a small hill. We reached its summit, and continued along it for some distance. We had no idea how far in front of us the animal was, and had to set our pace as best we could, avoiding impatience on the one hand and over-caution on the other, mindful of the Scylla of carelessly disturbing the game and the Charybdis of progressing at a slower rate than it. After some time we heard the alarm again, the sound of the headlong flight through the forest undergrowth, but again no call or cry of alarm. Then suddenly there was a heavy crash, then another, then another, a series of crashes, and then the sound of a tremendous bump. The direction and nature of the sounds told us what had happened. Somewhere in front of us there was a ravine, and the tapir's blind flight had taken it headlong down it.

"Quick! quick! he has fallen," urged Malias, pushing past me as, in my haste to follow, I caught in a tangle of rattans. But I could not move. I had fallen into the clutches of an enemy as beautiful as it is vicious. A delicate-looking tendril, light as the air upon which, far flung from the parent stem, it bent in a graceful curve; bare for half its length, and all along the lower half lovely with a wealth of slender drooping leaves; strong as wire, and armed throughout with rows upon rows of hawk-like talons, - had seized me by the shoulder. As I stooped to free myself, two other airy tendrils, agitated by the pull upon their stem and vindictive as hornets, leant forward to dig a row of claws into my topi and my 
bare neck. My topi was plucked from my head and flung into a thicket, but the hold upon my neck was fast. It was useless to struggle: to have done so would only have meant being caught by other fronds that, with all the beauty of kittens at play, swayed toward me with every movement that I made. Keeping as still as I could, I had to lop off with my knife such tendrils as I could reach, and then endeavour to unhook myself from the grip of the bands upon my neck and shoulder. And all the time Malias, who did not see my plight, maddened me with a senseless reiterated "Quick! oh, be quick!" After a moment of desperate calm I freed myself, and having paid toll in the form of a long tear in the cloth covering of my topi and a row of little jagged punctures on my neck, ran quickly forward.

We soon saw what had happened. The tapir, when startled by us, had run for some twenty yards, and then a steep ravine had interrupted the way. Down this it had gone headlong. Saplings, rattans, creepers, everything had given way before it; for, luckily for itself, it had not run into a tree of any size, and it was only a thick tangled clump of rattans that, by receiving the impact of the fall and by acting as a buffer, had saved it from a broken neck. We got to the bottom of the ravine as best we could, and heard the tapir moving slowly, and apparently painfully, in front of us not more than a hundred yards away. It was quite hidden from sight. That ravine contained as murderous-looking a mass of twisted trees and knotted creepers as one could wish to see. Every inch of stem and branch and twig of every 
growing thing seemed to be studded with spikes and hooks. I think the very roots had thorns. And every gnarled and knubbly tree had interlocked its branches with those of every other tree; while sinuous coils of rattans, enwrapped in thorny sheaths, bound altogether into a compact and solid whole, which offered a resistance as unyielding as that of a barbed-wire entanglement. To move forward even a step was a matter not only of difficulty but one that called for considerable ingenuity : ten or perhaps fifteen separate branches, creepers, or rattans would bar the way, and it was necessary to decide which one would pull down, which press down, which shove upwards or sidewards, and which, in such silence as was possible, one would slice through with the heavy knives we both carried. Sometimes the opening would look clearer to right or to left, and hope would lead us thither; but generally we found that, after a comparatively open space of a yard or two, we were confronted by a thicket so impenetrable that it seemed better to retrace our steps and try to find some other way.

Although the tapir was so close to us, we found it impossible to catch it up, and within half an hour it was obvious that it had been moving faster than we were. We also saw by the impression of the feet that it was not even going lame, and that our expectations of its having broken a limb had not been realised. After following the tracks for some distance farther, we reluctantly came to the conclusion that there was no chance of seeing it again that day, and therefore decided to return home. 
On the following Sunday we returned to the sulphur spring of Jenali, and again found fresh tracks; but again only succeeded in disturbing the tapir's slumber, and in driving it in headlong flight through the forest. And after that, two or three times a-month, - whenever, in fact, there was no news of bigger game elsewhere,-Malias and I went to the sulphur spring. We seldom failed to find fresh tracks, but for some months did not catch sight of the tapir itself. Between the two of us, though we were somewhat apprehensive of being laughed at by others, our lack of success became rather a joke, and we always talked of the animal in a friendly spirit of possession as "our tapir."

After a week's work in court, hearing interminable cases from Monday to Saturday,-endless civil suits except during my criminal assizes, long lists of criminal cases except in my civil sessions,-it was good to get away, even for one day, into the vast forest, which, although traversed by wood-cutters and charcoal-burners, retained much of its pristine mystery and wonder. And in the pursuit of the tapir there was added to the charm of the forest the fascination of following the tracks of an animal of the Miocene period, a contemporary of such fearsome creatures as the titanotheria-an animal, in fact, that might well have become extinct ages before ever the first semi-human man was born.

Almost every Sunday that we went after the tapir the same thing happened. Leaving my house at daybreak, we arrived at the little roadside shop at half-past six; by half-past seven we were at the 
sulphur spring; and between eleven and one o'clock we came upon the sleeping tapir.

We were never able to get up to it before it had lain down for its siesta, and we invariably disturbed it before we came within sight of it. Sometimes a nodding tree or waving branch showed the line of its flight, but that would be all. Once we were close behind it, when it plunged into the Pari river and crossed to the farther bank. It would have been especially interesting to have seen it then, for we might have learned whether it swam or whether, as the South American species is said to do, it walked upon the bottom of the river-bed. How far we followed the tapir after we first disturbed it would depend upon many things - the time, the distance, the heat or the rain, and, more than all else, the degree of our patience.

Sometimes the tapir was alarmed by getting our scent, and sometimes by a sound we made. Regarding the scent, we were unable to do anything; we could only follow the tracks, and as it was impossible even to guess at the line the animal was taking, or where it,would lie down to sleep, it was out of the question to make any détour if we found the wind unfavourable. As to the sound, the difficulty was not so much underfoot as in working a silent way through tremendously heavy foliage. But, nevertheless, I paid every attention to my foot-gear. Malias, like every Malay, was barefooted, and walked with ease on a matting of prickles and thorns. I tried india-rubber shoes, but found them too slippery on greasy ground; then I tried long stockings made of 
stout canvas, but found that they had all the disadvantages of a boot with none of its advantages. I even tried going on my bare socks when we discovered that the animal was close, but found that I had to devote an undue amount of attention to my feet. After many experiments, I decided that for silent tracking nothing that I could find beat a pair of stout English leather boots with plenty of big nails.

Our knowledge, derived from the tapir's tracks, of its habits was that it left the sulphur spring a little before daybreak, moved away through the forest for an hour or two, then fed, and afterwards lay down to sleep from ten to three o'clock. The length of the midday slumber depended very considerably upon the weather and the season, and it was sometimes broken up into two siestas, with a short interval between them. At three o'clock it moved away in the direction of the place it had chosen as the site of its evening meal and drink. This was almost invariably the sulphur spring, where it generally arrived an hour after sunset. Here it would drink, feed, wallow, and sleep at intervals until the first grey light of early dawn.

Malias was anxious to build in a tree over the spring a platform from which I could shoot the tapir at night. But this I would not hear of. One of the unwritten laws of big-game shooting, and one which is not always sufficiently followed, is that every animal should be attacked in the most sporting way possible. No one would attempt to take with a worm a salmon that could be tempted with a fly. The same principle applies to big game. No one should 
shoot from a platform in a tree an animal that can be driven or tracked, and no one should drive an animal when it can be tracked.

Tigers, for instance, leave no impression upon the ground, and, as they cannot therefore be tracked, may be driven, or, failing the possibility of a drive, may be shot from a tree. Pig and deer are not always worth tracking, and may therefore be driven. But tracking - "still-hunting" - is the highest form of big-game shooting, and should not therefore be discarded for the lower forms without strong and sufficient reason.

We knew that we could not come up with the tapir before it lay down for its siesta, and admitted that it was hopeless to attempt to surprise it in its sleep: the only solution of the problem was, therefore, to arrange our start so as to come up with it after it had awakened again in the afternoon. But when I suggested this to Malias, he pointed out some obvious objections. Even if we arrived at the place where the tapir had slept a few minutes after it had left it, we should only have three hours of daylight for tracking, and might easily be benighted. Of this, however, I decided that we must run the risk: we could take torches, and by this time we knew the lay of the forest fairly well. Malias' next objection was that even if we did get a shot and merely wounded the animal, we should not have time to follow up the tracks. His greatest objection, however, was one of which he said least, and that was that it was not the custom to begin tracking in the afternoon. In a land where they have a proverb, 
"Custom encompasseth all," innovations are not welcomed.

The next Sunday we did not start until midday. At about three o'clock the tracks brought us to a little gravelly stream not more than knee-deep. We crossed this, and followed up a well-beaten path that the tapir had used regularly in coming to and going from the sulphur spring. On the hard ground it was very difficult to track; there was a number of footprints, leading in both directions, and of every age - days old, weeks old, months old. And from these we had to distinguish the lightly superimposed fresh prints that we were following. Before long we both suspected that we had lost the fresh tracks, and were following up a stale trail. We accordingly went back to the little stream, and cast round to discover where the tapir had left its usual path. We could discover no other tracks, however, and therefore returned to the beaten path. Soon we saw that we had undoubtedly lost the fresh tracks, and again went back to the stream. We walked in its bed down-stream for some little distance, and then discovered that we were doing exactly what the tapir had done.

Lower down we found the tracks where it had left the water, and hurried up the bank to follow on, for we had lost some little time on the stale trail. We had not gone more than a hundred yards when we heard the well-known sound of the tapir crashing through the forest.

We stood still to listen.

Then Malias gasped. "He is coming this way!" 
A grey form burst through the undergrowth not more than twenty yards away, running, it seemed, blindly. Its pace was a lumbering gallop, the head being held low between the two fore-legs that were flung high up and far out in front of the body. It passed by us broadside on. The first bullet from my rifle hit it too high in the shoulder, but the second dropped it dead.

And our long quest of many months was over. We examined the tapir's weird features, its ridiculous little proboscis, its bizarre colouring, the strangely numbered toes, whose tracks we knew so well,--and then we fell to discussing the extraordinary chance that had led the tapir's flight in our direction. An inspection of the ground showed that a curious thing had happened. The tapir had been returning to the sulphur spring along the beaten path, which we had followed when we had gone astray on the stale trail, and had there come upon our fresh tracks. This it was that had alarmed it." It was from the danger presented by our tracks that it was running, and its blind flight had led it up to us. As Malias put it, it was a singular case of "turning from the corpse to clasp the ghost."

I have already said that Malias had never approved of my idea of starting to track in the middle of the afternoon. Our success in no way appeased his sense of the violation of the "custom," and he was glad to find an opportunity of having a quiet hit at me.

"Well," he said, "when we chance to kill our game in the morning time, we can find use for the sunpicture-box [my camera]; but if in future we go 
shooting in the evenings, it may perhaps be necessary to buy a box that will make pictures by moonlight."

The sun was sinking fast, and we were hurrying to make our way back to the main road to seek assistance in removing the trophies, when we heard the calls of some Malays in the distance. We answered, and they soon came up. Luckily they were rattancutters, and their heavy knives soon hacked off the head and feet, which we carried back in triumph to the little roadside shop.

Towards the end of the next week Malias came to me to receive instructions for the following Sunday. He had no information regarding big game: the sladang had not been seen for some time, there was no news of any rhinoceros, and he had no suggestions of any kind to make. The sulphur spring of Jenali, of course, no longer availed us anything. We were therefore forced to come to the lamentable conclusion that there was nothing to be done on the following Sunday but to stay at home, and then for the first time we realised what a blank in our lives the death of "our tapir" had made. 


\section{A FISH-DRIVE.}

ScHools, railways, and foreign immigration are making the Perak Malays of the present generation a class of men very different from their fathers; and old Alang Abdullah was one of a type that is fast disappearing.

$\mathrm{He}$ and the men of his age saw the younger men hurry in to the towns and mining centres to pit their brains and energies against those of the immigrant Chinese and Indians; but they themselves stood back from the press and turmoil, and watching the fever of the money-getting around them with uncomprehending eyes, explained their want of understanding by saying that they were Orang Hutan"forest men."

Alang Abdullah had been born within a few miles of the spot where his present house stood; and all his life long he had never been any greater distance from it than he could cover easily on foot within two days. The year for him was one uneventful circle, marked only by the padi time, the fruit time, the rainy season, and the dry season. $\mathrm{He}$ was a Muhammadan, of course - " there is no God but Allah, and Muhammad is His Prophet"; and he would have 
died rather than renounce a syllable of the profession of his belief. He fasted most strictly throughout the month of Ramthan; and every Friday he attended the village mosque, where he heard the imaum read extracts of the Koran in the original Arabic,-a language of which neither the reader nor the audience understood a single word. He would have been horrified to hear that any person should say of him that a belief in the Spirits of the Forest and the Water had more meaning for him than had any teaching of Muhammad, but such was nevertheless the case. Among the Malays who live, remote from the civilisation of the ports and towns, in the upriver districts, where the villages are sparse and few and the forest vast and all-encompassing, the veneer of Islam is as thin as the pre-Muhammadan belief in spirits is deep: Allah and Muhammad are far from this life, and six heavens in six layers lie between their heaven and this world; but the Jins, the Dewas, and other demons and spirits, actually walk the earth.

To Alang Abdullah, Batara Kala and Hana Taskun, the great Water Jins, were very real, very terrible, and very present. He had recognised them riding by his house on the roaring December floods, and in the silence of the night he had heard the Earth Jins hunting and holloaing through the forest. Less than three miles from his house was a hill where one might chance upon the Voice-Folk, the spirits whom all may hear but none may see; and not many miles down the Perak river was a district named after the Demon Bota, where to this day the spirit deludes 
men into the forest with sights of gorgeous palaces and lovely female forms, and promises of feasts and delights, and leaves them when morn appears fainting or dying in some gloomy thicket close by the scene of the night's phantom pleasures.

The river ran by the door of Alang Abdullah's small house, and at the back of his holding lay the great forest; and the Jins were no farther away than either the forest or the river.

The old man was a pawang, and was skilled both in the casting out of devils when a sick person had to be treated for some malady, and in the propitiation of spirits when any enterprise or excursion had to be undertaken.

But the old order was changing; the hajis and the immigrant Arab sheikhs looked with disfavour upon his incantations, and they instructed the boys who attended the Koran classes to have nothing to do with his heathen superstitions.

In every way the country was not now as it had been. In his youth foot-paths and elephant-tracks had (other than the rivers) been the only means of communication between village and village. Then the British had come into the country, and bridlepaths and agricultural roads had soon taken the place of the native tracks. Later came the "great roads" with their metalled surfaces and iron bridges, and now there was a "way of the fire carriages." All had been change and progress. It had affected even his river, the great Perak river. He well remembered the institution of the Government ferry, when the first bridle-path had reached the river's 
banks on either side. Then the great trunk road was made, and hundreds of yards of pontoon bridging connected the two banks; and now, on huge frames of iron-work; the fire carriages screamed as they crossed the river safe above the highest flood level.

But all this progress had passed by Alang Abdullah and had left him on one side. He did not understand the white men, and he knew that they did not understand him. He was afraid of the Government offices with the punkahs, the peons, and the police, the Court-house where they shouted "silence," and the Land Office, where even the officials were hot and hurried.

He knew that his lot was far better than it had been. The days of slavery, of forced labour and forced contribution, were over: he recognised that the ways of the Government were good, but he did not in the slightest degree comprehend them.

In his mind (so far as he thought of it), he recognised the Government as a fact in exactly the same way in which he recognised the existence of telegraphic communication. But the ways of the Government were as much beyond his understanding as was the working of the telegraph.

His second son was a forest guard in the Forest Department, and his youngest son was learning English and qualifying for an appointment in the clerical service. Only Alang Abdullah was himself too old to learn the ways of the new régime. "A new custom and an old man," he would say, shaking his head.

The scene he looked upon called forth reminis- 
cences of the "old custom," for among the throng on the sandy bank of the Perak river below him, where in his youth no white man had dared to venture, some dozen Englishmen mingled with the crowd of Malays.

The occasion of the gathering was the great fishdrive which was to take place the next morning. Every year during the dry season, when the river was at its lowest, the datoh, the native chief of the district, organised a drive, and Alang Abdullah, ever since his father's death, had been in charge of the operations; for whatever the hajis and sheikhs might say, things had not yet come to such a pass that any one would think of attending a fish-drive unless the spirits of the wood and of the river were duly propitiated. To Alang Abdullah the fish-drive was by far the most important event of the year.

It was an animated scene down by the river. Some of the Englishmen had returned from shooting, others had been spinning with a minnow for the Malay perch, and some were swimming in mid-stream. The shelving bank was fringed with boats. There were craft of every size, from the tiny dug-out which carried a single occupant, and made its way through the press like a darting needle, to the huge be-flagged house-boat which lay anchored bow and stern. On the bare sandy stretch little clusters of Malays gathered round rice-pots and improvised fireplaces: others were hurrying on various errands between the boats and the datoh's house, and some were overhauling the casting-nets which were to be used the next morning. From a 
young raja's boat came the booming notes of the assembly call of the war-gong. Every one was wearing his gayest and brightest sarong-pink, and green, and yellow, and purple; every one was excited, and every one was happy.

Only old Alang Abdullah, standing on a bluff behind the river-bank and looking up to the range of mountains at the river's source, was uneasy. Until three days ago the whole month had been rainless, and the river had been so low that a man might wade dry above the hips from bank to bank, and so clear that the water flowing over its sandy bed seemed, but for its ripples, to be of molten glass. This was the condition of water requisite for a really successful drive. But in the last two days there had been heavy rain in the hills, and the river was now charged with mud and silt, and was running more than a foot above its former level. His disappointment was the more bitter because he had originally selected a day in the preceding week as a propitious one, and it was to suit the datoh's European guests that the day had been postponed. Ever since the day when the datoh had decided to have a drive, Alang Abdullah had made every offering that he knew to be acceptable, and had used every incantation and observed every mystic rite to keep the rain from falling until after the appointed day. But despite it all the rain had fallen: and if it rained again that night it would be impossible for the drive to take place. It was with a sinking heart that he eyed the lowering clouds which wrapped the mountains at the river's 
source, and from time to time muttered to himself, "It is not right; it is not right at all."

On an island in mid-stream thirty or forty men were busy putting the finishing touches to the enclosure into which the fish were to be driven. The drive was to begin some seven or eight miles up-stream, and a rope through which glittering strips of palm-leaf were threaded would be dragged through the water between two boats to scare the fish and send them down-stream. This rope is known as a relap, and when it reached the door of the enclosure the gate would be shut, and the imprisoned fish be caught by means of the ordinary casting-net.

Alang Abdullah had staked the river on one side of the island and thus prevented any fish from passing that way, and had decided to make his enclosure on the other side.

His original intention had been that the island and the river-bank should form the two sides of his enclosure, and then all that would have been necessary would have been a barrier at the lower end, and a barrier and an entrance-way at the upper end. But the swollen river had made him alter his plan. The water by the river-bank was now so deep that the barriers would barely show above water, and if the river were to rise another six inches the fish would escape over their tops. He had therefore been compelled to stake off this deeper water, and his enclosure now hugged the shallower waters beside the island, alongside of which it ran in a narrow strip. 
The enclosure was simply made: into the sandy bottom of the river stakes were driven a foot or two apart, and were firmly bound together with lengths of bamboo. From these hung "chicks" (blinds of fine split bamboo laced together with rattans), which men had been making for the past month under the datoh's house. The top of the chicks appeared a few inches above the surface of the water, and the bottom was firmly pegged into the sand of the river-bed; the chicks overlapped, affording no means of escape, for the fish rarely if ever attempted to leap over them.

At the lower end of the enclosure was a purse, known as a magun, which was built on the same principle as the ordinary crab-trap. The fish could find their way into it from the enclosure, but could not get out again, and round it the palisading was carried to some height above the level of the water, and was made of double strength.

The men worked with a will, and by midday the enclosure was finished, and in the early afternoon all the boats that were to join in the drive were poled up-stream.

By four o'clock they reached an island with a beautiful sandy bank, and here all the house-boats tied up for the night.

In the cool of the afternoon the majority of the Englishmen set about practising the use of the castingnet, for few of them had realised that it was the only weapon that would be used on the morrow, and fewer still had ever thrown one. Other men went in search of jungle-fowl, and some took out their rods again. 
Alang Abdullah went up-stream another mile or two to a spot which he had selected. Here he and the men who were to drive spent the night. His men disposed themselves to sleep as soon as they had finished their evening meal ; but he spent most of the night in burning censers full of fragrant resin, and in making small offerings to the Jins of the Water and of the Forest. He promised them further offerings of rice, and eggs, and limes should the drive yield a good catch of fish, and implored that they would assist him, and save him and his party from harm and mischief.

The next morning the men were astir early, and when they had had their morning meal Alang Abdullah drew the relap out from his boat. It was merely a long line of native rope; at intervals of about a foot strips of thin yellow palm-leaf were threaded into the line at right angles to it,- -and that was all. When the line was dragged through the water the palm-leaves whirled madly round, like windmill arms, and the unnatural appearance and weird glitter that were due to the sparkle of the river and the rapid revolution, were well calculated to strike panic into any fish.

With his final invocations, Alang Abdullah gave one end of the relap to his eldest son, and sent him with it to the opposite bank of the river.

He himself remained with the other end under the nearer bank. The line with its bright streamers thus stretched from bank to bank, a distance of some two or three hundred yards. Special men were then told off in boats to take poles and splash and thrust under the river-banks where the trees overhung the water, and where the line could not therefore be dragged. 
Then a row of boats carrying men with castingnets was arranged in front of the drag-line. Their main object was to add to the splashing, and the odd chance of catching some fish that might be breaking back was only a secondary consideration.

Soon the array was set in order, and amid the shouting of men and the booming of gongs the drive started away down-stream.

By eight o'clock the line of boats came in sight of the island where the house-boats were tied up. Every one on the island bestirred himself, and in a few minutes the palm-leaf awnings, under which the Malays had been sleeping on the sand, were pulled from their supports and rolled up; boat poles were brought'out,cooking-pots were shoved away somewhere out of sight, and by the time the drivers approached, the island, on which a large party of men had encamped, was abandoned. The drag-line was cut in two at the head of the island, and the drive continued in duplicate on either side of it. The house-boats naturally followed the wider stream, and as they swung out into mid-stream, each sounding the assembly call on its war-gong to take up their places in the drive, they were greeted with the Malay sorak or battle-yell. "Sorak," shouted old Alang Abdullah, "Whoo! Whoo! Whoo!" and a series of whoos, terminating in a final screaming "Whooi!" issued from his throat. Every man in the boats that were drifting down with the drag-line joined in the yell. "Reply! Reply! Sorak! Sorak!" shouted the datoh; and the men in the house-boats roared back a mock defiance, every man shouting the final "Whooi !" at the utmost pitch of his 
voice, and prolonging the sound until he strained his throat nearly to cracking.

At the bow of every house-boat stood an Englishman with a casting-net over his shoulder, and such as could not get the firm footing of these heavy craft betook themselves to those of the dug-outs which looked most stable.

There was really no necessity for them to commence operations at this stage of the proceedings, for, as I have said, the present object of the casting was only to scare the fish from the deeper pools, where they might not be affected by the glitter of the revolving palm-leaves on the drag-line and the surface splashing of the poles. Of course some fish might by chance be caught, but it would only be a few that might be trying to break back up-stream. The Englishmen's initial display was not edifying, for even those who could give the net some little spread when standing on dry land found it a very different thing on the unstable support of a dug-out. However, no one thought of the figure he was cutting, for every one was simply "at play." The whole party, from their point of view, was a schoolboy's game, and they entered into it just as they would enter into any other game that was going on, without caring whether they were good at it or not, so long as there was fun to be got out of it.

When one considers that these men were with one exception Government officials, and remembers the extent to which their race owes its position to its prestige, this schoolboy frolic without loss of dignity cannot but be striking. Not a single one of them could throw a net even moderately well, and the 
majority had only the barest notion of how it should be done. And of course every one of them knew that, judged by Malay standards of casting, he was making an exhibition of himself. The first net thrown fell with but a half-open spread, but a chorus of approbation went up and down the line. The second man's net hurtled into the air like a bag of buckshot let loose from a sling, and plopped into the water in a solid lump. The thrower was greeted by a volley of chaff from the other men, who feared that they would do no better, but the Malays, who made a perfect spread at every cast, had only encouragement for him. And the old Malay who was steering his dugout leant forward and said, "The flower is not yet full blown; but time may bring the bud into open blossom."

In contrast with the efforts of the Englishmen, watch the Malay. He uses the ordinary bell-shaped casting-net which a few years ago might be seen on any English river, and with which I presume most people are acquainted. His net is sixteen feet high from the summit of the bell to its foot, and the leaden ring of chains at its base has a circumference when at its full spread of nearly forty feet. He collects the whole of the upper part of the net into his right hand, holding it about two and a half feet above the leaden chains. He then raises it, shakes out any dead leaves it may have caught, and straightens the lines of the net until they all hang true. He disposes one-third on his right arm so that it covers his forearm and extends a little over the crook of the elbow which keeps it in position; one-third he takes in his right 
hand, and the remaining third he holds in the left hand.

As he stands ready and poised in act to cast, he is a magnificent subject for a sculptor. And now watch him cast. The curve of the movement starts from the waist, and a sweeping line of action rises to the right shoulder; then simultaneously there is a swing of the right arm, a turn of the left hand, and a swooping lateral movement of the right shoulder; straightway the part of the net that had been held in the right hand flies out horizontally over the water, followed by the part that had hung on the right forearm and elbow. As they fly out the left hand moves forward, and when held out in front of the body gives a fan-wise lateral motion to the meshes and checks them as they slip over the fingers, and thus gives the net its full spread. The sweeping curve of the right side of the net is given by the swing of the right hand and the right wrist; the full curve of the left side is given by the restraining action of the fingers of the left hand. As the net reaches its full spread it falls in a level ring upon the surface of the water. In a level ring it sinks at once to the river-bed. The thrower then slowly draws it in by a string attached to its summit: as he draws, the ring in which the net fell contracts, until, finally, when he is about to raise it from the river-bed, a solid mass of lead hangs together. Any fish that was inside the outspread ring when it fell in the water is now somewhere enmeshed in the net. The net is carefully brought to the surface and the fish taken out.

The flotilla drifted slowly down the stream. In the 
front line was the row of boats carrying the men with casting-nets and the men who were splashing with poles. Alang Abdullah, holding one end of the dragline close under one bank and his eldest son holding the other end under the opposite bank, formed the second line. Behind them came the rest of the people, happy and careless and holiday-making, watching the work of the men in front, excited by the sunshine and the water-borne boom of the gongs, by the laughter, the shouts, and the throng. Alang Abdullah never for one moment relaxed his anxious care: where the stream was deep he let the drag-line sink lower in the water, using all his skill and science to prevent any skulking fish from dashing up-stream under or over it. The pools were well known, and the nets explored them thoroughly; under the banks on either side, where the forest-trees came down and bent over the stream, the men with poles were beating and prodding and splashing. Suddenly a cry arises, "Sangkut! Sangkut!" The line has caught. Then there is a yelling and a shouting, The line has caught in mid-stream. Immediately the men who imagine themselves to be nearest the obstacle plunge overboard, and swim and dive to find the submerged line. Keep back the boats; back water; splash with your poles, every man of you; the line has caught, and the fish will turn back and escape up-stream. Overboard with you, sluggard; jump in and splash with your arms. Who is that sitting idly in his boat? Overboard with him!

Every one yells to every one, while two or three boats, deserted by every man that they had held, drift 
idly down-stream. Then amid the shouting and the splashing a little old man, with thin grey wisps of hair hanging over his streaming face, emerges from under the surface, and we see that he holds on to the end of the line. He pulls himself along it hand over hand up-stream, until he reaches the snag on which it is caught. Three or four men, swimming, leaping, and diving, reach the snag almost as soon as he. They lift the line clear. "All right; no harm done; it is clear ; go on." And on we go again.

Then a young raja uplifts his voice as he hauls in his net, and, carolling cheerily, holds it up for the inspection of the throng, with a silvery two-inch fish struggling in its fold. "Lu-lu-lu, I've caught the first fish," and every boat shouts congratulation and applause. But even as he turns the net round for all to see his prize, the little fish with a despairing wriggle slips through the meshes and falls back into the river. "Adohi! [alas!] adohi!" he cries in genuine dismay; and up and down the line condolence follows fast on compliment.

And so we went on. There was but little incident. Now and again the line got hung up on a snag or rock; occasionally a man caught his net on some submerged obstacle, and had to extricate it amid volleys of chaff; more than once a man fell or was pushed overboard. And after some time a few fish were caught at rare intervals in the casting-nets. By eleven o'clock the sun was very hot; the mists and rain-clouds that had brought the cool of the early morning had melted away, and a blazing sun striking on to an expanse of glittering water through a cloud- 
less sky of purest blue set our skins a-tingle. But just as the faint-hearted began to weary, a whisper went round of rice and curry. Soon dug-outs with steaming bowls were seen to leave the datoh's boat for the men with the drag-line, and then of a sudden the house-boats converged with one accord. Alang Abdullah only let go his hold of the line for a few minutes, and as soon as he had finished his bowl resumed his careful handling of the glittering line. The Englishmen put their nets aside, and, all dripping with water, devoted themselves to huge platters of piled up rice and innumerable little saucers and bowls of sambal and curry.

By the time that the meal was finished the flotilla turned a bend of the river, and we found ourselves within a mile of the enclosure. We saw that the head of the island was thronged with Malays, and their gongs rang back a challenge to ours. "Who is for the water?" shouted our host the datoh. As he called he plunged in, and before he had wiped the water from his eyes the river was full of Malays. A long line of men, leaping, yelling, splashing, extended from bank to bank. In the deeper places they had to swim, but for the most part the stream was not more than breast-high.

By this time Alang Abdullah saw that the drive would not be a success. Had it been in proper condition, we should have been able by now to see the masses of fish that we were driving in front of us. We should have seen them racing through the clear water just before us, or else leaping in mad fright in the distance. The Jin of the Water has 
not been appeased, and the efforts of the men who are now driving, the work of the men who have toiled at the bamboo frame of the enclosure, and his own long strivings, have all been of no avail. And the meaning of it all is that the water is too deep and too much discoloured, that the fish have not therefore seen the drag-line sufficiently clearly, and that at the splashing of the nets and poles they have scattered almost as much up-stream as down.

But we who were at play shouted and splashed none the less cheerily. Shame on him who would make the little less. We worked our way steadily through the water to the head of the island; the drag-line was brought up to the gate of the enclosure (which was an opening some thirty yards wide), and then a number of men ran out with a bamboo "chick" frame and closed the entrance. Dug-outs were allowed into the enclosure by a shallow spot at the edge of the island. Every one rushed forward with his casting-net. Those who would not wait their time in the press of craft struggling through the narrow entrance ran down the island, and rushed waist deep into the water to get their haul of the fish. For although the drive was held to have failed, there was a very considerable quantity of fish in the enclosure. At first the nets took them three and four at a time, but these were mostly fish of not more than half-a-pound. Every one was furiously at work. We cast our nets, drew them in again, extricated our fish from its meshes, strung the catch on the rattan-line we carried at our waists; and before we had breathing-time we 
hurriedly disposed the nets on our shoulders, and dashed on to make another cast. Some magnificent fish were caught. The heaviest turned the scale at fifty pounds, but any fish over three pounds were rare. The man who caught the fifty-pounder fell on to it as soon as he saw it gleaming in his net, wrapped the folds of his net round it-fighting it spider-wise,-and then, hugging the encircling meshes to his breast, struggled to the island with his capture.

But soon the yield of fish diminished and the nets more and more often drew nothing, and at last we wandered up and down the enclosure drawing blank at every cast. Then we shook the water from our heads and faces, and said that it was over, and making for the welcome shade of the house-boats wondered to what extent the sun had taken toll of our skins. The men's "work" was now over, and we collected round the magun to see the "play" of the women begin. It will be remembered that the magun is the trap into which the fish could find a way from the enclosure but from which there was no escape. This had not yet been touched, and we could see that it held a very fair supply of fish. Malay chivalry leaves the magun to the womenfolk. Soon the Malay ladies, headed by our host's wife, all gay in wonderful silks, emerged from their boats and stepped into the water. The entrance to the trap was sufficiently opened to let them enter, and one by one they filed in. They were armed with things like short-handled shrimping-nets, and began to scoop about in the water. At once there was a tremendous leaping and splashing. Little fish jumped 
high into the air, spluttering and squattering and trying to work their way up the bamboo paling that hemmed them in; large fish, with their broad backs surging high out of the water, dashed vainly round the fatal enclosure.

The women scooped wildly in every direction, missing the fish and banging one another, and screaming wildly the while with expectation and annoyance, excitement and despair. Then, amid cheers from the throngs of men on the boats which surrounded the enclosure, one woman got a fine sevenpound fish in her net. "What am I to do with it?" she screamed, as she held the fish high above the water. The roar of contradictory instructions she received from the boats, and the vain efforts of her friends to assist her-efforts which she insisted to be meant to rob her of her prize-so confused her that, when another fish leapt up close beside she scooped at it wildly with her net, and of course released the fish she already had. At this she all but wept, and was about to retire to one side to compose her shattered nerves when luckily another fish was caught, and she immediately dashed forward to claim it as the one she had released.

Suddenly a splendid forty-pound fish launched itself out of the water, fair between the arms of a buxom dame. She gave a piercing yell of agony, but by some reflex action of the mind flung botn arms round it and clasped it to her breast. When she realised what she had done, she screamed again with pure fright; but the power failed her to open her arms and let it go. The heavy massive body of 
the fish writhed and struggled in her arms, its broad tail splashed the water on every side, and its great fleshy lips gasped into her face. But though she was half dead with fright, her terror only made her clutch the tighter. The other women rushed to help her, and the first, not knowing what she was doing, put her hand into the fish's mouth.

Luckily it was a toothless carp-like creature, but she was so surprised to find her hand there that she could only stand still and scream. Another lady seized the first round the waist, and with some frenzied idea of rendering assistance wrestled with her and nearly pulled her under water. It really looked as if the fish was more than a match for them all, when a man passed a rattan over the top of the palisade, and a cool-headed lady slipped it through the fish's gills, and it was eventually hauled out by the men outside.

A few of the ladies were however quite dexterous, and set to work in the most business-like way, strung each fish to their rattan-line as soon as they caught it, and without a moment's delay scooped about for another.

The fish that gave the most play were the halfpounders. One of them would leap high into the air, at least three women would scream, and two or three nets would be swept like butterfly-nets near the place where it had been, and would wildly clash in mid-air.

By this time the fish would have fallen back into the water, and a mélée of nets would wheel and dash madly into the water after it. It was the wildest 
sight imaginable, but eventually the last fish was caught and the whole drive was over.

The datoh gave the order for the bamboo "chicks" to be detached from their supports and to be put into boats for removal to his house, and then every one turned to estimating the weight of the catch. There were perhaps a dozen fish between ten and fifty pounds each, two or three dozen between three and ten pounds each, a considerable number of fish over a pound, and some hundreds of fish averaging half a pound.

But this was very little when the size of the river and the distance the drive had covered is considered, and it was obvious that the drive had passed over a very large percentage of the fish. In other words, the drag-line had had no terrors for the fish, and Alang Abdullah could not but feel that this meant that the fault was his.

He knew that he was not really to blame, and that the failure was entirely due to the postponement of the date he had selected. But it meant that he had done his best to keep back the rain, and yet the rain had fallen; that he had invoked the help of the Jins of the earth and of the water, and that they had not heard him; that he had used all his charms to make his drag-line a blinding, driving terror, and that a large proportion of the fish had disregarded it,-it meant, in short, in spite of all excuses that could be made, that he had failed.

The Englishmen were using their towels in the house-boats or lying down on their mattresses. They had enjoyed themselves thoroughly. It had been 
capital fun, and there had been enough fish for everybody. "A pity, though," said one of them, "that rain on Wednesday and Thursday."

But it was far otherwise that old Alang Abdullah thought of the rain on those two days. He thought of the successes and huge catches of bygone years, and thought of the fish that he might have caught on this occasion; he thought of Batara Kala and Hana Taskun, and the assistance vouchsafed by them in former drives and denied this year: and he turned away from the river with tired back and weary steps. He saw the gathered rain-clouds settling lower on the mountains, and deep in his heart he murmured, "It was not right! It was not right at all!" 


\section{THE WILD GOAT.}

"The unicorn, a very curious animal, is found in the vicinity of this lake." The lake is Atdza, and the author of this grave statement is the editor of the Chinese Official Itinerary of the road between Lhassa and Peking. M. Huc, the French missionary who more than two hundred and fifty years ago travelled from Peking to Lhassa and back, quotes the Itinerary and writes as follows :-

"The unicorn, which has long been regarded as a fabulous creatnre, really exists in Thibet. You find it frequently represented in sculptures and paintings of the Buddhic temples. Even in China you often see it in the landscapes that ornament the inns of the northern provinces. The inhabitants of Atdza spoke of it without attaching to it any greater importance than to the other species of antelope which abound in their mountains. We have not been fortunate enough to see the unicorn during our travels in Upper Asia."

M. Huc then gives the following extract from M. Klaproth's translation of the Itinerary of LonHoa-Tchon :-

"The unicorn of Thibet is called in the language of this country serou, in Mongol kere, and in Chinese ton-kio-cheou, which means the one-horned animal, or kio-touan, the straight 
horn. The Mongols sometimes confound the unicorn with the rhinoceros, called in Mantchou bodi-gourgou and in Sanscrit khadga, calling the latter also kere."

The Thibetan tradition of how a unicorn saved India from the Tartar hordes that overran the rest of Asia is not as widely known as it deserves in a land where a lion and a unicorn are the supporters of the Crown.

"When Jengis Khan had subdued Thibet in A.D. 1224, he set out to conquer India. As he was ascending Mount Djadanaring he perceived a wild beast approaching him. It was one of the species called serou, which has but one horn on the top of the head. This beast knelt thrice before the monarch, as if to show him respect. Every one being astonished at this event, the monarch exclaimed: 'The Empire of Hindustan is, they say, the birthplace of the majestic Buddhas and Buddhistavas, and also of the powerful Bogdas or princes of antiquity. What, then, can be the meaning of this dumb animal saluting me like a human being?'

"Having thus spoken, he returned to his country."

This "curious animal" is the one known to Indian sportsmen as the serow, and to zoologists as Nemerhedus or the "goat-antelope." It is not, of course, one-horned; and the only foundation for this belief that I can imagine is, firstly, its rarity, and secondly, perhaps, an artistic cult of drawing the animal in profile, and thus only showing one horn.

Nemerhedus has a range from Cashmere along the Himalayas to Thibet, from Thibet to the BurmoChinese frontier, and from Burmah down to the Malay Peninsula. It is also found in Sumatra.

Bubalinus, thibetanus, and sumatrensis are the names with which scientific men have thought fit 
to afflict the three species of an animal already burdened with the name of Nemerhedus and branded with the designation of "goat-antelope." Kambing Grun is the Malay name for this polysyllabic animal.

It is the only goat-like creature found in the Malay Peninsula, and I content myself with calling it a goat. Its distribution is as scanty as its range is wide, and its extremely shy and retiring habits, even in the parts of Asia where it is least scarce, make it one of the animals that fall most rarely to the rifle.

In the Malay Peninsula, Sir Frank Swettenham, the late High Commissioner for the Federated Malay States, is, so far as I know, the only European who has shot one. Very few white men have ever set eyes on a living specimen, or even come across the animal's tracks, and a considerable proportion of the European community is unaware of the animal's existence in the countrye. ${ }^{1}$

The limestone hills that are studded over the alluvial plain of Kinta, in the State of Perak, are the home of a considerable number of these goats. The sides of these hills are sheer precipices, and one gets a good idea of their general appearance when one learns that, in some period of geological pressure and upheaval, the limestone was forced up in a liquid state through the granite in the same way that oils in a painter's tube are squeezed out: the hills stand up above the plains in exactly the same way that the oil stands up above the mouth of the

1 Since this was written I have heard that a young goat has been captured in Selangor and presented by the Government to the Zoological Society. It may be seen in the Gardens at Regent's Park. 
tube. The trees and plants that cover them, wherever seed can find root, do not differ greatly from those of the forest that covers the surrounding plains, but so precipitous are the hills that in the landscape each of them looks as solitary as any crag that thrusts its head above the level of the waves in the wide sea. When one is close, the first general impression is that of an expanse of chill grey limestone, so sheer or overhanging that not even a fern can find root-hold on its bare side, and of a line of forest trees growing upon the summit in bold outline against the sky, and completely cut off by the precipice from the forest of the plains. A second glance, however, generally shows that the precipice is broken in places where the stone appears to have crumbled away, and that here the trees of the hilltop come down to meet the trees of the plain. The hills vary in size, some being little more than gigantic isolated boulders, whilst others are two thousand feet high and many miles in circumference. The slopes of the granite mountain-ranges that run down from the Burmo-Siamese frontier, and form the backbone of the peninsula, are infested by tigers and panthers, and it is probably from a fear of these animals that the goats have betaken themselves to the isolated and precipitous limestone hills, where they live in perfect safety from molestation. One of these island-like crags is called Gunong Kroh. I first came upon it by accident, and spent a night in a Malay house at its base, whilst in search of the tracks of a rhinoceros. The hill rose, like a wall, out of the level plain, within a few hundred yards of 
the house. Its highest point was some seven hundred feet above the plain. It was perhaps a mile long, and half a mile in width-a great roughly rectangular mass of limestone that lay upon the plain like a brick upon a smooth floor. There were places where the precipice was broken, and there, though the fall appeared to be only a few degrees less than perpendicular, trees and bushes grew so closely and so directly under one another that the tops of the lower trees seemed to brush against the trunks of the trees that sprang from the rocks above them.

Hussein, my host, described the hill as not difficult of ascent, its precipices being easily avoided, and said that it was the home of a number of wild goats. He told me that from the house, where we sat, he often heard them bleating, and that whenever men climbed the hill in search of the rare and valuable Kamuning wood they generally saw fresh tracks. It was seldom, however, that any one saw the animals.

"Shoot them?" he said, in answer to a question. "No, no one ever tries to shoot them. Why should a man climb a rock as high and as steep as that to shoot a goat when, with half the trouble, he could shoot a deer twice its size on the plain below?"

It was certainly an alluring prospect. There were some goats, perhaps even a considerable number, living upon this isolated rock, whose area was comparatively small and most strictly circumscribed. Even if they wanted to do so, the goats could not get away, and from the moment that one set foot on the hill one was within a mile of them. Viewed from below, the summit of the hill appeared to be 
fairly level, and it seemed to me that there was less undergrowth on it than there was on the plains, and that the trees were less closely packed together. I hoped, therefore, that when we reached the top we might have a fairly open view, and, if we moved quietly, perhaps have a chance view from one crag of a goat standing upon another crag.

I decided to return at the earliest opportunity to climb Gunong Kroh, and went on the next morning after the rhinoceros, which I was lucky enough to shoot. A few weeks later W. and I slept in Hussein's house, and early next morning, accompanied by our host, began the ascent of Gunong Kroh. A nearly perpendicular climb of a few hundred feet, which was much easier than it looked, brought us to a ledge, and then we saw that the hill was not the solid mass of rock that I had imagined it to be, but really basin-shaped, and that a considerable area of ground on the same level as the plain of the Kinta valley was enclosed within its limestone walls. Hussein, who had often climbed the hill before in search of forest produce, was of course aware of this formation, but had omitted to tell us. We clambered down to explore the extent of this secret hollow, and found goat tracks all over it. In the side of the hill there was a cave which seemed to be used as a place of shelter, for inside it and round its mouth the ground was trampled deep with hoof-prints.

After a careful examination of the ground we came to the conclusion that it was only at night that the goats came down to the level ground in the basin. 
The highest points of the hill were at its western and eastern extremities, and the sides of the basin on the north and south dipped considerably below the level of the two highest peaks. To reach our present position in the hollow we had climbed over the rim of the basin at one of its lowest points, and decided to climb up the opposite side of the basin, and to make our way round its rim to the western highermost point, and thence back, also along the rim, to the place where we had made the ascent. The lower part of the climb up from the cave was not difficult, and we were able to carry our rifles in one hand. But after the first hundred feet or so we found that both hands were required for climbing, and had to improvise rifle-slings out of the stems of forest creepers. Wherever the face of the limestone was not absolutely perpendicular-wherever, that is to say, seed could lodge or root could cling-there grew some plant or bush or tree. They seemed in some way to receive a sustenance from the bare rock, for there was no soil. Great snaky roots clambered for yards upon yards over the barren limestone, dropping a little bunch of rootlets into any crevice that offered a hope of moisture or of support. Often the trees grew out of the rock horizontally, and the trunks did not turn skywards until a few feet from their base. But, so far from affording the assistance in climbing that one would have expected, both tree trunks and roots always seemed to block the way. The surface of the limestone had, through long subjection to alternate heat and rain, become rotten, and the roots insinuating themselves into every crack and interstice 
had loosened great masses of rock. Not only were there places where a rock that jutted forth to offer a tempting foothold was really ready to drop the moment that the least weight was laid upon it, but often we found ourselves underneath a boulder that had been broken off, and that hung, supported by a cat's-cradle of creepers, ready to fall at the slightest oscillation.

We reached the rim of the basin, with nothing worse than cut hands. The amount of vegetation on the top of the hill was surprising, and leaf-mould, which was practically the only soil, had accumulated to a considerable depth where the rock was level enough to prevent it being washed away. Some of the trees were of considerable girth, and rattans, with their thorny covering, writhed over the rocks and blocked the path in every direction. Between every tree hung festoons of creepers. There was a profusion of begonias, with coarse, quaintly shaped leaves and little bunches of white flowers; and hanging ferns of every variety grew wherever there was moisture, and dwarf spiky palms wherever there was shade.

The luxuriance of the undergrowth completely upset our calculations, for, as I have said, we expected to have a moderately open view among the larger trees of the hilltop. We found, on the other hand, a vegetation no less dense than that of the plain below growing out of gigantic masses of rugged rock. At places the ridge narrowed to a ledge not more than a few feet wide, and then a little distance farther on it widened to an irregular broken surface of rock that was perhaps a hundred yards across. 
Sometimes we had a sheer fall of some hundreds of feet below us, on one side or the other, towards the open forest plains or towards the central basin; and sometimes we could see the way of a more or less practicable descent through tumbled masses of boulders and forest growth.

At one spot I had a narrow escape. We had left the top of the ridge, and were making our way along the side, when we came to a sheer precipice. It rose above us in an almost straight unbroken line, and its base was hidden from view underneath us. Where we were it was not, however, more than a few feet wide, and irregularities afforded hand and foot hold.

W., clinging like a star-fish, worked his way across it in safety, and I followed. I had to reach out with one leg, as far as I could, to the foothold of a crevice, and, thus supported, to lean out until I could seize hold of a bush that grew out of the sheer face of the precipice. Holding on to this, I had to stretch forward again to get foothold on a little knob of rock that jutted out a few inches, and thence reach a sapling which grew out of more practicable ground. Holding on to the bush, with two or three hundred feet of sheer fall below me, I was putting my foot on the projecting rock when it gently gave way under my weight. The little knob and part of the rock behind detached itself from the cliff and dropped in silence out of sight, and it was some seconds before we heard the crash in the depths below. All my weight was thrown on the bush, which stood the strain for a moment; but as I turned to make my way back to 
my starting-point, my support began to gave way. The roots came slowly out of the bare rock, first brown, then browny-white, then white. I was only a few feet from W. on the one side and from Hussein on the other, but it was almost impossible to move towards either of them. Luckily W., holding a treeroot with one hand, was able to reach over to seize my outstretched hand and pull me into safety. It was only just in time; and we left the poor little bush, with all but its last white roots torn out, hanging head downwards over the precipice. Hussein had to go back and make a détour to reach us.

We were making our way over and round, up and down, gigantic masses of boulders covered with vegetation, when we heard a tremendous crashing through the trees not many yards in front of us, and then the sound of an animal going sheer down the rock to our left. Thud-thud-thud. It' sounded like the fall of a leaping rock, and we could hardly believe that a living animal could be charging down such a breakneck spot at so headlong a pace. In a few seconds we heard it wildly galloping through the undergowth of the central basin below us. Then the sounds died away, and that was all. We saw nothing, of course. We found the place where the goat had been sleeping, and picked up some long coarse hairs. We kept on our way, and soon the rock began to rise towards the western peak. The central basin, which we had had on our left-hand side, now came to an end, and we turned our backs upon it to climb the peak. It was a great dome-shaped mass of rock covering a great many acres, and, like the rest of the hill, was 
broken, rugged, and densely covered with forest growth. We found several marks of goats on it, and on our way down put up, and did not see, another goat, which, like the first one, dashed away in the direction of the central basin.

Our only other adventure was W.'s narrow escape from falling down a natural pit. All the limestone hills are riddled with caves and pits, which are the immemorial home of colonies of bats, and of curious white sightless snakes that feed upon the bats. A crack or crevise in the rock, covered with a fibrous matting of root, leaves, and moss, often connects with great caverns that extend into the centre of the hill; and one has therefore to be careful where one treads, for a man who disappears down one of these pits has little hope of being rescued. W. stepped straight into one trap, and plunged in until his outstretched elbows saved him. We quickly extricated him, but he was lucky to get off with nothing worse than a shaking.

By the time that we had made our way back to the point where we had first ascended the hill, we saw that the combination of dense vegetation and broken precipitous rock prevented any chance of our coming upon the goats by surprise. We decided, therefore, to try to drive them, and returned to Hussein's house to make the necessary arrangements for the following week.

In the course of the conversation Hussein gave us an interesting piece of information regarding the cave in the secret hollow of the hill. I had noticed that he seemed rather afraid of the cave : it was, he said, 
because he was afraid that he did not tell us at the time that the cave was supposed to be the home of Orang Bunyi, or Voice Folk. These are invisible supernatural people who inhabit the forest, and who may sometimes be heard but never seen. Stories are told of Malays who have wandered in the forest depths until they reached the outskirts of villages inhabited by the Voice Folk, and heard the cooing of the tame pigeons round their dwellings. The Malays say they occasionally hear the Voice Folk calling to each other in the forest, and that their voice is exactly like that of human people. He who hears them generally finds that the voice is calling him by name. "Awang! Oh, Awang!" it will cry, if Awang be his name; "come here, some one is calling you. Come quickly." When one hears the voice, the only thing to do is to seek safety in flight ; but sometimes a man, either mistaking the tones for those of some fellowmortal, or fascinated into wilfully seeking his doom, answers the call. If he does so, his fate is sealed. He cannot turn back an irresistible force compels him to follow the volce farther and farther into the forest depths, where finally the Voice Folk make themselves visible to him. He then becomes one of them, and, like them, invisible to mankind. Once, the Malays relate, a man returned to his village after having married a Voice Woman. But he, they say, is the only man who has ever returned, and he died nearly twenty years ago.

Upon the day appointed for the drive, W., my brother Eric, and I met Hussein and some dozen Malays at the foot of Gunong Kroh. Our plan was 
that these men should take up stations at regular intervals round the western end of the hill, and that each man should then climb to make his way as best he could towards the highest western peak. We thought that any goats that there might be on the western end of the hill would naturally, upon the first alarm, make their way to the eastern end, and that to do this they would either pass through the central basin or along the rim on either side of it. We told the men not to shout or yell; they were merely to rap the trees and to make such reasonable amount of noise as a wood-cutter or rattancollector would make in pursuing his vocation. As soon as the Malays had moved off to take up their stations round the hill we drew lots for places. The central basin fell to my brother, the northern rim to W., and the southern rim to myself; and we betook ourselves to our positions.

I made my way along my side of the hill until I reached the place where, at the end of the central basin, the southern rim began to rise up into the western peak, which was the point for which the beaters were to make. I found a goat track, and selected a hiding-place from which I could watch it. In front of me the limestone rose abruptly in great jagged crags and broken boulders, through and among which tree-stems fought their way and treeroots crept. To my right a steep descent led down through tumbled masses of stone and tangled vegetation towards the central basin, and on my left was some broken rock ending in sheer precipice. Near the base of the precipice was Hussein's house. The 
sensation of having another scene at one's feet was extraordinary. It was quite different from the feeling one has when from a mountain top one sees a valley spread out beneath one; for there, though one says that it is as though the plain were at one's feet, yet the sense of atmosphere and of perspective dispel the illusion even as one gives utterance to it. But in this case the expression was literally true: underneath me I could see Hussein's wife winnowing rice at her door-step amid a number of hens that clucked and cackled at her feet. In the little stream beside the house her children were shouting and splashing. All were very small and far away, though in a horizontal distance they were not very much farther away than one can throw a ball; and, looking down upon them from the height of the precipitous limestone hill, I felt as though I looked down upon them from such land as grew on Jack's Beanstalk.

I had a long time to wait before the drive would begin, and screening myself behind a tree I made myself as comfortable as possible. By good fortune a pair of tiny long-billed birds were making a nest in a branch within a few yards of my head, and they would have kept me interested for many hours longer than I had to wait. The joy of these beautiful little creatures in their building was so intense that no one could fail to be affected by it. Their nest was a hanging one of delicate woven fibre, and it looked as if they had robbed the spiders' webs to make it. As each of the pair flew up with its tiny contribution, it called to its mate to see what 
a beautiful thing it was bringing; and as each flew away it called again as if to say that it would find something yet better next time.

When I had been in my place a little over an hour, a magnificent python, some twenty feet long, moved past me within its own length's distance of me. It had probably been disturbed by a beater when basking on the rocks; but it was in no way alarmed, for it moved slowly and deliberately. A truly splendid creature: it had recently shed its skin, and its new coat shone and glowed in the bright sunshine, and all the shades of purple and yellow in the mottled reticulated pattern of its colouring alternately reflected and retained the light. Its broad massive head and round bright eyes, its royal length and girth, all told of a dignity and majesty even among the beasts that creep upon their belly.

A few minutes later, and then came a tremendous crash among the trees on the heights in front of and above me. Instinctively my hands gripped the rifle tight, and for a second or two there was a wild pit-pat at my heart. Most people's hearts go wrong for a second or two in a drive, I think, when they first hear the game afoot. It is perhaps the sudden change from passive inaction to active expectation; and that is the reason, perhaps, why one does not have the same sensation in tracking big game, for there the exercise keeps one's pulse steady, and it is generally only a matter of the change of the degree of expectation.

Crash! again, and then a heavy thud on a rock; 
silence for a moment, and then another thud, followed by a crash. The noise was coming straight towards me, and I shook my elbows free of the coat-sleeves. Then came a crash within twenty yards of me, and then-oh, horror and disgust! - a big, black, longtailed monkey hurled itself into sight. It landed with a tremendous thud on a bare rock within a few yards of me, and then nearly collapsed with fright on finding my solemn eyes returning its stare. It flung itself on to the nearest rock, and thence, with a wild leap through space, swung into a tree. The moment that it caught its breath it uttered a series of piercing, hysterical whoops, and, screaming and crashing through the trees, it passed out of earshot.

There was some time to wait after this, and then on the heights in front of me I heard a sound as if some one had dropped a pebble. Tpp! that was all. A few seconds later there was the same sound againtpp! After a few moments again the same soundnothing more; each time the sound seemed to come closer. I could not imagine what the cause might be, but had a vague idea that it might be a small monkey. Then I saw something on the higher elevation to my front left drop a distance of some six or eight feet and land lightly on a rock. Tpp! It was too far for me to see what it was, and the bushes and tree-trunks hid it almost entirely. Again it leapt down a sheer fall of rock and landed among some boulders about thirty yards away from me. And then I saw that it was a goat. It was only a young one-not more than a third grown, I imagine. From the glimpse 
I had of it, it seemed to be covered almost to its heels with tremendously shaggy brown hair. That and its immature appearance was all that I had time to take in. It saw me as soon as I saw it, and though I instinctively raised my rifle before I realised that it was too small for me to shoot, it gave a wild bound and disappeared behind a rock before my rifle had reached my shoulder. A second later I heard it dashing headlong down the precipitous descent to the central basin, where my brother was stationed.

It was worth all the toil and trouble that we had gone through to catch merely the one glimpse that I had had of the animal. It would have been worth many days' journeys to have been able to see, and not merely imagine from the hearing, the dainty way in which the animal leapt down the sheer limestone from crag to crag, and to have seen and not merely heard the mad flight through the blind undergrowth and murderous limestone pitfalls. That was the only glimpse that I have ever had of a Kambing grun, but I would not have missed it for a good deal. I am glad it was a young animal, for had it been some patriarch of the herd my recollection of the encounter might have been embittered by my inability to get a shot, whereas now I can hug to myself the thought that even if I could I would not have fired.

Not long after some of the beaters came up, and the drive, so far as my side of the hill was concerned, was over. I sent the men down the hill to the central basin, in which my brother was stationed, for as this was the direction the kid had taken I thought that 
other goats had probably collected there, and I made my own way to the point where we had ascended the hill. After a considerable interval my brother and W. came up, and the beaters straggled in close behind them. Neither of the other guns had seen or heard a goat, and both heartily condemned the proceedings as a failure. One of the beaters, a brother of Hussein, had, however, come upon a goat which had refused to give way to him. His story, which is quite worthy of belief, was that he was making his way up the steep side of the hill when this goat stood in his path and refused to let him come any farther. It stood still in one place facing him, shaking its head at him as if about to charge, and stamping the ground with its hoofs. Discretion was the Malay's only policy, and he wisely retreated and sought another path.

The beaters all spoke to fresh goat tracks on all sides, and their explanation of the ill-success of the drive was that paths made by the goats led in every direction. The goats on the western extremity, where our drive had been, could make their way to the eastern peak without passing near any of the three stations we had taken up; they could skirt along the hill above or below the precipices on the outer side of it, or they could contour the inner side of the central basin. There was no means of driving them in any particular direction, and that a goat should pass any given point was purely a matter of chance.

After a thorough discussion, during which various plans and theories were suggested, we finished our cigarettes and made our way back down the hill to Hussein's house. 
On several subsequent occasions we tried our luck on Gunong Kroh, but never did any of us see another goat.

It is now some years since I was stationed in Kinta, and I am prepared to tell the world the locality of Gunong Kroh. On those limestone heights, isolated in a little world of their own, far apart from the animals and life of the wild plain below, the goats are still to be found. The little goat I saw is now, if it is still alive, a patriarch of the herd, but in my thoughts it always remains the kid that once I saw. Mine are the only eyes that have ever seen it-for no one, except an occasional wood-cutter, has climbed the hill since our last drive, and, for all that the rest of the world knows, it and its brethren may be some of Monsieur Huc's unicorns.

To seek it, go out from Ipoh seven miles on the Sungei Raia Road, and you will see the sheer sides and timbered crest of Gunong Kroh standing up in the forest on your right-hand side. The animals are there, and when you have once scaled the hill you are within a mile of them: all that remains to be done is to decrease that distance. And when you go there, may the best of luck attend you ! 


\section{THE BLAT ELEPHANT.}

Aнman, my head boatman, came into the verandah by the front stairs, and I knew that he had important news. The old man had his own way of doing everything, and whenever he came to see me about the Government boats, or any other matter of pure business, he came in through the servants' entrance. If he came on an errand connected with shooting or fishing, he felt that the relationship between us justified him in using a side entrance to the bungalow. But when he came with khabar of big game, he always presented himself at the front door. When I looked up from my official correspondence I saw him in the doorway. A smile beamed upon his face, and with an air of appreciation he scratched his left shin-bone with the gaunt big-toe of his right foot. He stood in silence, waiting till my expectancy should reach that happy moment when it is fully ripe, and is as yet untouched by the canker of irritation. His smile grew and broadened until he showed every ragged tooth or empty socket in his old head.

"The Blat Elephant is feeding near Kuala Sol." He paused to let me take in the news to its full extent, and then continued: "The tide will be 
running up this afternoon. If we start at five o'clock in the big house-boat we shall reach Kuala Sol by eight o'clock, and can start tracking the first thing tomorrow morning. May I give orders accordingly?" A few questions and a little consideration showed that Ahman had thought the whole matter out, and that nothing was left for me to do but to acquiesce.

He went away to make the necessary arrangements, and a few minutes later Sleman, another of my boatmen, came up to put my 10-bore rifle in its case. He was the youngest of my crew, and always accompanied Ahman and myself upon our shooting expeditions, his special duty being to carry the sandwich-case and water-bottle. An exceedingly nice youngster of about nineteen, he came from one of the northern unprotected states of the Malay Peninsula, and being new to the ways of the white men was, when he first joined my service, somewhat shy and awkward. He was very keen, however, to learn all that he could about every form of sport, and under Ahman's tuition was going through a regular course to "obtain courage." Abstinence from certain kinds of food, ghee in particular, seemed to be the most important condition, but there were many charms and invocations to jins and legendary heroes to be learnt, and there were some rather extraordinary observances to be kept. Both men looked upon the course as a very serious matter.

Punctually at five o'clock everything was ready; the house-boat pushed off from the landing-stage at the bottom of my garden, and the incoming tide bore us smoothly up the Kuantan river. Ahman 
kept the boat in mid-stream, and the four boatmen, who sat in the bows, gently and rhythmically rapping the boat's side with their paddles at each stroke, had little more to do than to maintain sufficient steering way.

Both banks of the broad river were covered with a dense forest of mangroves, and trees with dark, glossy, fleshy leaves and quaint-shaped fruit pushed one another actually into the river. A couple of miles above my house we entered a tributary of the Kuantan, the Blat, which gave its name to the elephant we were seeking.

At the next bend of the river Ahman pointed to the bank, and asked me if I remembered it. I remembered it well. Some months before, when the Blat Elephant had last made one of its periodical visits, Ahman and I had tracked it into this mangrove forest. It was not easy to forget the horrible, slimy, stinking mud, punched by the elephant's feet into great oozy holes, between which we had to pick our way; the dense entanglement of branches and leaves all thickly besmeared with heavy slavers of the same mud wiped off the elephant's body; and the almost unimaginable myriads of the mosquitoes. Every separate nipahpalm leaf, every single mangrove branch, was the resting-place, not of dozens, but literally, I believe, of hundreds of the most venomous little brutes. From each leaf, each branch, there darted forth at our touch a crowd of mosquitoes that can only be compared to a swarm of bees at an overturned hive. Our faces, necks, and hands were black with mosquitoes. They bit with extraordinary viciousness, and the agony, as 
of an incessant beating with stinging nettles, was almost intolerable. The myriads that hung in clouds round our heads made it difficult to see, and almost impossible to hear. And it was in great part due to the mosquitoes that when we got up to the elephant, which had by wallowing protected itself with a thick coating of mud, we were unable to get close enough for a shot. I managed to see some branches moving, but that was all. At last, when the elephant either scented or heard us and made off, we were so tortured as to be glad of any excuse to return to our boat.

The banks that hid this most unpleasant spot were sliding quickly by us, and soon after sunset the houseboat entered the Sol, a tributary of the Blat. A short way up this river the mangroves were replaced by ordinary forest, and before long a bend in the river disclosed the cheerful light of a small house in an isolated clearing on the bank. We tied up at the landing-stage, and in answer to our hail the owner of the house, a man named Brahim, came down to the boat.

He was able to give us all the information that we required. The great solitary elephant, which for years out of memory had appeared at intervals in the valley of the Blat, played no small part in his life and in that of the agricultural population of the district. On every visit it did an enormous amount of damage in the plantations and gardens, destroying coco-nut and plantain trees and knocking down houses, and Brahim and the Malays of the district looked upon it as one of the ills to which their life was subject. They regarded it as they would regard a flood, a harvest failure, or an 
outbreak of smallpox. All of these things were alike in this respect, that of none of them could the occurrence be prevented by any human power, and that forethought was therefore merely an unnecessary and unintelligent anticipation of a possible future evil. A calm acceptance of the fate that placed him within the area influenced by the elephant thus gave a curiously impersonal tone to the manner in which Brahim thought and spoke of it. He told us that the elephant had fed the night before in an abandoned clearing about a mile farther up the river, and that he expected it to invade his plantation this night or the next, but talked in a voice so unconcerned that one could hardly realise that he was speaking of the imminent depredation of what was practically the only property that he had in the world. I was struck, too, by the way in which he appeared to regard the elephant as a tool in the hand of some maleficent demon rather than as a voluntary harm-doer, or as a manifestation of evil rather than as the evil itself. Against the elephant itself, therefore, he appeared to have no ill-feeling. He seemed not to have the inclination, which would have been natural to many people, to curse it. $\mathrm{He}$ did not even call it a beast, or a brute. He only spoke of "it." This did not, of course, in any way prevent him from having a hearty desire to see it killed.

He told us that he had vowed to slay a goat when the elephant was killed, and mentioned the names of some of the richer Malays in the Blat district, each of whom had vowed to slaughter a buffalo upon the same auspicious occasion. Almost every man in the water- 
shed of the Blat and Sol appeared to have made some vow to be fulfilled upon "its" death.

While we were thus talking, voices hailed us out of the darkness that lay upon the river. A couple of Malays passing down stream in a dug-out, recognising my house-boat and guessing our errand, called out to let us know that they had just heard the elephant feeding on the opposite bank of the river, about half a mile up-stream. Brahim told us that the ford by which the elephant generally crossed the river was at this place, and we decided that, if we waited there in a boat, we might possibly surprise the animal at the shallows. Ahman, Sleman, and I therefore took a dug-out and started without further delay.

Before we had gone far, we heard the elephant feeding, about a quarter of a mile inland from the river bank. It is not easy to say how impressive the sound was in the stillness of the night as it came from the darkness of the forest, which stood up walllike above the river bank. There was the peaceful sound of the elephant's slow, contented feeding, mixed with occasional sounds of the flapping of an ear, rumbling and squelching noises in its stomach, and an intermittent thwacking of its tail upon its sides. Now we could hear a bough being snapped off, and now a bunch of grass being torn up by the roots. It seemed a shame to think of killing an animal so huge and so unseemingly inoffensive; and it was necessary to harden my heart with the memory of the mischief that it wrought. The wind was blowing from it to us, and we waited in silence beside the ford. It fed slowly towards us until only a 
couple of hundred yards separated us, and then stopped a long time under a tree to pull down a hanging creeper. The whole operation was marvellously distinct. We could hear the branches shake, and bend, and creak, as the animal tugged at the creeper's stem, and then the creeper's hold would give a little,-its tendrils would release some part of their clutch of the leaves and twigs of the tree, and the tearing and rending of the severance was followed by the elephant's slow munching of the lower part of the creeper until it had eaten up as far as it could reach and began again to pull down more. While this was going on, a couple of bears passed by "woofing" to one another as they shambled hurriedly through the forest in search of food. Soon afterwards the elephant stopped feeding, and moved away. I do not know whether a treacherous slant of air gave it our wind, whether the smell of the bears offended it, or whether it wished to seek a fresh pasture. At all events, we heard it no more, and after a while returned through the darkness to the house-boat.

Before sunrise the next morning we were back at the ford, and picked up the elephant's tracks at the place where we had heard it feeding the night before. There was nothing to show that it had been alarmed in any way: it had walked slowly away, feeding as it went. I had often seen the Blat Elephant's tracks before, but the fresh deep prints with the clean cut impress of the toes always struck me with an ever new feeling of the hugeness of the animal. We followed the tracks through fairly open forest, passing 
a place where it had slept, and then heard it feeding some two hundred yards away. The wind was in our favour, and I moved towards it as noiselessly as I could. I got within fifty yards, and could hear with the most tantalising plainness the flapping of its great ears against its neck, and the swishing of a branch that it held in its trunk to fan its sides. I could also hear the gurgling noises attendant on digestion. But I could see nothing. I crept stealthily closer, and saw a branch move. It swung gently to and fro as the elephant slowly rubbed itself against a tree. Then there was a sudden silence. This continued for a few seconds, and then I heard the elephant move rapidly away. To have hastened after it in the hope of catching it up would have been worse than useless. The only thing to do was to keep quiet for a few minutes until the elephant had left the scene of its alarm. We were surprised to find it so wide-awake and suspicious, and Ahman expressed the feelings of us all by saying that even a deer would not have shown such a lamentable excess of caution.

We followed up the tracks for many miles after this without seeing or hearing anything more of the elephant. When the afternoon was wearing on, we decided to give up for the day, and cut a line through the forest to return to the house-boat. It was nearly dark when we got back. As we were of opinion that the elephant was making for a point some few miles higher up the Blat river, I had the house-boat poled up there in the hope of finding fresh tracks the next day.

After dinner, while I lay upon my mattress in the 
house-boat, I heard old Ahman telling Sleman and the other boatmen stories that deserve to be recorded. This is one way to kill a rhinoceros.

Take a piece of hard wood (lengapus for choice), eight inches long and two inches thick, and sharpen the two ends to as fine a point as possible. Armed with this, follow the rhinoceros. When you come upon it, shout and boldly advance. The rhinoceros will thereupon rush at you. As is the custom of the animal, it will charge at you with its eyes shut and its mouth open. When it approaches, step aside, and taking the stick between your thumb and first finger-so-hold it out perpendicularly, and put it in the animal's open mouth. The rhinoceros will snap upon it, and the pointed ends entering the upper and lower jaws will close the mouth for ever. As it cannot eat it will starve, and all that you have to do is to follow it until it drops down dead.

The system employed by a friend of Ahman's for killing elephants also has much to recommend it. Elephants, it is well known, move on from one feeding-ground to another in a regular rotation and at fixed times. Ahman's friend could go to any place where elephants had been feeding and tell from the appearance of the trampled ground and the condition of the new grass and leafage how long it would be before the herd would return. When the elephants were due at any place he would arm himself with a long iron spike and a mallet, and climb up into a convenient tree. When the elephants came, -of course they came,-he waited until a tusker 
passed under the tree, and then let himself drop upon its back. He then scrambled his way to its neck, seated himself firmly there, and proceeded to hammer the spike as quickly as he could into the animal's brain. The elephant, of course, would not stand still while this was being done: it would crash away through the forest, but no branches could sweep Ahman's friend from its back. Where it could go, he could pass, and the elephant seldom went far before the spike pierced its brain, when, of course, it fell down dead.

Ahman was beginning another story descriptive of a method of killing elephants by a dynamite fuse on the end of a bamboo pole, when one of the boatmen, a mannerless cub from Kemaman, interrupted the tale by bluntly calling him a liar. Ahman was so hurt that he refused to speak another word. The light was soon put out, and the men pulling their cotton cloths around them disposed themselves for the night. I lay awake some time after they were all asleep. It was an intensely dark, still night; there was the whisper of the river at the bows where the boat broke its flow, and its caress at the side where it ran softly by. Everything was black, but not undistinguishable: I could see the blackgreen line of the great forest standing on the river bank; the river was one flat dead gleam of bottleblack, and over all was the hollow black sky. At intervals some night bird would utter a single mournful note.

We were all awake at early dawn, and when the sun was showing over the distant mountains Ahman, 
Sleman, and I set out to look for fresh tracks. We took a straight line through the forest for some miles in the direction which we imagined the elephant to have taken, and then made a wide sweep round towards the place we had been in the day before. We found nothing, however, and late in the afternoon returned to the house-boat disappointed and weary.

As we appeared upon the bank, we were greeted by a shout from the other boatmen, almost in chorus.

" 'It' fed in Brahim's garden last night."

Poor Brahim! There was something very pathetic in his fate. While we had been running through the forest, like questing hounds, in search of the elephant, he had sat quietly in his house to await its coming.

We unmoored the house-boat, and paddled downstream to Brahim's house. He was perfectly calm and impersonal, the fact that the damage was in the past instead of being in the future making no difference to him. He took us round his garden as the sun was setting, and, amidst the wreckage of the leaves and branches and the great pit-holes where the enormous feet had sunk into the soil, showed us where some twenty fruit-trees had been destroyed.

While we were discussing the probability of the elephant's return to the plantation during the night, a couple of rattan-cutters passed by on their way home from their day's work, and informed us that it had in the last hour or two crossed to the other side of the river some three miles lower down. 
There was little chance of another visit from it, therefore, and we turned in to sleep at an early hour.

At daybreak next morning Ahman, Sleman, and I set off down-stream in a small dug-out. We found the place where the elephant had crossed the river, and landed. The tracks showed that it had fed close to the river bank most of the night: then they led inland, and we followed them for some hours. We were now some miles down-stream of the country in which we had been tracking for the last two days, and were not far from the mangrove belt and the tidal area. The forest was no less heavily timbered than that farther up-stream, and the undergrowth was even more dense and more thickly encumbered with rattans and thorny creepers. The greater part of our way lay through swamp and morass, in which patches of higher ground were interspersed.

At about ten o'clock Ahman kicked a piece of the elephant's dung in half, and felt in its centre with his bare toes to discover some remnant of heat. It was quite cold. "We must hurry," he said; "the elephant is a long way in front of us."

The tracks followed a well-defined animal path through the forest, and it was only necessary to keep to this path and have a watchful eye for any place at which the elephant might have left it. We hurried along, Ahman close behind me and Sleman at his heels. And a few hundred paces farther on, at a place where the path made a sudden bend round the trunk of an old dead tree, I saw lying 
down on the path, only a few yards away, the Blat Elephant.

It was sound asleep. Flat on its side, it had its head on the ground, and all four feet stretched out. It lay across the path with its back to me, and rattans and forest-creepers so hemmed it in that its head was hidden on one side and its hind-quarters on the other by undergrowth and tangled foliage of every description. The two men stood still behind me, while I crept forward a few paces and knelt down under the dead tree to take a steady aim. The animal was not more than fifteen yards away, but the gaunt ridge of its backbone and the nape of its neck were all that I could see. To right and left were great tangled masses of rattans, whose stems were sheathed in great thorny coverings, and whose every delicate tendril carried stems of clinging hooks ; and I dared not attempt to make a détour to get a shot at the elephant's forehead. I knew by experience how alert it was, and that I should not be able to move more than a few yards before it would hear me. I took a steady aim, therefore, at the last vertebra at the nape of its neck, expecting the bullet to smash its backbone and perhaps to rake into its brain. I fired, and all was still.

Peering under the smoke of my 10-bore, I saw the animal lying motionless. I waited a few seconds, and then looked round towards the two Malays. The week before, shooting in the Kuantan valley, I had killed a fine tusker elephant with a single bullet in the brain. This made two consecutive elephants with two consecutive bullets; and the second of them was 
the famous Blat Elephant. Trying to conceal my emotion, I beckoned to the men to come up, saying that the animal was dead. But "dead" had barely crossed my lips when there was a rending of the rattans, and before I could move the elephant was charging straight at me.

A second before, it had been lying on the ground with all four feet stretched out, and with, I believed, a bullet in its brain. An elephant cannot spring to his feet, and a tame animal generally takes some time to rise. The suddenness of this charge may therefore appear exaggerated: I can only say that I was standing within a few yards of the animal, and was not aware of any interval of time between its lying silent on the ground and its charging me. I saw the green rattans tearing asunder to right and to left, away from an enormous brown head-a trunk tightly coiled up and a pair of huge gleaming tusks. It was all high up in the air, and right above me-imminent as a wave that curls before it breaks. With my second barrel I fired into the centre of the enormous brown chest, the head being so high and so close that it was covered by the tightly coiled trunk, and then with an empty rifle I turned and ran down the track up which we had come. The elephant was only a few yards behind me, and I ran for life.

Before I had gone more than fifteen or twenty yards I tripped and fell heavily to the ground, my rifle being flung from my hand. Death seemed certain, and I could only hope that it would be painless. But, to my intense surprise, the elephant had not followed me. Looking over my shoulder, I saw 
it standing under the great dead tree, from underneath which I had fired both shots. I picked myself up and, not daring to wait to get my rifle which had been thrown into a thicket by my fall, raced down the path again and hid behind the first convenient tree. From this point of comparative safety I saw the elephant still standing under the dead tree. It was fumbling dizzily with its trunk in the heavy smoke of the black powder-fumbling to find me. The blood was pouring from the wound in its chest in great throbbing jets, and the bright green undergrowth was drenched with heavy red.

After a few seconds the great brute began to scream with rage and pain. How it screamed! As the numbness caused by the shock of the first bullet wore off, the pain of the wound and of the second bullet in its chest drove it to frenzied madness. It trampled over the ground which was already besmeared with its blood, and, with trunk outstretched and ears thrust forward, turned in every direction to seek its assailant. My empty rifle lay between us, and I could not think of attempting to move towards it. Neither dared I move farther away, for any motion on my part might attract its attention. Ahman and Sleman were both unarmed, for in those days I did not own a second rifle, and we all cowered behind our respective trees. Any one of us, of course, could have killed it had he been armed. And each one of us knew that at any minute he might be detected, and then inevitably be killed.

After a time, - it may have been only a few minutes, but it seemed like hours,-weakened by the loss of 
blood and convinced perhaps of the futility of its search, it moved slowly away. We came out from our hiding-places, and all were very shaky. I picked up my rifle and reloaded it, and then, after a few minutes' rest to settle our nerves, we set off again after the elephant. When we had gone about a quarter of a mile, Ahman, who followed in my tracks, step for step, tapped my shoulder.

"He is going to plug up his wound," he whispered, pointing to a dwarf palm from which some leaves had been torn. I stared at him without at first taking in his meaning, and then, thinking of his quaint stories, continued my silent tracking without making a reply. A few yards farther on Ahman pointed to a place where the elephant had picked up in its trunk a small quantity of soft oozy mud. "Aih! Is he not clever? There is the poultice." This time I stopped, and asked him what he meant. He replied that the elephant would insert a plug of the palm-leaves into the opening of the wound in its chest, and then cover the whole wound over with mud. It seemed almost incredible, but the time was not one for arguing about animal intelligence, and I followed the tracks again. And, sure enough, before we had gone much farther the blood that had so plenteously besmeared our path suddenly dwindled to a scanty sprinkle, and shortly afterwards to a few thin drops at intervals.

After another hour or so the tracks grew firmer, showing that the animal was staggering less and was recovering its strength. Later we came to a fallen tree some five feet in diameter that lay across a bit 
of swamp, and saw that the elephant, instead of wading through the swamp, had used the tree as a bridge to walk upon. This was most disheartening, and Ahman, cursing the elephant heartily for a tightrope dancer, urged me to hasten, saying that the animal was now in all probability going faster than we were. We therefore pushed on as fast as possible, trusting that any sound we might make would be unheard by the elephant in the noise of its own movements.

But we had soon to redouble our caution, for in one place the elephant had taken a sudden loop and turned round to watch its own tracks. This is not unusual with wounded animals whose strength and size makes them dangerous, such as rhinoceroses, sladang, and elephants; and when any animal adopts these tactics, its pursuers are running a very great risk. They see the tracks lying before them, and naturally only look for danger in front. But what has happened is that the animal has all but completed a great letter P. It just stops short of completing the lower part of the loop of the capital letter, and, standing back a few yards from the main line of the letter, watches its pursuers advance. It allows them to pass, and then without warning it charges them from behind.

On this occasion, however, luckily for us, the elephant had for some reason moved on again before we reached the spot which it had been watching.

At about two o'clock in the afternoon the tracks turned toward the river. Our luck here deserted us. The elephant decided to recross, and made for the 
point at which it had crossed the river the night before. This was the spot at which we had joined the tracks in the morning, and where we had left our boat.

As the elephant stepped down into the river, in a fury at the sight of any implement of man, it seized our craft and swung it out of the way, snapping the iron chain by which we had tied it to a tree, and sending it adrift down the stream.

When we arrived on the scene we only found a few links of a chain on the near bank, and in the distance saw the huge footprints which showed where the elephant had clambered up the farther side. The river was not particularly broad, but it was tidal mangrove water, and infested with crocodiles. To cross it without a boat was out of the question. We had the alternative of taking a path back through the forest, making for Brahim's house, which was some three miles away, or of waiting on the chance that some boat might pass. To return was to give up all hope for the day. We therefore decided to wait; but luck was against us. For nearly three long hours did we wait upon a slimy bank, grilled in the sun and devoured by mosquitoes, mocked by the glitter of undrinkable water and insulted by the footprints fast drying upon the opposite bank. At last, at about five o'clock, a boat came round the bend of the river and took us off. It was too late to follow the tracks farther, and I sadly gave the order to return to the house-boat.

It was not until after dinner that I heard of the accident to which I owe my life. Both Ahman and 
Sleman swore positively that when I fired my second barrel at the charging elephant an enormous rotten branch, loosened by the concussion of the shots of my heavy rifle, fell from the tree under which I was standing. As the elephant charged down the path, the great branch fell fair upon its back. It was this that had stopped the elephant's charge, and not, as I had imagined, my second barrel. If their story is true, and I see no reason to doubt it, it was a marvellous chance that the branch, which would have killed me had I remained where I was for a moment longer,' should have saved my life by falling upon the elephant.

I ordered the house-boat to be taken down to the point where the elephant had crossed and recrossed; and we were drifting lazily with the stream, and consoling ourselves with the day's want of success by an assurance of the certainty of meeting the elephant again on the morrow, when suddenly we were hailed out of the darkness by a police-boat-

"Amok! amok!"

When the boats approached one another a corporal came on board and reported that a Malay had run amok, killing his wife and two men. The scene of the murders was on the sea-coast, not far from the border between my district and an independent native state; and the murderer, who had escaped into the forest, would undoubtedly make for the border. The sergeant and a posse had already left in pursuit.

There was no police inspector in the district, and therefore no option was left me. I took the police 
crew on my boat, and with a double set of men we paddled hard for the river mouth. By midnight we had transhipped into the Government yawl, and a few hours later were out at sea, skirting the coastline to make for the Kemaman border.

We eventually caught our man; but it was some time before I could find time to return to the Blat river. It was then, of course, out of the question to follow the tracks that we had left, and all that I could do was to organise parties to search in all directions for any signs that there might be of the elephant's dead body. But all in vain.

The next month I left Kuantan on transfer to another district, and shortly afterwards proceeded on a long leave to England. Soon after my arrival at home I got a letter from Ahman to say that a Malay rattan-cutter had come upon the dead body of the elephant, and had stolen the tusks and sold them to a Chinaman over the Kemaman border. I wrote to my successor about the matter, but the lapse of time made it impossible for him to do anything; and that, I am afraid, is the end of the Blat Elephant.

It is satisfactory so far as Brahim and the cultivators of the Blat and Sol rivers are concerned, for they have, I hope, killed the goats and buffaloes that they vowed to slay; and unless a new elephant has appeared to take the place of the old one, their crops are safe.

But where are the tusks that I should have to grace my story? I sigh to think of them lying in a shop-window, cut up into hair-bushes or frittered 
away to be the fittings of a dressing-case. For in my dreams I see them as I shall never see them again, gleaming in great curves, with an overpowering bulk of head and body behind them, and framed by a veil of green rattans torn asunder to right and to left. 


\section{A TIGER-DRIVE.}

IT is grey dawn on the banks of the Perak river. The little Malay owl has uttered its last kû-hûp; in every tree small birds are twittering and fluffing their feathers to warm themselves, and on all sides the jungle-cocks are shrilling a cheery defiance to one another. Sunken under an accumulation of ghost-like mists, the wide expanse of river lies pallid, drear, and chill. A faint saffron light in the east enables one dimly to discern upon the river bank a number of scattered dwellings, such as constitute a Malay village, and at the water's edge a long line of tethered house-boats, prahus, and dug-outs. One by one Malays rouse themselves from sleep, and, with eyes and brains still heavy with slumber, pull a scanty cotton cloth over shivering, rounded backs, and make their way to the river, where they perform their morning ablutions and repeat the morning prayer of the Muhammadan.

A few minutes later a glory of gold touches the saffron sky, tinges it, suffuses it, absorbs it-and there is day. The sun springs above the horizon, shows his clear disc above the distant forest-covered 
mountains, and throws long horizontal shafts of light and warmth that dance upon the sparkling river, and set coursing anew the blood of man and beast.

The morning breeze blows down the river, and gently wafts to one side the vapours that all night long had lain upon the surface of the water. A great bank of mist-a most beautiful thing maligned by the hateful names of miasma and malaria-now stands upon the river bank. A cloudy mass, its base rests upon the plain, and its summit makes a straight line against the background of a mountain-range. As the rays of the morning sun permeate it, it gently rises, still one mass, from the plain, and not many minutes later lies half up the mountain-side, horizontal, like a great grey sash that cuts the mountain in two. There it remains a few minutes, rapidly dissolving into thin streaks like wind-blown smoke, and almost before one realises that it is disappearing it is gone.

On one of the house-boats, whose Union Jack at the stern shows that she carries the District Officer, the servants are laying breakfast, and preparations of a similar nature are going on in the next houseboat, whose flag of royal yellow betokens the presence of a member of the Sultan's family.

It was known that there was a tiger in the bluker, or secondary forest, behind the village. For the past week it had been heard roaring day and night, and the sound had always come not only from one direction, but from one place. The Malay said that it was a tigress which had taken up its abode in one particular part of the forest, under some shady 
thicket or by some overhanging rock, whence it was calling to a royal wooer. The patch of forest in which it lay was so situated that it could be beaten without much difficulty; and it was in answer to an urgent message from the local chief, who was confident that he could show certainly one and probably two tigers, that the Sultan's son and the District Officer had got up a party of guns, and had made the other necessary arrangements for a drive.

A youth seated himself at a great brass gong hung in the raja's boat, and began to beat the assembly call. Before long a distant boat was seen to shoot out into mid-stream, and to move in the direction of the sound. Then on all sides the bright surface of the water became dotted with black specks of various size that all converged on the one point. The Malays whose houses were near at hand collected in small groups upon the bank, and round the landing-place prahus and dug-outs clustered thick. Some held only a poler and a steersman, while others were laden to the water's edge with a crowd of Malays perched in ungainly bird-like attitudes, but in apparent comfort, upon the bare inch or two of the free-board. By the time that the party, of whom the writer was one, was ready to step on shore, some two hundred Malays had mustered on the bank. In this throng of men there was not one who was not armed. Nearly every man held a spear, many carried a dagger, or kris, as well, and not a few showed a waistbelt loaded with an assortment of weapons that would not have disgraced the most piratical of 
marauders. The spears showed that a tiger-drive was contemplated, for across each, some eighteen inches below the point, a little piece of wood was lashed on at right angles to the shaft. This crossbar is intended to prevent a wounded tiger from clawing its way up the spear-head that transfixes it, to the man that holds the spear. Such men as owned, or had been able to borrow, a small dagger of a peculiar shape known as a golok rembau, exhibited their weapons with complacency and pride; for these daggers are supposed by the Malays to possess such extraordinary, even magical, properties that a tiger is powerless against them.

When the local chief announced that everything was ready, an old pawang stepped forward with a bunch of twigs of a tree for which a tiger is thought to have a peculiar dread. Holding this small bundle in both hands, he repeated over it the charm known as "that which closes the tiger's mouth," and then, after another incantation which was intended to prevent the tiger from winding us, proceeded to break the twigs into short fragments, which he distributed first among the shooters, and then among the beaters. The ceremony did not take long, but by the time it was over, and the final words of advice, exhortation, and command had been said on every side, the sun was strong enough to make the shade welcome; and without further delay the old chief led his picturesque throng of beaters down one path, while we set off along a track that took us into another part of the forest. 
The direction that the drive was to take had been decided upon some days before, and a line along which the guns were to be stationed had already been cut through the forest. The line was broad enough to afford a fair shot, and had been more or less cleared of undergrowth and obstacles. For the benefit of those who do not know, I may say that such a line is not, or should not be, a straight one; for if the guns are all in the same straight line, each man stands an excellent chance of being shot by his neighbours in the excitement of the moment.

The line should be a succession of V's touching one another: a man standing in the angle of the $\mathrm{V}$ can then shoot down both sides with perfect safety. If there is time, and the ground is not unnecessarily disturbed thereby, a double line of V's may be cut back to back so as to form X's; and each gun then commands four lines, and when an animal has crossed the first line often gets an opportunity of another shot at it on the second line. To what extent the knowledge that he and his neighbours can fire in perfect safety improves a man's shooting, only those know who have endured the mental agony of standing in a row of guns where it is not inconceivable that a single bullet may pick off three men. In the zigzag line there is the further great advantage, which makes for good shooting, that an animal is rarely visible to two guns at the same time, and that, therefore, there can be no doubt as to who should fire.

The party consisted of nine guns-six Europeans 
and three Malay rajas,-and for each there had been erected in a tree a small platform made of lopped branches bound together with green rattans and screened with leafy boughs. The object of the platform is partly to keep the shooter safe above any danger from the tiger, but partly also to enable him to obtain the best possible view of the ground and to prevent the tiger from scenting him.

As soon as we had scrambled into our individual platforms, the Malays who had been our guides swarmed up adjacent trees, and, having first made sure that they had not intruded upon a nest of the great vicious red ants, selected comfortable perches from which to await the result of the drive. The beaters formed into line at a place some two or three miles away from the posts taken up by the guns. The forest that they had to beat out was a strip comparatively narrow in proportion to its length, lying between a Government bridle-path on the one side and a deep swamp on the other. It was most unlikely that the tiger would attempt to break out at the sides of the ground, and therefore no stops were posted.

We had not been long in our places when the preconcerted signal of a shot announced that the drive had begun. It would, however, be another two hours at least before the men would arrive at the line of guns,-for beating in dense forest, if thoroughly carried out, is very slow work. Deep silence reigned throughout the part of the forest in which we were, - a silence enhanced by the faint distant sounds of the occasional war-cry of the advancing Malays. A 
peacock-pheasant, whose persistent scolding clatter, not unlike the note of a cackling barn-door hen, had warned every animal within hearing of our arrival, had ceased its clamour at last and recommenced its scratching among the fallen leaves. Two little birds-the male a brilliant black with a golden crown, and his mate a sober russet-brown-resumed the labour of feeding their speckled nestlings. A resplendent ground - thrush, gorgeous as a salmonfly, which on our approach had hidden under some fallen leaves, had now regained its confidence and came hopping out to continue its search for food. The life of every animal seemed to be a silent one. In the distance, it is true, a great rhinoceroshornbill called from a tree-top to a mate afar off; and high overhead, hidden in the blinding blue, a kite uttered at intervals its shrill, querulous whistle. But these were the exceptions: at all hours and at all seasons the silence of the animals is one with the silence of the forest.

During the whole of the drive no animal larger than a mouse-deer appeared within sight of my platform, and when finally the line of beaters reached the guns we found that the drive was a blank. A sambar and a barking deer or two had been seen by the other guns, but, since a tiger was our object, no one had fired at them.

The Malays were not only disappointed but much surprised at the failure of the drive. Day after day and night after night the tiger had been heard roaring in the area through which they had just beaten, and they could not understand why not a 
sign of it had been seen. They were positive that, since it was not in the ground which they had just covered, it must be lying up in a smaller strip of forest between the bridle-path and the Perak river.

After some short deliberation and argument they went off without further delay to drive, and we stationed ourselves at intervals through the forest. There was no time to clear any lines nor to erect platforms in the trees. We took up positions on foot, arranging ourselves in such order as we could, and each man knew, though he could not see, the situation of his neighbours on either side. At the place where the beaters formed into line the bridlepath was about a mile from the river; while at the point where guns were stationed, about a mile farther up-stream, river and path were within three hundred yards of one another. The ground to be beaten was thus a triangle: the beaters were at its base and the guns at the apex. Behind the line of guns river and path diverged again, and between them lay a vast expanse of dense, heavily timbered forest for which it was thought that the tiger would make. We had not been long in our places before the beaters began to advance towards us. I studied the lie of the forest in my vicinity and the approaches by which an animal would be likely to come in my direction, and then fell to watching an interminable string of little black ants at my feet. They were migrating, but I could not see whence they came or whither they were going. The line that they followed was extraordinarily devious : up one side and 
down the other of a tree-stump, round three sides of a great boulder, over and along surface-roots, under a fallen log the black line twisted and turned. There seemed to be no attempt to shorten or to improve upon the winding path selected by the leaders of the column. The little creatures moved in a line some six or seven deep; and for some reason which it was difficult to discern, a constant succession of ants kept hurrying back through the ranks to communicate with the rear.

Suddenly there was a cry afar off: "Look out! The tiger is here!" How every feeling intensified at the sound! Not a soul was within sight; but one knew that the men who were hidden to right and to left had heard the words, and had thrilled to them no less than oneself. The beaters were yet more than half a mile away, but it was not difficult to imagine the excitement that possessed them. Somewhere in the area encompassed by them and by the guns there was moving silently through the dense forest undergrowth the lithe powerful form of a tiger. We all knew it: it even seemed strange that the long string of ants should fail to know it and should continue their unheeding ceaseless hurrying. Somewhere near us the tiger was or should be.

At the shout the men steadied themselves, moving to one side or the other in order to make the line of advance as perfect as possible. There was silence for a moment, and then a great voice shouted, "Selawat!" (prayer). "Selawat!" shouted every one; and thereupon one of the men in the long line 
chanted aloud some verses of the Koran, concluding by shouting at the top of his voice the words of the creed of Islam: "La' ila'hu illa' llahu; wa Muhammadu'r - rasulu' lláhi" (There is no God but Allah, and Muhammad is the prophet of Allah). And from every voice in the array that was hidden up and down the forest came the roar of the response of the final Allah. Apart from its religious aspect, the use of the "selawat" is to enable the men to know whereabouts in the denseness and tangle of the forest undergrowth the animal is hidden. If a tiger is suddenly disturbed when lying up beside an animal that it has killed, or has cubs, or is wounded, or is for any other reason savage, it often gives utterance to an answering challenge which it not infrequently follows up by charging forthwith upon the men. I have more than once heard a sudden vibrating roar in reply to a cry of "selawat" that has made the blood of the listeners run warm; and more than one Malay has been struck down with the expression of his faith upon his lips.

On this occasion there was no reply to the longdrawn Allah, and after a pause, during which each man assured himself of his position with regard to his neighbours, the array of beaters slowly and carefully moved forward. At intervals the piercing war-cry of the Malays rose and rang up and down the line. Occasionally an order was shouted to close in on the right or to move up faster on the left, but otherwise the advance was made in greater silence than might have been expected. The men worked out the 
thickets with their spear-heads, and rapped their spear-butts upon the tree-trunks with a steadiness and thoroughness that would have been creditable in any pheasant covert in England. They were, I may say, an exceptionally fine set of men. The Malays of Saiong are famous throughout Perak for their skill and daring in a tiger-drive; and on this occasion they were under the eye both of their Sultan's son and of the District Officer.

Before long the cry arose again, "Here he is! Here he is!" Upon this the old chief in charge of the drive shouted an order, "Tahan, tahan!" (Steady, hold steady !) Down on a knee dropped every man of the two hundred that composed the line. Close to his side each man gripped his spear, with its point thrust upwards into the dark forest undergrowth in front of him. It was impossible to see the plainest object at a distance of more than twenty yards, and a tiger might crouch unseen within three yards of the most vigilant. Little doubt that each man eyed the crossbar on his spear, and thought how very small and very near him it looked; amid the safety of the crowd in the village he had tied it on with a pleasurable titillation of excitement. But now its significance was very real and very grim.

The chief shouted his order to the men to stand steady, because he thought that, as the tiger had not by this time passed the guns, it must be aware of their position, and intend to seek safety by breaking back through the line of beaters. Every one knew what the chief thought, and waited, peering into the dark forest in front of him, in readiness for the next 
word of command. Then the chief shouted again. All leapt to their feet, ran forward a few yards-five or six, perhaps, or it may be even less-and then as suddenly stopped and knelt again. "Steady! Hold steady!" they shouted up and down the line, while all strained their eyes to catch a hidden gleam of yellow in the heavy shadows of the black and green of the forest. Thus they advanced in short quick rushes with sudden pauses, until they were within two hundred yards of us. The excitement by this time was almost overpowering in its intensity. I could not, of course, see the men, but knew by the sound that only this distance separated us, and that on the other side of the thickets and tree-trunks in front of me fierce Malay eyes glared and peered for the hidden tiger. Then suddenly, in a tree half-way between the beaters and the guns, as quirrel raised its chattering note of alarm. Another squirrel immediately took up the cry, and the pair of them kept up such an incessant excited clamour that it was plain that they were scolding an intruder; it was obvious, too, that the intruder was within a few yards of them. The tree from which they uttered their defiance was situated in a ravine-like depression in the forest, exactly the sort of place in which a tiger, or any animal, would seek a refuge from the invasion of the beaters. The chief shouted to the men to move in upon the place, and the long line swept inwards and enclosed it in a semicircle. By this time the length of the line had so contracted that the men were nearly shoulder to shoulder. Only a hundred yards or so separated them from the guns, and it was 
therefore practically impossible for any animal between them and us to escape. The Malays now advanced foot by foot, and in an almost breathless silence. Then I saw something move stealthily under a fallen tree, whose dead leaves prevented me from getting more than a glimpse of it, and that, too, a glimpse not so much of it as of the place from which it had stirred. It saw me as soon as I saw it, and, knowing itself to have been discovered, a great, gaunt, wild sow rushed out and dashed past me. The nearer of the beaters heard it and dropped on their knees, with their spears thrust forward to receive it. "Here he is! Here he is! Steady! Hold steady!"

For a space not a man moved : probably not a man breathed. Then I shouted that the animal that had come out was only a pig, and that the tiger had not yet shown itself. "Pig," they roared up and down the line, "only a pig"; and again the line moved forward to beat out the few remaining yards that separated them from the guns. But when they reached us not a sign was there anywhere of the tiger.

Excited questions were yelled on every side. No one knew what had happened. What every one failed to understand was why no one had fired. The men thronged round the place where the old sow had passed by me, and leant upon their spears examining the tracks and mournfully shaking their heads. Their heaving chests, twitching muscles, and unnaturally contracted eyelids told of the intense nervous strain which they had undergone.

Had any one seen or heard the tiger, and who had 
first raised the alarm? In reply to this, several men spoke to having heard the tiger, but no one had actually seen it. Every man of them indignantly repudiated the suggestion that he could have mistaken a pig's grunt for a tiger's growl. Malays know the two sounds so well that such a mistake would be most unlikely. Some pigs had been seen, but no one had taken any notice of them. When we asked the men who declared that they had heard the tiger how they accounted for its having escaped unseen, they pointed out that when the squirrels had given their alarm we had all taken it for granted that they had seen the tiger, whereas it was probably only the sow, and that when the beaters closed in upon the ravine they had left the forest on either side unguarded. This, of course, was perfectly true, and their explanation of our failure was probably the correct one.

Some of the more enthusiastic of the Malays proposed that the ground should at once be beaten over again; but midday was past, and it did not need a second glance at the majority of the men to see that the excitement, rather than their exertions, had so exhausted them that they were not fit to undertake another drive. Moreover, even if the tiger had really been in the ground covered by the first drive, it by no means followed that it would be there by the time that the beaters were ready to line up again. We decided, therefore, that we must give it up. We covered our disappointment as best we could; but our long high-strung excitement had had such a miserable ending that one might have noticed an 
almost hysterical catch to the laugh of more than one man.

This was the most sporting tiger-drive that I have ever seen. The fact that no tiger was seen, and that possibly no tiger was near us, does not in any way detract from the sport. We all believed that the tiger was there: the guns thought that a tiger which was aware of their presence was being forced to come towards them; and the beaters felt that they were impelling forward an animal whose desire was to charge back through their ranks. If the drive had ended by a tiger being shot, it would not in the slightest degree have added to the excitement that marked the duration of the drive. I have shot a tiger in a drive that had not a tenth of the interest of this day. Accompanied only by Malays, I have occasionally had to follow wounded tigers on foot through nasty country. As I have said above, I have heard the "selawat" answered in royal style; but nowhere else have I seen such an intensity of feeling and excitement. With this the number of men employed had a great deal to do. It is seldom that one requisitions more than thirty or forty beaters, whereas in this case fully two hundred men were engaged. The amount of magnetic feeling, where the excitement was communicated from unseen unit to unseen unit throughout the forest, was enormous, and the air vibrated to the unuttered excitement of the men.

It is in a drive where a line of men armed only with spears advances thus determinedly upon a tiger, that you realise how powerful a brute it is that they are assailing. From the height of a seat in a 
tree or an elephant's back you may shoot tigers with safety; but when you come down to the ground, and either advance on foot to meet the tiger or wait on foot for it to be driven up, the feeling comes home to you of the marvellous strength and activity that are combined in that beautiful frame. It may be within a few yards of you, perhaps, seeing all that you do, and itself unseen. It can steal noiselessly through the forest where you can only move with crackling of leaves and breaking of twigs. You know that, when the occasion comes, that wonderful lithe body can come with lightning speed through the thick-tangled growth that hampers and impedes your every movement. Finally, you know that at close quarters a man is as helpless as a child against the overpowering weight and strength of an animal that kills an ox at a blow.

When you are on the ground following up or waiting for a tiger, you realise all this with some vividness. And in this connection I would advance the theory that the curious horror which some people have of cats is not, as is sometimes said, a sixth sense, but merely an instinctive terror, inherited from simian ancestors, of the feline tribe. The instinct has, I suggest, died out in the majority of cases, but exists in occasional individuals in the same manner that simian tricks of raising the ears or eyebrows are sometimes to be seen.

But whatever the average person's feelings may be regarding the race of cats, there is little doubt that almost every one has a peculiar sensation of the almost god-like beauty, power, activity, and strength 
of a tiger. A tiger will overawe and make conscious of his inferiority a man who would be unaffected by the bulk of an elephant. The feeling is, however, elusive of description, and I can perhaps best explain it in the words of a most charming French gentleman (now dead, alas!) who was once manager of a great tin-mining company in Perak. I well remember his coming into the Tapah messroom where the Europeans of the district used in those days to take their meals. We had just finished lunch when he entered in a state of tremendous excitement. Walking alone and unarmed along an unfrequented bridle-path through the forest, he had walked almost on to a tiger. He gave us a most vivid narrative of the encounter: how the tiger had been lying down concealed in some long lalang grass beside the path; how he was within ten yards of it before he saw it; how then it rose and looked at him; how it yawned at him; how it then walked slowly across the path in front of him, and then stopped and looked at him, again yawning; and how it then deliberately walked away into the forest, whose depths finally hid it from view. I cannot attempt to imitate the beautiful and forcible diction that Monsieur C. had at his command, for the plain facts that I have thrown into a single sentence received from the narrator a majesty of style and a wealth of colouring and detail that cannot be reproduced on paper.

Some one asked him whether it was a big tiger. It is his answer that illustrates my meaning. "Well, Messieurs, I cannot say if he is a big tiger. My eyes see that he is big; but I cannot say how big 
I see him to be; and if I say how big, it is perhaps that I tell you a lie. But I can tell you, Messieurs, how big I feel him to be, and I can tell you the truth. When he is standing there in front of me, I tell you that I feel he is not less than thir-r-ty feet high." 


\section{A TALE BY THE WAYSIDE.}

ONE of the charms of shooting is that one's wanderings with a gun, be it rifle or smooth-bore, generally take one into the remoter parts of a district where the Malays are still almost unaffected by the progress of civilisation, and where they live very much as their fathers lived before the days of roads and railways. When one rests for a few minutes, or hours, or for a night, in a village, not only does one see the simple and natural side of Malay life, but has a glimpse of the more intimate side; and one becomes acquainted, in a casual way, with much that one would never learn in an official visit. There is something in a gun that is like the incognito of royalty,-it shows that the bearer is not on duty; and when a man is in a stained and disreputable old shooting-suit, it is easy for him to forget, and to persuade others to forget, that he is the Judge or the District Officer.

When you listen to Malays talking naturally among themselves, the thing that will most puzzle you will often be the apparent inconsequence of the remarks, the looseness of the argument, and its curious inherent tendency to drift into yet further vagueness. It will not be until you are thoroughly acquainted with the 
language and with Malay habits of thought, that it will dawn upon you that the thing which is bewildering you is an airy allusiveness, and that you have not got the key to the allusions. You will probably have been some years in the country before you realise that a Malay considers it crude to say outright what he has in his mind, and that he will prefer to let his meaning be known by a reference to a proverb' a quotation of a line of rhymed pantun, or a hint at the moral of a folk-tale.

This allusive style of conversation (regarding which I would like to digress for a moment, for I think that it will afford a clue to a riddle that puzzles many people) reaches its most exaggerated and fantastic form in the quotations from the pantuns, which are rhymed quatrains whose third and fourth lines alone carry the sense, while the first and second lines supply the rhymes.

Here is an example in which the translation is in the metre of the original :-

"The fish fry play in the shallows,

While the big fish swim without.

Tell me, beloved, the truth at once,

For my heart is tortured with doubt."

It is part of an amatory song, but in a serious discussion among the village elders you may hear a man say slowly and thoughtfully-

"The fish fry play in the shallows ;"

and though, of course, the words convey no meaning to you, unless you are acquainted with the pantun, 
you will see that the meaning that the speaker has intended to convey by the unquoted third and fourth lines has been perfectly appreciated by his audience.

There may be silence for a short space, and then perhaps another man will open his mouth to speak. You will notice that he has carefully considered his words, but

"White, pure white, are the river sands,"

is all that he will say. However, every one at once understands that his meaning is-

"You may say too little or say too much,

You can remedy one, but never the other."

Overtures, insults, challenges, may in like manner be conveyed in such lines as-

"The reed stems sway in the rippling stream."

"The green pigeons feed on the fig-tree's fruit."

"The cataract leaps through clouds of spray."

An argument by quotations from pantuns partakes, however, more of the nature of a contest of wit than of a genuine discussion. Similes and metaphors borrowed from the proverbs, of which the language has a rich and varied store, are more common and more easily understood. But the fact that arguments can be carried on in such a manner shows how apt the Malay is to speak allusively, and how quick to recognise the allusion. When, therefore,-this is the point to which my digression led,-a Malay is discuss- 
ing with an European a matter of considerable importance to one or both of them, the European will often wonder when on earth his man is going to come to the point, while the Malay is only thinking whether he can say any more without being so brutally direct as to give offence.

The folk-tales, rather than the pantun or the proverbs, are the medium by which a Malay loves to make his meaning known.

In the village council, when weighty matters are under discussion, many an argument is clinched or moral pointed by an allusion to a story that in our prosaic land would come under the half-contemptuous heading of "children's stories," but which in the East are treated as parables.

The little wayside tale, to which these remarks must serve as an introduction, may perhaps gain some dignity if I mention that many years ago it was told at length in the Perak State Council, and that a very important decision was based upon it.

The Malays have a wealth that has been almost unexploited of folk-tales. There is a number of stories of which $\mathrm{Pa}$ ' Musang (Father Civet Cat) is the central figure; another series is grouped round $\mathrm{Pa}^{\prime}$ Bilalang (Father Grasshopper); and there is yet another set of stories about $\mathrm{Pa}^{\prime}$ Pandir (Father Pandir), the typical buffoon or fool, who invariably does the wrong thing, manages to twist the most ridiculous meaning out of the plainest instructions, and always finds some means to make the most absurd mistakes.

But of all stories, the most numerous, the best 
known, and the most popular, are those that have for their hero the little mouse-deer, whose Malay name is pelandok. ${ }^{1}$ It is the smallest of all the deer tribe, -the daintiest and most exquisitely formed little creature that can be imagined. A full-grown animal is barely eight inches high ; and so small is the scale upon which it is built that its feet, with their delicately cloven little hooves, have not the thickness of the slimmest of penholders.

No one, so far as I am aware, has attempted any analysis or classification of the mouse-deer stories. They seem to contain three separate conceptions of the character of the mouse-deer, and though no hard and fast line of division can be drawn, most of the stories fall into one of the three classes.

First of all, we have "the wily mouse-deer" pelandok jenaka - the trickster, the practical joker, often the petty cheat. He is the counterpart of Reynard the Fox in the stories of Central Europe, of the Jackal in India and in East Africa, and of "B'rer Rabbit" in negro tales. He escapes from an enemy by his cunning, but he is generally powerless to destroy his enemy; he contents himself with mocking at his discomfiture, generally quite needlessly, rather in gamin fashion, and thus only succeeds in whetting a natural desire for revenge.

Of this class are the following stories:-

A mouse-deer one day fell into a trap, and being unable to get out again waited there until an elephant happened to pass by. Then the mouse-deer called out —"Why, brother elephant, what are you doing?" 1 The final $k$ is silent : pronounce pělăndo. 
The elephant stopped and inquired what the matter was, and what the mouse-deer was doing at the bottom of the pit. The mouse-deer exclaimed-

"What, you foolish elephant, have you not heard that the sky is going to fall? I am staying down here to be out of harm's way."

The elephant replied that he had not heard anything about it, but at the mouse-deer's suggestion he looked up above his head, and there, between the treetops and the sky, he saw the clouds scudding by.

"See how the clouds are flying," cried the mousedeer. "It won't be long now before the sky falls."

The elephant looked again, and then, without further parley, plunged into the pit for safety.

The mouse-deer then managed to get on to the elephant's back, and thence to leap up to the mouth of the pit and to make good his escape.

He was then mean enough to go and tell the man who had made the pit: which is somehow rather disappointing.

Another time the mouse-deer wished to cross a river, but dared not swim it for fear of the crocodiles that infested it. He had therefore to rely upon his cleverness, and accordingly got into conversation with the Crocodile Raja, who lay basking upon the bank, and started a discussion as to whether there were more crocodiles or mouse-deer in the world. In the course of the argument the Crocodile Raja said that there were more than a thousand crocodiles in his river alone, and the mouse-deer expressed his surprise that there should be so many crocodiles in the whole world, and suggested that the Crocodile Raja should 
call up all the crocodiles of the river, so that the mouse-deer might count them.

This was agreed to, and soon all the crocodiles in the river floated to the surface. At the mouse-deer's suggestion they put themselves in a row, so that they might be more easily counted, and the row extended from one bank to the other. Then the mouse-deer began to count. "One," he called out as he jumped on to the back of the first crocodile; "two," and he jumped on to the back of the next one; "three," and so on until he reached the other side of the river.

When he was safely upon the bank he turned and jeered at the deluded raja in front of all his subjects, and then gleefully continued his way skipping through the forest.

Another time a crocodile caught the mouse-deer by the hind-leg, which is such a marvel of fine-drawn skin and shapely bone. The mouse-deer saw that any struggle to escape would be fatal, and while with his other three legs he endeavoured to maintain his hold upon the bank, he called to the crocodile-

"Ha! you missed me that time."

"I think not," snuffled the crocodile, with his jaws clenched upon the poor little leg; "I've got you by the leg."

"Leg!" laughed the mouse-deer, suppressing the agony he felt; "that is no leg you are biting. You are holding on to an old dry twig."

The little leg that the crocodile held was as fleshless as any twig; and the crocodile believed that he had made a mistake, and opened his mouth, thus allowing the mouse-deer to escape. 
On another occasion the mouse-deer challenged the crocodile to a tug-of-war, - the crocodile to pull from the water and the mouse-deer from the land. The mouse-deer tied his end of the rope to the top of a coco-nut-tree, and then gave the word to pull. The crocodile tugged with all his might, and the palmtree swayed to and fro. When the crocodile, swirling in a turmoil of water, pulled his hardest, the palm yielded and bowed towards him; but when he relaxed his efforts for a second, the palm resumed its natural position, and the crocodile lost the few feet that he had gained. So it went on, and after a while the mouse-deer called from the bank, suggesting that they should wait for a breathing-space.

The exhausted crocodile agreed, and the mouse-deer came lightly leaping down the bank.

"That was a splendid pull," he said cheerily to the crocodile. "You are better than I had thought, but I'll get you over easily next time."

The crocodile could hardly speak for lack of breath, and when he saw that the mouse-deer showed no signs of fatigue, he declined to continue the contest, and admitted his inferiority.

But it is not only the crocodile that the mouse-deer scores off in this fashion. He is always getting the better of the tiger, the elephant, and all the other animals, in the same sort of way. The stories are generally very slight, and, as I have said, they do not always show the wily mouse-deer in a very favourable light; but somehow the little creature has a charm that is peculiarly his own. If he is undoubtedly a trickster, he is without doubt a very fascinating little 
trickster; but the whimsicality that underlies this charm is so evanescent that it will not live in pen and ink. The stories can only be told. When one has committed them to writing, even in their native language, one cannot but look at them with the same rueful feeling that a man has when he has picked a wood-anemone and sees it fade and wilt at his touch; but when one has to translate the story into another language, in which the words have another value and therefore fail to give the true equivalent of the original, the result is no more like the real folk-tale than a flower, dried and pressed between two sheets of paper and labelled wood-anemone, resembles the white star that raises its delicate head above the fallen beech-leaves.

In the second of three divisions into which the pelandok stories may be said to fall, the little mousedeer appears in the character of an arbitrator or umpire, chosen on account of his acumen to settle disputes and quarrels. In this rôle he is generally styled Che Salam di Rimba (Sir Peace of the Forest), and is addressed by all with respect.

Of this class of story the following will serve as an example.

Two men (men, be it noticed) quarrelled about a loan which one had made to the other. The debtor had promised to repay the loan in two months. (In Malay, moon and month are the same word.) When, upon the expiry of the stipulated time, the creditor demanded repayment, the debtor replied laconically, pointing to the sky, "There is only one moon."

"It is two months since I lent you the money," 
replied the creditor, "and you promised to pay in two months."

But "there is only one moon" was all that he could get out of the debtor.

So the creditor went home and waited another month. Then he went again to demand his money, but "there is only one moon" was all that the debtor said.

"You said that last time," cried the creditor, "and that was a month ago."

"Only one moon," replied the debtor; "when there are two moons I will pay you." So they quarrelled. Then to settle the dispute they went to Sir Peace of the Forest.

Sir Peace heard both men state their cases, and then, when the sun had set, took them both down to the river-bank. It was a cloudless night, and upon the bosom of the river the full moon shone reflected.

"What is that?" said Sir Peace of the Forest to the debtor, pointing to the golden circle that lay upon the water.

"The moon," replied the debtor.

"And what is that?" said Sir Peace, pointing to the sky.

"The moon also," replied the debtor.

"That makes two," cried Sir Peace. "Two moons; and the time has come for you to pay your debt."

The debtor was silent. He had relied upon a trick, and the same trick had been used against him. He could find nothing to say, and was compelled to repay the loan.

The stories in this second class are not as numer- 
ous as the "wily mouse-deer" stories, and the only example will suffice. As a rule, the stories rather remind one of the Arabian tales of the wise Viziers and Kathis.

In the third class of story the mouse-deer has attained to royal rank and power. By his skill and address he has subjected the other animals of the forest, and all of them--elephant and tiger, sladang and rhinoceros-acknowledge him as their king. His title is Shah Alam di Rimba (the King of the Forest Universe), and he is addressed in the honorific forms appropriate to a reigning sultan. He has his throne upon a white marble rock under the canopy of a flowering bungor-tree, whose flowers nearest approach the colours of royalty; and when he travels, rides either upon a white sladang or a white rhinoceros. $\mathrm{He}$ is the champion of all the animals against their external foes.

I should like to tell the story of how he made the peace between the Tigers and the Goats, and constituted himself as their king-paramount; and the story of how he slew the Giant of Lake Tenom, after the giant had defeated the bear and the rhinoceros. But the tales are too long to tell here, and I must reserve for myself the pleasure of telling them at some other time.

In this third class of story the mouse-deer has a heroic side to his character that is denied to Reynard, "B'rer Rabbit," or 'the Jackal. The little champion somehow invites comparison with the hero of the Odyssey. The comparison may appear ridiculous, but in justification I would point out the epithets 
"of many devices" and "rich in counsel," which throughout the Odyssey are applied to its hero, exactly fit, not the mouse-deer in his rôle of champion, but the mouse-deer of the first and second divisions that I have attempted to make.

I must repeat that the division between the three classes of story is not clearly defined. Some stories fall half-way between one and the other; and the difficulty of attempting to classify them is added to in no inconsiderable measure by the fact that the Malays love the title of "Sir Peace of the Forest," which is appropriate only to the "counsellor" class of story, but at the same time prefer the simpler stories of the "wily mouse-deer" type, and the result is that, whether the story be of the trickster, the counsellor, or the champion, the little mouse-deer generally bears his whimsical title of Sir Peace of the Forest.

When you have a few minutes or half an hour to spare; on a river-bank, while you wait for a dug-out to convey you across to a teal pond or to a place where the green pigeons are flighting; under the shade of fruit-trees, beside the snipe-fields, while a boy climbs to get youlgreen coco-nuts; in some wayside shelter from the heat of the sun, while some one runs to call the dog-cart that is waiting farther down the road,-it is easy, if you go the right way about it, to bring into the conversation some allusion to Sir Peace of the Forest, and then, when you have either made some one tell the story or have told it yourself, nothing is easier than to get another man to cap it. 
The story which I set out to tell is properly speaking an animal story, pure and simple, and does not belong to the mouse-deer cycle. My preface is intended to explain, firstly, how much a part of a Malay's daily conversation and life these folktales are; and secondly, why in this story the little mouse-deer bears, for no apparent reason, his fantastic title.

This is the story. I heard it one day when we were resting in the forest near Teluk Kepaiang after a deer-drive. We had entered the forest early in the morning, and having found fresh deer-tracks, had disposed ourselves along some wood-cutters' paths at points where the deer was likely to break out. When we put the dogs in, a deer had dashed out, affording me a shot which I had missed. The deer was now some miles away, and while a couple of men were following the tracks to recall the dogs, we were lying in the shade of the great dark forest-trees waiting for them.

There were six of us : my brother Eric; Che Ngah Durani, the headman ; Ali and Sahak, two peasants ; my tracker, Malias; and myself. The Malays were all smoking their native cigarettes or meditatively chewing betel-leaf.

At intervals one of them would call to the absent dogs at the top of his voice-

"Doh! Doh! Doh!"

"Oh! Si Nibong!"

"Oh! Si Kumbang! Doh!"

While we were talking, Sahak took up a couple 
of fallen twigs, and in an absent-minded way beat on a dead crisp leaf with them, tapping as one plays a kettle-drum.

"Ah!" chuckled little Che Ngah Durani, "that is the war-drum of Sir Peace of the Forest."

We all laughed. The mouse-deer call to one another in the mating season by rapping their hindfeet on the ground, and the Malays decoy them by imitating the sound with two sticks in the manner that Sahak was doing.

"Ha! ha!" Che Ngah Durani laughed on, "and that is the way that Sir Peace of the Forest beat his war-drum when he killed the Otter's babies. Tell us the story, Ali."

And Ali thereupon, without hesitation or demur, told us the following tale:-

"One morning, Memerang the Otter was going down to the river to catch fish. She left her family of baby otters on the bank, and, before she went, begged Sir Peace of the Forest to look after them for her. This, of course, wás in the days when all the animals spoke a common language. Nabi Sleman [King Solomon] had, by appointment from Allah, authority and power over all created animals, and Nabi Noh [Noah] had charge of all the trees and plants."

"Yes ; but," interrupted Che Ngah Durani, " there were some plants that Nabi Noh forgot. Nabi Tuakal [the Chance Prophet] discovered that Nabi Noh had overlooked certain roots, and decided to plant them himself. The whole of the earth had 
been taken up by Nabi Noh, so Nabi Tuakal had no alternative but to plant these roots upon growing trees. He did so, and the orchids are the result, and they are in the charge of Nabi Tuakal, not of Nabi Noh."

After the interruption Ali continued-

"The Otter plunged into the river, and Sir Peace of the Forest.remained on the bank, playing and nibbling the young grass, and keeping an eye on the Otter's babies.

"Suddenly he heard 'tap-a-tap-tap-a-tap-tap -tap-tap.' He listened, and then heard it again, and recognised the notes of the drum of the Woodpecker, and the call was that of the war-alarm.

"You know Blato' the Woodpecker," Ali said, turning to me,- "the bird that lights on the treetrunks, and drums with his beak upon the bark?

"Well, of the birds of the forest the Woodpecker is the one that may beat the war-drum. And when Sir Peace of the Forest heard the alarm, he knew that somewhere killing was afoot, and he is as skilled at drumming on the ground as the woodpecker is at drumming on a tree, and among the four-footed animals of the forest he is the chief dancer and drum-beater.

"So he proceeded to spread the alarm, and with his little heels he tap-a-tap-tap-a-tapped on the ground, in exactly the way that Sahak played with those two twigs just now. But in his excitement he did not see what he was doing, and, before he realised it, all the Otter's babies lay dead, trodden flat under his prancing hooves. 
"Soon the Otter returned, and there was a terrible scene. Sir Peace of the Forest admitted all that he had done, but the Otter would hear nothing in extenuation, and went away to Nabi Sleman to obtain redress. When she reached the presence of the King she made the obeisance [which is made by Malays by raising the two hands, pressed palm to palm, to the level of the eyes] and said-

" Pardon, O King! Sir Peace of the Forest has killed thy slave's children, and thy slave would hear the order of the King.'

"Nabi Sleman replied: 'Never yet without a father and a mother was child begotten; and without an audience of both the accuser and the accused, never yet was justice done. Go, call Sir Peace of the Forest.'

"Then Nabi Sleman turned to his Bentaras [court officials] and said: 'We will hear this case at the palace by the mouth of the river. Let all the animals attend.'

"Later, in full state, Nabi Sleman repaired to the palace. All the animals were present. On one side of the palace was the sea, thronged with all the sea-fishes; on the other side was the river, full of the river-fishes; on the land side were the forest animals; and the trees were full of birds and butterflies.

"Then Nabi Sleman, ruler under Allah of all the animals, turned to the Otter and said, "Tell thy story.'

"And the Otter made the obeisance and said ; 'Pardon, $\mathrm{O}$ King! This morning thy slave, before going 
down to the river to catch fish, left her children in the charge of Sir Peace of the Forest. On her return she found them dead, trodden to death; and Sir Peace of the Forest admitted having done the deed. Thy slave would hear the order.'

"Nabi Sleman turned to the accused and said, 'Tell thy story.'

"Sir Peace of the Forest made the obeisance and said, 'Pardon, O King! What the Otter has said is true. But soon after thy slave had been left in charge of the children, Blato' the Woodpecker sounded the war alarm. And thy slave, as in duty bound, also sounded the alarm, and, in doing so, unwittingly trod on and killed the Otter's children. Thy slave only did his duty. The fault is with the Woodpecker for sounding the alarm.'

"'Let no one be judged in his absence,' said Nabi Sleman. 'Send for the Woodpecker.'

"The Woodpecker came flying through the air [Ali imitated with his hand the undulatory flight of the woodpecker tribe], rising and falling in lines, like the curves of a kris or a wave of the sea, and entered the presence and made the obeisance.

"Nabi Sleman said, 'Sir Peace of the Forest has killed the Otter's children, and ascribes the fault to thee, saying that the war alarm was sounded by thee. What is the reply to this charge?'

"Pardon, O King,' said the Woodpecker. 'It is true that thy slave sounded the war alarm. But thy slave saw Penyu, the River-turtle, leave the river. $\mathrm{He}$ was followed by all the river-turtles, and they all wore their coats of armour. As they ascended the 
banks in their numbers, they presented the appearance of an invasion of the country, and thy slave accordingly sounded the war alarm. The fault is with the Penyu, the River-turtle.'

" 'Because the branch brake when the Hornbill flew by,' said Nabi Sleman, 'who shall say that the Hornbill broke the branch? We would hear the River-turtle.'

"The River-turtle was in the stream amidst the throng of the water-dwellers. He scrambled up the bank, the sand flying to right and to left under his broad flat flippers, and made his way into the presence.

"He made the obeisance, and Nabi Sleman said to him, 'Blato' the Woodpecker has sounded the war alarm, and has given as his excuse the appearance of an invasion of the country by thy kin. What hast thou to say?'

"The River-turtle again made the obeisance and said, 'Pardon, O King! Thy slave saw that the river was full of turmoil and alarm. Udang, the Prawns, were ascending the river in companies and battalions, and all of them carried their long spears between their eyes. Sebarau, the Perches, were swimming up-stream in broad lines of array, and every one carried his bright war-sash across his body. And Jenjulong, the Garfishes, dashing hither and thither, followed close behind, and each of them carried his terrible pike. When thy slave saw in the river such signs of war and cruel death, thy slave and thy slave's kin left the river for the safety of the banks.' 
“'By the grace of Allah,' said Nabi Sleman, 'a stream is not without its bends and turnings. Send for the Prawns, the Perches, and the Garfishes.'

"The creatures named were all in the river in attendance on the court of the king, and when their names were called they approached the bank and made their obeisance. In answer to the questions put by Nabi Sleman they all replied with one accord, 'Pardon, O King! the River-turtle has spoken the truth. But no invasion was it-no array of warriors. It was that thy slaves were fleeing for their lives from the onslaughts of Memerang the Otter, who ever kills and harries thy slaves.'

"Nabi Sleman then turned to the accuser, now the accused, and said, 'Hah, Memerang the Otter, what sayest thou to this?'

"'Pardon, O King!' replied the Otter. 'It is true that thy slave harried the Prawns, the Perches, and the Garfishes. It is the nature of thy slave to feed upon them, and to feed thy slave's children upon them. And, moreover, it was to seek and to slay them that thy slave left her children with Sir Peace of the Forest.'

"Then said Nabi Sleman, "The case is clear. Hear now our judgment. Learn, O Memerang the Otter, that it is not the arrow, but he that draws the bow, that slays. The fault is with thee. Hadst thou not harried the Prawns, the Perches, and the Garfishes, the River-turtle had not left the stream, and the Woodpecker had not sounded the war-drum, and Sir Peace of the Forest had not, in spreading the alarm, killed thy babies. None but thyself is to blame, and 
upon none other can punishment rightly fall. Let the death of thy babies be sufficient punishment for thee. Go in peace.'

"Nabi Sleman then turned to the Bentaras and said, 'Our judgment is delivered. See that all the animals here present return in peace."

As Ali was describing the dispersal of the animals, Nibong, whose name meant "the brindle," burst in upon us.

It acknowledged our greetings with a short wag of a tail, and threw itself down in the dampest and coolest spot to be found, where, with heaving flanks, it gave itself up to the luxury of complete exhaustion.

A moment later we were joined by Kumbang, an old black pariah, whose Malay name meant "the beetle," but a most staunch and excellent hound withal.

When the two dogs had been stroked and patted for a minute or two, to show that we knew what they knew-namely, that the day's failure had been our fault and not theirs, - we made a move, and prepared to go homewards.

As a chance would have it, we had not gone far before Kumbang gave a sudden yelp, and dashed into one side of the path. A moment later I heard a rustle among some dead leaves in the thick growth in front of me, and there under a fallen branch I saw the small form of a pelandok. The descendant of animals that "once upon a time" had held the forest in sway now cowered in apprehension. Its ears were turned back to catch the sound of Kumbang on its 
track, and its great eyes viewed with terror the open line made by the path on which we stood. At my sign Malias held Nibong, and as the pelandok bounded across the path I had time to rush forward and seize Kumbang.

The Malays all thought that I objected to dogs trained to deer acknowledging the scent of so small an animal as a mouse-deer, and little Che Ngah Durani only half-guessed that he had hit upon the truth when he laughed and said, "It was only right that Sir Peace of the Forest should go free to-day." 


\section{TUBA FISHIN G.}

When I was stationed, some years ago, at Kuala Kuantan, I represented throughout a district of many hundreds of square miles, principally forest, all that the Malays understood of British Protection. My nearest European neighbours to the west could only be reached by two days' poling up river; southward, by a two days' journey on foot along the sea-shore. Eastward lay the China Sea, thundering upon a sandy beach within a mile of my door. Northward, over many hundreds of miles, through unprotected native states, there were no Europeans until Siamese territory was reached.

I was therefore fortunate in finding myself among an exceptionally fine set of Malays. One and all they welcomed any sporting expedition, and a whole village would turn out at the shortest notice to join in a deer-drive. So much did they enter into the sport and identify themselves with it, that the idea of being paid for their work never occurred to them. Between associates there is no question of remuneration, and if I had offered them money they would at once have felt that I looked upon them as servants rather than as my fellows. All that they asked was, that if it were 
necessary for them to sleep away from their homes I should provide them with food. Never, if I had given due notice to the village headmen, had I any lack of men for a deer-drive; the difficulty was generally to turn back the lads whose strength was less than their keenness. But these Malays would work as well as play. One day, on the way to a deer-drive, for which the men of two villages had turned out in force, we had to pass through a deep swamp, some three-quarters of a mile long, between the two villages. We had a good day's sport, getting two splendid deer, and when it was over I told the two village headmen that they ought to build a light trestle-bridge across the swamp. They both agreed that it should be done, but all said that it would cost too much. I thereupon proposed that the men of Gebing should make half the bridge and the men of Pengorak the other half, every man in each village making his share, and promised for my part to provide the workers with food. My offer was accepted on the spot. A few months later the bridge was built, and well built, at a cost to the Government of some four or five bags of rice. And though it is some years now since I left the district, I am told that the bridge is still known by my name. This spirit of willing work is not, however, I am sorry to say, typical of the Malays as a race.

I had been an honoured guest at a great seine fishing held out at sea to inaugurate the first wetting of a set of nets, and Ahman, my head boatman, hinted to me that, by way of returning the hospitality, I should hold, for the benefit of the whole district, a 
tuba fishing of one of the rivers. Tuba is a small wild plant, whose roots contain a vegetable poison that has an extraordinary effect upon fish; and tuba fishing is one of the recognised national pastimes of the Malay Peninsula and of Sarawak. Many a great river is tuba-ed annually on so extensive a scale that at the end of the day one might well believe that it had been depleted of fish. Yet the succeeding year shows no diminution either in the size of the fish or in their numbers.

At Ahman's suggestion I sent for Pawang Duhamat, a recognised expert in all matters relating to tuba and tuba fishing. When he came he gave his opinion in favour of the Blat river as being the most suitable, in its present condition of water, for our object, and said that he had in his house, stored and ready for use, the quantity of tuba root that we should require, about ten hundredweight.

I bought the root from him, and, when he had selected an auspicious day for the fishing, issued invitations to the chiefs, and proclaimed to the district at large that on that date I should tuba the Blat river.

A few days before the appointed day Pawang Duhamat and Ahman collected four or five Malays, unpaid volunteers, and paddled away up river to make the preliminary arrangements. They took with them a few measures of rice from my store-room, but for the rest depended upon such fish as they could catch, and upon an old gun which I had lent Ahman, nominally as a protection against tigers, but really to enable him to get some jungle-fowl and imperial pigeon. Their object was to erect a barricade across the river at the 
point that Pawang Duhamat might select as the place for the tuba fishing to end. The building of this barricade was no light task, and upon its stability would depend much of the success of the day.

They were to encamp upon the river-bank while engaged upon this work, and to remain there when it was completed, to see that no harm befell it before we arrived.

Upon the day appointed a great throng of boats of all sizes collected round my landing-stage, and, with great booming of gongs, we started up-stream. We found that Ahman had completed the barricade across the river, having left only a small passage for our craft to pass through. When the last boat had squeezed past, the barricade was completely and finally closed, and, until it was opened or broken, no fish or boat could pass it to go either up-stream or down-stream. We were now in clear, shallow water, and urged by the boat-poles the boats made rapid way up the river. On either bank was great primeval forest. Late in the afternoon we reached the sandy spit which Pawang Duhamat had selected as a favourable spot for the tuba fishing to begin. By sunset we had made all our preparations for the night. The little boat in which I came, my houseboat being too unwieldy, was broad enough to hold a jungle mattress, but the majority of the men had come in light dug-outs, in which it was impossible to sleep, and they had to encamp upon the bank. Their preparations were simple: a kajang (palmleaves sewn together with rattan), four posts stuck in the ground, and a couple of boat-poles across 
them, made in a few minutes an excellent protection against the dew ; and a few handfuls of tepusleaves afforded a comfortable and fragrant matting. Three pointed sticks hammered into the ground made a tripod for the rice-pot, and what more does any man want?

At first the moon was overcast with heavy clouds that threatened rain, but the surrounding darkness only set off the cheerful brightness of the campingground. The lights of the different fireplaces fell brightly on the forms of the men, their rude lean-to's, the throng of boats, and flickered gaily on the trunks of the great solemn forest trees above and around us. Later the clouds passed away, and the glorious full moon shone upon us.

By seven o'clock all had finished their evening meal, and small woven cases of native cigarettes, and little covered bowls of silver or copper, containing betel-leaf and its accessories, were brought out and passed round. After a while old Pawang Duhamat was seen handling a short thick bludgeon. Similar bludgeons immediately made their appearance on every side, and then we all went down to the water's edge. Ten dug-outs lay a little apart from the others: cleaned and washed, stripped of everything, they were mere empty vessels. The tuba root lay in great bales on the bank. Each man picked up as much as he required, and took it to one of the empty boats. After splashing a few gallons of water into the boat, he soaked a piece of the root in the water for a moment, and then began to pound it with his bludgeon. As the root abraded, a little 
milky juice ran out, and trickled down the side of the boat into the water at its bottom. While he pounded the root, he sprinkled it from time to time with an occasional splash of water from the river. Round each of the ten boats as many Malays as could find a place collected, each bang-bang-banging away at a piece of root: those that could find a foothold on the narrow lines of the gunwales perched there happily, whilst the others stood contentedly in the river, despite its coldness. Above the din of the pounding bludgeons rose the babble of voices and laughter.

A wag of a boatman of mine began telling storiessome of them about Sir Peace of the Forest, the little mouse-deer that by his cleverness became ruler over all the other animals, and some of them about the choleric captain of a local coasting-steamer; and all told with a wealth of happy imagination and happier mimicry that convulsed his audience into apoplectic choking.

When proceedings were in full swing, Ahman suddenly pounced on a luckless youngster.

"Here is a useful man. Before his root is half pounded he throws it away. How many boat-loads of root shall we require to satisfy this spendthrift of other people's property?"

The poor youth was covered with confusion; but soon attention was turned from him by Ahman catching a man throwing a worn-out piece of root into the river, instead of carefully depositing it out of harm's way upon the bank.

"Allah! the pride of some men. Itam will not 
wait for us. He is going to tuba the river to-night on his own account, and what chance will there be for the rest of us to-morrow?"

And Itam was very properly humble.

After a while one of the men burst into a song, of which the refrain sounds somewhat as follows:-

"Deng-a-deng :-Deng—deng-deng :-Deng-a-deng !Deng-a-deng-deng :-Deng-deng-dang-

Deng-a-deng-deng :-Deng-dang-dong."

The Malays call it the "dendang" song, and to a wild catchy refrain, of which my written characters can only give a bare idea, they sing impromptu verses. When the first singer had finished a stanza, another man answered it, and then the two sang against one another, time and time about, each happy turn of a phrase or trick of a rhyme winning instant appreciation and applause from a highly critical audience, until one man, failing of a reply, admitted the other's victory and, with a laugh at his defeat, handed on the right of contest to a third party.

By the time that midnight was reached and the moon was poised overhead, the dug-outs were half filled with the milky juice of the abraded root; and as there was no sign of the abatement of the energy of the pounders or the spirit of the singers, I stole away to the bed on my boat.

At the little distance the "dendang" had a lullaby sound, and the soft moonlit streaks of the smoothly flowing water were a restful sight on which to close sleepy eyes. All round us was the great primeval forest, old beyond all knowing, and from age to age but rarely invaded by man; and from the heart of 
the forest came wafts of night odours, fragrant of rich soil, of leaf-mould, and of strong strenuous tree life-wafts only sensible to man in the hours of darkness.

When we woke the next morning the ten dug-outs lay nearly brimful of the thick milky juice of the tuba poison. A hasty meal, and then on every side fish spears were brought out. The unambitious produced a serampang, a three- or four-pronged spear which is useful for any fish up to five pounds; those more hopeful of adventure had a tempuling, a spear with a barbed detachable head to which a rope is tied. It will hold anything, and with the bigger fish it is a necessity; but, on the other hand, it misses many of the average-sized fish.

The camp was struck in a few minutes, the palmleaf coverings rolled up, the boat-poles collected, and the place that had resounded to the song and laughter of the night was abandoned.

When we were all in our sampans and prahus, Pawang Duhamat stepped on the bow of one of the tuba-laden dug-outs, and stood up amidst the silence of the throng. A fine-looking old Malay was he, erect and tall above the average height, with the high-raised cheek-bones of his race, dark expressive eyes, and sad lines round his mouth. A thin grey beard on the point of his chin added to his venerable appearance. $\mathrm{He}$ leant on his fish spear, and then uttered the following charm over the tuba water :-

"Hong ! Hak! Tina buih ipong

Batang ku tarik bulan charan

Naik segala yang bisa tuba jinul." 
When, many weeks later in the privacy of my house, he confided the words of this charm to me (for no one could catch the rapid mutter in which they were uttered), all that he could tell me of the first two lines was that they were in the language of the Jins. With the exception of jinul, which is the Jin's word for tuba, the third line is Malay, and means, "Let all that is poisonous in this tuba arise."

$\mathrm{He}$ also told me that this charm so increased the efficacy of the poison that one boat-load of the root was, if thus charmed, the equivalent of two boat-loads of uncharmed root. After a few minutes' silence, during which we waited for the poison of the root to assert itself, Pawang Duhamat splashed some of the liquid into the river, and then gave the word for the contents of eight dug-outs to be thrown overboard. The tuba juice in the remaining two boats was reserved for later use.

With one accord the multitude raised the ringing Malay war-cry, and amid shouting and excitement the liquid was flung into the river. The milky juice soon lost itself, and for a space we all kept our positions, while the vessels that had held the poison were washed and cleansed. Then Pawang Duhamat led the way down the stream. For a few hundred yards there was not a sign of a fish; everything had sped away from the first taste of the poisoned water. Then in a little eddy by the side of the river we saw a dazed fish swimming slowly in circles on the water's surface. It had had one taste of the poisoned water, and instead of fleeing down-stream on and on as the other fish had done, it had turned into some hiding- 
place to wait-under some stump, perhaps, or by the roots of an old tree that had often afforded a refuge from bigger fish or a place of safety in times of floods, but which gave no protection against the insidious tuba. A second taste of the poison and it had floated helpless to the surface.

Pawang Duhamat bade the man who paddled his dug-out to turn towards the fish, and then he slowly and deliberately speared it. He cut it in two, and repeated over it this charm:-

"Pekih! Pekah!

Ayunberdum is my bodyguard!

Jibrail is my weapon !

O Gathering of Angels at the Gate of Earth,

Rise ye up to the Gate of Earth !

O Children of the Gathering of Angels at the Gate of Sky,

Come ye down to the Gate of Sky!

Let us all be joined in a Bond of Union,

Let us all join in one Game ;

It is not that I wish to thrust aside all the doings of the Jins,

It is not that I wish to thrust aside all the doings of the Children of the Gathering of Men :

It is that I am under the Canopy of Allah !"

If there is not in this invocation, uttered in the midst of the throng that floated on the breast of the stream deep in the recesses of the boundless uninhabited forest, something that touches the imagination, let the fault be ascribed to the translator.

Pawang Duhamat threw one half of the fish on to the right bank as a propitiatory offering to the Jins, and the other half on to the left bank for the Sheitans.

When this was done, all were free to find and spear 
their fish as best they could; and, with yells from their occupants, the boats darted forward. But the race was not to the swift, for the pace was set by the stream which carries the poison; and when the first excitement had subsided, the boats glided gently and silently forward.

The next few bends of the river presented the sad sight of the day, for here were numbers of fry lying dead on the surface of the water. At the place where the tuba water is poured into the stream, not only is there, of course, enough poison to affect the whole river, but the liquid mixes equally with the surface and the bottom of the river. Later the specific gravity of the tuba water, which is considerably heavier than that of river water, asserts itself, and the poison is carried along the bottom of the river. The small fry that flee for safety to the shallows then escape unharmed; but, at first, a number of them are killed. It is the sight of these poor little dead fishes that is responsible for the general, and totally incorrect, opinion that tuba fishing kills all the fry in the river.

The poison affects different species of fish in different ways. Perches, probably through seeking the shallows with the fry, escape altogether ; the mud fish find safety in burying themselves; while the little buntal, a small fish with a peculiar power of inflating itself, floats dead to the surface at the first taste of the poison. But the great majority of the fish seek safety in flight.

Keen eyes in one boat mark, under an overhanging branch, the lips of a fish which cannot breathe the 
tainted water breaking the surface of the stream to inhale the freshness of the air. But the fish, though distressed, has not lost its senses, and before the spear can be thrust it has disappeared.

A broad brown back is seen as a temoli swims slowly down the river, and two boats dart towards it. Neck and neck they race until they are within a few yards of the fish, when the splashing of their paddles alarms it, and it dives. A hundred yards farther down the river it rises to the surface again, and the race begins anew. Gradually one boat gains on the other, and at last is some three yards ahead. As the occupant of the leading boat raises his arm to stab, the Malay in the other hurls his spear.

Under the steel of the descending spear the point of the long spear of the thrower flashes and then buries itself, quivering, fair between the shoulders of the temoli.

It is a splendid throw, and, despite their discomfiture, the occupants of the first boat join in the applause.

A few minutes later a great belida, that has been skulking under a bank, and hoping perhaps to make a dash up-stream to purer water, is transfixed and held up by an exultant Malay for all to see.

The tuba is doing its work well, and on every side we shout our compliments and congratulations to Pawang Duhamat. We shout because the Malay fully realises that a compliment, like a libel, owes much to its publication.

Some fish are half dead when seen for the first time, and therefore afford no excitement, unless a race is 
necessary; whilst other fish will keep the occupants of a dozen boats on tenterhooks for a quarter of an hour, and give all the excitement of an otter-hunt. Some fish are so affected by the poison, that it appears to be necessary for them to come to the surface to breathe. Though extremely alert, they cannot stay below the surface for more than a minute or so. When the boats surround a place where one of these fish has been marked down, the men all wait with uplifted arm for it to reappear. Perhaps some one sees its lips at the water's surface by the roots of an old tree: as he hurls his spear the fish dives, and the Malay has to disengage the barbs of the spear-head from the tree-roots with such patience as he can. Two or three minutes pass and, as the fish does not reappear, there are fears that it may have escaped, until it is seen quietly hiding under the stern of a dug-out. Before the occupant sees it, it is gone again. Eventually, after many misses, a clever thrust, delivered just as it rises to the surface, transfixes it, and amid tumultuous shouts it is lifted into a boat.

The day wears on. Bend after bend the beautiful forest-clad banks open themselves in front of us and close behind us. In each dug-out rises a heap of fish; and an occasional splash, with a lift of the light split-bamboo flooring, tells of an imprisoned monster.

The chief excitement of the day is occasioned by the shout of "Buaia." Buaia, the crocodile, as a rule, is found in Malay rivers only in tidal waters. But, be the reason what it may, not only do a certain 
number of crocodiles find their way up to the higher reaches of the rivers, but they even dare to leave for miles the safety of the water to seek a way through pathless forests. It may be that the motive is one of direct pressure: or may it be that this chill and repellent saurian is animated by the instinct of the English younger brother, and wanders forth in quest of adventures?

The crocodile is only a small one, some four feet long, and manages to escape unharmed after having caused a ripple of excitement down the length of the river by the mere terror of its dreaded name.

All day long there is nothing to break the continuity of the great virgin forest that clothes either bank. But not for a moment of the long day could one find any degree of monotony in its endless lines and masses. Though the general aspect of the forest is that of great dark-foliaged trees, every turn of the river affords a view that has something in it of individuality, and the variety in the endless succession of views is as delicately marked as their general similarity is broadly outlined. Added to the charm of the beauty of the forest is the charm of its mystery. For mile upon mile, hundreds of miles upon hundreds of miles, it extends north and south and west. All that it holds of life is hidden from our eyes under the heavy screen of foliage. Under any tree that lines the bank a tiger might be lying, or perhaps some shy naked aboriginal, armed with a blow-pipe and poisoned darts, might be peeping to see the passing throng of Malays. But however close we might be to tigers or to Semangs, we should no more see them than we should see the fish 
in the depths of the pools over which our boats were passing.

Bend after bend of the river now lay behind us. As best we might, when the excitement slackened temporarily, and the fish seemed to have all fled before the tuba, we snatched a hasty meal. When we were within a mile of Ahman's barricade, where the final scene would be enacted, Pawang Duhamat emptied into the river the two-boat loads of tuba water that he had saved in the morning, repeating the same short incantation as he did so.

Then we pressed on to the barricade. This, as I have said, extended across the river. Stout posts had been driven, a few feet apart, deep into the sandy bottom of the river. Between them was supported, from one bank to the other, a framework made of split bamboos so closely laced together with rattans that no fish could pass between the interstices. The bottom of the framework was pegged to the river bottom, and its top rose to a height of some eight feet above the surface. In addition to this framework the posts supported a light platform on which a man might stand. It was about a foot above the level of the river, and was on the up-stream side of the bamboo framework. Some three hundred yards above the barricade, on either bank, a great post with a streamer of red cloth had been erected. This marked the limit below which only the boats of chiefs might pass, and old Ahman and Pawang Duhamat stationed themselves there to see that none should intrude. The four principal chiefs of the district and I took our stand on the 
narrow gangway of the barricade, and with uplifted spears waited for the coming of the fish. The tuba water was still some way up-stream, but it was driving the fish before it.

In the press of the boats above the line marked by the red flags an occasional spear rose and fell and rose again, but in the open space immediately above the barricade all was still. Suddenly the surface of the water was broken, and a great fish launched itself at the barricade. The gleam of a bar of silver and the twinkle of falling drops, and then the fish hit the bamboo framework some four feet above the level of the river. With a mighty splattering of its tail it managed to maintain its position for a moment, and then it fell on to the platform just in time to escape the thrust of a chief's spear. While the old man was extricating his barb from the bamboo framework the fish leapt free, and, leaving only some glittering scales behind it, fell back into the river. A moment later another huge broad back showed above the surface, and we saw a fish carefully and deliberately trying to find whether, in the length and breadth of the barricade, there was not some loophole of escape. A steady hand drove the spear, and after a struggle a young chief laid the fish on the platform.

Soon the fish came in numbers, and we were thrusting and stabbing on every side, now at one as it hit the barricade, now at another in the water; now at one as it fell back on the platform; sometimes at one as it flashed through the air. While we thrust at one, another would leap up beside us, 
and before we could turn it too would fall back into the water. Beside each of us there grew up a pile of splendid fish.

One magnificent fish-a great temoli, weighing perhaps sixty pounds-twice launched itself at the barricade, and twice escaped in safety back into the water; but each time it fell back on the up-stream side, and safety from the tuba only lay in flight and access to the down-stream side.

Then, during a lull, while all were waiting, the great fish broke the surface of the water some eight feet away from the barricade, and, cleaving through the air like a broad spear-head, rose up to the top of the bamboo framework. It hit the barricade some few inches below its summit, and hung balanced for a moment. Two men thrust at it and missed it, and then the framework bent back under the great weight, and the noble fish fell into the water on the down-stream side-safe.

This was one of the last fish of the day, and before long all was over. We made our way to a sandy spit where the day's catch was exhibited. Malay women appeared on every side, bringing great earthen jars in which such fish as were not to be eaten fresh would be made into highly-flavoured, awful-scented pickles for future use. But at the meal which now awaited us it was fresh fish that we were to feast upon,--fish, fresh from the river, and held, before their scales had ceased to glisten, over the fire to grill: merely split down the middle, and impaled upon a toasting-fork of sharpened bamboo. Grilled fish eaten with rice and coarse rock-salt-nothing 
more; but nothing could be more delicious. There might perhaps be a handful of wild bird's-eye chilies, culled from the river-bank during the day, and now produced with exultation, and pounded with the rocksalt to form a red pungent paste; or there might be a lime dragged forth from the depths of a wallet to be sliced and sprinkled over a fish's richly browned back. But for the most part we have nothing but rice and salt and grilled fish-and we want nothing more. We have no curry, because it takes too long to prepare. Besides, who wants a curry to-day? There is nothing like grilling to bring out the true flavour of a fish, and nothing like rice and salt to make one appreciate that flavour.

We feel it our duty to eat of every kind of fish; partaking, sparingly perhaps, of the inferior in order to know the difference between it and the moderately good, and taking helpings of the moderately good in order to realise how sweet the best kind are. "Take some of the belida," an old chief will tell you, "and then see how succulent is the kelah."

But of all the day's strange sights the strangest sight is to see the fish fry playing and splashing for the rice grains that fall from the plates on the scene where all the great fish had been speared a short hour before. Except where it is first poured into the water, and where the poison permeates top and bottom of the river, tuba does not kill the fry. The fry, keeping to the surface, escapes the tuba, which follows the bottom.

Some years ago I was present at a tuba fishing party given by His Highness the Sultan of Pahang 
to the British Resident and the District Officers. When we were at lunch in the Sultan's boat, after a tremendous catch of fish at the barricade, His Highness pointed to the swarms of fry that surrounded the kitchen boats, and, inverting the Malay proverb, "Big fish eat little fish," said "Big fish die, but little fish eat." 


\section{A WERE-TIGER.}

Some years ago I was travelling on a somewhat delicate mission in one of the petty sultanates of the Malay Peninsula that lie to the north of the federated states administered under British protection. The state is a long narrow strip of land lying on the east coast, and is traversed by a number of rivers that run parallel to one another from their source in the main range of the peninsula to the China Sea. The area of the district watered by each of these rivers is perhaps 500 square miles, of which at least 495 are forest. At the mouth of every river a few hundred Malays collect and make a living by fishing; while, scattered up and down the stream, separated from one another by distances varying from one to five miles, are small clearings containing ten, twenty, or even fifty families, who are dependent upon an annual crop of padi and the collection of various forest products, such as rubber, gutta, and rattans. As against the rest of mankind, the Malays say that the land is theirs; but no one knows better than themselves that the real lord and master of the country is the forest. Each clearing has been hacked out of the primeval forest with infinite trouble; the period of its 
possession is marked by one continuous fight against aggression by forest seeds and creepers and weeds of every description, and when, finally, it is abandoned, it is covered within a few months by a dense and almost impenetrable scrub that will eventually grow up to become forest. My only companion was To'Kaya, an important and influential chief of one of the districts of the state, and our following consisted of a few Malay boatmen. To'Kaya was a fine specimen of a Malay of the last generation. He was some fifty years old, but time had had little apparent effect upon his wiry agile frame. He was a short man, not more than five feet four inches in height, of neat trim build, with square shoulders and small hands and feet. He had little superfluous flesh, but the curves of his arms and chest showed a muscular development considerably greater than would have been expected. His head was small and well shaped, its poorest feature being a broad and somewhat flat nose. The whole of his scalp was clean shaven, and chin and cheeks were kept free of occasional hairs by the use of tweezers. The striking feature of his face was a small, fierce, closely-cropped moustache of rather coarse bristly hairs, whose almost snowy whiteness afforded a brilliant contrast to the smoothness of his face and head, and to the rich olive-brown of his complexion. His eyes were somewhat sunken, with an expression of suffering and patience, but the crow's feet at their corners often curved into unexpected lines of humour. In every expression the old man showed the quiet dignity and self-respect of the true Malay. 
Round his waist he wore the national garment-a sarong, which is in shape like a somewhat wide sack with the bottom cut off. His coat was nearly as primitive, for it was innocent of buttons, and could only be put on and taken off by being pulled over the head. A big coloured handkerchief was tied round his forehead, with a fantastic peak carefully arranged in front. Sarong, coat, and handkerchief were all of Malay weaving and coloured with native dyes, and nothing could be more simple or more effective and becoming to the wearer.

We took boat at the mouth of one of the rivers, the Malays at first using their paddles in the tidal waters where the inflowing tide bore us swiftly past densely timbered banks, and afterwards exchanging their paddles for poles when at last a sandy bottom was reached. We poled slowly against a strong current until the river became so narrow and so shallow that farther progress by boat was difficult. Then we left the river, and struck inland at right angles to it. For a whole day we made our way along a narrow track through heavy forest, where the great trees afforded shade and coolness even at midday. At sunset we camped on a ridge that formed the watershed between the river we had left and the one for which we were making. An armful of leaves was thrown down to make a bed for each, and a deftly plaited screen of wild palm-leaves was placed over the beds to keep off the dew.

During the night at intervals "the spirits of the semambu" called to one another in a little ravine below us. The semambu is the Malacca cane of 
commerce, and the Malays imagine that each plant has a spirit. At night-time, they say, spirit calls to spirit, making inquiry as to the length of the cane between the joints: panjang? belum? "is it long? not yet?" cries a high resonant voice, throwing the accent of the question sharply on the second syllable of each word; then, after a pause, another voice is raised in a different key, and with the accent and falling intonation of the sad response, panjang, belum: "it is long, not yet."

The call is really that of an insect, but the sound is weirdly voice-like, and the vibrations of the question and reply awake a corresponding thrill in the listener.

We also heard, two or three times during the night, the trumpeting of some wild elephants that had been alarmed by meeting our tracks. The next morning we continued our journey, which lay through dense forest the whole day, and emerged at nightfall upon a little village on the bank of the river we sought. Here we requisitioned a dug-out, and the next morning started down-stream.

The pleasant easy progress of the boat, which was carried by the swift current and only required the gentlest paddling to give it steering way, was a welcome rest after the days of laborious poling and travelling. To'Kaya and I sat under a little awning made of palm-leaves sewn together, and talked the long day away, while reach after reach the bends of the river opened a gleaming way before us, and reach after reach the forest-clad banks closed in behind us. The small Malay clearings that appeared at intervals 
on the banks only accentuated the sense of the overpowering dominion and vastness of the all-encompassing forest. Its mastery held us, and our conversation for the most part turned upon its inhabitants, both animal and supernatural. Thus we came to the discussion of were-tigers, which are in the Malay Peninsula the counterpart of the were-wolves of Europe. That were-tigers exist no Malay doubts; and the popular belief is that the men from the district of Korinchi in Sumatra have the power of assuming the form of a tiger at will, and that in this guise they range the forest, hunting the wild game and occasionally killing mankind.

The Korinchi men, who are mostly pedlars of cloths, naturally resent the imputation, and contend that it is only some of the men of Chenaku, a subdistrict of Korinchi, who have this unholy power. But as the contention admits the existence of the power amongst certain of the suspected class, the Malays of the Peninsula are only strengthened in their opinion, and believe the charge to be true of all Korinchis. To'Kaya told me of a village where, for some months, the fowls had been harried by a tiger or panther, both of which are known to the Malays by the same generic term, and where one day a Korinchi man lying sick with fever in the house of the headman, who had had pity on him, had vomited quantities of undigested chickens' feathers. I, in my turn, told him a story that I had heard in the reaches near the source of the Slim river. There, in an isolated hill-padi clearing, lived a Malay, his wife, and their two children, young boys of the age 
when they learn to read the Koran. One night came a rap at the door of the house, which, like all Malay dwellings, was built upon posts some ten feet above the ground. In answer to a demand from the father as to who was at the door and what was wanted, a voice replied, "We ask for a light, our torches are extinguished, and we have still some distance to go to the house where we are expected." Now, it is well known that this is a common device of jins and evil spirits to obtain admission to a house, and one should always beware of opening the door to give a light to a stranger who pretends to be belated. Well, the two boys, while the father was questioning and crossquestioning the stranger, slipped out of the house by the ladder behind the kitchen. Excited by the visit of a stranger at such an hour, they moved silently along the ground under the bamboo flooring to peep upwards at the threshold. There, on the rung of the ladder next below the door, stood a man talking to their father; but even while he spoke a tail striped in black and yellow dropped down behind his legs, and then up and down his lower limbs ran successive ripples of change and colour. The toes became talons, the feet turned to paws, and the knee-joints, already striped with the awful black and yellow, were turning from front to back.

And all the time the human face of the creature was giving specious explanations to the questions of the master of the house. Half in fascination, half in desperation, the two boys seized the tail that dangled before them, and shouted to their father to kill the thing. But before he could reach for his spear the 
animal, now nearly all tiger, tore itself from the puny grasp of the youngsters and fled into the darkness of the forest. Though I did not tell the story as a true one, To'Kaya shook his head and said, "That was a narrow escape. But it is fitting that we should talk of were-tigers, for here in the village of Bentong which we are approaching there was a were-tiger not many years ago."

This is the story: not, it will be seen, as To'Kaya told it, but as I have reconstructed it from what he told me.

A few years ago Bentong, a village of considerable importance in a sparsely-populated district, for it consisted of some fifty houses, had suffered much from the depredations of a tiger. Scarcely a month passed without a buffalo or two being taken, and the Malays were in despair. They had tied up goats with springguns set over them, and they had made elaborate traps, like gigantic mouse-traps, baited with dogs. But the tiger would have none of them, and the Malays were beginning to talk of abandoning the village, for they depended upon the buffaloes to plough the padifields, and the possible extermination of the herd meant nothing less than utter ruin.

Such was the state of things in Bentong when late one afternoon, in drenching rain and growing darkness, an old Korinchi pedlar named Haji Brahim was hastening towards the village, where he intended to spend the night. He had a regular round through the district, in which he had been known for years, and the next day would peddle cloths and silks to the women-folk, collect his small debts, and then move on 
to the next village. The inclement weather and slippery path had made him much later than he had expected, for, like every one else in the district, he had heard of the Bentong tiger. He was making his way somewhat nervously, therefore, hoping that every turn in the narrow forest-track would disclose the village clearing, when he was panic-stricken to hear the tiger roar within a short distance of him. Shaking with fear, he ran for his life towards the village. He had not gone far before he came on a tiger-trap built at the side of the track, ready set with its bait of village cur, and with the door wide open. Struck by the idea that the timbers which would keep a tiger in would also keep one out, he dropped on his hands and knees, crawled in, and let the heavy door fall behind him. And when the tiger roared again in still closer proximity, on one occasion within a few feet of him, and continued to roar in the vicinity at intervals through. out the night, he forgave the presence of the unclean dog that cowered beside him, and blessed the thought that had led him to seek such a refuge.

When morning broke it found him stiff and shivering from the effects of the night's rain, the exposure, and the cramped position; but it found him alive, and for that he added special thanksgiving to the morning prayer of every Muhammadan believer. He discovered that from the inside of the trap he was unable to raise the heavy falling door, but remained where he was, content with the knowledge that before long some one would certainly pass along the track. In this he was notdisappointed, for soon he heard a man approaching, and shouted to him for assistance. The man looked 
round him on all sides, but failed to discover whence the voice came.

"Where are you?" he replied.

"Here! Here in the tiger-trap!"

The Malay came up and, peering into the darkness of the trap, cried, "Who are you? What is it?"

"It is I, Haji Brahim," was the answer. "I am in the tiger-trap."

The man peered yet closer, his somewhat dull wits puzzled by the strangeness of the situation, and then suddenly recognised the features of the captive. As suddenly a light struck him. "It is Haji Brahim, the Korinchi," he yelled in an access of terror. He forgot the helpless position of the inmate of the trap : he could only realise one fact, that the tiger, which for so long had been the pest of Bentong, was a weretiger; and without another word he turned and ran down the track as though he ran for his life.

The' boom of the mosque-drum soon reverberated through the village, and in answer to its summons every able-bodied Malay thronged to the house of the chief, Raja Alang. The man who had given the alarm told his story, and then, after due deliberation and consultation, the men proceeded to the tiger-trap. The raja led the way, and behind him crowded the Malays, each armed with a spear, and with a belt full of krises and daggers. As they left the cultivated area and entered the forest they strung out into single line upon the narrow track, again massing in thick array behind the raja when they reached the trap. Raja Alang stepped up to the door and demanded of the prisoner- 
"What is the name of this work?"

The old man's heart sank at the tone of the stern inquiry. During the long weary vigil of the night it had not occurred to him to connect his nationality with the fact of his entering the trap: the villager's alarm had been a shock to him, but he had persuaded himself that it was the mere temporary panic of an ignorant clown. But he now saw that he was on his trial.

"Let me out," he pleaded. "Let me out, and I will explain everything."

"That cannot be," replied the raja. "First you must explain how you came to be in this trap."

"Yes," agreed the voices in the background, "for who would release a tiger when once it is caught?"

"How came you here? Was it not you whom we heard roaring last night?" demanded the raja.

"No, raja, no," answered the old pedlar ; "the tiger, which is always here, roared close to me last night, and it was to save my life that I ran into this trap."

"How can any one believe such a story?" murmured the crowd.

"The sole of your foot on the crown of my head, raja; have not you and all these men known me for many years? Am I not an old man and feeble, and could I do such a thing as this that you think of me?"

"But who ever heard of an honest man in a tigertrap?" reiterated with dull persistency the voices behind the raja. 
"The tracks will prove the truth of what I say," cried the pedlar.

The justice of the contention appealed to all, and the ground was carefully examined. But the crowd had obliterated the footprints round the trap, and all that could be seen were the tiger's tracks following a wild-game path to its junction with the main forest path, and then losing themselves in the trampled ground around the trap.

The inspection was carried out thoroughly and impartially, and its result, which of course tended to confirm the suspicions of the Malays, was communicated to the trembling captive.

"But I can prove that I left the village of Siputeh yesterday afternoon to come to Bentong. Every one saw me there," wept the old man.

"That may be true," retorted some one in the crowd with relentless logic, "but it is of last night that we talk. The tiger was here last night, and you are in the tiger-trap this morning."

The pedlar, who throughout had been on his hands and knees, the only position of which the cramped space of the trap would permit, seeing the futility of argument, turned his face up to the judges who stood massed in front of the trap and tried through his tears to recognise them.

He called to the village imaum, and offered to swear on the Koran of the mosque in any form of oath that might be imposed that his story was true. But though the Malays are, as a rule, in favour of the ordeal by oath, they felt at once that there was an obvious objection to its use in this case. The question 
which they had to decide was whether their captive was an ordinary Malay like themselves, or that awful horror, a were-tiger. It was plain that a creature so unnatural as that they imagined their prisoner to be would not hesitate to forswear itself in order to attain its liberty: not only then would the oath fail in its effect, but their mosque and Koran would have been polluted by the presence and touch of the unclean thing. When this last resource failed him the poor old man cried to those who had known him longest and best, and begged for his life for pity's sake. He promised to do anything that was asked of him, and, if necessary, to leave the country for ever. But the Malays did not dare to let themselves be influenced by any thoughts of pity or compassion. They had to decide a question upon which their herds, their crops, and their very lives depended, and that question was put to them with Malay terseness and directness by the raja.

"If we open the trap-door," he said, turning to the men who leant upon their spears behind him, "and let this that we have here now go loose, what is our position?"

What was their position? One must realise how the little village was isolated in the midst of a vast forest, how exposed the inhabitants were to any attack from it, how powerless to retaliate upon any man-eating or cattle-eating tiger, which had such easy access and such safe retreat, and how sick with helpless misery they must have felt at the mere idea that they were at the mercy of something that was partly tiger, partly demon. It is easy to imagine 
their fierce exultation at the thought of having trapped so awful a creature.

The raja repeated his question.

In answer a Malay, whose chief wealth lay in his diminishing herd of buffaloes, stood forth.

"Who of us has not lost one or more of his buffaloes? Who does not know that these Korinchis can turn themselves into tigers? Did we not all hear the tiger roar last night? Have we not got his tracks here? And here, where the tracks lead up to the trap, have we not, by the grace of Allah, got the Korinchi trapped? What more?"

“What more?" said old To'Kaya, turning to me. At the sign from the raja one of the men stepped up to the trap, and, thrusting through the open bars of the woodwork, drove his spear through the old man's side.

For a moment I was silent with horror, and then said, "Pity on an old man to die in such a manner!"

"What pity does a tiger show?" retorted To'Kaya; "and what pity can it expect? Was it not clearly proved that this man was a were-tiger? It was not that he was unjustly or unfairly tried. The men of Bentong had known Haji Brahim for many years, and against him, as a man, they had no ill-feeling. The raja-Raja Alang, whom we shall see in the village if we stop the boat and call in - is both mild and just. Could he have decided otherwise?

"If a woman is accused of sin, or a man of murder, and evidence not half so strong as that in this case 
is advanced against them in the justice halls of the states under British rule,-nay, even in the Great Court-House of Singapore,-does not the judge convict them?"

I made an expostulation, and was painfully aware that I was begging the question. To'Kaya politely, but firmly, pointed this out, and I then attacked the evidence, saying that it was merely circumstantial.

To'Kaya bowed and said, "That may be; but have not men been hanged on slighter evidence?"

I could not think of a suitable reply : and it must be remembered that I was on a somewhat delicate mission in a state of which To'Kaya was one of the principal chiefs. There was, therefore, silence for a space as our little boat broke the sparkle of the river. We were now passing the village: the banks were covered with green turf cropped close by buffaloes, a few of whom-animals that perhaps had often seen the tiger which poor Haji Brahim had met -raised their heads to stare at us. Farther back from the river was a grove of coco-nut-palms, whose slender heads and graceful curves were outlined against the blue sky; and at their feet, dotted at intervals, were the Malay houses, which are built of bamboo and plaited bertam palm-fronds, and whose colour is that of ripe dead leaves. A woman was pounding rice with a pestle worked by her foot, and in the river a number of children were playing and splashing; but the men were for the most part in their houses seeking a refuge from the heat of the day. Then suddenly a little dug - out shot forth from the bank to cross the river. One man 
poled, another steered with a paddle, and in the centre sat a fine-looking old Malay.

"It is Raja Alang," said To'Kaya.

We stopped for a while to exchange the greetings and the courtesies due to, and expected from, our various ranks. Then we parted, and at the next bend of the river the great forest swept down again to the bank on either side, shutting us off from the view of aught else, and telling us that the little village of Bentong now lay behind us. 


\section{CROCODILE SHOOTING.}

THE vast dense forest that covers the length and breadth of the Malay Peninsula generally changes its character before it reaches the coast-line. In places, it is true, one may find a rocky headland covered with heavy timber running out to sea until the waves break at its feet; but for the most part, on the east coast the forest is cut off from the sea by an open foreshore of rank wind-swept grass, between which and a shallow sandy beach grows a narrow fringe of casuarina trees, through which the sea-wind whispers, sighs, and murmurs day and night; while on the west coast, where the land falls to the sea level, a mangrove forest growing on alluvial mud takes the place of the trees of the interior.

On part of the Perak coast the mangrove forest is intersected by channels formed by joint actions of the rise and fall of the tide and of the currents of the inland streams. The effect of these channels is to cut the forest up into numerous islands of varying size, and a launch can make its journey by these back ways from end to end of the forest without being seen from the sea. In the old days before British protection, many were the exciting 
games of hide-and-seek played up and down these byways between the Chinese boats that carried the tin of the alluvial fields of Larut and the pirate prahus of the Malays.

The channels vary in width from a hundred to three hundred yards: at high tide one sees nothing on either bank but the mangrove-trees growing out of the water and occasional patches of nipah palms. At low tide the mangroves are left high and dry above the expanse of a slimy foreshore of evilsmelling mud. One notices that a line, that might have been drawn with a ruler, runs along the foot of the row of mangroves, and marks the high-water limit below which the leaves of the trees cannot live.

Above this line all is green, below it there is nothing but bare trunk. On the mud the crocodiles that infest the channels come out to bask when the tide is low.

Some months ago my tracker Manap and I were in the mangrove swamps of Larut trying to shoot a tiger that had been taking off the Chinese woodcutters on the coast. As we were returning to my launch at sunrise, after one of many fruitless night-long vigils in a mosquito-infested forest, it occurred to me to take advantage of the low tide and to paddle along the banks of the backwaters and inlets of the mangrove forest in order to pick up a crocodile or two. We left the launch to follow us at a discreet distance, and set off in a little dug-out canoe. The tide was running out fast, and long stretches of bare mud were exposed.

In the distance these flat expanses glistened in the 
morning sun like molten gold; but when seen close at hand, on either side, they resolved into a horrible blue-brown slimy mass.

Crabs of weird shapes and colours thronged the flats. Great ugly green crabs crept sluggishly over the mangrove roots, or climbed, with the appearance of painful movement, up the slime-covered snags and dead branches that jutted up abruptly above the level of the mud. With jerky efforts hermit-crabs dragged along their whelk-shell homes, and upon any alarm withdrew into the farthest recesses of their shells, which fell over backwards with horrible deathlike suddenness, and which then lay until the danger was past, as apparently tenantless as any of the empty shells that were scattered over the surface of the mud. Brown crabs scuttled towards their holes, and then, having made safe their line of retreat, stared with beady, expressionless eyes at the passing boat.

In strong contrast with these ungainly varieties, and with the surrounding of the mangrove swamps, were the little crabs : some of the brightest vermilion, others of the most perfect turquoise.

One tiny creature-a miniature in purest enamel -which had found a delicacy, plied two claws, enormous in proportion to its body, to convey infinitesimal morsels to an invisible mouth; and the claws worked alternately with the speed and clicking regularity of knitting-needles. Never was greed more prettily served. Pugnacious little creatures were they too; and each stood by its hole and waved a claw in the air on the alert for love or war.

We slowly paddled along with the ebbing tide, 
and soon disturbed a small crocodile-a youngster some four feet long. It had been hidden from sight by a dip in the bank, and we were upon it before it knew its danger. Its efforts to reach the water and safety were frantic. All its four legs clawed madly and splutteringly at the yielding mud, and its tail swung wildly from side to side as if to help it on its way. But, for all its ungainly appearance, it covered the ground at an extraordinary pace. The first bullet struck the bank just below it, and plastered it with driven splashes of mud; the second hit it fairly behind the shoulder just as it reached the water, and turned it over on its back. The head and body disappeared under water, and only the tail remained on the bank: a hind-leg waved convulsively in the air. "Mampus!" cried Manap-a contemptuous expression, of which "dead as mutton" is a fair rendering; and he paddled on slowly and with the deliberation that befitted a man who was going to pick up something barely worth the shooting. But "mampus" the crocodile was not, for, as we came up, the leg that had appealed to high heaven assumed a more natural position, and with a desperate effort the animal righted itself and managed to slide down into the muddy stream. Manap dug his paddle deep into the water, and put all the strength of his broad back into his stroke. There is no harm in thinking little of your game when you have brought it to bag, but if a man can spare any effort to make the game his when success is as yet uncertain, then either the game or the man is worth very little. As the dug-out shot 
up to the spot where the stirred-up mud marked the course taken by the wounded animal, Manap groped in the shallow water to find it with his paddle. He touched it once, but another dying effort enabled it to wriggle into deeper water where the paddle could not touch bottom. We had therefore to leave it, and after marking the spot with a pole paddled on again.

There were birds on every side: kingfishers of several species, some as big as jackdaws (one of them cursed with a maniac laugh), the smallest a purple gem, even smaller and more resplendent than the brilliantly-coloured bird of the English rivers. On the mud were padi-birds-a species of crane, the perfect and absolute whiteness of whose plumage was in as strong contrast with the sombre background as the blue of the tiny crabs. With bowed neck and abstracted mien, a marabout stork took long slow strides in search of incautious fish. Brown Brahminy kites wheeled in circles overhead. Then, in our silent approach, we disturbed a sea-eagle: sitting in a mangrove-tree on the water's-edge, it allowed us to approach within a few yards before it deigned to fly. As it launched itself forth from the tree it dropped down a foot or two before its powerful pinions had sufficient spread to bear the weight of the heavy body. Then it flapped slowly in front of us over the surface of the mud-banks. Suddenly, as if to show that it was not afraid of us, it let drop two enormous taloned legs and seized a luckless fish; crooked claws and curved beak met, and without a break in the flight the captive was 
swallowed. In a dead tree, standing white and gaunt against the blue sky, two other sea-eagles wrangled and screamed in discordant tones. At the water'sedge sandpipers tripped with dainty feet along the mud, and rose to take short flights as we approached too close. Their call "kĕ-dî-dî-kě-dî-dî" (whence they get their Malay name) was the same as that of the English sandpiper, and the clear fresh notes were reminiscent of a cooler clime and a softer scene. Green pigeons-some of the most lovely birds that fly-fluttered from tree to tree in search of fruit; and, unseen in a mangrove-tree, an imperial woodpigeon called to its mate. No thin "coo" like that of the English bird was his note, but a deep "boom" that resounded far through the forest.

Before long we saw a crocodile floating in the stream. It was close to the edge of the mud, probably making up its mind to crawl up the bank, and taking a look round before it did so. Only the tip of its snout and its eyes appeared above the surface, but the distance between these three points showed it to be a big one.

The slanting rays of the sun shone on it, and we could see the outline of its body in the water. It was probably some sixteen or seventeen feet long; but it had not grown to that length without learning wisdom, and, as it saw us, it gently sank out of sight. There was no hurry, no alarm or excitement. It merely subsided, and let the water rise over it and hide it. In such fashion might the submarine boat of an inventor's dreams sink below the surface of the water. And when the crocodile had gone there was 
not a ripple anywhere to show the place where it had been.

A couple of hundred yards farther on we marked a crocodile stretched in sleep on the mud. At this distance it was peculiarly inconspicuous, despite the serrated outline of its back and tail. Branches of trees, nipah palm-leaves, with wreckage and detritus of all sorts, are always scattered about the mud-flats, and it is difficult to say whether they or the crocodile succeed the better in their mimicry of one another. Time after time the broad back and jagged fronds of a nipah leaf will make one tighten the grasp on the rifle, and I well remember that the first time an excited Malay pointed out a crocodile to me I could see nothing but an old log. We drifted slowly towards the sleeping crocodile, and though it is not, I admit, a high form of sport, still it was exciting, for one could not tell when the animal would wake. It might only be half asleep, or not even asleep at all, and might at any moment make a dash for the water. When a crocodile does awake to realise its danger, there is such a rush and such a swirl, and the flying mud is so much the colour of the animal, that to put a bullet through its heart or head cannot but be more a matter of luck than skill. Every yard that brings the boat closer to the animal of course increases the danger of its waking; and added to the thrill of the lessening distance is the difficulty of deciding whether to take one's shot while yet one may or whether to try and get a little closer, and thus, if the animal does not first take alarm, make certain of it. Slowly and silently we drifted on until 
we were within twenty yards of the crocodile. Its whole side was then exposed, and I got an easy shot at its heart. I fired, and the animal did not move. At the moment that the bullet struck it, the jaws opened to their full extent, showing every pointed tooth in the serried rank that filled the hideous mouth, remained at their widest gape for a fraction of a second, and then closed with a snap like that of a springing rat-trap. There was not another movement of the body, but the brute lay stone-dead. Had any particle of life remained in it, it would have struggled to the water; but this snapping of the jaws, which is an involuntary muscular effort, is an infallible sign that the animal has been killed on the spot. Manap paddled to the water's-edge, struggled nearly waist-deep through the semi-liquid mud towards the brute, and, slipping a rattan round its body, tied it to a pole, which he stuck in the mud. It was a brute some ten feet long, but heavy for its length, and capable of taking off a man with ease. We signalled to the launch, which followed about a quarter of a mile behind us, to pick up the carcass as soon as we had passed on, and continued to paddle slowly down the tide. The next crocodile that we saw had apparently not yet disposed itself for its siesta, for before we approached within range it started up, whirled round, and dashed into the water. Farther on we saw another crocodile floating high in the water, with its head and body above the surface. We approached to within thirty yards before it moved. It then began slowly to subside in the same manner as the one that we had seen before. 
I fired at the diminishing target, and in a second transformed the phlegmatic saurian into a raging monster. In fury, surprise, and pain it lashed the water with its powerful tail, turning and twisting its body until the churned up water hid it from view. I fired my second barrel into the turmoil of spray and water, and the brute plunged below the surface. As soon as it had disappeared from sight, Manap's quick eyes discerned on the mud-flats the track by which the crocodile had just come down to the water.

"See," he cried, "it has not been basking; there is its wallow.

"Have you not seen a crocodile's wallow?" he asked me as he paddled on with long easy strokes, letting the tide do its full share of the work. "This is how he makes it. When the tide is at its full he comes up over the water-covered bank, and lies down on the mud close by the mangrove-trees. $\mathrm{He}$ twists and turns himself in the ooze until he has hollowed out a shallow pit, in which he lies. Then the tide turns to run out, and the mud and silt carried down by the stream settle in the wallow and on the crocodile's back and round his sides, until, by the time that the retreating tide has left the mud-flats bare, a thick layer of mud covers the crocodile, and nothing is seen to break the level expanse of ooze. The crocodile's nostrils and his eyes are, however, just above the level of the mud, though the keenest eye could not detect them. Thus he lies concealed until a family of monkeys comes chattering, playing, and scrambling over the mud to look for crabs or shellfish. 
"If one of them happens to come too close to the hidden watcher there is an upheaval of the mud, and, bap! the monkey is in the crocodile's jaws; and for all its screams and all its companions' cries it is carried off towards the water, to be devoured at leisure. Sometimes it is not a monkey but a man that is taken."

This is unfortunately only too true, and I well remember hearing at an official inquiry a Malay's horribly vivid description of his companion's death in this manner. They had been cutting nipah palmleaves together, and were loading their canoe with the fronds that they had collected, when a crocodile made a dash out of a wallow at one of the men and seized him above the knee. Neither man had a knife in his hand, and all that Awang, the wretched man who had been seized, could do was to throw both his arms round a tree and attempt to hold on. The other man, Saleh, ran to fetch his knife, which he had left in his boat, but even as he turned to run Awang had been torn from the tree and carried towards the water. Twice again did Awang momentarily check the brute's course by seizing and holding on to a tree or branch, but each time the weight and strength of the crocodile wrenched him from his support, and before Saleh returned with his knife Awang had been torn from the last tree on the river-bank, and was carried screaming to his death.

"But it is not every one," said Manap continuing his story, "who is aware that both crocodiles and tigers are forbidden to kill mankind, and that every time one of them kills a man it breaks one of the 
great laws imposed by Nabi Sleman [King Solomon] upon the animals. Every animal knows what it may do and what it may not do. The deer may live on the forest foliage and grass; the tigers may kill the deer; the various kinds of fish have their peculiar food; the crocodiles may feed on the fish and on such four-footed animals as chance may bring in their way: but no animal may wantonly attack mankind. That is the first law of Nabi Sleman; and if any animal kills a man Nabi Sleman forthwith drives it out of his fold. Thenceforth it lives apart from its fellows, an outcast and an accursed thing.

"When, therefore, a crocodile has killed a man, it tries to evade the punishment of its offence. It buries the body in the mud, and then after three days floats to the surface with it, pretending that it has just found it. It calls out over the water-

" 'It was not I, O Sun!

Not I, O Moon!

Not I, O Stars !

Bear witness all that it was not I,

Not I, that killed this man :

The Water killed him.'

And this is partly true, for the crocodile kills a man by drowning him. Then as the sun and moon and stars hold their peace, the crocodile thinks that it has freed itself of guilt, and sinks again to the riverbottom to devour the body at its leisure."

"The water killed him," Manap murmured two or three times to himself; and any one who has experience of the hair-splitting quibbles in which Muhammadan jurisconsults delight, will understand 
his appreciation, even relish, of the ingenuity of the imaginary appeal.

It was nearly the ebb-tide, and the channel grew narrow. Small fry leapt out of the water in terror at our approach, and now and again some large fish surged past between our canoe and the bank, its broad back driving a curling wave before it. To see the size and swiftness and silent strength of these great fishes made it a joy to think of the feel of a salmon-rod bending to the weight of one of them.

Playing and feeding near the surface of the water was a shoal of extraordinary small fish with long pointed snouts like those of the English garfish. But the fishes were not confined to the water,-they were crawling all over the mud-banks in every direction. Look at this fish, the ikan blachak, whose pectoral fins appears to have developed into jointed legs: it walks sturdily and determinedly over the mud, with its dorsal fin erect from the back of its neck to the base of its tail; and very imposing it looks to any fish that has not attained the dignity of its six inches. This panoply is intended to strike terror into beholders; but the ikan blachak knows its limitations, and the kites that wheel overhead will not be intimidated by any dorsal fin however stiff: so when the little fish stops, it sinks its fin and lies as close and as flat as it can to the mud its colour resembles. But should any other blachak come straying too close, at once it leaps up and with open mouth stands ready to fight if the intruder will not retreat. When thus excited it erects not only the dorsal fin, but the smaller fins that run down the black to the tip 
of the tail. Another extraordinary occupant of the flats is the ikan tembalcul: it lies on the mud like a narrow wedge of wood, with a length of about ten inches and a base of about two inches. The base of the wedge is the tembakul's head, and on the top of this square cut head is a pair of gigantic goggle eyes which stare at the world in blank surprise. It has short, powerful, bandy-legged fins with which it " hunches" itself forward over the mud. If, however, it is frightened or excited, a sideways stroke of its powerful tail sends it in flying leaps on its way. It swims in the water, too, in a weird manner, with its misshapen head and monstrous eyes high above the surface. It moves slowly and deliberately, but if startled rushes forward with more than half of its body out of water, and then suddenly bobs its head under the surface and disappears from view.

"Quick, quick, fire."

A crocodile we had not seen was rushing down the bank some twenty-five yards ahead of us. I fired, and the first bullet broke its spine and knocked it on to its side, but only stopped it for a second. It quickly righted itself, and with its two fore-feet continued to claw its way towards the water. The second bullet hit it in the shoulder, but did not stop it. By the time that I had reloaded the canoe had dashed up alongside the crocodile, whose dying struggles had brought it to within a few feet of the water. With marvellous quickness and dexterity Manap dropped his paddle, picked up a rope noose and slipped it over the crocodile's head. The brute was now half in the 
stream, and though it was to all intents dead it continued blindly to struggle towards the water. It made no effort to bite or to use its powerful tail, its one idea being to reach its natural element. "Take the paddle and strike it on the body. Don't fire." I dropped the rifle and hit the brute over the body and head until the struggles ceased, and, save for muscular contractions that rippled over its skin, it lay still.

It was a small brute, between six and seven feet long, and leaving it for the launch to pick up we paddled on. The next crocodile we saw was a little creature, not more than two feet long, that was learning to bask like its elders. Both my bullets flew over its back, and it escaped in safety.

"Do you see the patch of lalang grass by the point in front of us? Last year I found a crocodile's nest there: three-and-sixty eggs there were in it, and the clerk at the police station gave me ten cents apiece for them. Six dollars and thirty cents I got, but one does not find a nest every day. You do not know how a crocodile makes its nest? The mother selects a spot, open to the sun, on some dry sandy soil; often, as in the case of yonder nest, it is in a patch of lalang grass, often in the piai fern. She collects grass and dry fern in her mouth, and heaps them up until she has formed a pile as broad as three men can stretch from finger-tip to finger-tip, and in height midway between a man's knee and his hip. In this nest she lays fifty or sixty eggs, and covers them over with dry grass. She then makes two wallows by the nest, one on the side by the rising sun, the other towards the setting sun, and prepares 
to guard the nest against all possible enemies. Of these the worst is he who ought to give her most assistance: the male crocodile not only does not help her in collecting the grass and making the two wallows, but if not repelled by her will destroy the nest and eat the eggs. A tiger, too, loves crocodiles' eggs as he does turtles' eggs, and against him also the mother crocodile has continually to be on her guard. She sometimes will even face a man, barking and showing her teeth at him like a savage dog. ${ }^{1}$ She allows the sun to hatch out the eggs, as the Chinese do with ducks' eggs. Ah, she is very clever! as the Malays say, she has 'a long mind'; for should the day be cloudy and the sun's power be weak, she removes the covering of grass from the eggs, and at night-time, or when the rain falls, she replaces it. And if it is a hot day, not only are the eggs covered, but with her tail she sprinkles water from the wallows over the eggs. Yes, truly, she has a very 'long mind.' And the reason that she makes her wallows to eastward and to westward of the nest is in order that she may be able to interpose her body, if the day should be too hot, between the nest and the rays of the morning sun and of the afternoon sun. No, I myself have not seen all this, but I have seen many nests with their wallows, and what I have said as to the rest is what men who know about these things have told to me. And they

1 Is it not possible that the Dragon killed by St George was a crocodile that was thus defending her nest? Marco Polo gives an excellent account of the crocodiles of Southern China, and calls them dracones. 
say, furthermore, that when the eggs are hatched out all the little animals that run towards the water become buaia, the crocodile, whilst those that run towards the land become biaua, the iguana. But I do not believe that: it is a story we tell our children just as our fathers told it to us."

"Ha! listen to that."

A magnificent sea-eagle, white and grey, and resplendent in the sun, sitting on the topmost branch of a dead tree, where all might see him, had uttered two clear high notes. His ordinary call is like the mewing of a cat, but these two notes, "Hoo" "Hoo," rang out like a bugle-call.

"That means that at the river-mouth the tide has turned, and that now it is bunga pasang - 'the flower of the rising tide.' The sea-eagle is the king of all the birds in the forest, and he tells them all of the turn of the tide. With the rising tide the fish will come in from the sea, and the crocodiles will soon wake up and return to the water to seek their food. But there on the bank is one still asleep."

It was an animal some eight feet long, and it lay sound asleep with that ludicrously amiable smile at the corners of its mouth that is far more characteristic of a crocodile than are any tears. It is impossible to imagine tears in such an eye: a lifeless snaky yellow, with a narrow black slit down its centre, and devoid of every feeling but that of a bitter frozen hatred of every living creature. When the eyes are closed one can see in the 
animal's smile a trace of the creature that was once the happy innocent plaything of the Prophet's daughter. But when the eyelids open the only expression is that of eternal rancour and eternal resentment of her blighting curse. ${ }^{1}$

The sleeping crocodile allowed us to approach within easy distance, and I was able to kill it on the spot. We did not see another for some time, and then I only got a difficult shot, which I missed. The tide was now running in fast, and in more than one place there were some tracks to show where a crocodile had returned to the water.

It was time to stop, and in answer to a signal the launch steamed up alongside and took us on board. We had done fairly well, and the three crocodiles represented a total length of twenty-four feet. The Government pays a reward of twentyfive cents a foot, and as this was Manap's perquisite, the morning's work meant six dollars to him, or about the cost of the living of himself and his family for a month.

While lunch was being prepared I stood in the bows of the launch and took in all that I could of the scene I have attempted to describe: the colours of the water, of the mud, and of the mangroves; the varied multitude of the birds, the fishes, and the crabs that crowded the foreground. In a few minutes we came to a bend of the stream and the sea lay in front of us, a broad expanse of blue, with waves all laughing in the sun and twinkling

1 The Malay story of the creation of the first crocodile is told on page 67. 
into golden dimples; the breath of the south-west monsoon blew in fresh and salt from over Sumatra and the ocean beyond, and the little launch with her propeller racing at full speed left the narrow discoloured waters of the mangrove swamps and breasted the incoming tide and freshening breeze, and headed for the open sea. 


\section{APPENDIX I.}

\section{THE PAWANG.}

When a man, and more especially when a nation, is converted, it is not a question of the exchange of one religion for another. The new belief forms a stratum that covers, more or less deeply, the old one. The teachers of the new beliefs refer, with pity or contempt, to the convert's old beliefs as his superstitions-something, they say, that stands upon his religion; and thereby go as far wrong as it is possible to do, inasmuch as the truth, which they fail to see or refuse to admit, is that the things which they term a superstition are really a substratum.

When a nation accepts a third religion, the three strata of beliefs may sometimes be discerned; and of this formation, if I may so call it, an excellent example is found in the Malays of the Malay Peninsula. Until perhaps six or seven hundred years ago they were natureand spirit-worshippers, holding beliefs very similar to those of the Dyaks of Borneo at the present day. Then a wave of Hinduism swept down from India over Sumatra and Java. It reached the Malay Peninsula, but with such greatly diminished force that its traces there are but faintly discernible; whereas it has left its mark deepiy and permanently in Java, and still survives in 
the islands of Bali and Lombok on the Javanese coast. A few centuries later a far greater wave of religion came surging down from India over the same course: Muhammadanism, which had invaded India from the North - West in the eleventh century, reached Java, Sumatra, and the Malay Peninsula about the fifteenth century.

The Malays of the Peninsula became ready converts, and are now without an exception followers of the Prophet - decidedly unorthodox in many ways, it is true, but unshakable in their adherence to what they consider to be the essentials of their religion; recognising the claim of the "Law of the Custom," the Hukum Adat, the traditions of many centuries of paganism and Hinduism, on the one hand, and on the other hand the often conflicting claim of the "Law of the Prophet," the Hukum Shara, their more recently acquired code; and always ready to make a compromise between them. In certain parts of the Malay Peninsula the pre-Muhammadan customary laws of debt, land tenure, and inheritance have prevailed over the Muhammadan code, and have recently in some instances been perpetuated by judicial decisions and by statutes.

It is often said that the Malay of the Peninsula is a bad Muhammadan, because he has retained so mueh of his pre-Muhammadan beliefs. The truth more really is that he is an imperfect Muhammadan: he certainly is not an indifferent one, for even his severest critics will admit that he would die rather than willingly do what he believes to be forbidden. If he is told that his habitual omission to say the five daily prayers, for instance, will ensure his eternal damnation, he will be greatly distressed to hear it; but he will probably contend that this is not the law as he knows it, and thence proceed to try to persuade his critic, as he has persuaded himself, that a man should be judged not by the law, but by the law as he knows it.

Of the old pagan religion the pawang, or sorcerer, is 
the priest. He still survives in nearly every village in the Malay Peninsula, and is the counterpart of the manang of Borneo and shaman of the Mongolian tribes. Although a sorcerer, he is, like every one else in the community, a Muhammadan; and he defends himself, his practices, and beliefs from the attacks of the orthodox followers of the Prophet by claiming for his craft the sanction of the adat, the immemorial custom of the country.

The following beliefs are represented by the pawangs, and survive to-day from the old pagan times. A belief

(i) in certain great and powerful spirits called the Jin Tanah and Jin Laut, the "Spirits of the Earth" and the "Spirits of the Sea";

(ii) in innumerable lesser spirits of the mountains, rivers, and forests, and even of particular rocks, rapids, and trees;

(iii) in familiar spirits created by the pawangs, and ordered to obey their commands;

(iv) in the animistic properties of plants and trees (of this idea, the best known example is the annual ceremony of tending the soul of the rice crops);

(v) in were-tigers ;

(vi) in invisible folk;

(vii) in death-avenging influences;

(viii) in a spectral huntsman;

(ix) in innumerable spooks, goblins, bogeys, and weird apparitions of various kinds.

There still survives a pagan tradition of the creation of the world by the first pawang and a bird. This most extraordinary story is not considered in any way incompatible with the Muhammadan tradition of the creation, with which the Malays are of course perfectly familiar.

During the period of Hinduism the pawangs borrowed largely from the Hindu mythology. The very word for the spells or charms which they repeat to propitiate the spirits is pure Sanskrit (mantra); and in the mantras there still survive to this day the names of Siva, Vishnu, Rama, 
Ganesha, Hanuman, and Arjuna. There are memories of heavenly creatures like the dewa, dewata, chandra, and bidadari; of demons like the Indian bhuts, which the Malays call Bota; of ogres (gergasi), and of giants (raksasa). There has been a tendency-which was very natural perhaps - to degrade the Hindu gods to the level of mere forest spirits.

When Muhammadanism swept Hinduism away before it, the pawang turned eagerly to the new religion to borrow what he could. The only spirits lower than the angels of which the Koran admits the existence are the Genii (Jin) and Fairies (Peri), some of whom are said to be believers and some unbelievers. They are imagined to be created of pure fire, to be of both sexes, to propagate their species, and to eat and drink. They were at once accepted and introduced into the mantras. So also were the archangels Jibrail (Gabriel), Mikail (Michael), Azrael, and Israfil. One is not surprised to find their names; but one may own to a feeling of awe at finding in the mouth of a pawang in the Malay Peninsula the name of Azazel, the pre-Mosaic demon of the wilderness, to whom the scapegoats of Leviticus xvi. were sent as an offering. ${ }^{1}$

Actuated, perhaps, by a desire to show that their old beliefs were in no way incompatible with their new religion, the pawangs also freely introduced the Muhammadan Prophets into their mantras. Nabi Noh (Noah, who is supposed to have charge of all the plants and trees), Nabi Sleman (Solomon, who rules over all the animals), Nabi Musa (Moses), and Nabi Muhammad himself, are frequently invoked; and the mantras often begin with the words, "In the name of Allah, the All-Compassionate and All-Merciful," and end with the words, "There is no God but Allah, and Muhammad is the Prophet of Allah."

But this is not the whole of the borrowings of the pawangs. The Siamese, who are the neighbours of the

${ }^{1}$ It is only right to say that D'Herbelot gives another account of Azazel in his 'Bibliothèque Orientale.' 
Malays on the north of the Peninsula, were, like the Malays, at first nature- and spirit-worshippers. When they were converted to Buddhism their old beliefs found in the new religion an attitude so gently tolerant, and even so kindly disposed, that the old beliefs continued to flourish to an extent impossible under Muhammad's stern creed of "There is no God but Allah." The Siamese are more skilled than the Malays in the use of charms, spells, and herbs; and the Malays so readily admit the superiority, that in many a Malay village one may find an old Siamese man who has established himself there as the local pawang. Neither the Malays nor the Siamese, the Muhammadans nor the Buddhists, seem to consider the position in any way remarkable: more or less unconsciously they recognise the fact that they meet on common ground in the beliefs that both nations shared before their religions took them along different paths. As an example of the extent to which the Malay pawangs are indebted to the Siamese, I may refer to an article in Journal No. 45 of the Royal Asiatic Society (Straits Branch), to which I have contributed an account of the mantras used by the Malays in catching wild elephants. The charms have been in use for many generations, and the Malays have little knowledge of their origin other than that there is a tradition that it is Siamese. The language is certainly not Malay, and is either some exceedingly corrupt form of Siamese, or else some tongue that is no longer known in the Peninsula. The influence of the Siamese pawangs is also seen in the frequent reference in the mantras to the Maha Rishi, the Great Sages of Buddhism.

Such, then, are the sources from which the pawang has derived his present knowledge of charms, spells, and medicines. His services are requisitioned at every birth and death (not at a wedding, a social contract of comparatively modern origin and distinctly religious aspect, where the kathis and imaums will not brook his interference), at every sowing and reaping of the rice-crop, 
and at every accident or illness. The opening of a tinmine, the construction of a dam, or the erection of a fishing-stake, always call for his attendance.

The functions of a pawang are roughly divided into spirit-raising and spirit-propitiation. Spirit-raising, the coercion of spirits, is known by the Malays as ber-hantu. It is the pure undiluted shamanism of the Mongolians; and upon the exercise of the power every Malay looks with considerable dread, and even the least orthodox shakes his head when it is mentioned. It is seldom attempted, and every year is becoming more rare. I have only twice attended a séance,- - once on the occasion described in "The Pinjih Rhino," and once when a chief was about to perform the long and dangerous pilgrimage to Mecca (its use on such an occasion shows how deeply rooted the belief is), and his relatives were anxious to know what the future might have in store for him. On both occasions I particularly noticed that the pawang and the audience, for no other reason than that they knew that they were about to do something which the law of Muhammad held to be wrong, made a special point of commencing the proceedings with a recitation from the Koran. Spirit-propitiation is considered a far less serious matter, the reason perhaps being that the offering of small gifts, such as eggs, limes, or a bowl of rice, and the repetition of mantras, is a simple and apparently innocuous thing, very different from participation in the wild scenes where in successive ravings, ecstasies, and collapses the pawangs are possessed of demons.

The collection of mantras given in the article "A DeerDrive" is a fair example of a pawang's lore. A similar set, with appropriate ceremonies and due offerings, would be used at the opening of a new clearing in the forest or any similar enterprise. In the case of sickness, the pawang adds a potion or poultice, or perhaps a pill of paper upon which weird figures have been traced. Often he will insist upon the person or persons interested keeping some peculiar observances which generally take the form of 
something not to be done rather than something to be done. This is known as pantang, and corresponds to the well known tapu or taboo.

The Malays believe that the power lies in the mantra itself, not in the man that repeats it. The Hindus have the same idea, but amongst them the use of the mantras is confined to the Brahmins: they have a proverb-

"The earth is subject to the gods :

The gods are subject to the mantras:

The mantras are subject to the Brahmins :

Therefore the earth is subject to the Brahmins."

The Malays admit of no caste restrictions; and the pawang from whom I learned the mantras set forth in the article "Tuba Fishing" assured me that, when I had committed them to memory, they would be as effectual in my mouth as they were in his own.

The pawangs (like the manangs of Borneo) are not a hereditary class, though, as one would expect, a son often follows in his father's footsteps in the same way that in England a gamekeeper or a sexton succeeds his father. Any man who has shown a little aptitude may learn from a pawang all that he has to teach, if the application for tuition is made with due deference and in proper form. There are certain (often many) observances to be kept, and some services to be rendered; and there is a recognised fee, - so many lengths of cloth, so many measures of rice, and so many pieces of silver. The fact that the pawang's craft does not necessarily descend from father to son is interesting, for among most of the Mongolian tribes the shaman priesthood is strictly hereditary. There, in fact, so much is the profession confined to certain families that the shaman priests pretend to derive their power from the spirits of their deceased ancestors. Such an idea is unknown to the Malay.

When a man's skill has made him famous, the word pawang is prefixed to his name as a title; and even in official documents, such as the grants issued by the Land 
Offices, one may find such names as Pawang Duhamat or Pawang Glam.

Only a small percentage of the pawangs attempt spiritraising. The majority confine themselves to the mantras, offerings, and medicaments. They specialise very considerably. One man will devote himself to the lore regarding the spirits and influences connected with tin-mines; another to those attendant on rubber-collecting or camphor-hunting expeditions; while a third, in whose special care the rice-fields or fishing-stakes may be, will probably be entirely ignorant of the charms and spells used by the other two men.

The pawangs are dying out. It is not that the civilisation of British rule exercises a direct influence upon the native belief in this respect, but that this civilisation is making the inhabitant of the Peninsula more of a Muhammadan and less of a Malay. The more he learns of his religion the more he realises how impossible is the compromise that has been allowed to exist for the last four or five centuries between his pre-Muhammadan beliefs and the precepts of the Prophet.

He has only to open his Koran, and turn to the seventysecond chapter, which is entitled the Genii, to find a severe condemnation of those who, in fear of any spirits or in the hope of propitiating them or of appeasing their wrath, make any application or petition to such spirits instead of making their prayer to Allah, who alone is God, and to whom all things in heaven and earth are subject. No hair-splitting, no quibble of the wiliest of pawangs, can evade this uncompromising denunciation; and the alien Muhammadans, whom the rapid development of the Malay Peninsula has brought into the country within the last ten or fifteen years, are not slow to press home the charge of apostasy against the pawang. The Javanese and Sumatra-men, earnest, narrow-minded followers of the law, the Indians, who are even more strict, and the Arabs, who are the sternest of bigots, have no sympathy for the pawang; they have nothing in their blood that 
cries out for the old aboriginal beliefs : and in the mosques and village deliberations, at all times and at all seasons, they denounce him and all his works. The Malays, too, perform the pilgrimage to Mecca in larger numbers every year, and each man upon his return, when he has donned the hajis turban and frock, feels constrained to conform to a stricter observance of the faith, and therefore to frown upon the poor pawang as savouring unduly of heathendom.

It is the alien Muhammadan immigration, not British civilisation, that is the enemy of the pawang; and as the pawangs of the present generation, who still hold their position by their personal influence, die off, there will, except in the more remote districts and villages, probably be but few men of the younger generation to take their place. 


\section{A P P E N D IX II.}

\section{THE MANTRAS.}

\section{The Forest. Page 11.}

As salam aleikom,

Aku datang ini bersahabat sehaja, Sehaja na' menchari hal Kahidupan, Janganlah angkau mengaru-ngaru ku, Dan anak istri ku,

Dan rumah tangga ku,

Dan segala kampong laman ku, Aku yang na' tumpang bersahabat ini, Mintalah selamat pulang balik.

\section{Page 11.}

Hei! Salam aleikom,

Kita na' tumpang tambat

Pada sa' rimbun daun

Sri bergenta sa' panjang lampei.

\section{A Deer Drive. Page 54.}

As salam aleikon, Beribu ka bumi, Bapa ka langit, 
Sudara ka ayer,

Aku na' tumpang tambat

Pada sa' rimbun daun

Sri bergenta sa' panjang lampei.

\section{Page 55.}

Ah gana! Mah gana!

Turun gana angkau, naik gana aku;

Turun jinggi angkau, naik jinggi aku ;

Jinggi sa' ratus sembilan puloh;

Sah pindahlah angkau,

$\mathrm{Ka}$ cherang tiada berburong,

Ka laut tiada berikan,

Ka padang tiada berrumput,

Sah pindahlah angkau dengan kuasa Allah.

\section{Page 56.}

Hei! Salam aleikom,

Serjang bumi sa' kilat lalu,

Kalau angkau lalu ujong,

Ka lautan yang besar,

Nempoh pangkal, ka gunong api yang besar,

Angkau ikut sa' denai raia,

Permatang yang panjang,

Sinilah tampat angkau ikut,

Balik ka kandang nabi slêman.

\section{Page 57.}

Hei! Salam aleikom,

Sri bergenta sa' panjang lampei,

Lalu dua, angkau pegang dua,

Lalu sa', sa' angkau pegang,

Lalu besar, besar angkau pegang,

Lalu kechil, kechil angkau pegang, 
Aku ta' tahu-kan jahat, tahu kan baik, Putus, aku ta' chakap mengganti Hilang, aku ta' chakap menchari.

\section{Page 58.}

Hei! tejah jantan di ujong sidin aku, $\mathrm{Ru}$ tunggal di pangkal sidin aku, Tinggallah mu, aku na' pergi menghambat Segala raiat nabi slêman.

\section{Page 60.}

Si panji lela nama anjing aku, Si panji ladang nama anjing aku, Angkau hambatlah raiat nabi slêman Yang sa' kilat lalu, serjang bumi, Yang bersubang mas, Yang berchaping mas, Yang diluar kandang nabi slêman.

\section{Page 60.}

Tu- u- u- u- u-

Telekul lam telekul, Sanggana dewerna, Raja Una punya pegang. Tu- u- u- u-.

\section{Page 63.}

Ah bahdi, Mah bahdi, Aku tahu asal angkau bahdi, Sa' kling mas tuli, Sa' pancha mas buta. Demaga Adam asal angkau bahdi. 
Aku tahu k' asal angkau membuang bahdi Aku tahu k' asal angkau membuang genaling, Gempa chahia membuang angkau bahdi, Gempah pakoh membuang angkau genaling.

Hei! Malik Zabaniah!

Bukakan pintu yang sulit, Aku endah membuang seklian bahdi, Bukakan tampat yang lepas, $\mathrm{Na}$ ' membuang seklian genaling.

Jangan bri tuntut daua kapada aku, Kapada rumah dan tangga aku, Kapada kawan dan teman aku, Jangan angkau tuntut daua Kapada rodong sain aku Jangan angkau tuntut daua Kapada anjing pemburu aku, Kalau angkau tuntut daua Angkau neraka kapada Allah Angkau neraka kapada Raja Yang Brahi.

Crocodile Catching. Page 73.

Sang Raga, Sang Ragai

Sambutlah perkiriman Siti Fatimah.

Kalau Angkau ta' makan, Mati di pengkalan ayer, Mati di pengkalan tulang, Mati di pengkalan darah.

Tuba Fishing. Page 255.

Pekih, pekah.

Korinchi nama yang bersi, Ayun berdum hulubalang ku, Jibrail akan senjata ku, 
Hei! sidang maleikat di pintu bumi,

Naik angkau ka pintu bumi.

Hei ! anak sidang maleikat di pintu langit,

Turun angkau ka pintu langit.

Mari kita sa-rêkat-êkat,

Mari kita sa' permainan,

Aku tiada akan tolak segala perbuatan jin,

Aku tadia akan tolak segala perbuatan sheitan,

Aku tiada akan tolak segala perbuatan anak sidang manusia,

Karana aku berpaiong Allah.

Crocodile Shooting. Page 289.

Hei! matahari, bukanlah aku,

Bukanlah aku, bulan

Bukanlah aku, bintang,

Saksi-lah kamu yang bukanlah aku,

Bukanlah aku yang membunoh orang ini, Ayer yang membunoh.

THE END. 
(

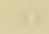

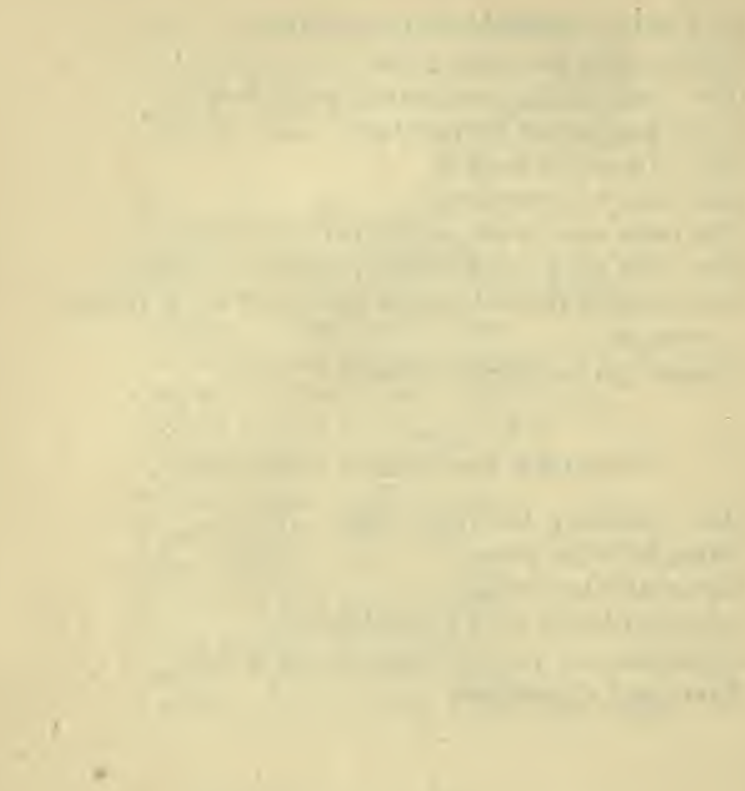




\section{A Catalogue \\ of \\ Messrs William Blackwood \& Sons' \\ Publications}

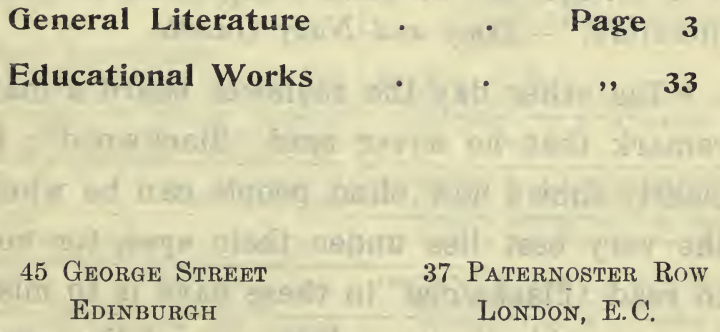

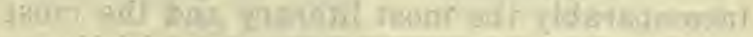




\section{BLACKWOOD'S}

\section{MIAGALIN显。}

"I wonder whether readers are appreciating as they should the extraordinary life and vigour with which 'Blackwood's Magazine' is being conducted. It is like no other Magazine in the world in its range of subject and interest." -Sir William Robertson Nicoll in "The British Weekly.'

"We are never disappointed when we open BLACKWOOD. 'Maga' has a distinction, character, and note of its own. Grave or gay, it is always full of good things and of good literature."-Army and Navy Gazette.

"The other day the reviewer heard a man remark that he never read 'Blackwood'; it clearly shows how blind people can be when the very best lies under their eyes, for not to read 'Blackwood' in these days is to miss incomparably the most literary and the most interesting of the monthly magazines." -

\section{The Times of India.}

Subscribers both at home and abroad can have 'Blackwood's Magazine' sent by post monthly from the Publishing Office, 45 George Street, Edinburgh, for 30s. yearly. 


\section{GENERAL LITERATURE.}

ACCOUNTANTS' MAgAzINE, THE. Monthly, except September and October. 6d. net.

\section{ACTA SANCTORUM HIBERNIAE;} Ex Codice Salmanticensi. Nunc primum integre edita opera CAROLI DE SMEDT et JOSEPHI DE BACKer, e Soc. Jesu, Hagiographorum Bollandianorum; Auctore et Sumptus Largiente JoANnE Patricio Marchione Bothas. In One handsome 4 to Volume, bound in half roxburghe, £2, 2 s. ; in paper cover, 31s. 6d.

\section{ADAMSON, PROFESSOR.}

THE DEVELOPMENT OF MODERN PHILOSOPHY. With other Lectures and Essays. By ROBERT ADAMSON, LL.D., late Professor of Logic in the University of Glasgow. Edited by Professor W. R. SORLEY, University of Cambridge. In 2 vols. deny 8vo, 18s. net.

THE DEVELOPMENT OF MODERN PHILOSOPHY. Edited by Professor W. R. SORLEY, University of Cambridge. Demy 8vo, 10s. 6d. net.

THE DEVELOPMENT OF GREEK PHILOSOPHY. Edited by Professor SORLEY and R. P. HARDIE, M.A. Demy 8 vo, 10s. 6d. net.

FICHTE. (Philosophical Classics for English Readers.) [Fcap. 8vo, 1s. net.

AIKMAN, DR C. M.

MANURES AND THE PRINCIPLES OF MANURING. By C. M. Aikman, D.Sc., F.R.S.E., \&c., formerly Professor of Chemistry, Glasgow Veterinary College, and Examiner in Chemistry, University of Glasgow, \&c. Second Impression. Crown 8vo, 6s, 6d.

FARMYARD MANURE: ITS NATURE, Composition, and Treatment. Crown 8vo, 1s. 6d.
ALISON, SIR ARCHIBALD, BART.

HISTORY OF EUROPE. BY Sir ARCHiBALD Alison, Bart., D.C.L.

1. From the Commencement of the French Revolution to THE Battle oF WATERLOO.

People's Edition, 13 vols. crown 8vo, £2, 11s.

2. Continuation to the Accession of LOUIS NAPOLEON.

Library Edition, 8 vols. 8vo, $£ 6,7$ s. 6 d.

People's Edition, 8 vols. crown $8 \mathrm{vo}$, $34 \mathrm{~s}$.

ALLEN, J. W.

THE PLACE OF HISTORY IN EDU. CATION. By J. W. Alien. Crown 8 vo, 5s. net.

ALMOND, HELY HUTCHINSON. CHRIST THE PROTESTANT, AND OTHER SERMONS. By HELY HUTCHINSON ALMONd. Crown 8vo, $5 \mathrm{~s}$.

ANCIENT CLASSICS FOR ENGLISH READERS. Edited by Rev. W. LuCas Collins, M.A. Price 1s. each net. For List of Vols. see p. 32.

ANDERSON, REV. GEORGE, B.D.

THE SCOTTISH PASTOR. A Manual of Pastoral Theology. By Rev. Georar Anderson, B.D., Minister of Renfrew, Lecturer on Pastoral Theology under the General Assembly of the Church of Scotland. Crown 8vo, 2s. 6d. net.

ANDERSON, J. MAITLAND.

ST ANDREWS UNIVERSITY MAT. RICULATION ROLL. By J. MAITlaND ANDerson. Demy 8vo, 18s. net.

A PLAIN WOMAN.

pOOR NELLie. By A Plain Woman. Crown 8vo, 3s. 6 d. 
ARMYTAGE, A. J. GREEN = . MAIDS OF HONOUR. By A. J, Green-Armytage. Crown 8vo, 5s.

ATKINSON, MABEL.

LOCAL GOVERNMENT IN SCOT. LAND, By Mabel Atrinson, M.A. Demy 8vo, 5s. net.

AYTOUN, PROFESSOR.

LAYS OF THE SCOTTISH CAVALIERS, AND OTHER POEMS. By W. Edmondstoune Artoun, D.C.L., Professor of Rhetoric and BellesLettres in the University of Edinburgh. New Edition. Feap. 8vo, 3s. 6d. Cheap Edition. Cloth, 1s. 3d. Paper covers, 1s.

AN ILLUSTRATED EDITION OF THE LAYS OF THE SCOTTISH CAVALIERS. From designs by Sir NozL Paton. Small 4to, 10s. 6d.

BADEN-POWELL, MAJOR B. BALLOONING AS'A SPORT. By Major B. BADEN-Pow ELL. With Illustrations. Crown 8 vo, 3s. 6 d. net.

BAIRD, J. G. A.

THE PRIVATE LETTERS OF THE MARQUESS OF DALHOUSIE. Edited by J. G. A. BAIRD. Second Impression. With Portraits and Illustrations. Demy $8 v 0,15 \mathrm{~s}$. net.

BAIRD LECTURES.

(See under Flint, Mitchell, Nicol, and Robertson.)

BANKS, D. C.

THE ETHICS OF WORK AND WEALTH. By D. C. Banks. Crown 8vo, 5s. net.

BARBOUR, G. F., D.Phil.

SOME PHILOSOPHICAL ASPECTS OF CHRISTIAN ETHICS. By G. F. Barbour, D.Phil. Crown 8vo.

BARBOUR, R. W.

THOUGHTS FROM THE WRITINGS OF R. W. BARBOUR. Post $8 v o$, limp leather, 2s. 6d. net.

"BARFLEUR."

YAVAL POLICY. A PLEA FOR THE STUDY OF WAR. BY "BARFleur." Demy 8vo, 2s. 6d. net.

BARRETT, C. R. B.

HISTORY OF THE 13th HUSSARS. By C. R. B. BARretT. Small 4 to. Illustrated.

BARRINGTON, MICHAEL.

THE KING'S FOOL. By Michael BaRRINGTON. Crcwn 8vo, 6s.

THE REMINISCENCES OF SIR BARRINGTON BEAUMONT, BART. A Novel. Crown 8vo, 6 s.
BARTLETT, E. ASHMEAD -

THE PASSING OF THE SHEREEFIAN EMPIRE. By E. AshMEAD-BartLETT. Illustrated. Deiny 8 vo, 15 s. net.

BELLESHEIM, ALPHONS, D.D. HISTORY OF THE CATHOLIC CHURCH OF SCOTLAND. From the Introduction of Christianity to the Present Day. By Alphons BellesHEIM, D.D., Canon of Aix-la-Chapelle. Translated, with Notes and Additions, by Sir D. Oswald Hunter Blair, Bart., O.S. B., Monk of Fort Augustus. Cheap Edition. Complete in 4 vols. demy $8 v o$, with Maps. Price 21s. net.

\section{BESANT, SIR WALTER.}

RABELAIS. (Foreign Classics for English Readers.) By Sir Walter Besant. Feap. 8vo, 1s. net.

\section{BLACK, KENNETH MACLEOD.}

THE SCOTS CHURCHES IN ENG. LAND. By KenNeTh Macleod Black. Crown 8vo, 5s. net.

\section{BLACKBURN, DOUGLAS.}

A BURGHER QUIXOTE. By DOUgLAS Blackborn, Author of 'Prinsloo of Prinsloosdorp.' Second Impression. With Frontispiece. Crown 8vo, 6s.

RICHARD HARTLEY : PROSPECTOR. Crown 8vo, 6s.

BLACKIE, JOHN STUART.

NOTES OF A LIFE. By JoHN STUART Blackie. Edited by his Nephew, A. Stodart Walker. Crown $8 v 0,6$ s. net. THE LETTERS OF JOHN STUART BLACKIE TO HIS WIFE. With a few earlier ones to his Parents. Selected and edited by his Nephew, A. Stodart WALKkr. Second Impression. Demy 8vo, 12s. 6d. net.

\section{BLACKWOOD.}

BLACKWOOD'S MAGAZINE. Monthly, 2s. 6d. Post free for one year, 30s.

ANNALS OF A PUBLISHING HOUSE. William BLACKWOOD AND His SONS; Their Magazine and Friends. By Mrs Oliphant. With Four Portraits. Third Edition. Demy 8vo. Vols. I. and II., £2, 2s. Large Paper Edition, $£ 4$, 4s. net.

ANNALS OF A PUBLISHING HOUSE. Vol. III. JoHN BlackwOod. By his Daingter, Mrs Blackwood Porter. With Two Portraits and View of Strath. tyrum. Demy 8vo, 21s. Large Paper Edition, \&2, 2s. net. 
BLACKWOOD. - contd.

TALES FROM BLACKWOOD. First Series. Price 1s. each in Paper Cover.

They may also be had bound in 12 vols., cloth, $18 \mathrm{~s}$. Half calf, richly gilt, $30 \mathrm{~s}$.

Or the 12 vols. in 6 , roxburghe, $21 \mathrm{~s}$. Half red mornceo, $28 \mathrm{~s}$.

TALES FROM BLACKWOOD. Second Series. Complete in Twenty-four Shilling Parts. Handsomely bound in 12 vols., cloth, 30s. In leather back, roxburghe style, $37 \mathrm{~s} .6 \mathrm{~d}$. Half calf, gilt, 52s. 6d. Half morocco, 55s.

TALES FROM BLACKWOOD. Third Series. Complete in Twelve Shilling Parts. Handsomely bound in 6 vols., cloth, 15s.; and in 12 vols., cloth, 18s. The 6 vols. in roxburghe, 21s. Half calf, 25s. Half morocco, 28s.

TRAVEL, ADVENTURE, AND SPORT. From 'Blackwood's Magazine.' Uniform with 'Tales from Blackwood.' In Twelve Parts, each price 1s. Handsomely bound in 6 vols., cloth, $15 \mathrm{~s}$. And in half calf, 25s.

NEW EDUCATIONAL SERIES. See separate Educational Catalogue.

NEW UNIFORM SERIES OF NOVELS (Copyright).

Crown 8vo, cloth. Price 3s. 6d. each.

Now ready :-

Wenderholme. By P. G. Hamerton.

The Story of Margrédel. By $D$. Storrar Meldrum.

A Sensitive Plant. By E. D. Gerard. LADY LEE'S Widowhood. By General Sir E. B. Hamley.

Katie Stewart, and other Stories. By Mrs Oliphant.

VALENTINE AND HIS Brother. By the Same.

Sons and Daughters. By the Same.

Marmorne. By P. G. Hamerton.

Reata. By E. D. Gerard.

Beggar my Neighbotr. By the Same.

The Waters of Hercules. By the Same.

Fair to See. By L. W. M. Lockhart. Mine is Thine. By the Same.

Doubles and Quits. By the Same.

Piccadilly. By Laurence Oliphant. With Illustrations.

LADY BABY. By D. Gerard.

Poor Nellie. By A Plain Woman.

STANDARD NOVELS. Uniform in size and binding. Each complete in one Volume.
BLACKWOOD-contd.

FLORIN SERIES. Illustrated Boards. Bound in Cloth, 2s. 6d.

The Cruise of the Midae. By the Same.

Cyril Thornton. By Captain Hainilton.

The Provost, \&c. By John Galt.

Sir ANDREW Wri.IE. By the Same.

Reginald Daltox. By J. G. Lockhart.

Pen Owen. By Dean Hook.

AdAM Blair. By J. G. Lockhart.

LADY LeE'S WIDOWHOOd. By General Sir E. B. Hamley.

The Perpetual Curate. By Mrs Oliphant.

JoHn ! A Love Story. By the Same.

SHILLING SERIES, Illustrated Cover. Bound in Cloth, 1s. 6d.

The Rector, and The Doctor's Family. By Mrs Oliphant.

The Life of Mansie WaUch. By D. M. Moir.

Peningular Scenes and Sketches. By F. Hardman.

Sir Frizzle Pumpkin, Nights at Mess, \&c.

VALERIUS: A Roman Story. By J. G. Lockhart.

BON GAULTIER'S BOOK OF BALLADS. Eighteenth Edition, with Autobiographical Introduction by Sir THEODORE MARTIN, K.C.B. With Illustrations by Doyle, Leech, and Crowquill. Small 4to, 5s. net.

BOWHILL, MAJOR J. H.

QUESTIONS AND ANSWERS IN THE THEORY AND PRACTICE OF MILITARY TOPOGRAPHY. By Major J. H. Bowhill. Crown $8 \mathrm{vo}, 4 \mathrm{~s}$. $6 \mathrm{~d}$. net. Portfolio containing 34 working plans and diagrams, 3s. 6d. net.

BRACKENBURY, GENERAL SIR HENRY, G.C.B.

SOME MEMORIES OF MY SPARE TIME, 1856-1855. By General the Right Hon. Sir Henry Brackenbury, G.C.B. With Portrait. Crown 8vo, 5s. net.

BREADALBANE, THE MARCHION= ESS OF.

THE HIGH TOPS OF BLACK MOUNT.

By the Marchioness of Breadalbane. Second Impression. With Illustrations from Photographs by Olive Mackenzie. Short demy, 6s. net.

\section{BRIDGES, PHILIPPA.}

THE GREEN WAVE OF DESTINY. Bx Philippa Bridges. Crown 8vo, 6s. 
BRODRIBB, W. J.

DEMOSTHENES. (Ancient Classics for English Readers.) By W. J. BrodribB. Fcap. 8vo, 1s. net.

\section{BRUCE, MAJOR CLARENCE DAL-} RYMPLE.

IN THE FOOTSTEPS OF MARCO POLO. Being the Account of a Journey Overland from Simla to Pekin. By Major Clarence Dalrymple Bruce. With Illustrations. Demy 8 vo, 21s. net.

BUCHAN, JOHN.

THE WATCHER BY THE THRESHOLD, AND OTHER TALES. By JOHN Buchan. Second Impression. Crown $8 \mathrm{vo}, 6 \mathrm{~s}$.

A LODGE IN THE WILDERNESS. Second Impression. Short demy $8 \mathrm{vo}, 6 \mathrm{~s}$.

SOME EIGHTEENTH CENTURY BYWAYS, AND OTHER ESSAYS. Demy 8vo, 7s. 6d. net.

BURBIDGE, F. W.

DOMESTIO FLORICULTURE, WINDOW GARDENING, AND FLORAL DECORATIONS. Being Practical Directions for the Propagation, Culture, and Arrangement of Plants and Flowers as Domestic Ornaments. By F. W. BuRBIDGE. Second Edition. Crown 8vo, with numerous Illustrations, $7 \mathrm{~s} .6 \mathrm{~d}$.

BURTON, JOHN HILL, D.C.L.

THE HISTORY OF SCOTLAND. From Agricola's Invasion to the Extinction of the last Jacobite Insurrection. By John Hill Burton, D.C.L., Historiographer-Royal for Scotland. Cheaper Edition. In 8 vols. crown 8 vo, $2 \mathrm{~s}$. 6 d. net each.

THE BOOK-HUNTER. A New Edition, with specially designed Title-page and Cover by Joseph Brown. Printed on antique laid paper. Post 8vo, 3s. 6d.

BUTE, JOHN, MARQUESS OF.

THE ROMAN BREVIARY. Reformed by Order of the Holy CEcumenical Council of Trent; Published by Order of Pope St Pius V.; and revised by Clement VIII. and Úrban VIII.; together with the Offices since granted. Translated out of Latin into English by John, Marquess of Bute, K.T. New Edition, Revised and Enlarged. In 4 vols. crown $8 \mathrm{vo}, 42 \mathrm{~s}$. net. In 1 vol. crown 4to, 63s. net.

THE ALTUS OF ST COLUMBA. With a Prose Paraphrase and Notes. By John, Marquess of Bute, K.T. In paper cover, 2s. $6 \mathrm{~d}$.
BUTE. JOHN, MAROUESS OF.

SERMONES, FRAT KIS ADA, ORDINIS PRAMONSTRATENSIS, \&c. Twenty. eight Discourses of Adam Scotus of Whithorn, hitherto unpublished; to which is added a Collection of Notes by the same, illustrative of the rule of St Augustine. Edited, at the desire of the late Marquess of Bute, K.T., LL.D., \&c., by WALTER DE GRAY BIRCH, LL.D., F.S.A., of the British Museum, \&c. Royal 8vo, 25s. net.

CATALOGUE OF A COLLECTION OF ORIGINAL MSS. formerly belonging to the Holy Office of the Inquisition in the Canary Islands. Prepared under the direction of the late Marquess of Bute, K.T., LL.D., by WALTER DE Gray Birch, LL.D., F.S.A. 2 vols. royal $8 \mathrm{vo}, £ 3,3$ s. net.

BUTE, MACPHAIL, and LONS= DALE.

THE ARMS OF THE ROYAL AND PARLIAMENTARY BURGHS OF SCOTLAND. By John, Marquess of BUte, K.T., J. R. N. MACPHAIL, and H. W. Lonsdale. With 131 Engravings on wood, and 11 other Illustrations. Crown 4 to, $£ 2,2$ s. net.

BUTE, STEVENSON, and LONSDALE.

THE ARMS OF THE BARONIAL AND POLICE BURGHS OF SCOTLAND. By John, Marquess of BuTr, K.T., J. H. Stevenson, and H. W. LoNSDALE. With numerous Inlustrations. Crown 4to, £2, 2s. net.

CAIRD, EDWARD, LL.D.

HEGEL. (Philosophical Classics for English Readers.) By Edward CaIRD, LL.D. Feap. 8vo, 1s. net.

CAIRD, PRINCIPAL.

SPINOZA. (Philosophical Classics for English Readers.) By Principal CAIRD, Fcap. 8vo, 1s. net.

CALDWELL, PROFESSOR WILLIAM.

SCHOPENHAUER'S SYSTEM IN ITS PHILOSOPHICAL SIGNIFICANCE (the Shaw Fellowship Lectures, 1893). By Professor William CaldWELL, D.Sc., M'Gill University, Montreal. Demy 8vo, 10s. 6d. net.

CALLWELL, COL. C. E., C.B.

THE EFFECT OF MARITIME COMMAND ON LAND CAMPAIGNS SINCE WATERLOO. By Col. C. E. Callwell, C.B. With Plans. Post 8 vo, 6s. net. 
CALLWELL, COL. C. E., C.B.-contd. TACTICS UF TO-DAY. Second Edition. Crown 8vo, 2s. 6d. net.

MILITARY OPERATIONS AND MARITIME PREPONDERANCE : THEIR RELATIONS AND INTERDEPENDENCE. Demy 8vo, 15s. net.

THE TACTICS OF HOME DEFENCE. Crown 8 vo, 3s. 6d. net.

\section{CANDLER, EDMUND.}

THE MANTLE OF THE EAST. By EDMUMD CANDLER. Illustrated. Crown 8 vo, 6s. net.

THE GENERAI: PLAN. Crown 8vo,6s.

CAREY, WYMOND.

"No 101." Third Impression. By WrMOND CAREY. Crown 8vo, 6s.

CARLYLE, R. W., C.I.E., and A. J., M.A.

A HISTORY OF MEDIEVAL POLITICAL THEORY IN THE WEST. By R. W. Carlyle, C.I.E., Balliol College, Oxford; and A. J. CARLYLE, M.A., Chaplain and Lecturer (late Fellow) of University College, Oxford. In 3 vols. demy 8 vo. Vol. I. - A History of Political Theory from the Roman Lawyers of the Second Century to the Political Writers of the Ninth. By a. J. Carlyle. 15s. net. Vol. II.Demy 8 vo, 15s. net.

\section{"CHASSEUR."}

A STUDY OF THE RUSSO-JAPANESE WAR. By "CHASSEUR." Crown 8vo, 6s. net.

CHESNEY, SIR GEORGE, K.C.B.

THE DILEMMA. By General Sir Georae Chesnex, K.C.B. A New Edition. Crown 8vo, 2s.

CHRISTIE, REV. GEORGE, B.D.

THE INFI,UENCE OF LATTERS ON THE SCOTTISH REFORMATIUN. By Rev. George Christie, B.D. Crown 8 vo, 6s. net.

\section{CHURCH, REV. A.}

OVID. (Ancient Classics for English Readers.) By Rev, A. Church. Fcap. $8 \mathrm{vo}, 1$ s. net.

CHURCH, REV. A., and BRODRIBB, W. J.

PLINY. (Ancient Classics for English Readers.) By Rev. A. CHURCH and W. J. Brodribb, Fcap. 8 vo, 1s. net.

\section{CHURCH SERVICE SOCIETY.}

A BOOK OF COMMUN ORDER : BEING FORMS OF WORSHIP ISSUED BY the Church Service Society. Seventh Edition, carefully revised. In $1^{\circ}$ vol. crown 8vo, cloth, 3s. 6d. ; French morocco, 5s. Also in 2 vols. crown $8 \mathrm{vo}$, cloth, 4s.; French morocco, 6s. 6d.

DAILY OFFICES FOR MORNING AND EVENING PRAYER THROUGHOUT THE WEEK. CrOWn 8 vo, 3s. 6 d.

ORDER OF DIVINE SERVICE FOR CHILDREN. Issued by the Church Service Society. With Scottish Hymnal. cloth, 3 d.

CLARKE, MAJOR SEYMOUR.

THE BOYDS OF PENKILL AND TROCHRIG: THEIR ANCESTORS AND DESCENDANTS. By Major Seymour Clarke, Queen's Own Cameron Highlanders. 4to. 5s. net.

CLIFFORD, SIR HUGH, K.C.M.G.

SALEH : A SEQUEL. By Sir HUGH Clifford, K.C.M.G. Crown 8vo, 6s.

\section{CLODD, EDWARD.}

THOMAS HENRY HUXLEY. "MOdern English Writers." By EDwarD Clodd. Crown 8vo, 2s. 6d.

\section{CLOUSTON, J. STORER.}

THE LUNATIC AT $I+R G E$. By J. Storer Clouston. Ninth Impression. Crown 8vo, fs. Cheap Edition, 1s. net.

COUNT BUNKER: Being a sequel to 'The Lunatic at Large.' Third Impression. Crown 8 vo, $6 \mathrm{~s}$.

THE ADVENTURES OF M. D'HARICOT. Third Impression. Crown 8vo, $6 \mathrm{~s}$. Cheap Edition, $6 \mathrm{~d}$.

OUR LADY'S INN. Crown 8vo, $6 \mathrm{~s}$.

GARMISCATH. Crown 8vo, 6s.

COLEBROOKE, HELEN.

WINGED DREAMS. BY HELEN COLEBROOKE. Crown $8 \mathrm{vo}, 6 \mathrm{~s}$.

COLLINS, c. W.

SAINT SIMON. (Foreign Classics for English Readers.) By C. W. Collins. Fcap. 8vo, 1s. net.

SOPHOCLES. (Ancient Classies for English Resders.) Fcap. Svo, 1s, net.

PLATO. (Aneient Classies for English Readers.) Fcap. 8vo, 1s. net.

COLLINS, W. E. W.

IAEAVES FROM THE DIARY OF A COUNTRY CRICKETER. BY W. E. W. Collins. Crown 8 vo, 6 s.

COLLINS, REV. W. LUCAS.

BUTLER. (Philosophical Classics for English Readers.) By Rev. W. L. Col.Lins. Fcap. 8vo, 1s. net.

MONTAIGNE. (Foreign Classies for English Readers.) Fcap. 8vo, 1s. net. 
COLLINS, REV. W. LUCAS.

LA FONTAINE, AND OTHER FRENCH FABULISTS. (Foreign Classics for English Readers.) Fcap. 8vo, is. net.

HOMER, ILIAD - HOMER, ODYSSEYVIRGII-CICERO -ARISTTOPHANES -PLAUTUS AND TERENCE-LUCIAN - LIVY - THUCYDIDES. (Ancient Classics for English Readers.) Fcap. 8vo, 1s. net.

COMBE, MRS KENNETH.

CELIA KIRKHAM'S SON. By Mrs KenNeth Combe. Second Impression. Crown 8vo, 6s.

SEEKERS ALI. Crown 8vo, $6 \mathrm{~s}$.

COMPTON-BURNETT, I.

DOLORES. By I. COMPTON-BURNETT. Crown $8 v 0,6 \mathrm{~s}$.

CONRAD, JOSEPH.

LORD JIM: A TALE. By JOSEPH CONRAD, Author of 'The Nigger of the Narcissus,' 'An Outcast of the Islands,' 'Tales of Unrest,' \&c. Fourth Impression. Crown $8 \mathrm{vo}, 6 \mathrm{~s}$.

YOUTH : A NARRATIVE; AND TWO OTHER Stories. Third Impression. Crown $8 \mathrm{vo}, 6 \mathrm{~s}$.

\section{COOPER, REV. PROFESSOR.}

IITURGY OF 1637, COMMONI,Y CALIED LAUD'S LITURGY. Edited by the Rev. Professor Cooper, D.D., Glasgow. Crown 8vo, 7s. 6d. net.

COPLESTON, BISHOP.

AESCHYLUS. (Ancient Classics for English Readers.) By Bishop Copleston. Fcap. 8vo, 1s. net.

\section{COUNTY HISTORIES OF SCOT-} LAND. In demy 8 vo volumes of about 350 pp. each. With Maps. Price 7s. 6d. net.

FIFE AND KINROSS. By AENEAS J. G. MACKAY, LL.D., Sheriff of these Counties.

DUMFRIES AND GALLOWAY. By Sir Herbert Maxwell, Bart., M.P. Second Edition.

MORAY AND NAIRN. By CHARLES RAMPINI, LL.D., Sheriff of Dumfries and Galloway.

INVERNESS. By J. Cameron Lees, D.D.

ROXBURGH, SELKIRK, AND PEEBLES. By Sir GEORGE DOUGLAS, Bart.

ABERDEEN AND BANFF. By WILLIAM WATt, Editor of Aberdeen 'Daily Free Press.'
COUTTS, H. B. MONEY.

FAMOUS DUELS OF THE FLEET. By H. B. Money CouTts. With Coloured Frontispiece and Illustrations by N. Wilkinson. Crown 8 vo, 6 s.

CRAIK, SIR HENRY, K.C.B., M.P.

A CENTURY OF SCOTTISH HISTORY. From the Days before the ' 45 to those within living Memory. By Sir Henry Craik, K.C.B., M.A. (Oxon.), Hon. LL. D. (Glasgow). With Portraits. Demy 8vo, 10s. 6d. net.

CRAWFORD, ALEXANDER.

KAPAK. BY ALEXANDER CRAWFORD. Crown 8vo, 6s.

CRAWFORD, F. MARION.

SARACINESCA. By F. Marion CrawFORD, Author of 'Mr Isaacs,' \&c., \&c. Crown 8vo, 3s. 6d. Clieap Eäitior, 1s. net. People's Edition, 6d.

CROALL LECTURES.

(See under NICOL and ROBERTSON.)

CROSS, J. W.

IMPRESSIONS OF DANTE AND OF THE NEW WORLD. By J. W. Cross. Post 8vo, 6s.

THE RAKE'S PROGRESS IN FINANCE. Crown 8vo, 2s. net,

CUMMING, C. F. GORDON.

MEMORIES. By C. F. GORDON CUMMINa. Demy 8vo. Illustrated, 20s. net.

AT HOME IN FIJI. Post 8vo. Illustrated. Cheap Edition. 6s.

A LADY'S CRUISE IN A FRENCH MAN-OF-WAR. Post 8vo. Illustrated. Cheap Edition. 6s.

FIRE-FOUNTAINS. 2 vols. post 8 vo. Illustrated, $25 \mathrm{~s}$.

GRANITE CRAGS. Post svo. Illustrated. Cheap Edition. 6s.

WANDERINGS IN CHINA. Small post 8vo. Cheap Edition. 6s.

CURTIS, HARPER.

THE LORD DOLLAR (DON DINERO). By Harper Curtis. Crown 8vo, 6s.

CURTIS, MARGUERITE.

THE BIAS. By Marquerite CuRtis. Crown 8vo, 6s.

MARCIA: A TransCript From LifE. Crown 8vo, 6s.

OH! FOR AN ANGEL. Crown 8vo, 6 s.

DAVIES, J.

HESIOD AND THEOGNIS. (Ancient Classics for English Readers.) By J. Davies. Fcap. 8vo, 1s. net.

CATULLUS, TIBULLUS, AND PROPERTIUS. (Ancient Classics for English Readers.) F'ap. 8vo, ls. net. 
DAVIS, JESSIE AINSWORTH.

"WHEN HALF-GODS GO." By JessIE AINsworth Davis. Second Impression. Crown 8vo, 6s.

DE HAVEN, AUDREY.

THE SCARLET CLOAK. BY AUDREY DE HAVEN. Crown 8vo, 6s.

DESCARTES.

THE METHOD, MEDITATIONS, AND PRINCIPLES OF PHILOSOPHY OF DESCARTES. Translated from the original French and Latin. With a new Introductory Essay, Historical and Critical, on the Cartesian Philosophy. By Professor VE1Tch, LL. D. Fourteenth Edition. Crown 8vo, 6s. 6d.

"DIES IRAE." The Story of a Spirit in Prison. Second Edition. Crown 8vo, 1s. 6d. net. Paper cover, 1s. net.

\section{DIVER, MAUD.}

CAPTAIN DESMOND, V.C. By MaUd DIVER. Ninth Impression. Crown 8vo, 6s. Cheap Edition, 1s. net.

THE GREAT AMULET. Seventh Impression. Crown 8vo, 6s. Cheap Edition, 1s. net.

CANDLES IN THE WIND. Sixth Im. pression. Crown 8vo, 6s. Cheap Edition in the press.

THE ENGLISHWOMAN IN INDIA. Crown 8vo, 5s. net.

DODDS and MACPHERSON.

THE LICENSING ACTS (SCOTLAND) CONSOLIDATION AND AMENDMENT ACT, 1903. Annotated by J. M. Donds, C.B., of the Scottish Office; Joint-Editor of the 'Parish Council Guide for Scotland,' and Ewan MacPHerson, Advocate, Legal Secretary to the Lord Advocate. In 1 vol. crown 8 vo, 5 s. net.

DONNE, W. B.

EURIPIDES. (Ancient Classics for Eng. lish Readers.) By W. B. Donne, Fcap. 8vo, 1s. net.

TACITUS. (Ancient Classics for English Readers.) Fcap. 8vo, 1s. net.

DOUGLAS, CHARLES, M.A., D.Sc. THE ETHICS OF JOHN STUART Mitul. By Charles Douglas, M.A., D.Sc., late Lecturer in Moral Philosophy, and Assistant to the Professor of Moral Philosophy in the University of Edinburgh. Post 8vo, 6s. net.

JOHN STUART MILI: A STUDY OF his Philosophy. Crown 8vo, 4s. 6d. net.
DURAND, SIR H. MORTIMER.

A HOLIDAY IN SOUTH AFRICA By the Right Hon. Sir H. M. DuRand, G.C.M.G., K.C.S.I., \&c. Crown 8vo, 6s. net.

ECCOTT, W. J.

FORTUNE'S CASTAWAY. By W. J. EсCOTT. Crown 8vo, 6s.

HIS INDOLENCE OF ARRAS. CrOWn $8 \mathrm{vo}, 6 \mathrm{~s}$.

THE HEARTH OF HUTTON. Crown $8 \mathrm{vo}, 6 \mathrm{~s}$.

THE RED NEIG 6s. Cheap Edition, 1s, net.

THE BACKGROUND. Crown 8vo, $6 \mathrm{~s}$.

A DEMOISELLE OF FRANCE. Crown $8 \mathrm{vo}, 6 \mathrm{~s}$.

ELIOT, GEORGE.

THE NEW PUPULAR EDITION OF GEORGE ELIOT'S WORKS, with Photogravure Frontispiece to each Volume, from Drawings by William Hatherell, R.I., Edgar Bundy, R.I., Byam Shaw, R.I., A. A. Van Anrooy, Maurice Greiffenhagen, Claude A. Shepperson, R.I., E. J. Sullivan, and Max Cowper. Each Work complete in One Volume. Handsomely bound, gilt top. 3s. 6d. net. Ten Volumes in all.

ADAM BEDE.

Scenes of Clerical Life.

The Mill on the Floss.

Felix Holt, the Radical.

MIDDLEMARCH.

Silas Marner; Brother Jacob; The Lifted Veil.

ROMOLA.

Daniel Deronda.

The Spanish Gypsy; Jubal.

Essays; Theophrastus SUCH.

GEORGE ELIOT'S LIFE. With Portrait and other Illustrations. New Edition, in one volume. Crown Svo, $7 \mathrm{~s} .6 \mathrm{~d}$.

LIFE AND WORKS OF GEORGE ELIOT (Warwick Edition). 14 volumes, cloth, limp, gilt top, $2 \mathrm{~s}$. net per volume; leather, limp, gilt top, 2s. 6d. net per volume; leather, gilt top, with bookmarker, $3 \mathrm{~s}$. net per volume.

ADAM BEDE. $826 \mathrm{pp}$.

The Mill on the Floss. $828 \mathrm{pp}$.

Felix Holt, the Radical. $718 \mathrm{pp}$.

RoMola. $900 \mathrm{pp}$.

SCENES of Clerical Life. $624 \mathrm{pp}$

SilAS MARNER; Brother JacoB; THE LIF'ED VEIL. $560 \mathrm{pp}$.

MIDDLEMARCH. 2 vols. 664 and $630 \mathrm{pp}$.

DANiel Deronda. 2 vols. 616 and $636 \mathrm{pp}$.

The Spanish Gypsy; Jubal.

Essays; Theophrastus SUCH.

LIFE. 2 vols., 626 and 580 pp. 
ELIOT, GEORGE-contd.

WORKS OF GEORGE ELIOT (Standard Edition). 21 volumes, crown 8 vo. In buckram cloth, gilt top, 2s. 6d. per vol. ; or in roxburghe binding, $3 \mathrm{~s}$. $6 \mathrm{~d}$. per vol. ADAM BEDE. 2 vols.

ThE MrLl oN THE Floss. 2 vols.

Felix Holt, the Radical. 2 vols. ROMOLA. 2 vols.

SCEnes of Clerical Life. 2 vols.

MiddlemarCH. 3 vols.

DANIEL DERONDA. 3 vols.

Silas Marner. 1 vol.

JUBAL. 1 vol.

The SPANISH GyPSY. 1 vol.

Essays. 1 vol.

Theophrastus Such. $1 \mathrm{vol}$.

LIFE AND WORKS OF GEORGE ELIOT (Cabinet Edition). 24 volumes, crown $8 v 0$, price $£ 6$. Also to be had handsomely bound in half and full calf. The Volumes are sold separately, bound in cloth, price $5 \mathrm{~s}$. each.

NOVELS BY GEORGE ELIOT. Popu. lar copyright Edition. In new uniform binding, price $3 \mathrm{~s}$. $6 \mathrm{~d}$. each.

ADAM Bede.

The Mill on the Floss.

Scknes of Clerical Life.

Romola.

Felix Holt, the Radical.

Silas Marner; The Lifted Veil; BROTHER JACOB.

Middlemarch.

DANIEL DERONDA.

ESSAYS. New Edition. Crown 8vo, $5 \mathrm{~s}$.

IMPRESSIONS OF THEOPHRASTUS SUCH. New Edition. Crown 8vo, 5s.

THE SPANISH GYPSY. New Edition. Crown 8vo, $5 \mathrm{~s}$.

THE LEGEND OF JUBAL, AND OTHER Poems, OLd aNd New. New Edition. Crown 8vo, 5 s.

SILAS MARNER. New Edition, with Illustrations by Reginald Birch. Crown 8vo, 1s. 6d. net. Cheap Edition, 2s. 6d.

SCENES OF CLERICAL LIFE. Cheap Edition, 3s. Illustrated Edition, with 20 Illustrations by H. R. Millar, crown 8 vo, 2s. 6d. ; plain cloth, 2s. ; paper covers, Is.

ADAM BEDE. New Edition, crown 8vo, paper cover, 1s. ; crown 8vo, with Illustrations, cloth, $2 \mathrm{~s}$.

THE MILL ON THE FLOSS. New Edition, paper covers, 1s. ; cloth, $2 \mathrm{~s}$.

WISE, WITTY, AND TENDER SAY. INGS, IN PROSE AND VERSE. Selected from the Works of GEORGE Elot. New Edition. Fcap. 8vo, 3s. $6 \mathrm{~d}$.

ELLIS, BETH.

MADAMH, WILL YOU WALK By Beth Eliss. Crown 8vo, $6 \mathrm{~s}$.
ELLIS, BETH-contd.

BLIND MOUTHS. Crown 8vo, $6 \mathrm{~s}$.

THE MOON OF BATH. Fourth Impression. Crown 8vo, 6s. Cheap Edition, Is. net.

THE KING'S SPY. Second Impression. Crown 8vo, 6s.

\section{ELTON, PROFESSOR.}

THE AUGUSTAN AGES. By OLIVRR Elton, M.A., Professor of English Literature, University College, Liverpool. Crown 8 vo, 5s. net.

EVERARD, H. S. C.

HISTORY OF THE ROYAL AND ANCIENT GOLF CLUB, ST AN. DREWS. By H. S. C. EVERARD. With Eight Coloured Portraits. Crown 4to, 21s. net.

F.

STORIES OF THE ENGLISH. By F. With 50 Illustrations: Crown 8vo, 3s. 6d. net.

FERRIER, PROFESSOR.

PHILOSOPHICAL REMAINS. Crown $8 \mathrm{vo}, 14 \mathrm{~s}$.

FITZGERALD, JOHN ZACHARY.

RUTH WERDRESS, FATHER O'HARALAN, $\triangle N D$ SOME NEW CHRISTIANS. AN ANglo-Irish Tale. By JoHN ZaChary FitzGerald. Crown $8 \mathrm{vo}, 6 \mathrm{~s}$.

FLINT, PROFESSOR,

PHILOSOPHY AS SCIENTIA SCIENTIARUM. A History of Classifications of the Sciences. By ROBERT FLINT, D.D., LL.D., Corresponding Member of the Institute of France, Professor in the University of Edinburgh, \&c. 10s. 6d. net.

STUDIES ON THEOLOGICAL, BIBLI. CAL, AND OTHER SUBJECTS. 7s. 6d. net.

HISTORICAL PHILOSOPHY IN FRANCE AND FRENCH BELGIUM AND SWITZERLAND. 8vo, 21s.

THEISM. Tenth Edition, Revised. Crown $8 \mathrm{vo}, 7 \mathrm{~s} .6 \mathrm{~d}$.

ANTI-THEISTIC THEORIES. Fifth Edition. Crown 8vo, 10s. 6d.

VICO. (Philosophical Classics for English Readers.) Fcap. 8vo, 1s, net.

FOREIGN CLASSICS FOR ENGLISH READERS. Edited by Mrs Oliphant. Price is. each net. For List of Vols. see p. 32.

FORREST, G. W., C.I.E.

HISTORY OF THE INDIAN MUTINY. By G. W. Forrest, C.I.E. Ex-Director of Records, Government of India. 2 vols. demy 8 vo, 38 s. net. 
FORREST, G. W., C.I.E.-contd. LIFE OF FIELD-MARSHAL SIR NEVJLLE B. CHAMBERLAIN, G.C.B., G.C.S.I. With two Photogravure Portraits. Demy 8vo, 18s. net.

FORSTER, E. M.

WHERE ANGELS FEAR TO TREAD. By E. M. Forster. Crown $8 v o, 6 s$.

THE LONGEST JOURNEY. Second Impression. Crown 8vo, $6 \mathrm{~s}$.

\section{FOULIS, HUGH.}

THE VITAL SPARK. By Hugh Fouls. Illustrated. 1\%. net.

FRANKLIN, MILES.

SOME EVERYDAY FOLK AND DAWN. By Miles Franklin. Crown 8vo, $6 \mathrm{~s}$. FRASER, PROFESSOR A. CAMP
BELL.

PHILOSOPHY OF THEISM. Being the Gifford Lectures delivered before the University of Edinburgh in 189496. By Alexander Campbell Fraser, D.C.L., Oxford; Emeritus Professor of Logic and Metaphysics in the University of Edinburgh. Second Edition, Revised. Post 8vo, 6s. 6d. net.

BIOGRAPHIA PHILOSOPHICA. In 1 vol. demy $8 \mathrm{vo}, 6 \mathrm{~s}$, net.

BERKELEY. (Philosophical Classics for English Readers.) Fcap. 8vo, 1s. net.

LOCKE. (Philosophical Classics for English Readers.) Fcap. 8vo, 1s. net.

\section{FRASER, DAVID.}

THE MARCHES OF HINDUSTAN. The Record of a Journey in Thibet, Trans-Himalayan India, Chinese Turkestan, Russian Turkestan, and Persia. By David Fraser. With Illustrations, Maps, and Sketches. Demy 8 vo, $\& 1,1$ s. net.

THE SHORT CUT TO INDIA. The Record of a Journey along the Route of the Baghdad Railway. With 83 Illustrations. Second Impression. Demy 8vo, 12s. 6 d. net.

PERSIA AND TURKEY IN REVOLT. With numerous Illustrations. Demy 8vo, 12s. 6d. net.

FRENCH COOKERY FOR ENGLISH HOMES. Fourth Impression. Crown 8vo, cloth, 2s. 6d. French morocen, 3s.

\section{FULTON, T. WEMYSS.}

THE SOVEREIGNTY OF THE SEA. An Historical Account of the Claims of England to the Dominion of the British Seas, and of the Evolution of the Territorial Waters: with special reference to the Rights of Fishing and the Naval Salute. By T. Wemrss Fulton, Lecturer on the Scientific Study of Fisheries Problems, The University, Aberdeen. With Charts and Maps. Demy 8vo, 25s. net.
FYFE, H. HAMILTON.

THE NEW SPIRIT IN EGYPT. By H. Hamilton Fyfe. With Illustrations. Crown 8vo, 5s. net.

GALT, JOHN.

THE PROVOST, \&c. By JoHN GALT. Illustrated boards, 2s. ; cloth, 2s. 6 d.

SIR ANDREW WYYLIE. Illustrated boards, 2s. ; cloth, 2s. 6d.

GENERAL ASSEMBLY OF THE CHURCH OF SCOTLAND.

SCOTTISH HYMNAL, WITH APPEN. DIX INCORPORATED. Published for use in Churches by Authority of the General Assembly. 1. Large type, cloth, red edges, 2s. 6d. ; French morocco, 4s. 2. Bourgeois type, limp cloth, 1s.; French morocco, 2s. 3. Nonpareil type, cloth, red edges, 6d.; French morocco, 1s. 4d. 4. Paper covers, 3d. 5. Sunday-School Edition, paper covers, 1d. ; cloth, 2d. No. 1, bound with the Psalms and Paraphrases, French moroceo, $8 \mathrm{~s}$. No. 2, bound with the Psalms and Paraphrases, cloth, 2s. ; French morocco, 3s.

SERVICES OF PRAYER FOR SOCIAL AND FAMILY WORSHIP. Prepared by a Special Committee of the General Assembly of the Church of Scotland. New Edition, Revised and Enlarged. Fcap. 8vo, red edges, 1s. 6d. net.

PRAYERS FOR FAMILY WORSHIP. A Selection of Four Weeks' Prayers. New Edition. Authorised by the General Assembly of the Church of Scotland. Fcap. 8vo, red edges, 1s. net.

ONE HUNDRED PRAYERS. Prepared by the Committee on Aids to Devotion. $16 \mathrm{mo}$, cloth limp, 6d. net.

MORNING AND EVENING PRAYERS FOR AFFIXING TO BIBLES. Prepared by the Committee on Aids to Devotion. 1d. for 6, or 1s. per 100.

PRAYERS FOR SOLDIERS. Prepared by the Committee on Aids to Devotion. Seventieth Thousand. $16 \mathrm{mo}$, cloth limp, 2d. net.

PRAYERS FOR SAILORS AND FISHER - FOLK. Prepared and Published by Instruction of the General Assembly of the Church of Scotland. Fcap. 8vo, 1s. net.

GERARD, E. D.

REATA: WHAT'S IN A NAME. By E. D. Gerard. Cheap Edition. Crown 8vo, 3s. 6d.

BEGGAR MY NEIGHBOUR. Cheap Edition. Crown 8vo, 3s. 6d.

THE WATERS OF HERCULES. Cheap Edition. Crown 8vo, 3s. 6d.

A SENSITIVE PLANT. Crown 8vo, $3 s .6 \mathrm{~d}$. 
GERARD, E.

HONOUR'S GLASSY BUBBLE. By

E. Glrard. Crown $8 v 0,6 \mathrm{~s}$.

A FOREIGNER. An Anglo-German Study. Crown 8vo, 6s.

\section{GERARD, DOROTHEA.}

ONE YEAR. By Dorothea GrRard (Madame Longard de Longgarde). Crown 8vo, 6s.

THE IMPEDIMENT. Crown $8 \mathrm{vo}, 6 \mathrm{~s}$.

A SPOTLESS REPUTATION. Third Edition. Crown 8vo, 6s.

THE WRONG MAN. Second Edition. Crown 8vo, 6s.

LADY BABY. Cheap Edition. Crown 8vo, 3s. 6d.

RECHA. Crown 8vo, 6s.

A FORGOTTEN SIN. Crown $8 \mathrm{vo}, 6 \mathrm{~s}$.

GERARD, REV. J.

STONYHURST LATIN GRAMMAR. By Rev. J. Gerard. Second Edition. Feap. 8vo, 3s.

GIBBON, PERCEVAL.

SOULS'IN BONDAGE. By Perceval GibBon. Crown 8vo, 6s.

THE VROUW GROBELAAR'S LEADING CASES. Crown 8vo, $6 \mathrm{~s}$.

SALVATOR. Crown 8vo, 6s.

GIFFORD LECTURES, EDINBURGH. (See under Fraser and TIELE.)

GILL, RICHARD.

THE CHCL - PROBLEM. By RICHARD GILL. 2 vols. crown 8 vo, 5s. net each.

GILLANDERS, A. T.

FOREST ENTOMOLOGY. By A. T. GILLANDERs, F.E.S. With Illustrations. Crown 8 vo, 15s. net.

GILLESPIE, REV. JOHN, LL.D.

THE HUMOURS OF SCOTTISH LIFE. By the Rev. John Gillespie, LL.D. Crown 8vo, 3s. 6d. net.

\section{GLASGOW BALLAD CLUB.}

BALI,ADS AND POEMS. By MEMBERS of the Glasgow Ballad Club. Crown 8 vo, 7s. 6d. net. Third Series, 7s. 6d.

GLEIG, REV. G. R.

THE SUBALTERN, By Rev. G. R. Gleig. Feap. 8vo, 1s. net.

GRAHAM, HENRY GREY.

ROUSSEAU. (Foreign Classics for English Readers.) By Henry Grey GrAHAM. Feap. 8vo, 1s. net.
GRAHAM, J. EDWARD, K.C.

A MANUAL OF THE ACTS RELATING TO EDUCATION IN SCOTLAND. (Founded on that of the late Mr Craig Sellar.) By J. EDWARD Graham, K.C., Advocate. New Edition. Demy 8vo, 25s. net.

MANUAL OF THE ELECTIONS (SCOT.) (CORRUPT AND ILLEGAL PRACTICES) ACT, 1890. With Analysis, Relative Act of Sederunt, Appendix containing the Corrupt Practices Acts of 1883 and 1885, and Copious Index. 8vo, 4s. 6d.

THE NEW EDUCATION (SCOTLAND) ACT. With Notes. Demy 8vo, 7s. 6d. net.

GRAHAM, E. MAXTONE, and PATERSON, E.

TRUE ROMMANCES OF SCOTLAND. By E. Maxtone Graham and E. Paterson. Illustrations. Second Impression. Crown 8vo, 5s. net.

GRAND, SARAH.

SINGULARLY DELUDED. By SaraH GraND. Crown 8vo, 6s.

GRANT, SIR ALEX.

XENOPHON. (Ancient Classics for English Readers.) By Sir Alex. Grant. Fcap. 8vo, 1s. net.

ARISTOTLE. (Ancient Classics for English Readers.) Feap. 8vo, 1s. net.

GRANT, CAPTAIN M. H. ("LINESMAN.")

THE MÁKERS OF BLACK BASALTES. By Captain M. H. Grant ("LinesMAN"). Illustrating nearly 300 pieces. Demy 4to, 42s. net.

GRETTON, LIEUT.=COLONEL G. LE $M$.

CAMPAIGNS AND HISTORY OF THE 1Sth ROYAL IRISH REGIMENT. By Lievt.-Colonel G. Le M. GRetTON. 4to. Illustrated.

\section{GREY, DULCIBELLA ETHEL.}

POEMS. By DULCIBELlA ETHEL GRey. With a Prefatory Note by H. Cholmondeley Pennell. Demy 8vo. Vellum, 12s. 6d. net; half vellum, 7s. 6d. net.

GRIER, SYDNEY C.

HIS EXCELLENCY'S ENGLISH GOVERNESS. By SYDNEY C. GRIER. Third Impression. Crown 8vo, $6 \mathrm{~s}$.

AN UNCROWNED KING: A ROMANCE of High Politics. Third Impression Crown 8vo, 6s.

PEACE WITH HONOUR, Third Impression. Crown 8vo, 6s. 
GRIER, SYDNEY C.-contd.

A CROWNED QUEEN : The RoMance of A Minister of State. Third Impression. Crown 8vo, 6s.

LIKE ANOTHER HELEN. Second Impression. Crown 8vo, $6 \mathrm{~s}$.

THE KINGS OF THE EAST: A ROMANCE OF THE NEAR FUTURE. Fourth Impression. Crown 8vo, 6s.

THE PRINCE OF THE CAPTIVITY. Second Impression. Crown 8vo, 6s.

THE GREAT PROCONSUL. The Memoirs of Mrs Hester Ward, formerly in the family of the Hon. Warren Hastings, Esq., late Governor-General of India. Crown 8vo, 6s.

THE HEIR. Crown 8vo, 6s.

THE POWER OF THE KEYS. With Illustrations by A. Pearce. Fourth Impression. Crown 8vo, 6s. Cheap Edition, 1s. net.

THE HERITAGE. Fourth Impression. Crown 8vo, 6s.

THE PATH TO HONOUR, Third Impression. Crown 8vo, 6s.

THE PRIZE. Crown 8 vo, 6 s.

THE LETTERS OF WARREN HASTINGS TO HIS WIFE. Demy 8vo, 6s. net.

GRIERSON, PROFESSOR H. J. C.

THE FIRST HALF OF THE SEVENTEENTH CENTURY. (Periods of European Literature.) By Professor H. J. C. Grierson. Crown 8vo, 5s. net.

GRIERSON, MAJOR = GENERAL J. M., C.V.O., C.B., C.M.G.

RECORDS OF THE SCÓTTISH VOL UNTEER FORCE, 1859-1908. By Major-General J. M. Grierson, C.V.O., C.B., C.M.G. With 47 Coloured Plates. Crown 4to, 25s. net.

GRIFFIN, E. ACEITUNA.

LADY SARAH'S DEED OF GIFT. By E. Aceituna Griffin. Crown 8vo, 6s.

A SERVANT OF THE KING. Crown 8 vo, 6s.

GROOT, J. MORGAN DE.

THE AFFAIR ON THE BRIDGE. By J. Morgan dF Groot. Crown 8vo, $6 \mathrm{~s}$. A LOTUS FLOWER. Crown $8 v o, 6 s$. EVEN IF. Crown 8vo, 6s.

JAN VAN DYCK. Crown 8vo, 6s.

THE BAR SINISTER. Crown $8 v 0,6 \mathrm{~s}$.

HAMERTON, P. G.

WEN DERHOLME. By P. G. HAMERTON. Crown 8vo, 3s. 6d.

MARMORNE. Crown 8vo, 3s. 6d.
HAMILTON, CAPTAIN.

CYRIL THORNTON. By Captain HAMILTON. Illustrated boards, 2s. ; cloth, 2s. $6 \mathrm{~d}$.

HAMILTON, MARY, D. Litt.

GREEK SAINTS AND THEIR FESTIVAls. By Mary Hamilton, D.Litt. Crown 8vo, 5s, net.

HAMLEY, GENERAL SIR EDWARD BRUCE, K.C.B., K.C.M.G.

THE OPERATIONS OF WAR EX. PLAINED AND ILLUSTRATED. By General Sir lidward Bruce Hamley, K.C.B., K.C.M.G.

A New Edition, brought up to the latest requirenients. By BrigadierGeneral L. E. Kiggell, C.B. 4to, with Maps and Plans, $30 \mathrm{~s}$.

THOMAS CARLYLE: AN EssAT. Second Edition. Crown 8vo, 2s. 6d.

ON OUTPOSTS. Secund Edition. 8vo, $2 s$.

LADY LEE'S WIDOWHOOD. Crown 8vo, 3s. 6d.; New Edition, crown 8vo, 2s. ; cloth, 2s. 6 d.

VOLTAIRE. (Foreign Classics for English Readers.) Fcap. 8vo, 1s. net.

\section{HANNAY, DAVID.}

THE LATER RENAISSANĆE. "Periods of European Literature." By DAviD Hannay. Crown 8vo, 5s, net.

SHIPS AND MEN. With Illustrations. Crown 8vo, 6s. net.

HARDMAN, F.

PENINSULAR SCENES AND SKETCHES. By F. HARdMAN. Jllus. trated cover, 1s. ; cloth, 1s. 6d.

HARRADEN, BEATRICE.

SHIPS THAT PASS IN THE NIGHT. By BEATrice Harraden. Illustrated Edition. Crown 8vo, 3s. 6d.

THE FOWLER. Illustrated Edition. Crown 8vo, 3s. 6d.

UNTOLD TALES OF THE PAST. With 40 Illustrations by $\mathbf{H}$. R. Millar. Square crown $8 \mathrm{vo}$, gilt top, $5 \mathrm{~s}$. net.

KATHARINE FRENSHAM. Crown $8 \mathrm{vo}, 6 \mathrm{~s}$.

HARTLEY, GILFRID W

WILD SPORT WITH GUN, RIFLE, AND SALMON-ROD. By GILFRID W. HARTLEY. With numerous Illustrations in photogravure and half-tone from drawings by G. E. Lodge and others. Demy 8vo, 6s. net. 
HASELL, E. J.

CALDERON. (Foreign Classies for English Readers.) By E. J. Hasell. Fcap. 8vo, 1s net.

TASSO. (Foreign Classics for English Readers.) Fcap. 8vo, 1s. net.

\section{HAY, BISHOP.}

THE WORKS OF THE RIGHT REV. DR GEORGE HAY, Bishop of Edinburgh. Edited under the supervision of the Right Rev. Bishop Strain. With Memoir and Portrait of the Author. 5 vols. crown $8 \mathrm{vo}, 21 \mathrm{~s}$.

HAY, IAN.

"PIP." By Ian HaY. Fourth Impression. Crown 8vo, 6s. Cheap Edition, 1s. net.

"THE RIGHT STUFF." Some Episodes in the Career of a North Briton. Fifth Impression. Crown 8vo, 6s. Cheap Edition in the press.

A MAN'S MAN. Third Impression. Crown 8vo, 6s.

HAYLLAR, FLORENCE.

NEPENTHES. By FloRence Hayllar. Second Impression. Crown 8vo, 6s.

HAYWARD, A., Q.C.

GOETHE. (Foreign Classics for English Readers.) By A. HAYWARD, Q.C. Fcap. 8vo, 1s. net.

HEATH, CHRISTOPHER.

PETER'S PROGRESS. BY CHRISTOPHER HeATH. Crown 8vo, $6 \mathrm{~s}$.

HEMANS, MRS.

SELECT POEMS OF MRS HEMANS. Feap., cloth, gilt edges, 3s.

HENDERSON, P. A. WRIGHT.

THE LIFE AND TIMES OF JOHN WILKINS, Warden of Wadham College, Oxford; Master of Trinity College, Cambridge; and Bishop of Chester. By P. A. Wright Henderson. With Illustrations. Pott 4to, 5s. net.

HENDERSON, RICHARD.

THE YOUNG ESTATE MANAGER'S GUIDE. By RICHARD HENDERSON, Member (by Examination) of the Royal Agricultural Society of England, the Highland and Agricultural Society of Scotland, and the Surveyors' Institution. With an Introduction by Professor WRIGHT, Glasgow and West of Scotland Technical College. With Plans and Diagrams. Crown 8vo, 5s.

HERFORD, PROFESSOR.

BROW NING. "Modern English Writers." By C. H. Herford, Litt.D., Professor of English Literature, University of Manchester. 2s. 6d.
HERKLESS, PROFESSOR, and HANNAY, ROBERT KERR.

THE COLLEGE OF ST LEONARD'S. By John Hrkkless, Professor of Ecclesiastical History in the University of St Andrews; and ROBERT KERR HANNAY, Lecturer in Ancient History in the University of St Andrews. Post 8 vo, 7s. 6d. net.

THE ARCHBISHOPS OF ST ANDREWS. 3 vols. demy 8vo, each 7s. 6 d. net.

HINTS ON HOCKEY. With Plans and Rules. New Edition. Fcap. 8vo, 1 s.

HOBART = HAMPDEN, E.

THE PRICE OF EMPIRE. By E. HoвaRt-Hampden. Crown 8vo, $6 \mathrm{~s}$.

HOOK, DEAN.

PEN' OWEN. By Dean Hook. Illustrated boards, 2 s. ; cloth, $2 \mathrm{~s}$. 6 d.

HOPE, JAMES F.

A HISTORY OF THE 1900 PARLIAMENT. By JAMES F. HOPE. In two volumes. Vol. I. Crown 8vo, 7s. 6 d. net.

\section{HUME, DAVID.}

DIALOGUES CONCERNING NAT. URAL RELIGION. By David Hume. Reprinted, with an Introduction by Bruce M'Ewen, D.Phil. Crown 8vo, 3s. 6d. net.

HUNT, C. M. $G$.

A HANDY VOCABULARY : ENGLISHAFrikander, AFrIKANDER - ENGLish. By C. M. G. HuNt. Small 8vo, $1 \mathrm{~s}$.

HUTCHINSON, HORACE $G$.

HINTS ON THE GAME OF GOLF. By Horace G. Hutchinson. Twelfth Edition, Revised. Fcap. 8vo, cloth, 1s.

HUTTON, EDWARD.

ITALY AND THE ITALIANS. By EDWARD HutTon. With Illustrations. Second Edition. Large crown 8vo, 6s.

INNES, A. TAYLOR, LL.D.

FREE CHURCH UNION CASE. Judg. ment of the House of Lords. With Introduction by A. TAYLOR INNES, LL.D. Demy 8vo, 1s. net.

THE LAW OF CREEDS IN SCOTLAND. A Treatise on the Relations of Churches in Scotland, Established and not Established, to the Civil Law. Demy 8vo, 10s. net.

INTELLIGENCE OFFICER.

ON THE HEELS OF DE WET. By THE INTELLigence OrFicer. Sixth Impression. Crown 8vo, 6s. 
INTELLIGENCE OFFICER-contd. THE YELLOW WAR. Crown 8vo, $6 \mathrm{~s}$. A SUBALTERN OF HORSE. Second Impression. Crown $8 \mathrm{vo}, 6 \mathrm{~s}$.

IRONS, DAVID, M.A., Ph.D.

THE PSYCHOLOGY OF ETHICS. By David Irons, M.A., Ph.D., Professor of Philosophy in Bryn Mawr College, Penn. Crown 8vo, 5s. net.

JAMES, ANDREW.

NINETY-EIGHT AND SIXTY YEARS AFTER. By ANDREW James. Crown 8vo, 3s. $6 \mathrm{~d}$.

JAMES, LIONEL.

SIDE-TRACKS AND BRIDLE-PATHS. By LiONEL JAMES (Intelligence Officer). Crown 8vo, 6 s.

JAMES, LIEUT.=COL. WALTER H. MODERN STRATEGY. By Lieut.-Col. WALter H. JAMES, P.S.C., late R.E. With 6 Maps. Third Edition, thoroughly revised and brought up to date. Royal 8vo, $16 \mathrm{~s}$. net.

THE CAMPAIGN OF 1815, CHIEFLY IN FLANDERS. With Maps and Plans. Deny 8 vo, 16s. net.

THE DEVELOPMENT OF TACTICS FROM 1740 TO THE PRESENT DAY. Demy 8vo. [In the press.

\section{JOHNSTON.}

ELEMENTS OF AGRICULTURAL CHEMISTRY. An entirely New Edition from the Edition by Sir CHARLES A. Cameron, M.D. Revised and in great part rewritten by C. M. AIKMAN, M.A., D.Sc., F.R.S.E., F.I.C., Professor of Chemistry, Glasgow Veterinary College. 20th Edition. Crown 8vo, 6s. 6d.

CATECHISM OF AGRICULTURAL CHEMISTRY. An entirely New Edition from the Edition by Sir CHARLFS A. Cameron. Revised and enlarged by C. M. AIKMAN, D.Sc., \&c. 95th Thousand. With numerous Illustrations. Crown 8vo, 1s.

JOHNSTON, K.C., LL.D.

AGRICULTURAL HOLDINGS (SCOTLAND) ACTS, 1883 to 1900 ; and the GROUND GAME ACT, 1880. With Notes, and Summary of Procedure, \&c. By CHRistopher N. JoHnston, K.C., LL.D. Sixth Edition. Demy 8vo, $6 \mathrm{~s}$.
net.

MAJOR OWEN, AND OTHER TALES. Crown 8vo, 6s.
JOKAI, MAURUS.

TIMAR'S TWO WORLDS. By MAURUS JokaI. Authorised Translation by Mrs HEGAN KENNaRd. Cheap Edition. Crown 8 vo, $6 \mathrm{~s}$.

JORDAN, HUMFREY.

MY LADY OF INTRIGUE. By HUMFREY JORDAN. Crown 8vo, 6s.

KENNION, MAJOR R. L.

SPORT AND LIFE IN THE FURTHER HIMALAYA. By MAJOR R. L. KenNron. With Illustrations. Demy 8vo, 12s. 6 d. net.

KER, PROFESSOR W. P.

THE DARK AGES. "Periods of European Iiterature." By Professor W. P. KER. In 1 vol, crown $8 v 0$, 5s, net.

KERR, JOHN, LL. D.

MEMORIES: GRAVE AND GAY. By JoHN KerR, LI.D. With Portrait and other Illustrations. Cheaper Edition, Enlarged. Crown 8vo, 2s. 6d. net.

OTHER MEMORIES: OLD AND NEW. Crown 8 vo. 3s. 6 d. net.

KINGLAKE, A. W.

HISTORY OF THE INVASION OF THE CRIMEA. By A. W. KiNGLAKE. Complete in 9 vols. crown 8vo. Cheap reissue at $3 \mathrm{~s} .6 \mathrm{~d}$. each.

Abridged Erlition for Military Students. Revised by Lieut.-Col. Sir George Sydenham Clarke, G.C.M.G., G.C.I.E. Demy 8vo, 15s. net. 9s. net.

Atlas to accompany above. Folio,

EOTHEN. Cheap Edition. With Portrait and Biographical Sketch of the Author. Crown 8vo, 2s. 6d. net.

\section{KINGSBURGH, THE RIGHT HON.} LORD, K.C.B.

FIFTY YEARS OF IT : THE EXPERIENCES AND STRUGGLES OF A VOLUNTRER of 1859. By The Right Hon. Lord Kinosburah, K.C.B. Demy 8 vo, $10 \mathrm{~s}$. 6d. net.

KNEIPP, SEBASTIAN.

MY WÁTER-CURE. As Tested through more than Thirty Years, and Described for the Healing of Diseases and the Preservation of Health. By SEBASTIAN KNEIPP. With a Portrait and other Illustrations. Authorised English Translation from the Thirtieth German Edition, by A. de F. With an Appendix, containing the Latest Developments of Pfarrer Kneipp's System, and a Pro face by E. Gerard. Crown $8 \mathrm{vo}_{2}$ 3s. $6 \mathrm{~d}$. 


\section{KNIGHT, PROFESSOR.}

HUME. (Pliilosophical Classies for English Readers.) By Professor Knıнт. Feap. 8 vo, 1s. net.

LANG, ANDREW.

A HISTORY OF SCOTLAND FROM THE ROMAN OCCUPATION. By ANDREW LANG. Complete in Four Volumes. Deiny 8vo, £3, 3s. net.

Vol. I. With a Photogravure Frontispiece. 15s. net.

Vol. II. With a Photogravure Frontispiece. 15s. net.

Vol. III. With a Photogravure Frontispiece. 15s. net.

Vol. IV. With a Photogravure Frontispiece. 20s. net.

TENNYSON. "Modern English Writers." Second Edition. Crown 8vo, 2s. 6d.

A SHORT HISTORY OF SCOTLAND. Crown 8vo, 5s. net.

LAPWORTH, PROFESSOR.

INTERMEDIATE TEXT-BOOK OF GEOLOGY. By Charles Lapworth, LL.D., Professor of Geology, University, Birmingham. $5 \mathrm{~s}$.

LAWSON, W. R.

BRITISH ECONOMICS. By $W$. $R$. LAwson. Second Edition. Crown svo, 6s. net.

AMERICAN FINANCE. Second Edition. Crown 8vo, 6s. net.

JOHN BULL AND HIS SCHOOLS. Crown 8vo, 5s. net.

CANADA AND THE EMPIRE. Crown 8 vo, 6s. net.

LEHMANN, R. C.

CRUMBS OF PITY, AND OTHER VERSES ; TO WHICH ARE ADDED SIX Lives OF Great Men. By R. C. Lehmann, author of 'Anni Fugaces,' \&c. Crown 8vo, 5s. net.

LIGHT AND SHADE: AND OTHER Poems. Crown 8vo, 5s. net.

LEIGHTON, GERALD R., M.D.

THE LIFE - HISTORY OF BRITISH SERPENTS, AND THEIR LOCAL DISTRIBUTION IN THE BRITISH ISLES. By Gerald R. Leighton, M.D. With 50 Illustrations. Crown 8 vo, 5s. net.

LEISHMAN, VERY REV. T., D.D.

THE WESTMINSTER DIRECTORY. Edited, with an Introduction and Notes, by the Very Rev. T. Leishman, D.D. Crown 8vo, 4s. not.

LEWIS, ARTHUR.

THE PILGRIM. By ARTHUR Lewis.
LINDSAY, REV. JAMES, D.D.

RECENT ADVANCES IN THEISTIC PHILOSOPHY OF RELIGION. By Rev. James LinDSAY, M.A., D.D., B.Sc., F.R.S.E., F.G.S. Demy 8vo, 12s. 6d.' net.

THE PROGRESSIVENESS OF MODERN CHRISTIAN THOUGHT. Crown 8vo, 6s.

ESSAYS, LITERARY AND PHILOSO. PHICAL. Crown 8vo, 3s. 6d.

THE SIGNIFICANCE OF THE OLD TESTAMENT FOR MODERN THEOLOGY. Crown 8vo, 1s. net.

THE TEACHING FUNCTION OF THE MODERN PULPIT. Crown 8vo, $1 \mathrm{~s}$. net.

STUDIES IN EUROPEAN PHILOSOPHY. Demy 8vo, 10s. 6d. net.

THE FUNDAMENTAL PROBLEMS OF METAPHYSICS. Crown 8 vo, $4 \mathrm{~s}$. net.

THE PSYCHOLOGY OF BELIEF. Crown 8vo, 2s. 6d. net.

"LINESMAN.",

THE MAKERS OF BLACK BASALTES. By "Linesman." With nearly 300 Illustrations. Demy 4to, 42s. net.

\section{LITURGIES AND ORDERS OF} DIVINE SERVICE (CHURCH SERVICE SOCIETY).

THE SECOND PRAYER BOOK OF KING EDWARD THE SIXTH (1552). With Historical Introduction and Notes by the Rev. H. J. Wothrerspoon, M.A., of St Oswald's, Edinburgh; and THE Lituray OF CoMpromise. Used in the English Congregation at Frankfort. From an Unpublished MS. Edited by the Rev. G. W. SprotT, D.D. 4s. net.

BOOK OF COMMON ORDER. COMmonly called KNOX's Lituray. Edited by Rev. G. W. SPRotT, D.D. 4s. 6d. net.

SCOTTISH LITURGIES OF THE REIGN OF JAMES VI. Edited by Rev. G. W. SPROTT, D.D. 4s. net.

LITURGY OF 1637. Commonly called LAUD's Lituray. Edited by the Rev. Professor CoOPER, D.D. 7s, 6d. net.

THE WESTMINSTER DIRECTORY. Edited by Very Rev. T. Leishman, D.D. 4s. net.

EUCHOLOGION. A Book of Common Order: Being Forms of Prayer, and Administration of the Sacraments, and other Ordinances of the Church. Edited by the Rev. G. W. Sprotr, D.D. 4s. 6d. net. 
LOBBAN, J. H., M.A.

AN ANTHOLOGY OF ENGLISH VERSE FROM CHAUCER TO THE PRESENT DAY. By J. H. LobBaN, M.A. Crown 8vo, gilt top, $5 \mathrm{~s}$.

THE SCHOOL ANTHOLOGY OF ENGLISH VERSE. Part I., Chaucer to Burns, cloth, 1s. net. Part II., Wordsworth to Newbolt, cloth, 1s. net. In One Volume complete, cloth, 2s. net.

LOCKHART, J. G.

REGINALD DALTON. By J. G. LOCKHART. Illustrated boards, $2 \mathrm{~s}$.; cloth, 2s. $6 \mathrm{~d}$.

ADAM BLAIR. Illustrated boards, 2s.; cloth, 2s. 6d.

VALERIUS: A ROMaN STORy. Illustrated cover, 1s.; cloth, 1s. 6 d.

LOCKHART, LAURENCE W. $M$.

DOUBLES AND QUITS. BY LAURENCE W. M. Lockhart. Crown 8vo, 3s. 6d.

FAIR TO SEE. Crown 8vo, 3s. 6 d.

MINE IS THINE. New Edition. Crown 8 vo, 3s. 6 d.

LORIMER, ADAM.

THE AUTHOR'S PROGRESS; OR, THE LITERARY BOOK OF THE ROAD. By Adam Lorimer. Crown 8vo, 5s. net.

LYNDEN=BELL, LIEUT = COLONEL. A PRIMER OF TACTICS, FORTIFICATION, TOPOGRAPHY, AND MILITARY LAW. By Lieut.-Colonel C. P. LYNDEN-Bell. With Diagrams. Crown $8 \mathrm{vo}, 3 \mathrm{~s}$. net.

MABIE, HAMILTON WRIGHT.

ESSAYS ON NATURE AND CULTURE. By Hamilton Wright Mabie. With Portrait. Feap. 8vo, 3s. 6d.

BOOKS AND CULTURE. Fcap. 8vo, 3s. $6 \mathrm{~d}$.

M'AULAY, ALLAN.

THE SAFETY OF THE HONOURS. By allan M'Aulay. Crown 8vo, 6s.

M'CONACHIE, WILLIAM, B.D. CLOSE TO NATURE'S HEART. By William M'Conachie, B.D. Crown 8vo, 3s. 6d. net.

MacCUNN, FLORENCE.

SIR WALTER SCOTT'S FRIENDS. By Florence MacCunn. With Portraits. Third Impression. Demy 8vo, 10s. net.

MACDONALD, NORMAN DORAN.

A MANUAL OF THE CRIMINAL LAW (SCOTLAND) PROCEDURE ACT, 1887. By Norman Doran Macdonald. Revised by the LORD JUSTICE - CLERK. $8 \mathrm{vo}, 10 \mathrm{~s} .6 \mathrm{~d}$.
MACDOUGALL, J. PATTEN, C.B., and $J . M$. DODD, C.B.

A MANUAL OF THE LOCAL GOV. ERNMENT (SCOTLAND) ACT, 1894. The Parish Council Guine for ScotLAND. By J. Patten MacDoveall, C.B., and J. M. DoDD, C.B. New and Revised Edition.

[In preparation.

M'IVER, IVER.

AN IMPERIAL ADVENTURE. By IvER M'IVER. With Illustrations, Crown $8 v 0,6 s$.

CAUGHT ON THE WING. Crown 8vo, 3s. 6 d, net.

\section{MACKAY, LYDIA MILLER.}

THE RETURN OF THE EMIGRANT. By Lydia Miller Mackay. Third Impression. Crown 8 vo, 6s.

MACKENZIE, LORD.

STUDIES IN ROMAN LAW. With Comparative Views of the I aws of France, England, and Scotland. By LORD MACKENZIE, one of the Judges of the Court of Session in Scotland. Seventh Edition, Edited by Jонм KIRKPATRICK, M.A., LL.D. Adrocate, Professor of History in the University of Edinburgh. 8 vo, 21 s.

MACKENZIE, W. A.

ROWTON HOUSE RHYMES. By W. A. Mackenzik. Crown 8vo, 3s. net.

MACKINLAY, J. M.

INFLUENCE OF THE PRE-REFORMATION CHURCH ON SCOTTISH PLACE-NAMES. By J. M. MACKINLAY, F.S.A. (Scot.) Demy 8vo, 12s.6d. net.

MACKINLAY, M. STERLING, M.A. GARCIA THE CENTENARIAN : AND his Trmes. Being a Memoir of Don Manuel Garcia's Life and Labours for the advancement of Music and Science. By M. Sterling Mackinlay, M.A. Oxon. With twenty Portraits. Demy $8 \mathrm{vo}, 15 \mathrm{~s}$. net.

MACNAMARA, RACHEL SWETE.

THE TRANCE. By RACHEL SWRTE Macnamara. Second Inipression. Crown 8vo, 6s.

THE SIBYL OF VENICE. Crown 8vo, $6 \mathrm{~s}$.

SEED OF FIRE. Crown $8 v 0,6 s$.

MACPHERSON, HECTOR.

BOOKS TO READ AND HOW TO READ THEM. By Hector MACPHERson. Second Impression. Crown 8vo, $3 \mathrm{~s} .6$ d. net.

A CENTURY'S INTELISECTUAL DEVELOPMENT. Crown 8vo, os. net.

A CENTURY OF POLITICAL DEVELOPMENT. 3s. 6d. net. 
MACPHERSON, HECTOR, JUN.

A CEN I'URY'S PROGRESS IN ASTRONOMY. By HECTOR MACPHERson, jun. Short demy $8 \mathrm{vo}$, 6s. net.

THROUGH THE DEPTHS OF SPACE: A Primer of Astronomy. Crown 8vo, 2s. net.

MACRAE, J. A.

FOR KIRK AND KING. By J. A. MACRAE. Crown 8vo, 6s.

MAHAFFY, PROFESSOR.

DESCARTES. (Philosophical Classics for English Readers.) By Professor MahafFy. Fcap. 8vo, 1s. net.

MAIR, REV. WILLIAM, D.D.

A DIGEST OF LAWS AND DECI. SIONS, Ecclesiastical and Civil, relating to the Constitution, Practice, and Affairs of the Church of Scotland. With Notes and Forms of Procedure. By the Rev. William Mair, D.D. New Edition, Revised. In 1 vol. crown $8 \mathrm{vo}, 12 \mathrm{~s} .6 \mathrm{~d}$. net.

SPEAKING; or, From VoICE Production to the Platform and PULPIt. Fourth Edition, Revised. Crown 8vo, 1s. 6 d. net.

MALLOCK, W. H.

LUCRE I'IUS. (Ancient Classies for Eng. lish Readers.) By W. H. Mallock. Fcap. 8vo, 1s. net.

MARSHMAN, JOHN CLARK, C.S.I. HISTORY OF INDIA. From the Earliest Period to the Present Time. By John Cla RK Marshman, C.S.I. Third and Cheaper Edition. Post 8vo, 6s.

MARTIN, SIR THEODORE, K.C.B.

HORACE. (Ancient Classies for English Readers.) By Sir Theodore Martin, K.C.B. Fcap. 8 vo, 1s. net.

POEMS OF GIACOMO LEOPARDI. Translated. Crown 8vo, 5s. net.

THE AENEID OF VIRGIL. Books I.-VI. Traiıslated. Post 8vo, 7s. 6d.

GOETHE'S FAUST. Part I. Translated into English Verse. Second Edition, crown $8 \mathrm{vo}, 6 \mathrm{~s}$. Ninth Edition, fcap. 8vo, 3s. 6d.

GOETHE'S FAUST. Part II. Translated into English Verse. Second Edition, Revised. Fcap. 8vo, 6s.

POEMS AND BALLADS OF HEINRICH HEINE. Done into English Verse. Third Edition. Small crown $8 \mathrm{vo}, 5 \mathrm{~s}$.

THE SONG OF THE BELL, AND OTHER Translations From Schiller, Goethe, UhLAND, AND others. Crown 8vo, 78.6 d.
MARTIN, SIR THEODORE-contd.

MADONNA PIA: A TRAGEDY ; AND THREe other Dramas. Crown 8vo, $7 \mathrm{~s} .6 \mathrm{~d}$.

THE 'VITA NUOVA' OF DANTE. Translated with an Introduction and Notes. Fourth Edition. Small crown $8 \mathrm{vo}, 5 \mathrm{~s}$.

Aladdin: A Dramatic Poem. By Adam Oehlenschlaeger. Fcap. 8vo, $5 \mathrm{~s}$.

CORREGGIO : A Tragedy. By OeHLENSCHLAEGER. With Notes. Fcap. 8vo, 3s.

HELENA FAUCIT (LAdY MaRTiN). By Sir THEODORE Martin, K.C.B., K.C.V.O. With Five Photogravure Plates. Second Edition. Demy 8vo, 10s. 6d. net.

POEMS AND BALLADS OF GOETHE. By Sir Theodore Martin and Professor Aytoun. Third Edition. With Introduction by Sir Theodore Martin. Small crown 8vo, 6s. net.

QUEEN VICTORIA AS I KNEW HER. Square crown $8 \mathrm{vo}, 3 \mathrm{~s}$. $6 \mathrm{~d}$. net.

MARTIN, HELENA FAUCIT, LADY. ON SOME OF SHAKESPEARE'S FEMALE CHARACTERS. By HELena Faucit, Lady Martin. Dedicated by permission to Her Most Gracious Majesty the Queen. With a Portrait by Lehmann. Seventh Edition, with a new Preface. Demy 8vo, 7s. 6d.

MASEFIELD, CHARLES.

GILBERT HERMER. BY CHARLES Masefield. Crown 8vo, $6 \mathrm{~s}$.

MASSON, DAVID.

MEMORIES OF LONDON IN THE FORTIES. By David Masson. Crown 8vo, 3s. 6d. net.

MATHESON, REV. GEORGE, D.D. CAN THE OLD FAITH LIVE WITH THE NEW? OR, THE Problem OF Evolution and Revelation. By the Rev. Georgk Matheson, D.D. Third Edition. Crown 8vo, 7s. 6d.

THE PSALMIST AND THE SCIENTIST; OR, MODERN VALUE OF THE Religious Sentiment. Third Edition. Crown 8vo, 5s.

SPIRITUAL DEVELOPMENT OF ST PAUL. Fourth Edition. Crown 8vo, $5 \mathrm{~s}$.

THE DISTINCTIVE MESSAGES OF THE OLD RELIGIONS. Second Edition. Crown $8 \mathrm{vo}, 5 \mathrm{~s}$.

SACRED SONGS. Third Edition. Crown 8vo, 2s. 6d.

MAXWELL, GERARD.

THE FEAR OF LIFE. By Gerard Maxwell. Crown 8vo, 6s. 
MAXWELL, RIGHT HON. SIR HERBERT, BART.

DUMFRIES AND GALLOWAY. By Right Hon. Sir HERBERT MAXWELL, Bart. Being one of the Volumes of the County Histories of Scotland. With Four Maps. Second Edition. Demy $8 \mathrm{vo}, 7 \mathrm{~s}$. 6d. net.

HOLYROOD, ABBEY CHURCH, PALACE, AND ENVIRONS. Crown 8vo. Paper cover, 6d. net; cloth, 2s. 6d. net.

MEAKIN, ANNETTE M. B.

WHAT AMERICA IS DOING. Letters from the New World. By AnNette M. B. Meakin. Demy 8vo, 10s. 6d. net.

\section{MELDRUM, DAVID $S$.}

THE CONQUEST OF CHARLOTTE. By David S. Meldrum. Third Impression. Crown 8vo, 6s.

THE STORY OF MARGRÉDEL: Being a Fireside History of a Fifeshire Family. Cheap Edition. Crown 8vo, 3s. $6 \mathrm{~d}$.

GREY MANTLE AND GOLD FRINGE. Crown 8vo, 6s.

MELLONE, SYDNEY HERBERT, M.A. D.Sc.

STUDIES IN PHILOSOPHICAL CRITICISM AND CONSTRUCTION. By Sydney Herbert Mellone, M.A. Lond., D.Sc. Edin. Post 8vo, 10s. 6d. net.

LEADERS OF RELIGIOUS THOUGHT IN THE NINETEENTH CENTURY. Crown 8vo, 6s. net.

AN INTRODUCTORY TEXT-BOOK OF LOGIC. Fourth Edition, Revised. Crown 8vo, $5 \mathrm{~s}$.

ELEMENTS OF PSYCHOLOGY. Second Impression. Crown 8vo, 5s.

THE IMMORTAL HOPE. Crown 8vo, 2s. $6 \mathrm{~d}$.

FREDERICK NIETZSCHE AND HIS ATTACK ON CHRISTIANITY. Demy 8 vo, paper cover, $3 \mathrm{~d}$.

\section{MERZ, JOHN THEODORE.}

A HISTORY OF EUROPEAN THOUGHT IN THE NINETEENTH CENTURY. By JOHN THEODORE Merz. Vol. I. Third Impression. Post 8vo, 10s. 6d. net. Vol. II., 15s. net.

LEIBNIZ. (Philosophical Classics for English Readers.) Fcap. 8vo, 1s. net.

MEYNELL, MRS.

JOHN RUSKIN. "Modern English Writers." By Mrs MeYnel. Third Impression. Crown 8vo, 2s. 6d.
MICKLETHWAIT, ST J. G., M.A., B.C.L.

THE LICENSING ACT, 1904. By St J. G. Mickiethwait, M.A., B.C.L., Barrister-at-Law. Crown 8vo, 2s. 6d. net.

\section{MILL, GARRETT}

THE COLONEL SAHIB. A Novel. By GarRetT Mill. Second Impression. Crown 8vo, 6s.

OTTAVIA. Second Impression. Crown $8 \mathrm{vo}, 6 \mathrm{~s}$.

MR MONTGOMERY : Foor, Crown $8 \mathrm{vo}, 6 \mathrm{~s}$.

IN THE HANDS OF THE CZAR. Crown 8vo, 6s.

THE CARDINAL'S SECRET. Crown 8vo, 6s.

CAPTAIN GRANT'S DESPATCH. Crown 8vo, 6s.

MILLAR, PROFESSOR J. H.

THE MID-EIGHTEENTH CENTURY.

"Periods of European Literature." By

J. H. MillaAr. Crown 8vo, 5s, net.

MILLER, WILLIAM, C.I.E., LL.D., D.D.

UNREST AND EDUCATION IN INDIA. By William Miller, C.I.E., LL.D., D.D., Principal of Madras Christian College. Demy 8vo, 1s. net.

MITCHELL, ALEXANDER F., D.D., LL. D.

THE SCOTTISH REFORMATION. Being the Baird Lecture for 1899. By the late Alexander F. Mitchell, D.D., LL.D. Edited by D. HAY Fleming, LL.D. With a Biographical Sketch of the Author, by James Christie, D.D. Crown Svo, 6s.

MITCHELL, REV. JAMES, D.D.

SIGNIFICANT ETYMOLOGY. By Rev. James Mitchell, D.D. Short demy, 8 vo, $7 \mathrm{~s}$. 6 d. net.

MODERN ENGLISH WRITERS. In handy crown 8vo volumes, tastefully bound, price $2 \mathrm{~s}$. $6 \mathrm{~d}$. each.

MATTHEW ARNOLD. By Professor SaINTsBury. Second Impression.

JOHN RUSKIN. By Mrs Meynell. Third Impression.

TENNYSON. By ANDREW LANG. Second Impression.

HUXLEY. By Edward Clodd.

THACKERAY. By CHARLES WHIBLEY. BROWNING. By Professor C. $\mathbf{H}$. HERFORD. 
MOIR, D. M.

LIFE OF MANSIE WAUCH, TAITOR IN DALKEITH. By D. M. MoIr. With Cruikshank's Illustrations. Cheaper Edition. Crown 8vo, 2s. 6d.

Another Edition. Illustrated cover, 1s. ; cloth, 1s. $6 \mathrm{~d}$.

MOMERIE, REV. ALFRED WIL= LIAMS, M.A., D.Sc., LL.D.

THE ORIGIN OF EVIL; AND OTHER Sermons. By Rev. Alfred Williams MoMeris, M.A., D.Sc., LL.D., late Fellow of St John's College, Cambridge. Eighth Edition, Enlarged. Crown 8vo, $5 \mathrm{~s}$.

PERSONALITY. The Beginning and End of Metaphysics, and a Necessary Assumption in all Positive Philosophy. Fifth Edition, Revised. Crown 8vo, 3s.

PREACHING AND HEARING; AND OTHER Sermons. Fourth Edition, Enlarged. Crown 8vo, 5s.

BELIEF IN GOD. Fourth Edition. Crown 8vo, 3s.

THE FUTURE OF RELIGION; AND oTHER Essays. Second Edition. Crown 8vo, 3s. 6d.

THE ENGLISH CHURCH AND THE ROMISH SCHISM. Second Edition. Crown 8vo, 2s. 6d.

ESSAYS ON THE BIBLE. Crown $8 \mathrm{vo}, 3 \mathrm{~s}$. 6 d. net.

CHARACTER. Crown 8vo, 3s. 6d. net.

MODERN SCEPTICISM AND MODERN FAITH. Crown 8vo, 3s. 6d. net.

MOMERIE, MRS.

DR ALFRED MOMERIE. His Life and Work. By Mrs MOMERIE. Demy svo, 12s. 6d. net.

MONTAGUE, E. R.

TALES FROM THE TALMUD. By E. R. Montague. Crown 8vo, 3s. 6d.

MORICE, REV. F. D.

PINDAR. (Ancient Classics for English Readers.) By Rev. F. D. MORICE. Fcap. 8vo, 1s. net.

MORISON, SIR THEODORE, K.C.I.E., and HUTCHINSON, GEORGE P.

LIFE OF SIR EDWARD FITZGERALD LAW, K.C.S.I., K.C.M.G. By Sir THEODORE MORISON, K.C.I.E., and George P. Hutchinson. Demy 8vo.

MUNRO, NEIL.

THE DAFT DAYS. By NeIL MUNRo. Third Impression. Crown 8vo, 6s. Uniform Edition, 3s. 6d. Cheap Edition, 1s. net.

FANCY FARM. Crown 8 vo, 6 s.
MUNRO, NEIL-contd.

Uniform Edition Novels.

JOHN SPLENDID. The Tale of a Poor Gentleman and the Little Wars of Lorn. Sixth Impression. Crown 8vo, 3s. 6d.

CHILDREN OF TEMPEST: A TALE OF THE OUTER ISLES. Crown $8 \mathrm{vo}, 3 \mathrm{~s} .6 \mathrm{~d}$.

SHOES OF FORTUNE. Crown 8vo, $3 \mathrm{~s} .6 \mathrm{~d}$.

THE IOST PIBROCH, AND OTHER SHEILING STORIES. Fourth Impression. Crown 8vo, 3s. 6d.

DOOM CASTLE: A Romance. Second Impression. Crown 8vo, 3s. 6d.

GILIAN THE DREAMER. Crown 8vo, 3s. 6d.

THE DAFT DAYS. Third Impression. Crown 8vo, 3s. $6 \mathrm{~d}$.

MUNRO, ROBERT, M.A., M.D., LL.D., F.R.S.E.

RAMBLES AND STUDIES IN BOSNIAHERZEGOVINA AND DALMATIA. By Robert Munro, M.A., M.D., L..D. F.R.S.E. Second Edition, Revised and Enlarged. With numerous Illustrations. Demy 8vo, 12s. 6d. net.

PREHISTORIC PROBLEMS. With numerous Illustrations. Demy $8 v 0$, 10s. net.

MUNRO, WILLIAM, M.A.

ON VALUATION OF PROPERTY By William Munro, M.A., Her Majesty's Assessor of Railways and Canals for Scotland. Second Edition, Revised and Enlarged. 8vo, 3s.6d.

MYRES, PROFESSOR JOHN L.

A MANUAL OF CLASSICAL GEO. GRAPHY. By Јонn L. MrRes, M.A., Professor of Ancient History, Oxford. Crown 8vo.

[In the press.

NEAVES, LORD.

GREEK ANTHOLOGY. (Ancient Classics for English Readers.) By Lord Neaves. Fcap. 8vo, 1s. net.

NEWBOLT, HENRY.

THE NEW' JUNE. By HenRy New Bolt. Third Impression. Crown 8vo, 6s.

NICHOL, PROFESSOR.

BACON. (Philosophical Classics for English Readers.) By Professor Nichol. Fcap. 8vo, Part I., Is. net; Part II., 1s. net.

NICHOLSON, PROFESSOR H. AL= LEYNE, and LYDEKKER, RICHARD, B.A.

A MANUAL OF PALAONTOLOGY, for the use of Students. With a General Introduction on the Principles of Palæontology. By Professor H. ALLEYNE NICHOLSON and RICHARD LYDEKKER, B.A. Third Edition, entirely Rewritten and greatly Enlarged. 2 vols. 8vo, \&3, 3s. 
NICOL, REV. THOMAS, D.D.

RECENT ARCHAOLOHY AND THE BIBLE. Being the Croall Lecture for 1898. By the Rev. Thomas Nicol, D.I., Professor of Divinity and Biblical Criticisin in the University of Aberleen; Author of 'Recent Explorations in Bible Lands.' Demy 8vo, 9s. net.

THE FOUR GOSPELS IN THE EARLIEST CHURCH HISTORY. Being the Baird Lecture for 1907. Crown 8vo, 7s. 6d. net.

\section{NISBET, JOHN D.CEc。}

THE FORESTER: A Practical TreatISE ON British Forkistry aNd ARBORICULTURE, FOR LANDOWNERS, LAND Agents, AND Foresters. By JoHn NisBer, D.CEc. In 2 volumes, royal Svo, with 285 lllustrations, 42s. net.

THE ELEMENTS OF BRITISH FORESTRY. A Handbook for Forest Apprentices. Crown $8 v 0$. [In the press.

\section{NOBILI, RICCARDO.}

A MODERN ANTIQUE: A FLORENTINE Story. By Riccardo Nobili. Crown $8 v 0,6$ s.

\section{NOBLE, EDWARD.}

WAVES OF FATE. By Edward Noble. Crown 8vo, 6s.

FISHERMAN'S GAT: A STORY OF THE Thames Estuary. Crown $8 v 0,6 s$.

NOYES, ALFRED.

DRAKE: AN ENGLish EPIC. By ALFred Noyes. Books I.-III. Crown 8 vo, $5 \mathrm{~s}$. net. Books IV.-XII. Crown 8vo, $6 \mathrm{~s}$. net.

The Complete Work in 1 vol. Crown 8vo, 7s. 6d. net.

FORTY SINGING SEAMEN. Second Impression. Crown $8 \mathrm{vo}, 5 \mathrm{~s}$. net.

THE ENCHANTED ISLAND, AND other Poems. Crown 8vo, 5s, net.

COLLECTED POEMS. 2 vols. Crown Svo, 10s. net. Vols. sold separately, 5 s. net. each.

"OLE LUK=OIE."

THE GREEN CURVE. By" OLE LUKOrE." Third Impression. Crown 8vo, 6s. Cheap Edition, 1s. net.

OLIPHANT, C. F.

ALFRED DE MUSSET. (Foreign Classics for English Readers.) By C. F. Oliphant. Feap. 8vo, 1s. net.

\section{OLIPHANT, LAURENCE.}

PICCADILLY. By LaURENCE Oliphant. With Illustrations by Richard Doyle. 4s. 6d. New Edition, 3s. 6d. Cheap Edition, boards, 2s. 6ri.
OLIPHANT, MRS.

ANNALS OF A PUBLISHING HOUSE. William Blackwood and his Sons; Their Magazine and Friends. By Mrs OLIPHANT. With Four Portraits. Third Edition. Demy 8vo. Vols. I. and II. $£ 2,2$ s.

A WIDOW'S TALE, AND OTHER STORIKS. With an Introdnctory Note by J. M. Barrie. Second Edition. Crawn 8vo, $6 \mathrm{~s}$.

KATIE STEWART, AND OTHER STORIEs. New Edition. Crown 8vo, cloth, 3s. fid. Illustrated Boards, 2s. 6d.

VALENTINE AND HIS BROTHER. New Edition. Crown 8vo, 3s. 6d.

SONS AND DAUGHTERS. Crown 8vo, 3s. $6 \mathrm{~d}$.

DANTE. (Foreign Classics for English Readers.) Fcap. 8vo, 1s. net.

CERVANTES. (Foreign Classics for English Readers.) Feap. 8vo, 1s. net.

THE PERPETUAL CURATE. Illustrated boards, 2s. ; cloth, 2s. 6 d.

JOHN: A Love SToRY. Illustrated boards, 2s. ; cloth, 2s. 6 d.

THE RECTOR and THE DOCTOR'S FAMILY. Illustrated cover, 1s. ; cloth, 1s. 6 d.

OLIPHANT, MRS, and TARVER, F. MOLIERE. (Foreign Classies for English Readers.) By Mrs OLIPHANT and F. TARVER. Fcap. Svo, 1s. net.

OMOND, T, $S$.

THE ROMANTIC TRIUMPH. "Periods of European Literature." By T. S. OMOND. Crown 8vo, 5s. net.

O'NEILL, MOIRA.

SONGS OF THE GLENS OF ANTRIM. By Molra O'Neill. Fourteenth Inipression. Crown 8vo, 3s. $6 \mathrm{~d}$.

OXENDEN, MAUD.

THE STORY OF ESTHER. By MAUD OXENDEN. Crown 8vo, 6s.

PAGE AND LAPWORTH.

INTER MEDIATE TEXT - BOOK OF GEOLOGY. By Professor LAPWorth. Founded on Dr Page's 'Introductory Text-Book of Geology.' Crown Svo, 5s. ADVANCED TEXT-BOOK OF GEOLOGY. New Edition. Reviser and Enlarged by Professor LAPWORTH. Crown 8vo. [In the press.

INTRODUCTORY TEXT-BOOK OF PHYSICAL GEOGRAPHY. Crown 8 vo, 2s. 6d.

PHYSICAL GEOGRAPHY EXAMINA. TOR. Crown 8vo, sewed, 9d. 
PATERSON, JOHN W., Ph.D.

A MANUAL OF AGRICUTURAI, BOTANY. From the German of Dr A. B. Frank, Professor in the Royal Agricultural College, Berlin. With over 100 Illustrations. Crown 8vo, 3s. 6d.

PATERSON, MARGARET.

PEGGOTS; OK, THE INDIAN CONTINGENT. By Margaret Paterson. Crown 8vo, $6 \mathrm{~s}$.

REALITY. Crown 8vo, $6 \mathrm{~s}$.

PATTISON, R. P. DUNN.

HISTORY OF THE 91sT ARGYLLSHIRE HIGHLANDERS. By R. P. Dunn Pattison. With Maps and Illustrations. Demy 4to, 42s. net.

PAUL, SIR JAMES BALFOUR.

HISTORY OF THE ROYAL COMPANY OF ARCHERS, THE QUEEN'S BODYGuard For Scotland. By Sir James Balfour PaUl, Advocate of the Scottish Bar. Crown 4to, with Portraits and other Illustrations. £2, $2 \mathrm{~s}$.

PEARSE, COLONEL.

MEMOIR OF THE LIFE AND MILITARY SERVICES OF VISCOUNT LAKE, Baron lake of Delhi and Laswaree, 1744-1808. By Colonel Hugh Pearse. With Portraits, \&c. Demy 8vo, 15s. net.

PEILE, PENTLAND.

CLANBRAE : A GOLFING IDYLL. By Pentland Peile. Crown 8vo, $6 \mathrm{~s}$.

THE BLUFFSHIRE COURIER. Crown $8 \mathrm{vo}, 6 \mathrm{~s}$.

PERIODS OF EUROPEAN LITERATURE. Edited by Professor SAINTs. BURY. For List of Vols., see $p, 32$.

\section{PHILOSOPHICAL CLASSICS FOR} ENGLISH READERS. Edited by Wrlliam Knight, LL.D., Professor of Moral Philosophy, University of St Andrews. Cheap Re-issue in Shilling Volumes net. For List of Vols., see p. 32.

PIELE, LIEUT.-COLONEL S. C. F. LAWN TENNIS AS A GAME OF SKILL. By Lieut.-Col. S. C. F. PIELE. Seventh Edition. Fcap. 8vo, 1s.

POLLOK, ROBERT, A.M.

THE COURSE OF TIME: A Poem. By Robert Pollok, A.M. New Edition. With Portrait. Fcap. 8vo, gilt top, $2 \mathrm{~s} .6 \mathrm{~d}$.

\section{PORTER, MARY BLACKWOOD.}

JOHN BLACKWOOD, EDITOR AND PUBLISHER. By MARY BLACK WOOD Porter. With Two Portraits and view of Strathtyrum. Demy 8vo, 21s.
POTTS, A. W., M.A., LL.D., and DARNELL, REV. C., M.A. AUDITUS FACILIORES. An Easy Latin Construing Book, with Vocabulary. By A. W. Potrs, M.A., LL.D., Late Head master of the Fettes College, Edinburgh, and sometime Fellow of $\mathrm{St}$ John's College, Cambridge; and the Rev. C. Darnell, M.A., Late Headmaster of Cargilfield Preparatory School, Edinburgh, and Scholar of Pembroke and Downing Colleges, Cambridge. 1s. 6 d. net.

PRESTON-THOMAS, H., C.B.

THE WORK AND PLAY OF A GOVERNMENT INSPECTOR. By Herbert Preston-Thomas, C.B. With a Preface by the Right Hon. ЈонN Burns, M.P. Demy Svo, 10s. 6d. net.

PRINGLE - PATTISON, A. SETH, LL. D., D.C.L.

SCOTTISH PHILOSOPHY. A Comparison of the Scottish and German Answers to Hume. Balfour Philosophical Lectures, University of Edinburgh. By A. Seth Pringle-Pattison, LL.D., D.C.L., Fellow of the British Academy, Professor of Logic and Metaphysics in Edinburgh University. Fourth Edition. Crown 8 vo, 58 .

MAN'S PLACE IN THE COSMOS, AND other Essays. Second Edition, Enlarged. Post $8 \mathrm{vo}, 6 \mathrm{~s}$. net.

TWO LECTURES ON THEISM. Delivered on the occasion of the Sesquicentennial Celebration of Princeton University. Crown 8vo, 2s. 6d.

THE PHILOSOPHICAL RADICALS, AND OTHER EsSAys, including Chapters reprinted on the Philosophy of Religion in Kant and Hegel. Crown 8vo, 6s. net.

PUBLIC GENERAL STATUTES AFFECTING SCOTLAND from 1707 to 1847 , with Chronological Table and Index. 3 vols. large $8 \mathrm{vo}$, $£ 3$, 3s. Also Published Annually, with General Index.

RANJITSINHJI, PRINCE.

THE JUBILEE BOOK OF CRICKET. By Prince RanjitsinhJ.

Popular Edition. With 107 full-page Illustrations. Sixth Edition. Large crown 8 vo, $6 \mathrm{~s}$.

REEVE, HENRY, C.B.

PETRARCH. (Foreign Classics for English Readers.) By Henry Reeve, C.B. Fcap. 8vo, 1s. net.

REYNARD, CAPTAIN F.

THE HISTORY OF THE NINTH LANCERS FROM 1715 to 1903 . By Captain F. ReYNard. Royal 8vo, 42s. net. 
RICHARDSON, MAJOR E. H.

WAR, POLICE, AND WATCH DOGS. By Major E. H. Richakdson. With Illustrations. Crown 8vo, 5s, net.

RIVETT-CARNAC, J. H., C.I.E. MANY MEMORIES OF LIFE IN INDIA, AT HOME, AND ABROAD. By J. H. Rivetr-Carnac, C.I.E. With Portraits. Second Impression. Demy 8 vo, 10s. 6d. net.

ROBERTSON, PROFESSOR CROOM. HOBBES. (Philosophical Classics for Euglish Readers.) By Professor Сroos ROBERTSON. Fcap. 8vo, 18. net.

ROBERTSON, JAMES, D.D.

EARLY RELIGIONS OF ISRAEL. New and Revised Edition. Crown \&vo.

[In the press.

THE POETRY AND THE RELIGION OF THE PSALMS. The Croall Lectures, 1893-94. By JAMES ROBKRTSON, D.D. Professor of Oriental Languages in the University of Glasgow. Demy $8 \mathrm{vo}$, 128.

ROBERTSON, JOHN G., Ph.D.

A HISTORY OF GERMAN LITERA. TURE, By JOHN G. ROBERTSON, Ph.D., Professor of German, University of London. Demy $8 \mathrm{vo}, 10 \mathrm{~s}$. 6d. net.

SCHILLER AFTER A CENTURY. Crown 8vo, 2s. 6d. net.

RONALDSHAY, EARL OF, M.P.

ON THE OUTSKIRTS OF EMPIRE IN ASIA. By the Earl OF RONaldshay. M.P. With numerous Illustrations and Maps. Royal 8vo, 21s. net.

SPORT AND POLITICS UNDER AN EASTERN SKY. With numerous Illustrations and Maps. Royal 8vo, 21s. net.

A WANDERING STUDENT IN THE FAR EAST. With Maps and 60 Illustrations. 2 vols. short demy $8 v 0,21 s$. net.

AN EASTERN MISCELLANY. Demy 8vo, 10s. 6d. net.

RUTHERFURD, J. H.

THE HISTORY OF THE LINLITH. GOW AND STIRLINGSHIRE HUNT. From 1775 to the present. By J. H. RUTHERFURD. With Illustrations. Demy 8vo, 25s. net.

RUTLAND, DUKE OF, G.C.B.

NOTES OF AN IRISH' TOUR IN 1846. By the Duke of Ruthand, G.C.B. (Lord John Manners). New Edition. Crown 8vo, 2s. 6 d.
RUTLAND, DUCHESS OF.

THE COLLECTED WRITINGS OF JANETTA, DUCHESS OF RUTLAND. By the DUCHESS OF RUTJ.AND (LADY Joun Manners). With Portrait and Illustrations. 2 vols. post $8 \mathrm{vo}, 15 \mathrm{~s}$. net.

IMPRESSIONS OF BAD-HOMBURG. Comprising a Short Account of the Women's Associations of Geruany under the Red Cross. Crown 8vo, 1s. 6d.

SOME PERSONAL RECOLLECTIONS of the Later Years of the Earl of Beacons field, K.G. Sixth Edition. bd.

SOME OF THE ADVANTAGES of Easily Accessible Reading and Recrea. tion Rooms and Free Libraries. With Remarks on Starting and Maintaining them. Second Edition. Crown 8vo, 18.

ENCOURAGING EXPERIENCES of Reading and Recreation Roonis, Aims of Guilds, Nottingliam Social Guide, Existing Institutions, \&c., \&c. Crown 8 vo, $1 \mathrm{~s}$.

\section{SAINTSBURY, PROFESSOR.}

A HISTORY OF CRITICISM AND LITERARY TASTE IN EUROPE. From the Earliest Texts to the Present Day. By Georae SaintsbukY, M.A. (Oxon.), Hon. LL. D. (Aberd.), Professor of Rhetoric and English Literature in the University of Edinburgh. In 3 vols. demy 8vo. Vol. I.-Classical and Mediæval Criticism. 16s. net. Vul. II. - Froin the Renaissance to the Decline of Eighteenth Century Orthodoxy. 20s. net. Vol. III. - Nineteenth Century. 20s. net.

MATTHEW ARNOLD. "Modern English Writers." Second Edition. Crown $8 \mathrm{vo}, 2 \mathrm{~s} .6 \mathrm{~d}$.

THE FLOURISHING OF ROMANCE AND THE RISE OF ALLEGORY (12th aNd 13th Centuries). "Perjods of European Literature." Crown 8vo, 5s. net.

THE EARLIER RENAISSANCE. "Periorls of European Literature." Crown 8vo, 5s, net.

THE LATER NINETEENTH CEN. TURY. "Periods of European Literature." Crown 8vo, 5s. net.

A HISTORY OF ENGLISH CRITIC. ISM. Demy 8vo, 7s. 6 d. net.

SALMON, ARTHUR L.

SONGS OF A HEART'S SURRENDER. Br Arthur L. Salmon. Crown 8vo, $2 s$.

LIFE OF LIFE, AND OTHER POEMS. Crown 8vo, 2s, $6 \mathrm{~d}$.

LYRICS AND VERSES. Crown 8vo, 2s. $6 \mathrm{~d}$. 
SALMON, ARTHUR L.-contd.

A BOOK OF VERSES. Crown 8vo, 2s. 6d. net.

WEST COUNTRY VERSES. Crown Svo, 3s. net.

A LITTLE BOOK OF SONGS. Feap. Svo, 2s. 6d. net.

A NEW BOOK OF VERSE. Fcap. 8 vo, 2s. 6d. net.

SCHOOL CATECHISM.

Issued by a CONFERENCE OF MFMBERS of the Reformed Churches in ScotLAND. $18 \mathrm{mo}, \frac{1}{2} \mathrm{~d}$.

" SCOLOPAX."

A BOOK OF THE SNIPE. By "Scolopax." Illustrated. Crown 8vo, 5s. net.

SCOTT, SIR J. GEORGE, K.C.I.E. CURSED LUCK. By Sir J. GEORaE Scotr, K.C.I.E. Crown 8vo, 3s. 6d.

\section{SCOTT, MICHAEL.}

TOM CRINGLE'S LOG. By Michael Scotr. New Edition. With 19 Fullpage Illustratious. Crown 8 vo, 3s. 6d. THE CRUISE OF THE MIDGE. Illustrated boards, 2s.; cloth, 2s. 6d.

\section{SCOTTISH TEXT SOCIETY PUBLI =} CATIONS. For List of Vols., see p. 29.

\section{SCOTTISH BANKERS MAGAZINE.}

The Journal of the Institute of Bankers in Scotland. Quarterly, 1s. net.

SCUDAMORE, CYRIL.

BELGIUM AND THE BELGIANS. By Crril Scudamore. With Illustrations. Square crown $8 \mathrm{vo}, 6 \mathrm{~s}$.

SELLAR, E. M.

RECOLLECTIONS AND IMPRESSIONS. By E. M. Sellar. With Eight Portraits. Fourth Impression. Demy $8 v 0,10 s$. 6 d. net.

\section{SELLAR, EDMUND.}

MUGGINS OF THE MODERN SIDE. By Edmund Sellar. Crown 8vo, 6s.

GLENTYRE. Crown $8 \mathrm{vo}, 6 \mathrm{~s}$.

WHERE EVERY PROSPECT PLEASES. Crown $8 v o, 6 s$.

SETH, JAMES, M.A.

A STUDY OF ETHICAL PRINCIPLES. By JaMes SETH, M.A., Professor of Moral Philosophy in the University of Edinburgh. Tenth Edition, Revised. Post 8vo, 7s. 6d.

\section{SHARPLEY, H.}

ARISTOPHANE8-PAX. Edited, with Introduction and Notes, by H. SHARPLEY. Demy 8vo, 12s. 6d. net.

\section{SHAW, WILLIAM.}

SECURITIES OVER MOVEABLES. Four Lectures delivered at the Request of the Society of Accountants in Edinburgh, the Institute of Accountants and Actuaries in Glasgow, and the Institute of Bankers in Scotland in 1902-3. Demy 8vo, 3s. 6d. net.

SHEEPSHANKS, RICHARD.

HECTOR AND ACHILLES: A TALE of Troy. Illustrated by J. FinNEMORE. Rendered into English after the Chronicle of Homer by RICHARD ShEepshanks. Square erown $8 \mathrm{vo}, 5 \mathrm{~s}$. net.

SIME, JAMES, M.A.

SCHILLER. (Foreign Classics for English Readers.) By James Sime, M.A. Fcap. 8vo, 1s, net.

SIMPSON, PROFESSOR J. Y., D.SC. SIDE-LIGHTS ON SIBERIA. Some Account of the Great Siberian Iron Road: The Prisons and Exile System. By Professor J. Y. Simpson, D.Sc. With numerous Illustrations and a Map. Demy 8 vo, 16s.

SIMPSON, VIOLET A.

IN FANĆ'S MIRROR. BY VIOLET A. Simpson. Crown $8 v 0,6 \mathrm{~s}$.

SINCLAIR, ISABEL G.

THE THISTLE AND FLEUR DE LYS. By Isabel G. Sinclair. Crown 8vo, 3s. net.

SKELTON, SIR JOHN, K.C.B.

THE HANDBOOK OF PUBLIO HEALTH. A New Edition. Revised by James Patten MacDougall, C.B., Advocate, Secretary to the Lncal Government Board for Scotland, Joint-Author of 'The Parish Conncil Guide for Scotland,' and ABIJah Murray, Chief Clerk of the Local Government Board for Sentland. $3 \mathrm{~s} .6 \mathrm{~d}$. net.

SKRINE, F. $H$.

FONTENOY, AND GREAT BRITAIN'S SHARE IN THE WAR OF THE AUSTRIAN Succession. By F. H. Skrine. With Map, Plans, and Illustrations. Demy 8 vo, 21s. net.

SLATER, FRANCIS CAREY.

FROM MIMOSA IAAND. BY FRANCIS Carty Slater. Crown 8vo, 3s.6d. net.

SMITH, PROFESSOR G. GREGORY.

THE TRANSITION PERIOD. "Periods of European Literature." By G. Gregory SMith, M.A. (Oxon.), Professor of English Literature, Belfast University. Crown 8vo, 5s. net.

SPECIMENS OF MIDDLE SCOTS. Post 8vo, 7ః. 6d. net. 
SNELL, F. J.

THE FOURTEENTH CENTURY. "Periods of European Literature." By F. J. Snelt. Crown 8vo, 5s. net.

"SON OF THE MARSHES, A."

WITHIN AN HOUR OF IONDON TOWN : AMONG WILD BIRDS AND THFIR

Haunts. Edited by J. A. OwEN. Cheap Uniform Edition. Crown 8vo, 3s. 6d.

WITH THE WOODLANDERS AND BY THE TIDE. Cheap Uniform Edition. Crowu 8vo, 3s. 6d.

ON SURREY HILLS. Cheap Uniform Edition. Crown 8vo, 3s, 6d.

ANNALS OF A FISHING VILLAGE. Cheap Uniform Edition. Crown 8vo, 3 s. 6 d.

SORLEY, PROF., Litt.D., LL.D.

THE ETHICS OF NATURALISM. By W. R. SORLEY, Litt.D., LL.D., Fellow of the British Academy, Fellow of Trinity College, Cambridge, Professor of Moral Philosophy, University of Cambridge. Second Edition. Crown svo, 6s.

RECENT TENDENCIES IN ETHICS. Crown $8 \mathrm{vo}, 2 \mathrm{~s}$. 6d. net.

SPROTT, GEORGE W., D.D.

THE WORSHIP AND OFFICES OF THE CHURCH OF SCOTLAND. By George W. Sprott, D.D. Crown 8 vo, 6s.

THE BOOK OF COMMON ORDER OF THE CHURCH OF SCOTLAND, Commonly known as JoH KNOX's LITURGY. With Historical Introduction and Illustrative Notes. Crown 8vo, 4s. 6 d. net.

- SCOTTISH LITURGIES OF THE REIGN OF JAMES VI. Edited with an Introduction and Notes. Crown Sro, 4s. net.

EUCHOLOGION. A Book of Common Order. Crown 8vo, 4s. 6d. net.

ST ANDREWS UNIVERSITY CALENDAR. Printed and Published for the Senatus Academicus. Crown Svo, 2s. 6d. net.

ST ANDREWS UNIVERSITY L.L.A. CALENDAR. Printed and Published

it for the Senatus Academicus. Crown sio, 1s.
STEEVENS, G. W.

THINGS SEEN: IMPRESSIONS OF MEN, Cities, ANd Books. By the late $G$. W. Steevens, Edited by G. S. Street. With a Memoir by W. E. HeNrey, and a Photogravure reproduction of Collier's Portrait. Memorial Edition. Crown $8 \mathrm{vo}, 6 \mathrm{~s}$.

FROM CAPETOWN TO LADYSMITH, and EGYPT IN 1898. Memorial Edition. Crown 8vo, 6s.

IN INDIA. With Map. Memorial Edition. Crown 8vo, 6s.

THE LAND OF THE DOLLAR. Memorial Edition. Crown 8vo, $6 \mathrm{~s}$.

GLIMPSES OF THREE NATIONS. Memorial Edition. Crown 8vo, 6s.

MONOLOGUES OF THE DEAD. Memorial Edition. Crown 8vo, 3s. 6d.

\section{STEPHENS.}

THE BOOK OF THE FARM; dealing exhaustively with every Branch of Agriculture. Edited by JAMES MacDONALD, F.R.S.E., Secretary of the Highland and Agricultural Society of Scotland. With over 700 Illustrations and Animal Portraits. In Six Divisional Volumes at 10s. 6d. each; or Three Volumes of over 500 pages each, price One Guinea per Volume. Each Volume sold separately.

LAND AND ITS EQUIPMENT. With 346 Illustrations and 8 Plans of Farm Buildings. Royal $8 \mathrm{vo}, 21 \mathrm{~s}$.

FARM CROPS. With 354 Illustrations. Royal 8vo, 21s.

FARM LIVE STOCK. With 77 Illustrations and 84 Animal Portraits. Royal $8 \mathrm{vo}, 21 \mathrm{~s}$.

STEVENSON, G. H.

THE SILVER SPOON. By G. H. Stevenson. Crown 8vo, 6s.

\section{STEWART, CHARLES.}

HAUD IMMEMOR. Reminiscences of Legal and Social Life in Edinburgh and London, 1850-1900. By Сharles STEWART. With 10 Photogravure Plates. Royal 8vo, 7s. 6d.

STEWART and CUFF.

PRACTICAL NURSING. By ISLA STEwart, Matron of St Bartholomew's Hospital, London; and Herbert E. CuFr, M.D., F.R.C.S., Medical Officer for General Purposes to the Metropolitan Asylums' Board, London; late Medical Superintendent, North-Eastern Fever Hospital, Tottenham, London. Revised by H. E. CurF ; assisted by B. Cutlek, Assistant Matron of St Bartholomew's Hospital. Third Edition. Crown 8 ro, 5s. net. Also in 2 volumes, earlı $3 \mathrm{~s}$. $6 \mathrm{~d}$. net. 
STODDART, ANNA M.

LIFE AND LETTEBS OF HANNAH E. PIPE. By Anna M. Stoddart. With Portraits and Iilustrations. Demy 8 vo, 15s. net.

STORMONTH, REV. JAMES.

DICTIONARY OF THE ENGLISH LANGuage, Pronodncing, EtymoLOGICAL, AND EXPLANATORY. By the Rev. JaMks Stormonth. Revised by the Rev. P. H. Phelp. Library Edition. New and Cheaper Edition, with Supplement. Imperial 8vo, handsomely bound in half morocco, 18s. net.

ETYMOLOGICAL AND PRONOUNCING DICTIONARY OF THE ENGLISH LANGUAGE. Including a very Copious Selection of Scientific Terms. For use in Schools and Colleges, and as a Book of General Reference. The Pronunciation carefully revised by the Rev. P. H. Phelp, M.A. Cantab. A New Edition. Edited by William Bayne. Crown 8vo, pp. 1082. 5s. net.

HANDY SCHUOL DICTIONARY, PRONOUNCING AND EXPLANATORY. Thoroughly Revised and Enlarged by WILLIAM BAYNe. 16mo, 7 d. net.

STRAIN, E. H.

A PROPHET'S REWARD. By E. H. Strain. Crown 8vo, 6s.

SWAYNE, G. C.

HERODOTUS. (Ancient Classies for English Readers.) By G. C. Swayne. Ficap. 8vo, 1s. net.

SYLLABUS OF RELIGIOUS INSTRUCTION FOR PUBLIC SCHOOLS.

Issued by a Conference of Members OF THE Reformed ChuRches in SCOTLAND. $18 \mathrm{mo}, 1 \mathrm{~d}$.

SYNGE, M. B.

THE STORY OF THE WORLD. By M. B. Synge, With Coloured Frontispieces and numerous Illustrations by E. M. Synge, A.R.E., and Maps. 2 vols., 3s. 6d. each net.

TABLE OF FEES FOR CONVEY=

ANCING, \&c. 4to. Roxburgh, 3s.6d.; sewed, 2s. 6d.

THACKERAY, MISS.

MADAME DE SEVIGNÉ. (Foreign Classics for English Readers.) By Miss ThaCkeray. Feap. $8 \mathrm{vo}$, 1s. net.

THEOBALD, FRED. V., M.A.(Cantab.)

A TEXT-BOOK OF AGRICULTURAL ZOOLOGY. By Fred. V. THEOBALd. With numerous Illustrations. Crown 8vo, 8s. 6d.
THOMSON, COLONEL ANSTRUTHER.

HISTORY OF THE FIFE LIGHT HORSE. By Colonel ANSTRUTHER TномsоN. With numerous Portraits. Small 4to, 21s. net.

THOMSON, DAVID.

HANDY BOOK OF THE FLOWERGARDEN. By DAVID ThOMSON. Crown 8vo, 5s.

\section{THOMSON, WILLIAM.}

A PRACTICAL TREATISE ON 'THE CULTIVATION OF THE GRAPE VINE. By William Thomson, Tweed Vineyards. Tenth Edition. 8vo, 5s.

THORBURN, S. S.

ASIATIC NEIGHBOURS. By S. S. Thorburn. With Two Maps. Demy 8 vo, 10s. 6d. net.

THE PUNJAB IN PEACE AND WAR. Demy 8 vo, 12s, 6 d. net.

INDIA'S SAINT AND THE VICEROY. A Novel. Crown 8vo, 6s.

\section{THURSTON, KATHERINE CECIL.}

THE CIRCLE. By KatheriNe Cecil ThuRston. Ninth Impression. Crown $8 \mathrm{vo}, 6 \mathrm{~s}$.

JOHN !CHIICOTE, M.P. Fifteenth Impression, crown 8vo, 6s. Cheap Edition, is. net.

THE MYSTICS. With Illustrations. Crown 8 vo, 3s. 6 d.

THE FLY ON THE WHEEL. Crown $8 \mathrm{vo}, 6 \mathrm{~s}$.

TIELE, PROFESSOR, Litt.D., \&c.

ELEMENTS OF THE SCIENCE OF RELIGION. Part I. - Morphological. Part II. - Ontological. Being the Gifford Lectures delivered before the University of Edinburgh in 1896-98. By C. P. TiEle, Theol.D., Litt.D. (Bonon.), Hon. M.R.A.S., \&c., Professor of the Science of Religion in the University of Leiden. In 2 vols, post Svo, 7s. 6d. net each.

TRANSACTIONS OF THE HIGH LAND AND AGRICULTURAL SOCIETY OF SCOTLAND. Published Annually, price 5s.

TRAVERS, GRAHAM (Margaret Todd, M.D.)

THE WAY OF ESCAPE. A Novel. By Graham Travers (Margaret Tociù, M.D.) Second Impression. Crown 8vo, 6s.

WINDYHAUGH. Fourth Edition. Crown $8 \mathrm{vo}, 6 \mathrm{~s}$.

FELLOW TRAVELLERS. Fourth Edition. Crown $8 \mathrm{vo}, 6 \mathrm{~s}$. 
TROLLOPE, ANTHONY.

CASAR. (Ancient Classics for English Readers.) By ANTHONY TroLlope. Fcap, 8vo, 1s. net.

TROLLOPE, HENRY M.

CORNEILLE AND RACINE. (Foreign Classies for English Readers.) By Henry M. Trollope. Fcap. 8vo, 1s. net.

TRUSCOTT, L. PARRY.

THE MARRIAGE OF AMINTA. By L. Parry Truscott. Crown 8vo, 6s.

TULLOCH, PRINCIPAL.

PASCAL. (Foreign Classics for English Readers.) By Principal TUllocH. Fcap. 8vo, 1s. net.

TURNER, STANLEY HORSFALL, M.A.

THE HISTORY OF LOCAL TAXATION IN SCOTLAND. By STANLEY Horsfall Turner, M.A. Crown 8vo, 5s. net.

TWEEDIE, MAJOR-GENERAL W., C.S.I.

THE ARABIAN HORSE: HIS COUNTRY AND People. By Major-General W. TwEedie, C.S.I., Bengal Staff Corps, for many years H.B.M.'s ConsulGeneral, Baghdad, and Political Resident for the Government of India in Turkish Arabia. In one vol. royal 4to, with Seven Coloured Plates and other Illustrations, and a Map of the Country. Large Paper Edition. Price £6, 6s. net.

VAUGHAN, PROFESSOR C. E.

THE ROMANTIC REVOLT. By Professor C. E. Vadghan. Crown 8vo, $5 \mathrm{~s}$. net.

VEITCH, PROFESSOR.

HA MILTON. (Philosophical Classics for English Readers.) By Professor Vertch. Fcap. 8vo, 1s. net.

VOYAGE OF THE "SCOTIA," THE. Being the Record of a Voyage of Exploration in Antarctic Seas. By Three of the StaFf. Demy 8vo, 21s. net.

WADDELL, REV. P. HATELY, D.D. ESSAYS ON FAITH. By Rev. P. HaTely WADDELL, D.D. Crown 8Vo, $3 \mathrm{~s} .6 \mathrm{~d}$.

THOUGHTS ON MODERN MYSTICISM. Crown 8vo, 3s. 6d.

WAKE, LUCY.

LADY WAKE'S REMINISCENCES. By LuCY WAKE. With Portraits and Illinstrations. Second Impression. Demy 8vo, 12s. 6d. net.
WALFORD, E.

JUVENAL. (Ancient Classies for Eng. lish Readers.) By E. WAlford. Fcap. 8vo, 1s. net.

WALLACE, PROFESSOR.

KANT. (Philosophical Classies for English Readers.) By Professor WaLLACE. Feap. 8vo, 1s. net.

WARREN, SAMUEL.

DIARY OF A LATE PHYSICIAN. By Samuel Warren. Cloth, 2s. 6d.; boards, 2s. ; paper cover, 1s.

NOW AND THEN. The Lily and the Bee. Intellectual and Moral Development of the Present Age. 4s. 6d.

WATSON, GILBERT.

THE SKIPPER. By GILBERT WATSON. Crown 8vo, 6s.

WATT, MACLEAN.

BY STILL WATERS. By MacleaN WATT. 1s. 6d.; leather, $2 \mathrm{~s}$.

WEIGALL, ARTHUR E. P.

TRAVEIS IN THE UPPER EGYPTIAN DESERTS. By ARThur E. P. Weigall. With numerous Illustrations. Crown 8vo, 7s. 6d. net.

THE LIFE AND TIMES OF AKHNATON, PHARAOH OF EGYPT. Illustrated. Crown 8vo, 10s. 6d. net.

THE TREASURY OF ANCIENT EGYPT. Chapters on Ancient Egyptian History and Archæology. With Illustrations. Denuy 8vo, 7s. 6d. net.

WENLEY, PROFESSOR, D.Sc., D.Phil.

ASPECTS OF PESSIMISM. By R. M. WENLEY, M.A., D.Sc., D.Phil., Professor of Philosophy in the University of Michigan, U.S.A. Crown 8vo, 6s.

WHIBLEY, CHARLES

THACKERAY. "Modern English Writers." By Charles Whibley. Crown 8vo, 2s. 6 d.

WILLIAM PITT. With Portraits and Caricatures. Crown 8vo, 6s. net.

AMERICAN SKETCHES. Crown 8vo, $6 \mathrm{~s}$.

WHISPER, A.

BLACK MARK, By A. WHISPER. Crown 8vo, 6s.

KING AND CAPTIVE. Crown 8vo, $6 \mathrm{~s}$.

THE SINISTFR NOTE. Crown 8vo, 6s.

WHITE, REV. JAMES.

SIR FRIZZLE PUMPKIN, NIGHTS AT MESS, \&C. By Rev. J AMES White. Illustrated cover, 1s. ; cluth, 1s. $6 \mathrm{~d}$. 
WHYTE, ADAM GOWANS.

THE TEMPLETON TRADITION. By Adam Cowans Whyte. Crown 8vo, 6 s.

WILSON, LADY.

LETTERS FROM INDIA. By LADY WiLsoN. Demy 8vo.

WILSON, PROFESSOR.

WORES' OF PROFESSOR WILSON. Edited by his Son-in-Law, Professor Frrrikr. 12 vols. crown 8vo, £2, 8s.

THE NOCTES AMBROSIAN A. 4 vols., $16 \mathrm{~s}$.

ESSAYS, Critical and Imaginative. 4 vols., $16 \mathrm{~s}$.

CHRISTOPHER IN HIS SPORTINGJACKET. 2 vols., 8s.

LIGHTS AND SHADOWS OF SCOT. TISH LIFE, AND OTHER TALES. $4 \mathrm{~s}$.

ISLE OF PALMS, CITY OF THE PLAGUE, AND OTher Pohms. $4 \mathrm{~s}$.

WINRAM, JAMES.

VIOLIN PLAYING and VIOLIN ADJUSTMENT. By JAMES WINRAM. Crown 8vo, 5s. net.
WORSLEY, PHILIP STANHOPE, M.A.

HOMER'S ODYSSEY. Translated into English Verse in the Spenserian Stanza. By Philip Stanhope Worsley, M.A. New and Cheaper Edition. Post 8vo, 7s. 6 d. net.

WOTHERSPOON, H. J., M.A.

KYRIE ELEISON "'LORD, HAVE Mercy"). A Manual of Private Prayers. With Notes and Additional Matter. By H. J. Wotherspoon, M.A., of St Oswald's, Edinburgh. Cloth, red edges, 1s. net; limp leather, 1s. 6d. net.

BEFORE AND AFTER. Being Part I. of 'Kyrie Eleison.' Cloth, limp, $6 \mathrm{~d}$. net.

THE SECOND PRAYER BOOK OF KING EDWARD THE SIXTH (1552), ALONG WITH THE LitURGy OF COMPROMIse. Edited by Rev. G. W. Sprotr, D.D. Crown 8vo, 4s, net.

YATE, LIEUT.-COLONEL, M.P.

KHURASAN AND SISTAN. By Lieut.Colonel C. E. YATE, C.S.I., C.M.G. With numerous Illustrations and Map. Demy 8vo, 218.

NORTHERN AFGHANISTAN; OR, LETTERS FROM THE ArGHAN BOUNDARY Commission. With Route Maps. Demy 8vo, $18 \mathrm{~s}$.

\section{BLACKWOODS'}

\section{Shilling Editions of Popular Novels.}

Bound in Cloth. With Coloured Illustration on Wrapper.

THE DAFT DAYS.

By Neil Munro.

THE LUNATIC AT LARGE.

By J. STORER Clouston.

CAPTAIN DESMOND, V.C.

By MaUd Diver.

THE GREAT AMULET.

By Maud Diver.

CANDLES IN THE WIND. By MaUd Diver.

[In June.

SARACINESCA.

By F. Marion Crawford.

THE MOON OF BATH.

By Beth Ellis.
JOHN CHILCOTE, M.P. By Katherine Cecil Thurston.

THE POWER OF THE KEYS. By Sydney C. Grier.

"PIP": A Romance of Youth. By IAN Hay.

THE RED NEIGHBOUR. By W. J. Ессотт.

THE GREEN CURVE. By Ole LUK-OiE.

THE RIGHT STUFF.

By IAN HaY. [In June. 


\section{The $\approx$ cottish $\tau$ ext $\cong 0$ cietr.}

THIS SocIETY was founded in 1882 for the purpose of printing and editing texts in Early and Middle Scots. Two parts or volumes, extending to not less than 400 pages, are published annually; but additional parts or volumes are issued when the funds permit. They are printed in uniform style, octavo, and are issued $(a)$ in paper covers, or (b) bound in half-leather (maroon), with cloth sides, gilt top, and gilt lettering. The Annual Subscription is $£ 1,1$ s. (One Guinea), payable in advance. Specimen Volumes may be seen at the Society's Printers, Messrs William Blackwood \& Sons, 45 George Street, Edinburgh, and 37 Paternoster Row, London, or in any of the libraries in Great Britain and abroad.

Note.-The volumes bave been issued in half-leather since 1897. Earlier volumes are in paper covers only ; but they may be bound to the Society's pattern at the cost of $1 \mathrm{~s} .6 \mathrm{~d}$. per volume. Most of the back volumes are in print, and may be purchased by subscribers. Particulars of price, \&c., may be had on application to the Treasurer.

\section{LIST OF PUBLICATIONS.}

The Kingis Quair, together with A Ballad of Good Counsel. By King James I. Edited by the Rev. Professor W. W. Skeat, M.A., LL.D. pp. 113 and $1 v$.

The Poems of William Dunbar. Part I. Edited by Jolnn Small, M.A. pp. 160 and iv.

The Court of Venus, By Iohne. Rolland, i575. Edited by the Rev. Walter Gregor, M.A., LL.D. pp. 231 and xxxii.

The Poems of William Dunbar. Part II. Edited by John Small, M.A. pp. 169 and vi.

Leslie's Historie of Scotland. Part I. Translated into Scottish from the original Latin by Father James Dalrymple. Edited by the Rev. E. G. Cody, O.S.B. pp. 130 and iv.

Schir William Wallace, Knight of Ellerslie. Part I. By Henry the Minstrel, commonly known as Blind Harry. Edited by James Moir, M.A. pp. 181.

The Wallace. Part II. Edited by James Moir, M.A. pp. 198.
Sir Tristrem. With Introduction, Notes, and Glossary. Edited by G. P. M'Neill, M.A. pp. 148 and xlviii.

The Poems of Alexander Montgomerie. Part I. Edited by James Cranstoun, M.A., LL.D. pp. 176 and vii.

The Poems of Alexander Montgomerie. Part II. Edited by James Cranstoun, M.A., LL.D. pp. 160 and iv.

The Poems of Alexander Montgomerie. Part III. Edited by James Cranstoun, M.A., LL.D. pp. 96 and lvii.

Gau's Richt Vay to the Kingdome of Heuine. Edited by the Rev. Professor Mitchell, D.D. pp. 130 and lviii.

Legends of the Saints (Fourteenth Century). Part I. Edited by the Rev. W. M. Metcalfe, M.A. pp. 224 and v.

Leslie's Historie of Scotland. Part II. Edited by the Rev. E. G. Cody, O.S.B. pp. 270 and xxvi.

Niniane Win3et's Works. Vol. I. Edited by the Rev. J. King Hewison. pp. 140 and $\mathrm{cxx}$. 
The Poems of William Dunbar. Part III. Introduction. By Æ. J. G. Mackay, LL.D. pp. celxxxiii.

The Wallace. Part III. Introduction, Notes, and Glossary. By James Moir, M.A. pp. 189 and liv.

Legends of the Saints. Part II. Edited by the Rev. W. M. Metcalfe, M.A. pp. 386 and iii.

Leslie's Historie of Scotland. Part III. Edited by the Rev. E. G. Cody, O.S.B. pp. 262 and iii.

Satirical Poems of the Time of the Reformation. Part I. Edited by James Cranstoun, M.A., LL.D. pp. 220 and vi.

The Poems of William Dunbar. Part IV. Containing the first portion of the Notes. By the Rev. W. Gregor, LL. D. pp. 244.

Niniane Win3et's Works. Vol. II. Notes and Glossary. By the Rev. J. King Hewison. pp. 203 and xxxiii.

Legends of the Saints. Part III. Edited by the Rev. W. M. Metcalfe, M.A. pp. 192 and iii.

Satirical Poems of the Time of the Reformation. Part II. Edited by James Cranstoun, M.A., LL.D. pp. 181 and lix.

Legends of the Saints. Part IV. Completing the Text. Edited by the Rev. W. M. Metcalfe, M.A. pp. 285 and iii.

The Vernacular Writings of George Buchanan. Edited by P. Hume Brown, M.A., LL.D. pp. 75 and $x \times x v i i i$.

Scottish Alliterative Poems in Riming Stanzas. Part I. Edited by F. J. Amours. pp. 187 and vi.

Satirical Poems of the Time of the Reformation. Part III. Containing first portion of Notes. By James Cranstoun, M.A., LL.D. pp. 188 and iii.

The Poems of William Dunbar. Part $\checkmark$. Completion of Notes and Glossary. By the Rev. W. Gregor, LL.D. And Appendix, by $\mathbb{E}$. J. G. Mackay, LL.D. pp. 291.

Satirical Poems of the Time of the Reformation. Part IV. Completion of Notes, Appendix, Glossary, and Index of Proper Names. By James Cranstoun, M.A., LL.D. pp. 186 and xii.

Barbour's Bruce. Part I. Edited by the Rev. Professor Walter W. Skeat, M.A., LL.D. pp. 351 and iii.
Barbour's Bruce. Part II. Edited by the Rev. Professor Walter W. Skeat, M.A. LL.D. pp. 430 and viii.

Barbour's Bruce. Part III. Introduction. By the Rev. Professor Walter W. Skeat, M.A., LI.D. pp. exi.

Leslie's Historie of Scotland. Edited by the Rev. E. G. Cody, O.S.B. Part IV. Completion of Text, with Notes, Glossary, \&c. By William Murison, M.A. pp. 328 and vii.

Legends of the Saints. Part V. Notes (first portion). By the Rev. W. M. Metcalfe, D.D. pp. 256 and iv.

The Poems of Alexander Scott. Edited by James Cranstoun, M.A., LL.D. pp. 218 and xxii.

Legends of the Saints. Part VI. Com pletion of Notes and Glossary. By the Rev. W. M. Metcalfe, D.D. pp. 240 and 1.

\section{Scottish Alliterative Poems in Riming} Stanzas. Part II. Edited by F. J. Amours. pp. 294 and xc.

The Gude and Godlie Ballatis. Edited by the Rev. Professor Mitchell, D.D. pp. 338 and cliv.

The Works of Mure of Rowallan. Vol. I. Edited by William Tough, M.A. pp. 306 and xxvii.

Works of Mure of Rowallan. Vol. II Edited by William Tough, M.A. pp. 345 and iii.

Lindesay of Pitscottie's Historie and Cronicles. Vol. I. Edited by Aneas J. G. Mackay, LL.D. pp. 414 and clx.

Lindesay of Pitscottie's 'Historie and Cronicles. Vol. II. Edited by Alneas J. G. Mackay, LL.D. pp. 478 and xii.

Gilbert of the Haye's Prose MS. (1456). Vol. 1. The Buke of the Law of Armys, or Butce of Bataillis. Edited by J. H. Stevenson. pp. 303 and cvii.

Catholic Tractates of the Sixteenth Century $(1573=1600)$. Edited by Thomas Graves Law, LL.D. pp. 308 and lxiii.

The New Testament in Scots, being Purvey's Revision of Wycliffe's Version, turned into Seots by Murdoch Nisbet (c. 1520). Edited by Thomas Graves Law, LL.D. Vol. I. pp. 300 and xxxvii.

Livy's History of Rome: The First Five Books. Translated 3 into Scots by John Bellenden (1533). Vol. I. Edited by W. A. Craigie, M.A. pp. 305 and xvii. 
The Poems of Alexander Hume (? I 557 1609). Edited by the Rev. Alexander Lawson, B.D. pp. 279 and Ixxiii.

The New Testament in Scots. Edited by Thomas Graves Law, LL.D. Vol. II. pp. 367 and ix.

The Original Chronicle of Andrew of Wyntoun (c. 1420). Printed on Parallel Pages from the Cottonian and Wemyss MSS., with the Variants of the other Texts. Edited by F. J. Amours. Vol. II. (Text, Vol. I.) pp. 351 and xix.

Livy's History of Rome: The First Five Books. Completion of Text, with Notes and Glossary. Edited by W. A. Craigie, M.A. Vol. II. pp. 408.

The New Testament in Scots. Edited by Thomas Graves Law, LL.D. Vol. III. pp. 397 and xiii.

The Original Chronicle of Andrew of Wyntoun. Edited by F. J. Amours. Vol. III. (Text, Vol. II.) pp. 497 and xiv.
The Original Chronicle of Andrew of Wyntoun. Edited by F. J. Amours. Vol. IV. (Text, Vol. III.) pp. 435 and xi.

The Poems of Robert Henryson. Edited by Professor G. Gregory Smith. Vol. II. (Text, Vol I.) pp. 327 and $x x i$.

The Original Chronicle of Andrew of Wyntoun. Edited by F. J. Amours. Vol. V. (Text, Vol. IV.) pp. 433 and $x i$.

The Original Chronicle of Andrew of Wyntoun. Edited by F. J. Amours. Vol. VI. (Text, Vol. V.) pp. 436 and $x v$.

The Poems of Robert Henryson. Edited by Professor G. Gregory Sinith. I Vol. III. (Text, Vol. II.) pp. 198 and xix.

Poems of Alexander Montgomerie, and other Pieces from Laing MS. No. 447. Supplementary Volume. Edited, with Introduction, Appendices, Notes, and Glossary, by George Stevenson, M.A. pp. 392 and $1 x v$.

\section{FORTHCOMING WORKS.}

Lindesay of Pitscottie's Historie and Cronicles. Vol. III. Glossary.

Gilbert of the Haye's Prose MS. (1459). Vol. II. The Buke of the Order of Chivalry, \&c. Edited by J. H. Stevenson, M.A.

The Vernacular Works of James VI. King of Scots. Edited by Oliphant Smeaton.

Specimens of Early Legal Documents in Scots. Edited by David Murray, LL.D.

The Maitland Folio MS. Edited by J. T. T. Brown. (See SERIES of MS. Collections.)

John of Ireland's Works (1490), from the MS. in the Advocates' Library.

Montgomerie's Poems, from the Laing MS. Edited by George Stevenson, M.A. [In the press.

The Makculloch and Gray MSS., with Excerpts from the Chepman and Myllar Prints. Edited by George Stevenson, M.A.

Catechisms of the Reformation. Edited by William Carruthers.
The Editorial Committee has other works under consideration, including-

The Buik of the Most Noble and Val= iant Conqueror Alexander the Grit. From the unique copy of Arbuthnot's print of 1580 , in the possession of the Earl of Dalhousie.

J. Stewart's Abbregement of Roland Furiovs, translait ovt of Ariost, togither vith svm rapsodies of the Author, \&c. From the dedication MS. copy presented to James VI., now preserved in the Advocates' Library.

Abacuk Bysset's 'Rolmentis of Courts' (1622), from the MS. in the Library of the University of Edinburgh (Laing Collection) and the MS. in the Advocates' Library.

The Poems of Gavin Douglas.

The Poems of Sir David Lyndsay. \&c. \&c.

And occasional Volumes of a Miscellany of Shorter Pieces. (Information regarding possible contributions will be gladly received by the Committee.) 


\section{PERIODS OF EUROPEAN LITERATURE: A Complete and}

Contindous History of the SUBJECT. Edited by Professur SAINTSBURY. In 12 crown 8 vo vols., each 5 s. net.

The Dark Ages. By Prof. W. P. Ker.

The Flourishing of Romance AND-THE Rise of Allegory. (12th and 13th Centuries.) By Prof. Saintsbury.

The Fourteenth Century. By F. J. Snell.

The Transition Period. By Prof. G. Gregory Smith.

The Earlier Renaissance. By Prof. Saintsbury.

The Later Renaissanck. By David Hannay.

\section{PHILOSOPHICAL CLASSICS} Edited by WILLIAM KNIGHT, in the University of St Andrews.

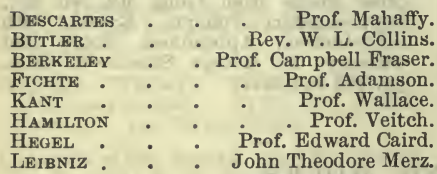

The First Half of the Seventeenth Century. By Prof. H. J. C. Grierson. The Augustan Ages. By Prof. Oliver Elton.

The Mid-Eightenth Century, By Prof. J. H. Millar.

The Romantic Revolt. By Prof. C. E. Vaughan.

The Romantic Triumph. By T. S. Omond. The Later Nineteenth Century. By Prof. Saintsbury.

\section{FOR ENGLISH READERS.}

LL.D., Professor of Moral Philosophy Re-issue in Shilling Volumes net.

Vico . . . . . Prof. Flint. HoBнes : Prof. Croom Robertson. HUME . . . . . Prof, Knight. SPINoza : : : Principal Caird. Bacon-Part I. . . . Prof. Nichol. BacON-Part II. : . : Prof. Nichol. LockE . . . Prof. Campbell Fraser.

FOREIGN CLASSICS FOR ENGLISH READERS. Edited by Mrs OLIPHANT. CheAP RE-1SSUe. In limp cloth, fcap. 8vo, price is. each net.

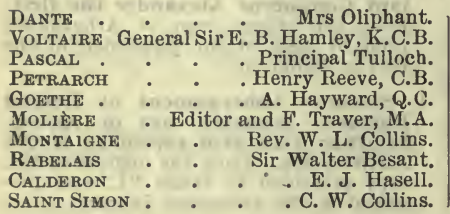

Cervantes . . Mrs Oliphant. Corneille and Racine Henry M. Trollope. MADAME DE Ś́vigNí . Miss Thackeray. LA Fontaine aNd other ) Rev. W. Lucas French Fabulists . Collins, M.A. Schiller . . James Sime, M.A. TAsso * . . . E. J. Hasell. Rousseau : : Henry Grey Graham. AlrREd de Musset - C. F. Oliphant.

\section{ANCIENT CLASSICS FOR ENGLISH READERS. Edited by} the Rev. W. LUCAS COLlinS, M.A. Cheap RE-ISSUe. In limp cloth, fcap. 8vo, price 1s. each net. Contents of the Series-

Homer: ILIAD . Rev. W. Iucas Collins. Homer: Odyssey . Rev. W. Lucas Collins. Herodotus

CFsar

G. C. Swayne.

VIRGIL

HoracE :

ASCHYLUS

XENOPHON

Cicero

SOPHOCLES

ev. Anthony Trollope.

Sir Theodore Martin.

- Bishop Copleston.

- Sir Alex. Grant.

C. W. Collins.

Pliny Rev. A. Church and W. J. Brodribb. EORIPIDWS W. B. Donne. JUVENAL E. Walford. aristophanes Rev. W. Lucas Collins. Hesiod and Theognis . . J. Davies.
Plautus and Terence Rev. W. L. Collins. Tacitus . . . . W. B. Donne. Lucian :- Rev. W. Lucas Collins. Plato : : . C. W. Collins. GreEK ANTHOLOGY : Lord Neaves. Livy . . Rev. W. Lueas Collins. OvID . . . Rev. A. Church. Catullus, Trbullus, and \} J. Davies. PeOpertius Demosthenes : : W. J. Brodribb. Aristotle . . . Sir Alex. Grant. ThuCydides . . Rev. W. Lucas Collins. LuCretius . . . W. H. Mallock. Pindar - $\quad$ Rev. F. D. Morice. 


\section{WM. BLACKWOOD \& SONS' EDUCATIONAL WORKS}

\section{CONTENTS.}

\begin{tabular}{|c|c|c|c|c|}
\hline & & & PAGE & \\
\hline ENGLISH . & & . & 35 & Palmontologi . \\
\hline History . & . & & 42 & Physical Geography \\
\hline Latin aND GRE & EEK & . & 43 & Psychology and Logic \\
\hline MODERN LANGU & DAGES & . & 50 & Forestrit \\
\hline Mathematios & . & . & 53 & ELEmentary SERIES \\
\hline GEOGRAPHY & - & $\cdot$ & 54 & Writing and Copy Book \\
\hline Chemistry aNd & Por & LAR & 55 & University CaLendars \\
\hline Geology & & , & 55 & \\
\hline
\end{tabular}




\section{EDUCATIONAL WORKS.}

\section{${ }_{* *}^{*}$ The Publishers will be glad to consider applications from Teachers for Specimen Copies.}

\section{ENGLISH.}

\section{A History of English Criticism.}

By George Saintsbury, M.A. (Oxon.), Hon. LL.D. (Aberd.), Professor of Rhetoric and English Literature in the University of Edinbnrgh. Demy 8 vo, 7s. 6 d. net.

\section{WORKS BY J. LOGIE ROBERTSON, M.A.}

\section{A History of English Literature.}

For Secondary Schools. By J. LoGie Robertson, M.A., First English Master, Edinburgh Ladies' College. With an Introduction by Professor MassoN, Edinburgh University. Fifth Edition, revised. 3s.

Daily Chronicle. - "The exposition is fresh and independent, and high above the level of the ordinary work of this class.......The book should prove a great boon not only to secondary schools and colleges but also to private students."

\section{Outlines of English Literature.}

For Young Scholars, with Illustrative Specimens. By the SAME AUTHOR. Second Edition, revised. 1s. 6d.

Spectator.- "To sketch English literature from Beowulf down to Lord Macaulay in a hundred and fifty pages without falling into the style of a catalogue, is an achievement of which Mr Robertson may well be proud."

\section{English Verse for Junior Classes.}

By the Same Author. In Two Parts. 1s. 6d. net each.

Part I.-Chaucer to Coleridge.

PART II.-Nineteenth-Century Poets.

School Guardian.- "Of the high literary quality of this selection there can be no question. There is nothing here that is not classical in the strictest sense of the word." 


\section{English Prose for Junior and Senior Classes.}

By the SAMr Author. In Two Parts. 2s. 6d. each.

PART I.-Malory to Johnson. | PART II.-Nineteenth Century.

Educational Times.- "We do not remember to have seen a better prose collection on the same scale, and the book should be very useful to teachers who like to work on the lines of genuine literature."

Mr R. Blair, Education Officer.- "I have to inform you that the Committee of the London County Council concerned have decided to add the book entitled 'English Exercises for Junior and Senior Classes' (J. L. Robertson, 1s.) to the Council's supplementary list of books for evening schools."

\section{English Exercises for Junior and Senior Classes.}

By the Same Author. 1s.

Schoolmaster. - "These exercises have the high recommendation of being the gradual growth of a course of practical work in an English class-room...... The manual cannot fail to be of service even to experienced teachers."

Headmaster, Council Central Secondary School._- "As an English teacher and lecturer of long experience, I may say unreservedly that I am delighted with the book. I shall certainly use it in my classes. The suggestions under each extract are extremely good, and will be valuable to teachers and students alike."

High School Headmaster._-"The exercises are admirably drawn up, and are most suitable for classes preparing for Leaving Certificate or University examinations. I have great pleasure in adopting the book as a class-book, and intend to use it systematically throughout the session."

\section{English Drama.}

By the Same Author. 2s. 6d.

Spectator. - "This capital selection....... Not only is it a text-book with excellent notes, but a neat and handy collection of English dramatic masterpieces."

\section{The Select Chaucer.}

Edited and Elucidated by the SAME AUTHor. Crown 8vo, 3s. ; and in Two Parts-Part I., 2s. ; Part II., 1s. 6d.

Athenæum.- "A very successful attempt to enlarge the range of Chaucer reading in schools. We wish we could believe that the book will have the circulation it deserves.".

\section{Paraphrasing, Analysis, and Correction of Sentences.}

By D. M. J. JAMES, M.A., Gordon Schools, Huntly. Is.

$$
\text { Also in Two Parts :- }
$$

Passages for Paraphrasing. Verse and Prose. 6d.

Exercises in Analysis, Parsing, and Correction of Sentences. $6 \mathrm{~d}$.

Athenæum. - "The pieces are well calculated to improve the grammar and style of the rising generation in an age which is not distinguished for lucidity or logic." 
Part I., Chaucer to Burns, cloth, Is. net. Part II., Wordsworth to Newbolt, cloth, 1s. net. In One Volume complete, cloth, $2 \mathrm{~s}$. net. Prize Edition, 5 s.

\title{
The
}

\section{School Anthology of English Verse.}

\section{A Selection of English Verse from Chaucer to the Present Day.}

\author{
EDITED BY \\ J. H. LOBBAN, M.A.,
}

Lecturer in English Literature, Birkbeck College, London;

Editor of 'The Granta Shakespeare,' \&c.

Athenæum.- "We have here such poetry as rings morally sound and exalts the soundest instincts and feelings of human nature."

Guardian. - "The work is worthy of nothing less than absolutely unqualified approval, and we cordially wish it the hearty welcome it deserves."

Journal of Education.- "One of the best small anthologies we have seen for some time. The selection is made with great good taste and care."

\section{Elementary Grammar and Composition.}

Based on the Analysis of Sentences. With a Chapter on Word-BumbING and Derivation, and containing numerous Exercises. 1s.

Schoolmaster.- "A very valuable book. It is constructive as well as analytic, and well-planned exercises have been framed to teach the young student how to use the elements of his mother-tongue."

\section{A Working Handbook of the Analysis of Sentences.}

With Notes on Parsing, Paraphrasing, Figures of Speech, and Prosody. New Edition, Revised. 1s. 6d.

Schoolmaster.- "The book deserves unstinted praise for the care with which the matter has been arranged, the depth of thought brought to bear upon the discussion of the subject....... One of the best and soundest productions on analysis of sentences we have met with yet." 


\section{STORMONTH'S ENGLISH DICTIONARIES,}

Pronodnoing, Etymological, and Explanatory.

\section{Library Edition.}

Imp. 8vo, half morocco, 18 s. net.

II. School and College Edition.

New Edition. Crown 8vo, 1080 pp. 5s. net.

\section{BLACKWOOD'S SEVENPEN N Y DICTIONARY}

"At such a price nothing better could be asked: good clear print, concise yet ample explanations, and accurate ety= mology. Just such a handy volume as schools need. Has evidently been prepared with great care. It justifies its record for reliability."-The School Guardian.

\section{STORMONTH'S \\ HANDY SCHOOL DICTIONARY}

PRONOUNCING AND EXPLANATORY

Thoroughly Revised and Enlarged by

WILLIAM BAYNE

\section{7d. net}




\section{The George Eliot Reader.}

By EuIzabeth LEE, Author of 'A School History of English Literature,' \&c. With an Introduction and Portrait. 2s.

Academy.- "A fascinating little volume."

\section{English Words and Sentences.}

BOOK I. FOR THE JUNIOR DIVISION. 6d.

Book II. FOR THE INTERmediate Division. $8 \mathrm{~d}$.

Practical Teacher.- "These books contain numerous well-graduated exercises in English, and should be popular with teachers of the subject."

Story of the World Readers. See p. 58.

\section{Blackwood's Literature Readers. See p. 57.}

\section{Specimens of Middle Scots.}

With Historical Introduction and Glossarial Notes. By G. Gregory Sмгтн, M.A., Professor of English Literature, University of Belfast. Crown 8 vo, 7s. 6d. net.

\section{English Prose Composition.}

By James Currie, LL.D. Fifty-seventh Thousand. 1s. 6 d.

\section{Short Stories for Composition.}

First Series. With Specimens of LetTers, and SUbJects for LetTers AND Essays. Seventh Impression. 112 pages. 1s.

\section{Short Stories for Composition.}

Second Series. With Lessons on Vocabulary. Third Edition. 112 pages. 1s.

Educational News. - "These stories are fresh, short, and pithy. They possess a novelty that will arrest attention, and a kernel that will tax to some measure the thinking faculty."

\section{Short Stories, Fables, and Pupil=Teacher Exercises for} Composition.

With Instructions in the Art of Letter and Essay Writing, Paraphrasing, Figures of Speech, \&c. 1s. 3 d.

\section{BLACKWOODS' SCHOOL SHAKESPEARE.}

Edited by R. BRImLex JoHnson. Each Play complete, with Introduction, Notes, and Glossary. In crown 8vo volumes. Cloth, 1s. 6d. ; paper covers, 1s. each.

The Merchant of Venice.

Richard II.

Julius Cæsar.

The Tempest.
As You Like It. Henry V. Macbeth. Twelfth Night.

Other Volumes in preparation. 


\section{BLACKWOODS' ENGLISH CLASSICS.}

With Portraits. In Fcap. 8vo volumes, cloth.

General Editor-J. H. LOBBAN, M.A.,

Editor of 'The School Anthology'; Lecturer in English Literature, Birkbeck College,

London; Editor of 'The Granta Shakespeare,' \&c.

Journal of Education.-" This Series has, we believe, already won the favourable notice of teachers. It certainly deserves to do so. Its volumes are edited with scholarly care and sound literary judgment. They are strongly and neatly bound, and extremely well printed."

Safurday Review.- "The print is good, and the introductions both short and to the point, while the notes strike a happy medium between misplaced erudition and trivial scrappiness."

school Board Chronic/e.- "There are no more thorough and helpful annotated editions than those of the series of Blackwoods' English Classics."

School Guardian.-" The editors have done their work carefully and well. The binding is neat and attractive, and the typography is of the excellent quality that we have learned to look for as a matter of course in Messrs Blackwoods' publications."

\section{Cowper-The Task, and Minor Poems.}

By Elizabetr Lek, Author of 'A School History of English Literature.' 2s. 6 d.

University Correspondent.- "Both the introduction and the notes are admirable. 'The edition can be safely recommended to all students."

Guardian. - "Miss Elizabeth Lee scores a distinct success. Her introduction is to the point and none too long; her notes are apt and adequate."

\section{Scott-Lady of the Lake.}

By W. E. W. Coluins, M.A. 1s. 6d.

Guardian.-"The introduction is particularly bright and interesting. The notes are brief, adequate, and to the point."

Saturday Review.- "Like some other members of this series of "English Classics' we have noticed recently, this volume is a good piece of work."

\section{Johnson-Lives of Milton and Addison.}

By Professor J. WIGHT DUFF, D.Litt., Durham College of Science, Newcastle-upon-Tyne. 2s, 6 d.

Educational News.- "A scholarly edition. The introduction contains things as good as are to be found in Macaulay's essay or Leslie Stephen's monograph."

\section{Milton-Paradise Lost, Books I. =IV.}

By J. Logie Robertson, M.A., First English Master, Edinburgh Ladies' College. 2s. $6 \mathrm{~d}$.

University Correspondent.-"The introduction and notes are more than satisfying."

Saturday Review.-_An excellent edition." 


\section{BLACKWOODS' ENGLISH CLASSICS-continued.}

\section{Macaulay-Life of Johnson.}

By D. Nichог Sмттн, M.A., Goldsmith's Reader in English, University of Oxford. 1s. 6d.

Journal of Education.- "Mr Smith's criticism is sound, simple, and clear. Annotated with care and good sense, the edition is decidedly satisfactory."

\section{Carlyle-Essay on Burns.}

By J. Downie, M.A., U.F.C. Training College, Aberdeen. 2s. 6d.

Guardian.- "A highly acceptable addition to our stock of school classics. We congratulate Mr Downie on having found a field worthy of his labours, and on having accomplished his task with faithfulness and skill."

\section{Goldsmith - Traveller, Deserted Village, and other Poems.}

By J. H. LobBan, M.A., Lecturer in English Literature, Birkbeck College, London. 1s. $6 \mathrm{~d}$.

Journal of Education. - "The notes are acceptable and well adapted to their purpose. We like the edition."

Literature.- "If Goldsmith touched nothing that he did not adorn, $\mathrm{Mr}$ Lobban and his publishers have adorned Goldsmith."

\section{Pope-Essay on Criticism, Rape of the Lock, and other Poems.}

By Grorge Soutar, M.A., Litt.D., Lecturer in English Language and Literature, University College, Dundee. 2s. 6d.

Guardian. - "The selection is made with taste, and the commentary is sound, adequate, and not overburdened with superfluous information."

\section{Hazlitt-Essays on Poetry.}

By D. Nichol SмIтH, M.A., Goldsmith's Reader in English, University of Oxford. 2s. $6 \mathrm{~d}$.

Athenæum. - "The introduction is a capital piece of work."

\section{Wordsworth, Coleridge, and Keats.}

By A. D. Innes, M.A., Editor of 'Julius Cæsar,' \&c., \&c. 2s. 6d. Academy.- "For Mr Innes's volume we have nothing but praise."

\section{Scott-Marmion.}

By Alexander Mackie, M.A., Examiner in English, University of Aberdeen ; Editor of 'Warren Hastings,' \&c. 1s. 6d.

Guardian. - "The volume is worthy to take its place with the best of its kind."

\section{Lamb-Select Essays.}

By Agnes Wilson, Editor of Browning's 'Strafford,' \&c. ; late Senior English Mistress, East Putney High School. 2s. 6d.

Athenæum.-- Miss Wilson's edition is well equipped." 


\section{BLACKWOODS' ENGLISH CLASSICS-continued.}

\section{Milton-Samson Agonistes.}

By E. H. Blakenke, M.A., Headmaster, King's School, Ely. 2s. 6d.

School World.-_"Everything testifies to excellent scholarship and editorial care....... The notes are a joy to the critic."

\section{Byron-Selections.}

By Professor J. WigHT DUFF, D.Litt., Armstrong College, in the University of Durham, Newcastle-upon-Tyne. 3s. $6 \mathrm{~d}$.

Academy and Literature.-_" Nothing has been done perfunctorily; Professor Duff is himself interested in Byron, and passes on to his reader, in consequence, some of the emotion he himself has felt."

Mr G. K. Chesterton in 'The Daily News.'-"Mr Wight Duff has made an exceedingly good selection from the poems of Byron, and added to them a clear and capable introductory study."

Professor R. Wülker in 'Englische Studien.'-"Wight Duff's Byron wird sicherlich dazu beitragen des Dichters Werke in England mehr zu verbreiten, als dies bisher geschehen ist. Aber auch in Deutschland ist das Buch allen Freunden Byron's warm zu empfehlen."

\section{HISTORY.}

\section{A Short History of Scotland.}

By ANDREw LANG. Crown 8vo, 5s. net.

[In the press.

\section{Stories of the English.}

By F. With Fifty Illustrations. Crown 8 vo, 3s. 6 d. net.

Scotsman.- "If history can be given a form likely to make it palatable to young folks, 'F.' has succeeded in doing so in these 'Stories of the English.' All that is revealed regarding the author's identity is that she is a woman, and the stories were written for a little girl born in Canada, and now resident in Ireland. The book begins with 'The Coming of the White Horse' (A.D. 449); it ends with Waterloo. In what might be described as a postscript, ' $\mathrm{F}$.' makes plain the moral which she has endeavoured to point in the preceding pages. It is no exaggeration to say that the book represents not only a masterpiece in literature for children, but a work of no slight value for the national good. It leads the child on and up through british history to a realisation of what citizenship of such an empire as Britain means. 'Stories of the English' should find a welcome in every household, and when the season of gifts comes round it should not be forgotten. Fifty striking illustrations conclude with the famous picture of Napoleon on board the Bellerophon." 


\section{LATIN AND GREEK.}

\section{Higher Latin Prose.}

With an Introduction by H. W. A UDEN, M.A., Principal, Upper Canada College, Toronto ; formerly Assistant-Master, Fettes College, Edinburgh ; late Scholar of Christ's College, Cambridge, and Bell University Scholar. 2s. 6 d.

$$
\text { ** A Key (for Teachers only), 5s. net. }
$$

Educational Times.-"Those who are in need of a short practical guide on the subject will find Mr Auden's little work well worth a trial.......The passages chosen are well suited for translation."

School Guardian.- "This is an excellent Latin prose manual. The hints on composition are first-rate, and should be of considerable use to the student of style who has mastered the ordinary rules of prose writing....... Altogether, this is a very valuable little book."

\section{Lower Latin Prose.}

By K. P. Wilson, M.A., Assistant-Master, Fettes College, Edinburgh. 2s. $6 \mathrm{~d}$.

$$
\text { * * A Key (for Teachers only), 5s. net. }
$$

Journal of Education.- "A well-arranged and helpful manual. The whole book is well printed and clear. We can unreservedly recommend the work."

\section{Higher Latin Unseens.}

For the Use of Higher Forms and University Students. Selected, with Introductory Hints on Translation, by H. W. A UDEN, M. A., Principal, Upper Canada College, Toronto ; formerly Assistant-Master, Fettes College, Edinburgh; late Scholar of Christ's College, Cambridge, and Bell University Scholar. 2s. 6d.

Educational News.- "The hints on translation given by $\mathrm{Mr}$ Auden are the most useful and judicious we have seen in such small bulk, and they are illustrated with skilful point and aptness."

Educational Review.- "Most practical and helpful introductory hints."

\section{Lower Latin Unseens.}

Selected, with Introduction, by W. LobBan, M.A., Classical Master, High School, Glasgow. 2s.

Athenæum.- "Varied in character and more interesting in substance than such things usually are."

Journal of Education.-- "A good selection of Latin Unseens, which will be welcomed by all teachers of Latin."

School Guardian.- "The introductory hints on translation should be well studied ; they are most valuable, and well put." 
Now issued at 1s. 6d. net to meet the requirements of the Education Department for a Latin Translation Book suited to pupils in the early stage of the subject. In its more expensive form the volume has been extensively used by the greater Public Schools, and is in its Twelfth Edition. A specimen copy will be sent gratis to any teacher wishing to examine the book with a view to introduction.

TWELFTH EDITION.

\title{
AdITUS FACILIORES. \\ AN EASY LATIN CONSTRUING BOOK, \\ WITH VOCABULARY. \\ BX
}

A. W. POTTS, M.A., LL.D.,

Late Head-Master of the Fettes College, Edinburgh, and sometime

Fellow of St John's College, Cambridge;

\author{
AND THE
}

REv. C. DARNELL, M.A.,

Late Head-Master of Cargilfield Preparatory School, Edinburgh, and Scholar of Pembroke and Downing Colleges, Cambridge.

\section{Contents.}

PART I.-Stories and Fables-The Wolf on his Death-Bed-Alexander and the Pirate-Zeno's Teaching-Ten Helpers-The Swallow and the Ants-Discontent-Pleasures of Country Life-The Wolf and the Lamb-Simplicity of Farm Life in Ancient Italy-The Conceited Jackdaw - The Ant and the Grasshopper - The Hares contemplate Suicide-The Clever Parrot-Simple Living-The Human Hand-The Bear-Value of Rivers-Love of the Country-Juno and the PeacockThe Camel-The Swallow and the Birds-The Boy and the Echo-The Stag and the Fountain-The Cat's Device-The Human Figure-The Silly Crow-Abraham's Death-Bed-The Frogs ask for a King-The Gods select severally a Favourite Tree-Hear the Other Side.

PART II.-Historical Extracts-The STORY of THE FABII : Historical Introduction-The Story of the Fabii. The CoNQUEST of VeII : Historical Introduction-The Conquest of Veii. THE SACrIfICE of Decius : Historical Introduction-The Sacrifice of Decius.

PART III.-The First Roman Invasion of Britain-Introduction to Extracts from Cæsar's Commentaries-The First Roman Invasion of Britain.

PART IV. - The Life of Alexander the Great-Historical Introduction-Life and Campaigns of Alexander the Great.

$$
\text { APPENDIX. Vocabulary. ADDENDA. }
$$

Two Maps to Illustrate the First Roman Invasion of Britain and the Campaigns of Alexander the Great. 


\section{First Latin Sentences and Prose.}

By K. P. Wirson, M.A., late Scholar of Pembroke College, Cambridge ; Assistant-Master at Fettes College. With Vocabulary. 2s, 6d. Also issued in Two Parts, 1s. 6d. each.

Saturday Review.- "This is just the right sort of help the beginner wants. ......It is certainly a book to be recommiended for preparatory schools or the lower classes of a public school."

Educational Review. - "Form masters in search of a new composition book will welcome this publication."

\section{A First Latin Reader.}

With Notes, Exercises, and Vocabulary. By K. P. Wilson, M.A., Fettes College. Crown 8vo, 1s. 6 d.

\section{Tales of Ancient Thessaly.}

An Elementary Latin Reading-Book, with Notes and Vocabulary. By J. W. E. Pearce, M.A., Headmaster of Merton Court Preparatory School, Sidcup; late Assistant-Master, University College School, London. With a Preface by J. L. Paton, M.A., late Fellow of St John's College, Cambridge; Headmaster of the Grammar School, Manchester. 1s.

Guardian.- "A striking and attractive volume. Altogether, we have here quite a noteworthy little venture, to which we wish all success."

\section{Latin Verse Unseens.}

By G. Mrdoleton, M.A., Classical Master, Aberdeen Grammar School, late Scholar of Emmanuel College, Cambridge ; Joint-Author of 'Student's Companion to Latin Authors.' 1s. 6d.

Schoolmaster.- 'They form excellent practice in 'unseen' work, in a great variety of style and subject. For purposes of general study and as practice for examinations the book is a thoroughly useful one."

Athenæum.- "These are well selected, and we are glad to see some of the lesser lights of Latin literature not omitted."

\section{Latin Historical Unseens.}

For Army Classes. By L. C. Vaughan Wrlkes, M.A. 2s.

Educational Times.- "Mr Wilkes has hit on a good idea, and has carried it out well. The teachers of army forms should certainly examine the book:"

Army and Nary Gazette.- "Will be found very useful by candidates for entrance to Sandhurst, Woolwich, and the Militia."

\section{Stonyhurst Latin Grammar.}

By Rev. John Grrard. Second Edition. Pp. 199. 3s.

\section{Aditus Faciliores Græci.}

An Easy Greek Construing Book, with Complete Vocabulary. By the late A. W. Potrs, M.A., LL.D., and the Rev. C. Darnrle, M.A. Fifth Edition. Fcap. 8vo, 3s. 


\section{Greek Accidence.}

For Use in Preparatory and Public Schools. By T. C. Wratherhead, M.A., Headmaster, Choir School, King's College, Cambridge; formerly of Trinity College, Cambridge, and Bell University Scholar. 1s. 6d.

Literature.- "Not the least of its merits is the clearness of the type, both Greek and English."

Pilot.- "The most useful book for beginners we have seen."

\section{The Messenian Wars.}

An Elementary Greek Reader. With Exercises and Full Vocabulary. By H. W. AUden, M.A., Principal, Upper Canada College, Toronto ; formerly Assistant-Master, Fettes College, Edinburgh ; late Scholar of Christ's College, Cambridge, and Bell University Scholar. 1s. $6 \mathrm{~d}$.

Saturday Review.- "A far more spirited narrative than the Anabasis. We warmly commend the book."

\section{Higher Greek Prose.}

With an Introduction by H. W. AUDEN, M.A., Principal, Upper Canada College, Toronto. 2s. 6d. ** Key (for Teachers only), 5s. net.

Guardian. - "The selection of passages for translation into Greek is certainly well made."

Journal of Education.-- "A manual of well-graduated exercises in Greek Prose Composition, ranging from short sentences to continuous pieces."

\section{Lower Greek Prose.}

By K. P. Wilson, M.A., Assistant-Master in Fettes College, Edinburgh.

2s. 6d. ** A Key (for Teachers only), 5s. net.

School Guardian. - "A well-arranged book, designed to meet the needs of middle forms in schools."

\section{Higher Greek Unseens.}

For the Use of Higher Forms and University Students. Selected, with Introductory Hints on Translation, by H. W. AuDEN, M.A., Principal, Upper Canada College, Toronto ; formerly Assistant-Master, Fettes College, Edinburgh. 2s. 6d.

Educational Times.- "It contains a good selection quite difficult enough for the highest forms of public schools.".

Schoolmaster. - "The introductory remarks on style and translation form eminently profitable preliminary reading for the earnest and diligent worker in the golden mine of classical scholarship."

\section{Greek Unseens.}

Being One Hundred Passages for Translation at Sight in Junior Classes. Selected and arranged. With Introduction by W. LOBBAN, M.A.,

Classical Master, The High School, Glasgow. 2s.

This little book is designed for the use of those preparing for the Leaving Certificate, Scotch Preliminary, London Matriculation, and similar examinations in Greek. The extracts are drawn from over a score of different authors, and regard has been had in the selection to literary or historical interest, and in the arrangement to progressive difficulty. 


\section{Greek Verse Unseens.}

By T. R. MILls, M.A., Lecturer in Classics, University College, Dundee, formerly Scholar of Wadham College, Oxford ; Joint-Author of 'Student's Companion to Latin Authors.' 1s. 6d.

School Guardian.-. "A capital selection made with much discretion....... It is a great merit that the selections are intelligible apart from their context."

University Correspondent.- "This careful and judicious selection should be found very useful in the higher forms of schools and in preparing for less advanced University examinations for Honours."

\section{Greek Test Papers.}

By JAMES MoIR, Litt.D., LL.D., late co-Rector of Aberdeen Grammar School. 2s. $6 \mathrm{~d}$.

$$
\text { * * A Key (for Teachers only), 5s. net. }
$$

University Correspondent.- "This useful book......The papers are based on the long experience of a practical teacher, and should prove extremely help. ful and suggestive to all teachers of Greek."

\section{Greek Prose Phrase Book.}

Based on Thucydides, Xenophon, Demostheres, and Plato. Arranged according to subjects, with Indexes. By H. W. AUDEN, M.A., Editor of 'Meissner's Latin Phrase Book.' Interleaved, 3s. 6d.

Spectator.- "A good piece of work, and likely to be useful."

Athenæum.- "A useful little volume, helpful to boys who are learning to write Greek prose."

Journal of Education.- "Of great service to schoolboys and schoolmasters alike. The idea of interleaving is especially commendable."

\section{Aristophanes-Pax.}

Edited, with Introduction and Notes, by H. SHARPLEY, M. A., late Scholar of Corpus Christi College, Oxford. In 1 vol. 12s. 6d. net.

\section{A Short History of the Ancient Greeks from the Earliest Times to the Roman Conquest.}

By P. Giles, Litt.D., LL.D., University Reader in Comparative Philology, Cambridge. With Maps and Illustrations.

[In preparation.

\section{Outlines of Greek History.}

By the SAME AUTHor. In 1 vol.

[In preparation.

\section{A Manual of Classical Geography.}

By John L. Mrres, M.A. Fellow of Magdalene College; Professor of Ancient History, Oxford.

[In preparation. 


\section{B LACKWOODS' \\ ILLUSTRATED \\ CLASSICAL TEXTS. \\ General Editor-H. W. AUDEN, M.A.,}

Principal of Upper Canada College, Toronto; formerly Assistant-Master at Fettes College; late Scholar of Christ's College, Cambridge, and Bell University Scholar.

Literature.- "The best we have seen of the new type of schoolbook."

Academy.- "If the price of this series is considered, we know not where to look for its equal."

Public School Magazine.-."The plates and maps seem to have been prepared regardless of cost. We wonder how it can all be done at the price."

\section{BLACKWOODS' CLASSICAL TEXTS.}

\section{Casar-Gallic War, Books I.-III.}

By J. M. HARDwich, M.A., Assistant-Master at Rugby; late Scholar of St John's College, Cambridge. With or without Vocabulary. 1s. 6d.

\section{Casar-Gallic War, Books IV., V.}

By Rev. St J. B. Wrnnk-Willson, M.A., Headmaster, Haileybury College ; late Scholar of St John's College, Cambridge. With or without Vocabulary, 1s. 6d. Vocabulary separately, $3 d$.

\section{Casar-Gallic War, Books VI., VII.}

By C. A. A. Do Ponter, M.A., Assistant-Master at Harrow. With or without Vocabulary. 1s. $6 \mathrm{~d}$.

\section{Virgil-Georgic I.}

By J. Sargradnt, M.A., Assistant-Master at Westminster ; late Scholar of University College, Oxford. 1s. 6d.

\section{Virgil-Georgic IV.}

By .J. Sargeadnt, M.A., Assistant-Master at Westminster ; late Scholar of University College, Oxford. 1s. 6d. 


\section{BLACKWOODS' CLASSICAL TEXTS-continued.}

\section{Virgil-Aneid, Books V., VI.}

By Rev. St J. B. Wynne Willson, M.A., Headmaster, Haileybury College. 1s. 6d.

\section{Ovid-Metamorphoses (Selections).}

By J. H. Vrnce, M.A., late Scholar of Christ's College, Cambridge; Assistant-Master at Bradfield. 1s. 6d.

\section{Ovid-Elegiac Extracts.}

By R. B. BURnabr, M.A. Oxon.; Classical Master, Trinity College, Glenalmond. 1s. $6 \mathrm{~d}$.

\section{Arrian-Anabasis, Books I., II.}

By H. W. AUden, M.A., late Scholar of Christ's College, Cambridge; Principal of Upper Canada College, Toronto; formerly Assistant-Master at Fettes College. 2s. 6d.

\section{Homer-Odyssey, Book VI.}

By E. E. Sikes, M.A., Fellow and Lecturer of St John's College, Cambridge. 1s. $6 \mathrm{~d}$.

\section{Homer-Odyssey, Book VII.}

By E. E. Sikes, M.A., Fellow and Lecturer of St John's College, Cambridge. [In preparation.

\section{Demosthenes-Olynthiacs, $I=3$.}

By H. Sharplex, M.A., late Scholar of Corpus College, Oxford ; AssistantMaster at Hereford School. 1s. 6d.

\section{Horace-Odes, Books I., II.}

By J. Sargeadnt, M.A., late Scholar of University College, Oxforil; Assistant-Master at Westminster. 1s. 6d.

\section{Horace-Odes, Books III., IV.}

By J. Sargeaunt, M.A., Assistant-Master at Westminster. 1s. 6d.

\section{Cicero-In Catilinam, I. -IV.}

By H. W. Auden, M.A., late Scholar of Christ's College, Cambridge ; Principal of Upper Canada College, Toronto; formerly Assistant-Master at Fettes College. 1s. 6d.

\section{Cicero-De Senectute and De Amicitia.}

By J. H. Vince, M. A., Assistant-Master at Bradfield.

\section{Cicero-Pro Lege Manilia and Pro Archia.}

[In preparation.

By K. P. WILson, M.A., late Scholar of Pembroke College, Ċambridge ; Assistant-Master at Fettes College. 2s. 6d. 


\section{BLACKWOODS' CLASSICAL TEXTS-continued.}

\section{Cicero-Select Letters.}

By Rev. T. Nickur, M.A., Assistant-Master at Rossall. 2s. 6 d.

\section{Cicero-Pro Caecina.}

By Rev. J. M. Lupton, M.A. Cantab., Assistant-Master at Marlborough College.

[In preparation.

\section{Tacitus-Agricola.}

By H. F. Morland Simpson, M.A., late Scholar of Pembroke College, Cambridge; Rector of Aberdeen Grammar School. [In preparation.

\section{Xenophon-Anabasis, Books I., II.}

By A. JAGGER, M.A., late Scholar of Pembroke College, Cambridge ; Headmaster, Queen Elizabeth's Grammar School, Mansfield. 1s. 6d.

\section{Sallust-Jugurtha.}

By I. F. SmedLey, M.A., Assistant-Master at Westminster; late Fellow of Pembroke College, Cambridge. 1s. $6 \mathrm{~d}$.

\section{Euripides-Hercules Furens.}

By E. H. Blakeney, M.A., Headmaster, King's School, Ely. 2s. 6d.

\section{Livy-Book XXVIII.}

By G. Mrddeeton, M.A., Classical Master in Aberdeen Grammar School; and Professor A. Souter, D.Litt., Yates Professor of New Testament Greek, Mansfield College, Oxford. 1s. 6d.

\section{Livy-Book IX.}

By J. A. Nicklin, B.A., late Scholar of St John's College, Cambridge; Assistant-Master at Liverpool College.

[In preparation.

\section{Nepos-Select Lives.}

By Rev. E. J. W. Houstron, D.D., Headmaster of Rossall School.

[In the press.

\section{MODERN LANGUAGES. FRENCH.}

\section{Historical Reader of Early French.}

Containing Passages Illustrative of the Growth of the French Language from the Earliest Times to the end of the 15th Century. By Herbert A. Strong, LL.D., Officier de l'Instruction Publique, Professor of Latin, University College, Liverpool ; and L. D. BARNETT, M.A., Litt.D. 3s.

Guardian.- "A most valuable companion to the modern handbooks on his. torical French grammar." 


\section{The Tutorial Handbook of French Composition.}

By AlFred Mercier, L. -ès-L., Lecturer on French Language and Literature in the University of St Andrews. 3s. 6d.

Educational Times. - "A very useful book, which admirably accomplishes its object of helping students preparing for examinations....... It is on rather novel lines, which commend themselves at once to any one who has had to teach the subject."

\section{French Historical Unseens.}

For Army Classes. By N. E. Toke, B.A. 2s. 6d.

Journal of Education.- "A distinctly good book....... May be unreservedly commended.'

\section{A First Book of "Free Composition" in French.}

By J. Edmond Mansion, B.-ès-L., Headmaster of Modern Language in the Royal Academical Institution, Belfast. 1s.

School World.-"We recommend it warmly to all teachers of French, and trust that it will have a wide circulation."

\section{French Test Papers for Civil Service and University Students.}

Edited by Emine B. LE Françors, French Tutor, Redeliff House, Winchester House, St Ives, \&c., Clifton, Bristol. 2s.

Weekly Register. - "Deserves as much praise as can be heaped on it...... Thoroughly good work throughout."

\section{All French Verbs in Twelve Hours (except Defective Verbs).}

By Alfred J. Wratt, M.A. 1s.

Weekly Register. - "Altogether unique among French grammatical helps, with a system, with a coup d'oeil, with avoidance of repetition, with a premium on intellectual study, which constitute a new departure."

\section{The Children's Guide to the French Language.}

By Annie G. Ferrier, Teacher of French in the Ladies' College, Queen Street, Edinburgh. 1s.

Schoolmaster.- "The method is good, and the book will be found helpful by those who have to teach French to small children."

\section{GERMAN.}

\section{A History of German Literature.}

By JoHn G. RoBertson, Ph.D., Professor of German in the University of London. 10s. 6 d. net.

Times.- "In such an enterprise even a tolerable approach to success is something of an achievement, and in regard to German literature Mr Robertson appears to have made a nearer approach than any other English writer."

\section{Outlines of German Literature.}

For the Use of Schools. By the Same Author.

[In preparation. 


\section{DR LUBOVIUS' GERMAN SERIES.}

\section{A Practical German Grammar, Reader and Writer.}

By Lours Lubovius, Ph.D., German Master, Hillhead High School, Glasgow ; Lecturer on German, U.F.C. Training College ; Examiner for Degrees in Arts, University of Glasgow. 3s. $6 \mathrm{~d}$.

Part I.-Elementary. 2s.

Part II. 3s.

\section{Lower Gierman.}

Reading, Supplementary Grammar with Exercises, and Material for Composition. With Notes and Vocabulary, and Ten Songs in Sol-Fa Notation. By Louis LuBovius, Ph.D. 2s. 6 d.

Athenæum.--"The volume is well designed."

Preparatory Schools Review._- "A capital reading-book for middle forms."

\section{Progressive German Composition.}

With copious Notes and Idioms, and FIRst Introduction to German Philology. By Louis Lubovius, Ph.D.

\section{Also in Two Parts :-}

Progressive German Composition. 2s. 6d.

** A Key (for Teachers only), 5s. net.

First Introduction to German Philology. 1s. $6 \mathrm{~d}$.

Journal of Education.- "The passages for translation are well selected, and the notes to the passages, as well as the grammatical introduction, give real assistance.......The part of the book dealing with German philology deserves great praise."

\section{A Compendious German Reader.}

Consisting of Historical Extracts, Specimens of German Literature, Lives of German Authors, an Outline of German History (1640-1890), Biographical and Historical Notes. Especially adapted for the use of Army Classes. By G. B. BEAK, M.A. 2s. 6d.

Guardian. - "This method of compilation is certainly an improvement on the hotch-potch of miscellaneous passages to be found in many of the older books."

\section{Spartanerjünglinge. A Story of Life in a Cadet College.}

By Padl von Szczepax́skr. Edited, with Vocabulary and Notes, by J. M. Morrison, M.A., Master in Modern Languages, Aberdeen Grammar School. 2s.

Scotsman.- "An admirable reader for teaching German on the new method, and is sure to prove popular both with students and with teachers."

\section{A German Reader for Technical Schools.}

By Ewald F. Seckler, Senior Language Master at the Birmingham Municipal Day School; German Lecturer, Birmingham Evening School ; French Lucturer, Stourbridge Technical School. 2s. 


\section{SPANISH.}

\section{A Spanish Grammar.}

With Copious Exercises in Translation and Composition; Easy reading

Lessons and Extracts from Spanish Authors; a List of Idioms; a Glossary of Commercial Terms (English-Spanish) ; and a copious General Vocabulary (Spanish-English). By William A. Kessex, Teacher of Spanish, Hillhead High School, Glasgow. 3s. 6d.

Investors' Review. - "To the student who wishes to master the Spanish language for commercial or literary purposes this admirable little book will prove invaluable."

Commerce.- "Contains practically all that is necessary for the acquirement of a working knowledge of the language."

\section{MATHEMATICS.}

\section{Arithmetic.}

With numerous Examples, Revision Tests, and Examination Papers. By A. Vertch Lothian, M.A., B.Sc., F.R.S.E., Mathematical and Science Lecturer, E.C. Training College, Glasgow. With Answers. 3s. 6d.

Guardian.- "A work of first-rate importance.......We should find it hard to suggest any improvement.......We venture to predict that when the book becomes known, it will command a very wide circulation in our public schools and elsewhere."

\section{Practical Arithmetical Exercises.}

For Senior Pupils in Schools. Containing upwards of 8000 Examples, consisting in great part of Problems, and 750 Extracts from Examination Papers. Second Edition, Revised. 364 pages, 3s. With Answers, 3s. 6d. JAMES /WeLTON, Esq., Lecturer on Education, and Master of Method, Yorkshire College.- "Your 'Practical Arithmetic' seems to me the most complete collection of exercises in existence. Both idea and execution are excellent."

\section{Elementary Algebra.}

The Complete Book, 288 pp., cloth, 2s. With Answers, 2s. 6d. Answers sold separately, price 9u. Pt. I., 64 pp., 6d. Pt. II., 64 pp., 6d. Pt. III., 70 pp., 6d. Pt. IV., 96 pp., 9d. Answers to Pts. I., II., III., each 2d. Answers to Pt. IV., 3d.

Educational News.- "A short and compact introduction to algebra....... The exercises are remarkably good, and the arrangement of the subject-matter is on the soundest principles. The work is, on the whole, to be commended as being at once inexpensive and scholarly."

\section{Handbook of Mental Arithmetic.}

With 7200 Examples and Answers. 264 pp. 2s. 6d. Also in Six Parts, limp cloth, price $6 \mathrm{~d}$. each.

Teachers' Monthly. - "The examples are mainly concrete, as they should be, are of all varieties, and, what is most important, of the right amount of difficulty."

Educational News.- "This is, as a matter of fact, at once a handbook and a handy book. It is an absolute storehouse of exercises in mental computations. ......There are most valuable practical hints to teachers." 


\section{Modern Geometry of the Point, Straight Line, and Circle.}

An Elementary Treatise. By J. A. THIRD, D.Sc., Headmaster of Spier's School, Beith. 3s.

Schoolmaster. - "Each branch of this wide subject is treated with brevity, it is true, and yet with amazing completeness considering the size of the volume. So earnest and reliable an effort deserves success."

Journal of Education. - "An exceedingly useful text-book, full enough for nearly every educational purpose, and yet not repellent by overloading."

Educational News. - "A book which will easily take rank among the best of its kind. The subject is treated with complete thoroughness and honesty."

\section{Mensuration.}

128 pp., cloth, 1s. Also in Two Parts. Pt. I., Parallelograms and Triangles. $64 \mathrm{pp}$. Paper, 4d.; cloth, 6d. Pt. II., Circles and Solids. $64 \mathrm{pp}$. Paper, 4d. ; cloth, 6d. Answers may be had separately, price $2 \mathrm{~d}$. each Part.

Educational Times.- "The explanations are always clear and to the point, while the exercises are so exceptionally numerous that a wide selection is offered to the students who make use of the book."

\section{Higher Arithmetic.}

For Ex-Standard and Continuation Classes. 128 pp. Paper, 6d. ; cloth, 8d. With Answers, cloth, 11d. Answers may be had separately, price 3d.

\section{GEOGRAPHY.}

\section{Fifty-Fifth Thousand.}

\section{Elements of Modern Geography.}

By the Rev. Alexander Mackat, LL.D., F.R.G.S. Revised to the present time. Pp. 300. 3s.

Schoolmaster. - "For senior pupils or pupil-teachers the book contains all that is desirable.......It is well got up, and bears the mark of much care in the authorship and editing."

\section{One Hundred and Ninety-Sixth Thousand.}

\section{Outlines of Modern Geography.}

By the Same Author. Revised to the present time. Pp. 128. 1s.

These 'Outlines'-in many respects an epitome of the 'Elements'-are carefully prepared to meet the wants of beginners. The arrangement is the same as in the Author's larger works.

\section{One Hundred and Fifth Thousand.}

\section{First Steps in Geography.}

By the Samk Author. 18mo, pp. 56. Sewed, 4d. ; in cloth, 6 d. 


\section{A Manual of Classical Geography.}

Ву Jонn L. Mrres, M.A., Professor of Ancient History, Oxford.

[In preparation.

\section{CHEMISTRY AND POPULAR SCIENCE.}

\section{Forty Elementary Lessons in Chemistry.}

By W. L. SarganT, M.A., Headmaster, Oakham School. Illustrated. 1s. $6 \mathrm{~d}$.

Glasgow Herald. - "Remarkably well arranged for teaching purposes, and shows the compiler to have a real grip of sound educational principles. The book is clearly written and aptly illustrated."

\section{Inorganic Tables, with Notes and Equations.}

By H. M. Trmpany, B.Sc., Science Master, Borough Technical School, Shrewsbury. Crown 8vo, 1s.

\section{Things of Everyday.}

A Popular Science Reader on Some Common Things. With Illustrations. 2s.

Guardian.- "Will be found useful by teachers in elementary and continuation schools who have to conduct classes in the 'science of common things.'......Well and strongly bound, and illustrated by beautifully clear diagrams."

\section{GEOLOGY.}

\section{An Intermediate Text-Book of Geology.}

By Professor Charles LAPWORTH, LL.D., University, Birmingham. Founded on Dr PAGE's 'Introductory Text-Book of Geology.' With Illustrations. $5 \mathrm{~s}$.

Educational News.- "The work is lucid and attractive, and will take high rank among the best text-books on the subject."

Publishers' Circular. - "The arrangement of the new book is in every way excellent, and it need hardly be said that it is thoroughly up to date in all details....... Simplicity and clearness in the book are as pronounced as its accuracy; and students and teachers alike will find it of lasting benefit to them."

Education. - "The name of the Author is a guarantee that the subject is effectively treated, and the information and views up to date."

\section{PALAEONTOLOGY.}

\section{A Manual of Palæontology.}

For the Use of Students. With a General Introduction on the Principles of Palæontology. By Professor H. Alleyne Nicholson, Aberdeen, and RICHARD LYDEKKER, B.A., F.G.S., \&c. Third Edition. Entirely rewritten and greatly enlarged. 2 vols. 8vo, with 1419 Engravings. 63s. 


\section{PHYSICAL GEOGRAPHY.}

Fifteenth Edition, Revised.

\section{Introductory Text-Book of Physical Geography.}

With Sketch-Maps and Illustrations. By DAvid PAGE, LL.D., \&c., Professor of Geology in the Durham College of Science, Newcastle. Revised by Professor Charles Lapworth. 2s.6d.

Athenæum.- "The divisions of the subject are so clearly defined, the explanations are so lucid, the relations of one portion of the subject to another are so satisfactorily shown, and, above all, the bearings of the allied sciences to Physical Geography are brought out with so much precision, that every reader will feel that difficulties have been removed, and the path of study smoothed before him."

\section{Examinations in Physical Geography.}

Adapted to the Text-Books of Physical Geography. By Professor PAGK. Sixth Edition. Sewed, 9d.

\section{PSYCHOLOGY AND LOGIC.}

\section{An Introductory Text=Book of Logic.}

With Numerous Examples and Exercises. By Sydnex Herbert Mellone; M.A. (Lond.), D.Sc. (Edin.); Examiner in Philosophy in the University of Edinburgh. Fourth Edition, Revised. Crown 8vo, 5s.

Scotsman. - "This is a well-studied academic text-book, in which the traditional doctrine that has been handed down from Aristotle to the university professors of to-day is expounded with clearness, and upon an instructive system which leads up naturally to the deeper and different speculations involved in modern logic.......The book, in fine, is an excellent working text-book of its subject, Yikely to prove useful both to students and to teachers."

\section{Elements of Psychology.}

By Sydney Herbert Mellone, M.A. (Lond.), D.Sc. (Edin.), and Markaret DRUMMOND, M.A. (Edin.) Crown 8vo, 5 s.

Scotsman.-- "Thoroughness is a feature of the work, and, treating psychology" as a living science, it will be found fresh, suggestive, and up-to-date."

Education. - "The authors of this volume have made satisfactory use of accredited authorities; in addition, they have pursued original investigations and conducted experiments, with the result that great freshness of treatment marks their contribution to the teaching of psychology."

\section{FORESTRY.}

\section{The Elements of British Forestry.}

A Handbook for Forest Apprentices. By JоHN NISBET, D.CE., Author of

'The Forester.' Crown 8vo. [in the press. 
"Absolutely the best set of all the history readers that have hitherto been published."-The Guardian.

\section{THE STORY OF THE WORLD.}

FOR THE CHILDREN OF THE BRITISH EMPIRE. (In Five Books.)

By M. B. SYNGE.

With Coloured Frontispieces and numerous IIlustrations by

E. M. Synge, A.R.E., and Maps.

BOOK I. ON THE SHORES OF THE GREAT SEA. 1s. 4d.

Colonial Edition, 1s. 6d.

THE Home of Abraham-Into AfricaJoseph in Egypt-The Children of IsraelThe First Merchant Fleet-Hiram, King of Tyre-King Solomon's Fleet-The Story of Carthage-The Story of the Argonauts-The Siege of Troy - The Adventures of UlyssesThe Dawn of History-The Fall of TyreThe Rise of Carthage-Hanno's Adventures -The Battle of Marathon-King Ahasuerus - How Leonidas kept the Pass-Some
Greek Colonies-Athens-The Death of Socrates-The Story of Romulus and Remus -HowHoratius kept the Bridge-Coriolanus -Alexander the Great-King of Macedonia - The Conquest of India - Alexander's City--The Roman Fleet-The Adventures of Hannibal - The End of Carthage - The Triumph of Rome-Julius Cæsar-The Flight of Pompey-The Death of Cæasar.

\section{BOOK II. THE DISCOVERY OF NEW WORLDS. 1s. 6 d.}

THE Roman World-The Tragedy of NeroThe Great Fire in Rome-The Destruction of Pompei-Marcus Aurelius-Christians to the Lions-A. New Rome-The Armies of the North-King Arthur and his Knights How the Northmen conquered EnglandThe First Crusade-Frederick BarbarossaThe Third Crusade-The Days of Chivalry - Queen of the Adriatic-The Story of Marco Polo - Dante's Great Poem - The
Maid of Orleans-Prince Henry, the SailorThe Invention of Printing-Vasco da Gama's Great Voyage - Golden Goa - Christopher Columbus-The Last of the Moors-Discovery of the New World-Columbus in Chains-Discovery of the Pacific-Magellan's Straits-Montezuma-Siege and Fall of Mexico - Conquest of Peru - A Great Awakening.

\section{BOOK III. THE AWAKENING OF EUROPE. 1s. 6d.}

\section{Colonial Edition, 1s, 9d.}

S'TORY of the Netherlands-The Story of Martin Luther-The Massacre of St Bartholomew-The Siege of Leyden-William the Silent - Drake's Voyage round the World-The Great Armada - Virginia-Story of the Revenge-Sir Walter Raleigh-The 'Fairy Queen'-First Voyage of the East India Company-Henry Hudson-Captain John Smith-The Founding of QuebecThe Pilgrim Fathers-Thirty Years of War -The Dutch at Sea-Van Riebeek's Colony
-Oliver Cromwell-Two Famous Admirals -De Ruyter-The Founder of Pennsyl. vania-The 'Pilgrim's Progress -William's Invitation-The Struggle in Ireland-The Siege of Vienna by the Turks-The Story of the Huguenots-The Battle of BlenheimHow Peter the Great learned Shipbuilding --Charles XII. of Sweden-The Boyhood of Frederick the Great-Anson's Voyage round the World-Maria Theresa-The Story of Scotland. 


\section{THE STORY OF THE WORLD—continued.}

BOOK IV. THE STRUGGLE FOR SEA POWER. 1s. 9d.

THE Story of the Great Mogul-Robert Clive-The Black Hole of Calcutta-The Struggle for North America-George Washington-How Pitt saved England-The Fall of Quebec-"The Great Lord Hawke"The Declaration of Independence-Captain Cook's Story-James Bruce and the NileThe Trial of Warren Hastings - Maria Antoinette - The Fall of the Bastile Napoleon Bonaparte-Horatio Nelson-The Adventures of Mungo Park-The Travels of Baron Humboldt-The Battle of the Nile-
Copenhagen - Napoleon - Trafalgar - The Death of Nelson-The Rise of WellingtonThe First Australian Colony-Story of the Slave Trade-The Defence of Saragoza-Sir John Moore at Corunna-The Victory of Talavera-The Peasant Hero of the TyrolThe "Shannon" and the "Chesapeake"Napoleon's Retreat from Moscow-Wellington's Victories in Spain-The Fall of the Empire-Story of the Steam Engine-Waterloo-The Exile of St Helena.

\section{BOOK V. GROWTH OF THE BRITISH EMPIRE. 2s.}

How Spain lost South America-The Greek War-Victoria, Queen of England-The Great Boer Trek-The Story of Natal-The Story of Canada-The Winning of the West -A Great Arctic Expedition-Discoveries in Australia-The Last King of France-Louis Kossuth and Hungary-The Crimean WarThe Indian Mutiny-King of United Italy -Civil War in America-The Mexican Revolution-Founding the German EmpireThe Franco-German War-The Dream of Cecil Rhodes - The Dutch Republics in
South Africa-Livingstone's discoveries in Central Africa-China's Long Sleep-Japan, Britain's Ally-Russia-The Annexation of Burma - The Story of Afghanistan - The Empire of India - Gordon, the Hero of Khartum-The Redemption of Egypt-The Story of British West Africa-The Story of Uganda - The Founding of Rhodesia British South Africa - The Dominion of Canada - Australia - The New Nation Freedom for Cuba-Reign of Queen Victoria -Welding the Empire-Citizenship.

Also in 2 volumes, at $3 \mathrm{~s}$. 6 d. each net, suitable as prize books.

Uniform with this Series.

\section{THE WORLD'S CHILDHOOD.}

With numerous Illustrations by Brinsley Le Fanu.

I. STORIES OF THE FAIRIES. IOd CONTENTS.

1. Lit-tle Red Ri-ding Hood.

2. The Three Bears.

3. The Snow-Child.

4. Tom Thumb.

5. The Ug-ly Duck-ling.

6. Puss in Boots.

7. The Lit-tle Girl and the Cats.

8. Jack and the Bean-Stalk.

9. Gol-dy.

10. Cin-der-el-la-Part I.
11. Cin-der-el-la-Part II.

12. The Lost Bell.

13. Jack the Gi-ant Kill-er.

14. Star-bright and Bird-ie.

15. Beau-ty and the Beast.

16. Peach-Dar-ling.

17. In Search of a Night's Rest.

18. Dick Whit-ting-ton and his Cat.

19. The Sleep-ing Beau-ty.

\section{STORIES OF THE GREEK GODS AND HEROES. Iod.}

1. A-bout the Gods.

2. The Names of the Gods.

3. Turn-ed in-to Stone.

4. The Shin-ing Char-i-ot.

5. The Laur-el Tree.

6. A Horse with Wings.

7. The Cy-press Tree.

8. The Fruits of the Earth.

9. Cu-pid's Gold-en Ar-rows.

10. Pan's Pipe.

11. A Long Sleep.

12. The Re-ward of Kind-ness.
13. At-a-lan-ta's Race.

14. The Stor-y of Al-ces-tis.

15. The Snow-White Bull.

16. The Spi-der and his Web

17. I-o-the White Cow.

18. The Three Gold-en Ap-ples.

19. The Ol-ive Tree.

20. A Boy Her-o of Old.

21. The Thread of Ar-i-ad-ne.

22. The Boy who tried to Fly.

23. The Gold-en Harp. Teacher's Appendix. 


\section{Standard Readers.}

Revised Edition. With Supplementary Pages, consisting of "Spelling Lists," "Word-Building," "Prefixes and Suffixes," \&c. Profusely Illustrated with Superior Engravings.

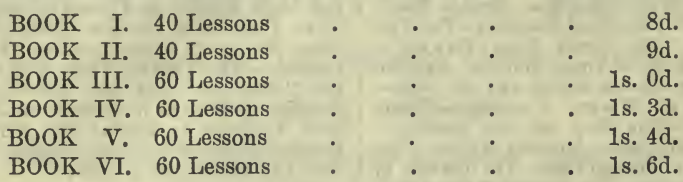

Schoolmaster.- "We strongly recommend these books.......Children will be sure to like them; the matter is extremely suitable and interesting, the print very distinct, and the paper a pleasure to feel."

\section{Infant Series.}

FIRST PICTURE PRIMER. - Sewed, 2d. ; cloth, 3d.

SECOND PICTURE PRIMER . . . Sewed, 2d.; cloth, 3d. PICTURE READING SHEETS.

1st Series. | 2ND Series.

Each containing 16 sheets, unmounted, 3s. $6 \mathrm{~d}$. Mounted on 8 boards, with cloth border, price 14s.; varnished, 3s. 6d. per set extra.

Or the 16 sheets laid on linen, varnished, and mounted on a roller, $17 \mathrm{~s} .6 \mathrm{~d}$.

THE INFANT PICTURE READER. With numerous Illustrations. Cloth, limp, 6d.

Educational News.- "Teachers will find these Primers a useful introduction to the art of reading. We consider them well adapted to their purpose."

\section{Geographical Readers.}

With numerous Maps, Diagrams, and Illustrations.

GEOGRAPHICAL PRIMER. (For Stand. I.) $96 \mathrm{pp} . \quad 9 \mathrm{~d}$.

BOOK I. (For Stand. II.) $96 \mathrm{pp.} . \quad$ 9d.

BOOK II. (For Stand. III.) $156 \mathrm{pp}$. . . 1s. 0 d.

BOOK III. (For Stand. IV.) $192 \mathrm{pp}$. . . 1s. 3d.

BOOK IV. (For Stand. V.) $256 \mathrm{pp}$. . . 1s. 6 d.

BOOK V. (For Stand. VI.) $256 \mathrm{pp}$. . . 1s. 6 d.

BOOK VI. (For Stand. VII.) $256 \mathrm{pp}$. . . 1s. $9 \mathrm{~d}$.

Schoolmaster. - "This is a really excellent series of Geographical Readers. The volumes have, in common, the attractiveness which good paper, clear type, effective woodcuts, and durable binding can present; whilst their contents, both as to quality and quantity, are so graded as to be admirably adapted to the several stages of the pupil's progress." 


\section{Historical Readers.}

With numerous Portraits, Maps, and other Illustrations. SHORT STORIES FROM ENGLISH HISTORY . . . . . . 160 pp. 1s. 0d. FIRST HISTORICAL READER - . . 160 pp. 1s. 0 d. SECOND HISTORICAL READER . . . 224 pp. 1s. 4d. THIRD HISTORICAL READER . . . 256 pp. 1s. $6 \mathrm{~d}$.

Schoolmaster. - "These new Historical Readers have been carefully compiled. The facts are well selected; the story is well told in language most likely to impress itself in the memory of young children; and the poetical pieces are fitting accompaniments to the prose."

School Board Chronicle.- "The treatment is unconventional, but always in good taste. The volumes will meet with much favour generally as lively, useful, high-toned Historical Readers."

\section{Standard Authors.}

Adapted for Schools.

HAWTHORNE'S TANGLEWOOD TALES. With Notes and Illustrations. $160 \mathrm{pp}$. $1 \mathrm{~s}, 2 \mathrm{~d}$.

\section{Aytoun's Lays of the Scottish Cavaliers.}

With Introduction, Notes, and Life of the Author, for Junior Classes.

EDINBURGH AFTER FLODDEN - 32 pages, 2d. ; cloth, $3 \frac{1}{2} \mathrm{~d}$.

THE EXECUTION OF MONTROSE - 32 pages, 2 d. ; cloth, $3 \frac{1}{2} \mathrm{~d}$.

THE BURIAL-MARCH OF DUNDEE 32 pages, $2 \mathrm{~d}$. ; cloth, $3 \frac{1}{2} \mathrm{~d}$.

THE ISLAND OF THE SCOTS . . 32 pages, $2 d$. cloth, $3 \frac{1}{2} \mathrm{~d}$.

Teachers" Aid. - "Capital annotated editions.......Beautifully clear and painstaking; we commend them heartily to our brother and sister teachers."

Educational News._- "Useful issues of well-known poems...... The notes are exceedingly appropriate, and leave nothing in doubt. For class purposes we can specially recommend these little books."

\section{School Recitation Books.}

$\begin{array}{lllllll}\text { BOOK I. } 32 \text { pages } & . & . & . & . & 2 \mathrm{~d} . \\ \text { BOOK II. } 32 \text { pages } & . & . & . & . & 2 \mathrm{~d} . \\ \text { BOOK III. } 48 \text { pages } & . & . & . & . & 3 \mathrm{~d} . \\ \text { BOOK IV. } 48 \text { pages } & . & . & . & . & 3 \mathrm{~d} . \\ \text { BOOK } \text { V. } 64 \text { pages } & . & . & . & . & 4 \mathrm{~d} . \\ \text { BOOK VI. } 64 \text { pages } & . & . & . & . & 4 \mathrm{~d} .\end{array}$

Schoolmistress.- "These six books are a valuable contribution to school literature. The poems for each standard are judiciously chosen, the explanatory notes and questions at the end of every lesson are very suitable." 


\section{Grammar and Analysis.}

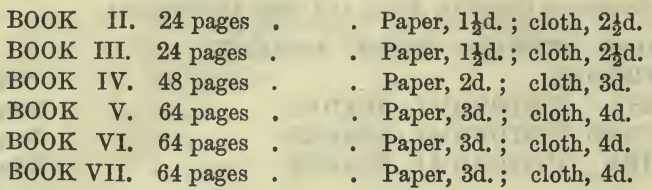

Schoolmaster. - "This is a series of good practical books whose merits ought to ensure for them a wide sale. Among their leading merits are simplicity in definitions, judicious recapitulation, and abundance of well-selected exercises for practice."

Teachers' Aid.-_"For thoroughness, method, style, and high-class work, commend us to these little text-books.......A practical hand has impressed every line with individuality....... We are determined to use them in our own department."

\section{Arithmetical Exercises.}

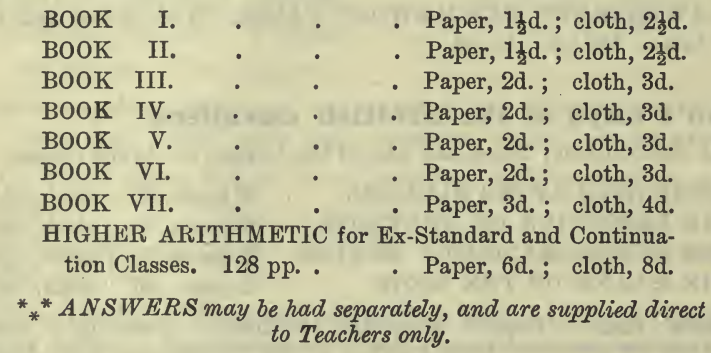

Schoolmaster. - "We can speak in terms of high praise respecting this series of Arithmetical Exercises. They have been carefully constructed. They are well graduated, and contain a large and varied collection of examples.......We can recommend the series to our readers."

Schoolmistress. - "Large quantity, excellent quality, great variety, and good arrangement are the characteristics of this set of Arithmetical Exercises."

\section{Elementary Grammar and Composition.}

Based on the ANalysis of Sennences. With a Chapter on Word-BuIlding and Derivation, and containing numerous Exercises. New Edition. 1s.

Schoolmaster.-"A very valuable book. It is constructive as well as analytic, and well-planned exercises have been framed to teach the young student how to use the elements of his mother-tongue.......A junior text-book that is calculated to yield most satisfactory results."

Educational Times.- "The plan ought to work well.......A decided advance from the old-fashioned practice of teaching." 


\section{Grammar and Analysis.}

Scotch Code.

STANDARD II. 24 pages. Paper, $1 \frac{1}{2} \mathrm{~d}$. ; cloth, $2 \frac{1}{2} \mathrm{~d}$.

STANDARD III. 32 pages. Paper, $1 \frac{1}{2} \mathrm{~d}$. ; cloth, $2 \frac{1}{2} \mathrm{~d}$.

STA NDARD IV. 56 pages. Paper, $2 \frac{1}{2} \mathrm{~d}$. ; cloth, $3 \frac{1}{2} \mathrm{~d}$.

STANDARD V. 56 pages. Paper, $2 \frac{1}{2} \mathrm{~d}$. ; cloth, $3 \frac{1}{2} \mathrm{~d}$.

STANDARD VI. 64 pages. Paper, 3d. ; cloth, 4d.

Teachers' Aid.- "These are thoughtfully written and very practically con. ceived little helps.......They are most exhaustive, and brimming with examples."

\section{New Arithmetical Exercises.}

Scotch Code.

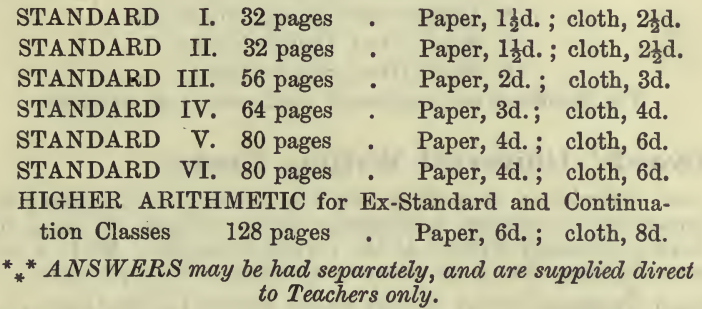

Educational News.- "The gradation of the exercises is perfect, and the examples, which are very numerous, are of every conceivable variety. There is ample choice for the teacher under every head. We recommend the series as excellent School Arithmetics."

\section{Merit Certificate Arithmetic.}

96 pp. Paper cover, 6d. ; cloth, 8d.

\section{Mensuration.}

128 pp., cloth, 1s. Also in Two Parts. Pt. I., Parallelograms and Triangles. 64 pp. Paper, 4d. ; cloth, 6d. Pt. II., Circles and Solids. 64 pp. Paper, 4d.; cloth, 6d. Answers may he had separately, price 2d. each Part.

Educational Times.- "The explanations are always clear and to the point, while the exercises are so exceptionally numerous that a wide selection is offered to the students who make use of the book."

\section{A First Book on Physical Geography.}

For Use in Schools. 64 pp. $4 \mathrm{~d}$.

Journal of Education.- "This is a capital little book, describing shortly and clearly the geographical phenomena of nature." 
Manual Instruction-Woodwork. Designed to MEeT the Requirements of the Minute of the Science and ARt Department on MANUAL Instruction. By GEORGE ST JOHN, Undenominational School, Handsworth, Birmingham. With 100 Illustrations. 1s.

\section{Blackwoods' Simplex Civil Service Copy Books.}

By John T. Pearce, B.A., Leith Academy. Price 2d. each.

CONTENTS OF THE SERIES.

No. 1. Elements, Short Letters, Words.

" 2. Long Letters, Easy Words.

3. Capitals, Half-line Words.

4. Text, Double Ruling, Sentences.

5. Half-Text, Sentences, Figures.

6. Intermediate, Transcription, \&c.

7. Small Hand, Double Ruling.

1. Small Hand, Single Ruling.

The Headlines are graduated, up-to-date, and attractive.

\section{Blackwoods' Universal Writing Books.}

Have been designed to accompany the above series, and teachers will find it advantageous to use them as Dictation Copies, because by them the learner is kept continually writing at the correct slope, \&c. No 1. is adapted for Lowrr Classes, No. 2 for Higher Classes. Price 2d. each.

Practical Teacher.- "Our readers would do well to write for a specimen of this book, and of the blank exercise-books ruled on the same principle. They are worth careful attention."

School World.- "Those teachers who are anxious to train their pupils to write in the style associated with Civil Service Competitions should find the copy-books designed by $\mathrm{Mr}$ Pearce very useful. The writing is certainly simple ; it may, in fact, be reduced to four elements, in which the pupil is rigorously exercised in the earlier books before proceeding in later numbers to continuous writing."

Schoolmaster.- "Those of our readers in search of new books should see these."

Journal of Education.- "Aids the eye and guides the hand, and thus checkmates any bias towards error in the slope."

\section{UNIVERSITY CALENDARS.}

\section{St Andrews University Calendar.}

Printed and Published for the Senatus Academicus. C'rown 8vo, 2s. 6d. net.

St Andrews University L. L.A. Calendar.

Printed and Published for the Senatus Academicus. Crown 8vo, 1s.

WILLIAM BLACKWOOD \& SONS, EDINBURGH AND LONDON. 
(w) 


\section{UNIVERSITY OF CALIFORNIA LIBRARY BERKELEY}

Return to desk from which borrowed.

This book is DUE on the last date stamped below.

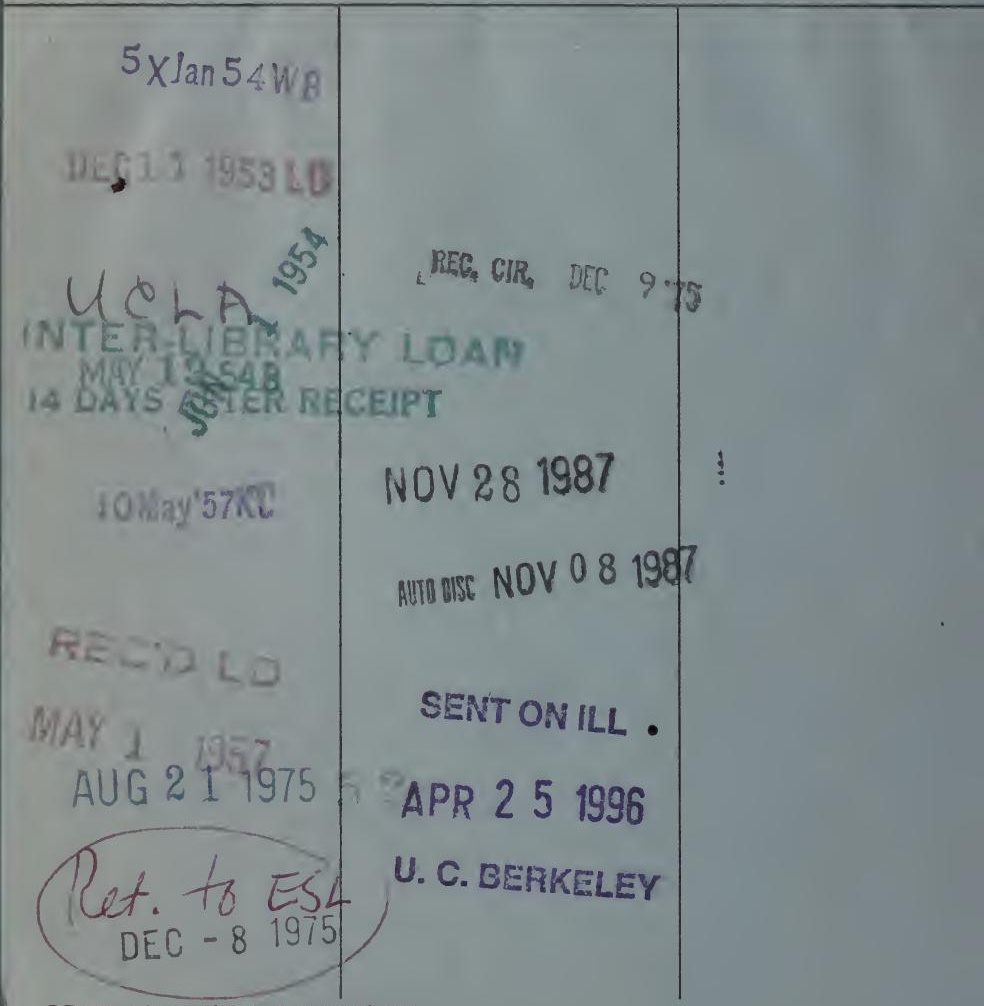

LD 21-100m-7,'52(A2528s16)476 


\title{
YB 15950
}

\section{U.C. BERKELEY LIBRARIES}

\author{
||||||||||||||||||||||||||||||||||||||||||||-1) \\ c004064691
}


다를

Non

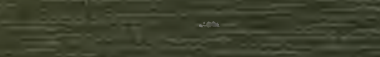

$x^{2}=0$

ans

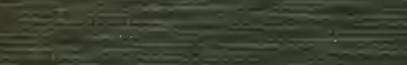

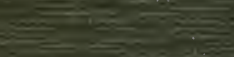

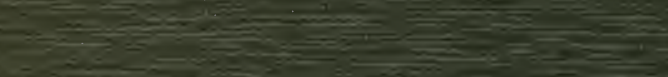

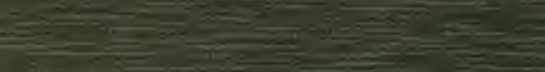

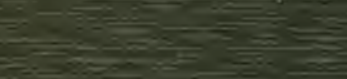

:

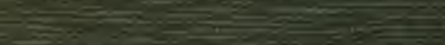

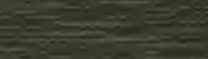

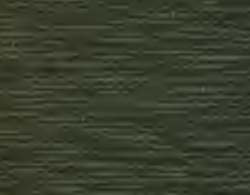

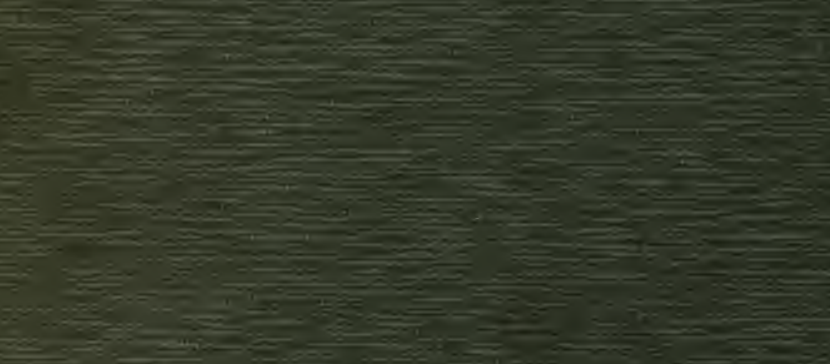

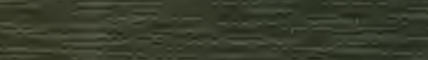

